Historic, Archive Document

Do not assume content reflects current scientific knowledge, policies, or practices. 



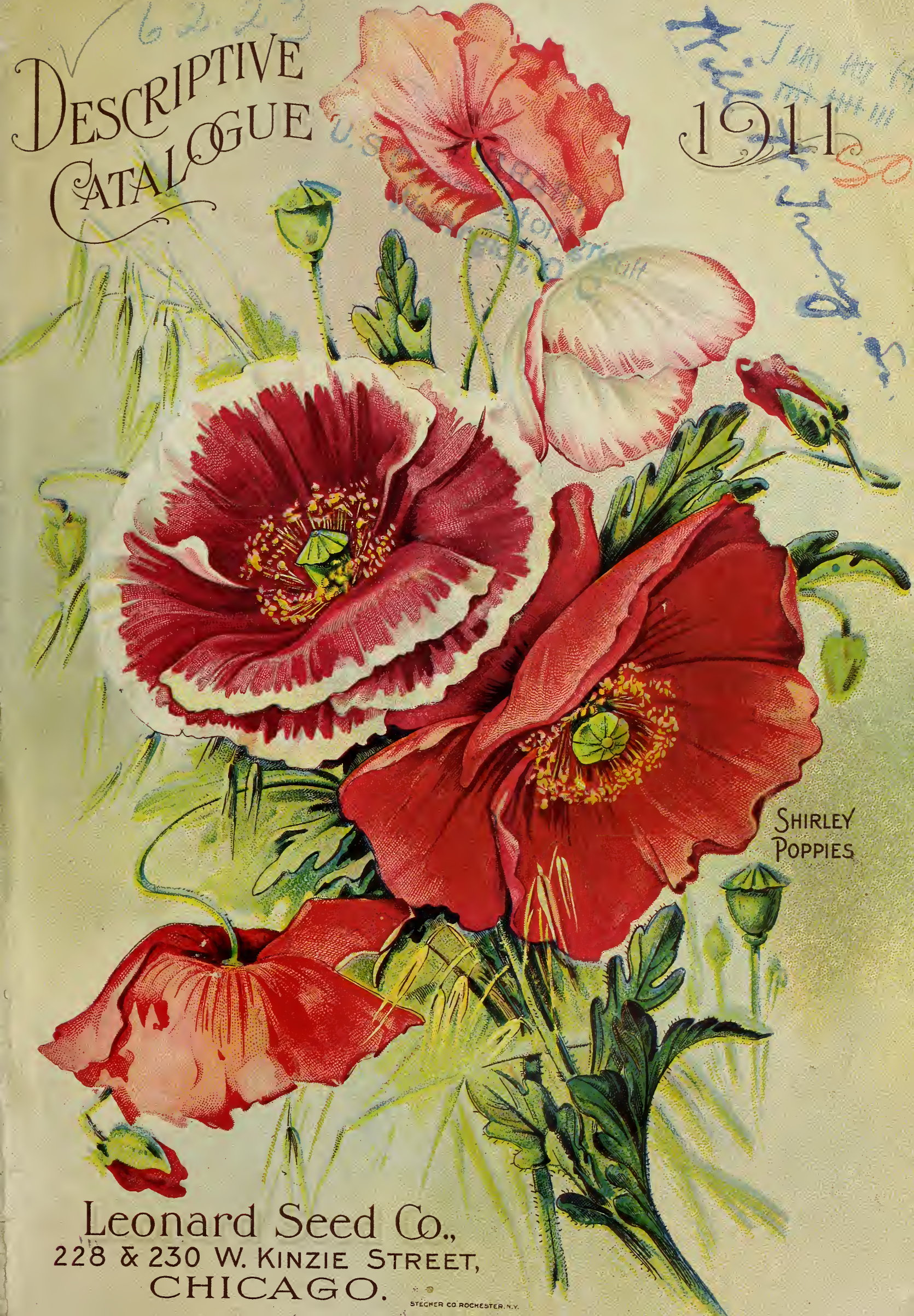




\section{A NEW LEADER}

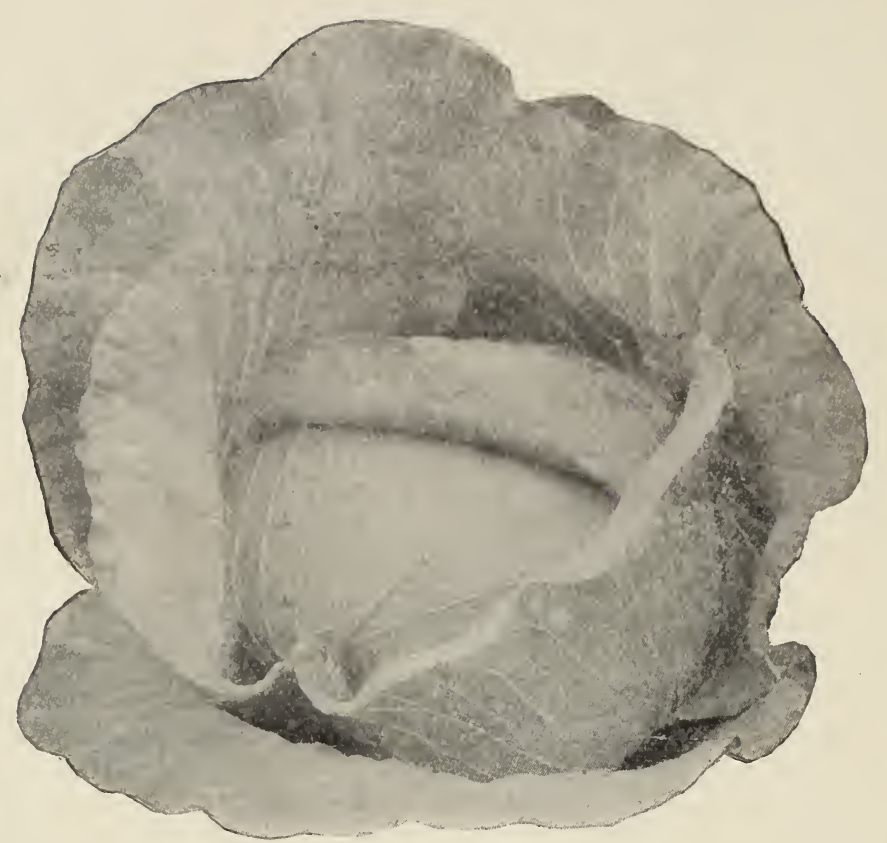

LEONARD'S WINTER CABBAGE

\section{LEONARD'S WI N T E R CABBAGE}

This new cabbage originated in that part of the Niles Center trucking region known as the East Prairie, which is one of the best cabbage growing sections of Chicago.

It is a direct cross of the Leonard Luxem = berg and the Leonard Strair of Holland and combines the good points of both. It has the shorter stem and more lasting color of the Luxemberg with the rounder head of the Holland. 'The combination gives a cabbage that is superior to either. Three years ago we obtained from one of our best growers enough selected heads to give us stock seed and from this stock we raised, during the past year, a good crop of seed.

Leonard's Luxemberg Cabbage was introduced by us about twenty-four years ago and Leonard's Strain of Holland Cabbage some ten years later. These two have been the leading winter cabbages up to the present. We now introduce this New Cabbage which originates from the two and can fully recommend it to all cabbage growers as a stock that will be even more satisfactory than either of its famous parents. There has been a great demand for seed of this variety during the past few years, but until this season we have been unable to raise more than just sufficient stock seed to keep the variety from being lost. Our supply this year will not be sufficient for the full demand, but it will go partly around.

Packet 10c.; Ounce, 40c.; One=fourth Pound, $\$ 1.25$; Pound, $\$ 5.00$.

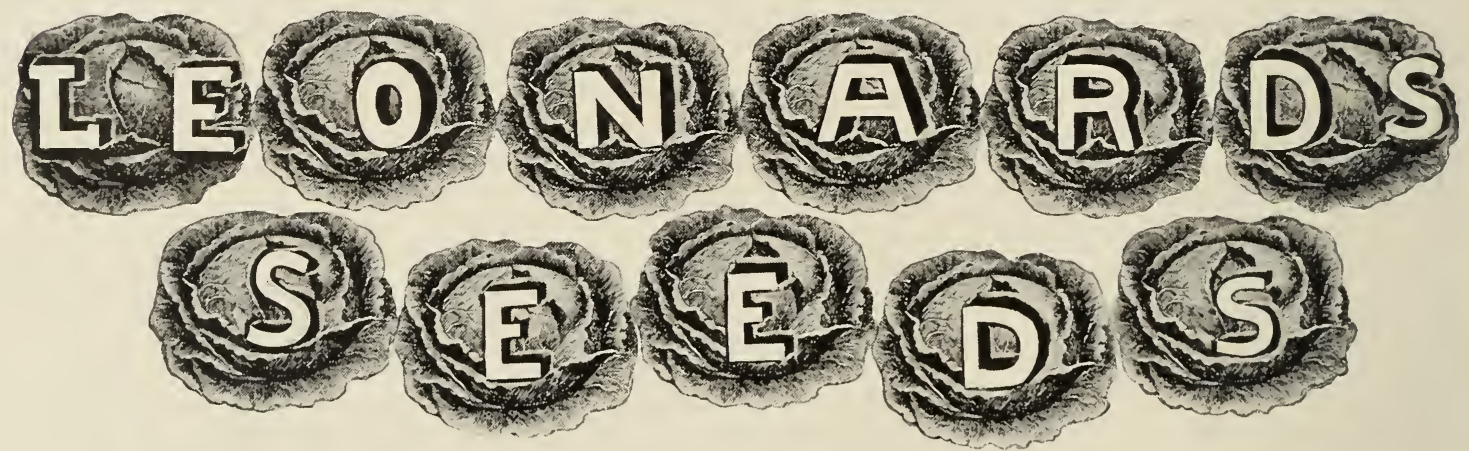

\section{THOUSAND HEADED KALE}

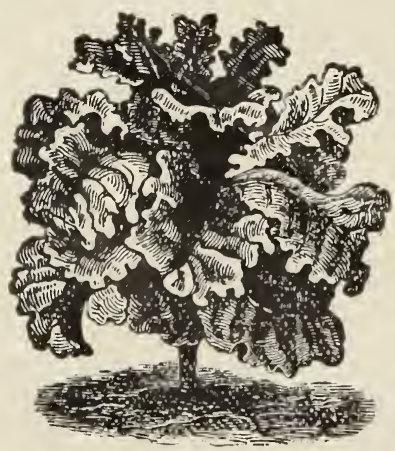

This is a variety of non-heading Cabbage that is highly esteemed as a vegetable as well as for stock feeding purposes. It is very productive and is quite hardy. For cattle and sheep feeding it is superior to the Essex Rape, being more tender and nutritious. In the South it has been found to be of great value as a winter vegetable and in all sections it has proved to be the most economical forage plant for sheep and cattle feeding.

One=fourth pound 15c. Pound 40c. Postpaid;

by Express at Expense of Purchaser 10 pounds $\$ 2.50$. 


\section{In Presenting

to our customers we do so with no small degree of pride, as illustrating a growth attained through untiring effort and care in the interests of our customers, many of whom have been with us since the small beginning in 1884, a period of more

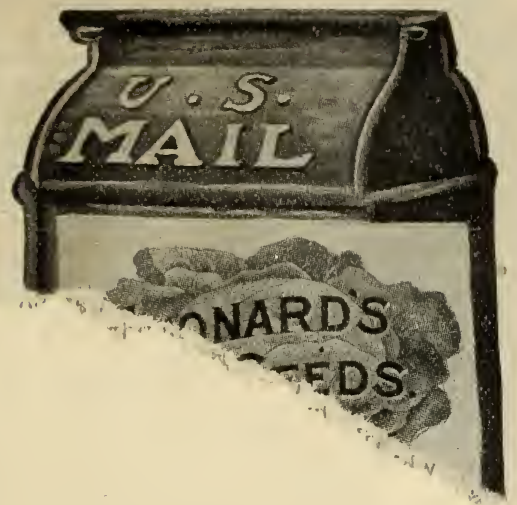

than 26 years. Seeds are bought on confidence and Leonard Seed Company's aim is to have the confidence of the Seed buying public as the most Reliable Seed House.

\section{TERMS OF SALE}

WE GIVE NO WARRANTY express or implied as to purity, description, quality, productiveness or any other matter of any Seeds, Bulbs, or Plants we send out, and we will not be in any way responsible for the crop. If the purchaser does accept the goods on these terms they are at once to be returned, and any money that has been paid for same will be refunded.

SEND CASH WITH THE ORDER. This can be done either in the form of a Money Order, Bank Draft, Express Order, Registered Letter, or cash may be sent by express. Remittances sent in any other way are entirely at the sender's risk. Small amounts may be sent in postage stamps.

-IGN YOUR NAME. Name and address should be written inly as possible and care exercised to have Postoffice, 'd State in full. If your express office or freight different name from your postoffice, give that also. portant, as we cannot send goods if we do not in them.

" LY THE PRICES. Be sure to know s o pay the freight or express, and bear * 1 y the express or freight charges on

$\mathrm{v}$ tools or plants, nor on potatoes,

'izers, except where we so state $\%$ priced.

S. It sometimes happens $r$ the goods in going to ter ${ }^{3}$ from

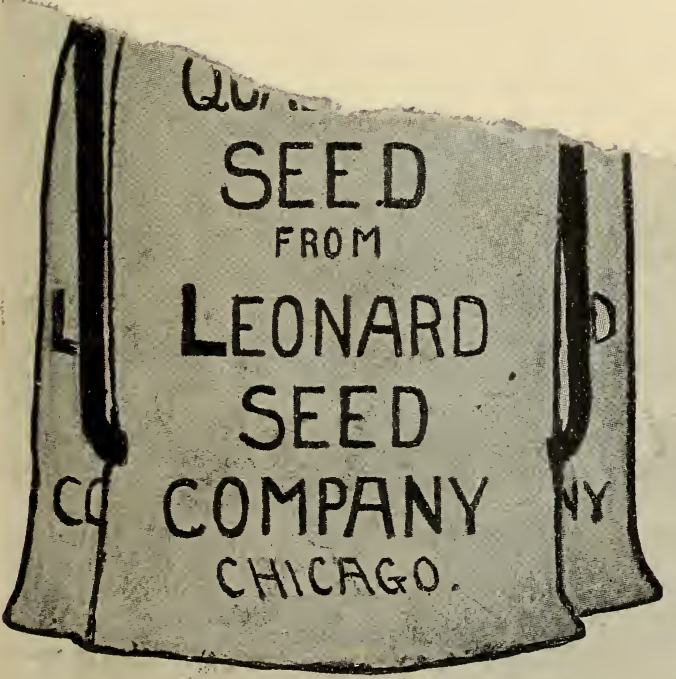

we

make yuus

ordered, and ais

catalogued, beginu:

you additional order

ORDER EARLY. We

soon as this catalogue reach'-

You will aid us and get quicker s

WE PAY POSTAGE OR EXPRESSAGE Gi.

by the packet, ounce, quarter pound and pounc and quarts of Peas, Beans and Sweet Corn, and o. bulbs except where noted otherwise, and upon quoted in our catalogue where it says: Prepaid b. Express.

WE AIM TO GIVE SATISFACTIION. We make our cata as plain as possible, both as to descriptions and illustratio.

THE PRICES WE QUOTE on vegetable and flower seedi will hold good as long as stocks last. The prices on grass seed, grains and all farm seeds are those ruling January 1st, 1911, and are subject to change. As far as pos sible we will fill in full all orders for seeds that are quoted subject to variation in price, but if market values will not permit this, we will send all that money remitted will pay for. 


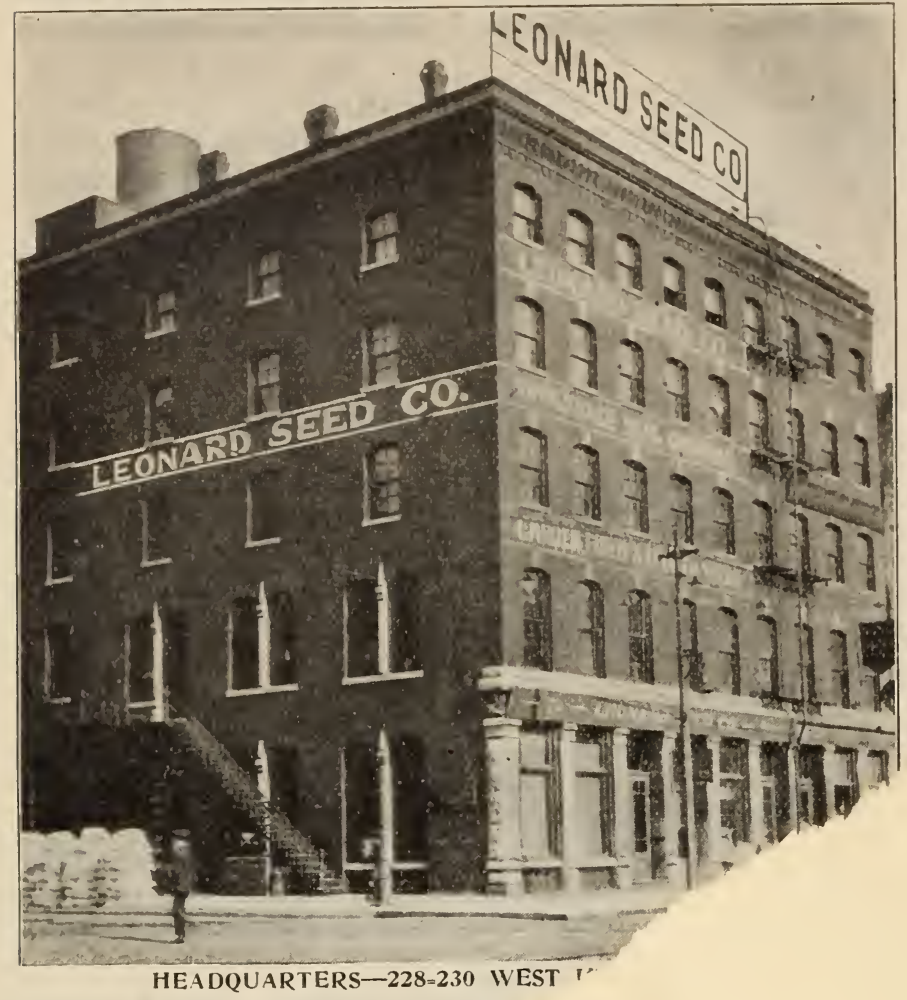

\section{OUR PRINCIPAL WAREHOUSE}

Our principal warehouse and general office is situated at ('hicago, numbers 226-228-230 IVest Kinzie street, at the Northeast corner of Franklin. All of our business is transacted from this office and all of the General Wholesale Seed Orders are filled from stocks carried at this house on account of the exceptional freight and express service we are able to obtain.

In addition to the large storage capacity of our out of town Pea and Bean warehouses. we have at our headquarters we hn storage capacity of one $1 \cdots \cdots+$ bushels for Peas and $F$.

able increase in $t^{1}$ : ments of our $r$.

trade, as w"

views $v-1$

this

\section{MAIN RETAILSTr}

At Halsted and Randolph stre our largest Retail and $\mathrm{Ma}^{\text {r }}$ Store. This is in the cer

Vegetable Market, know

Square Store this?

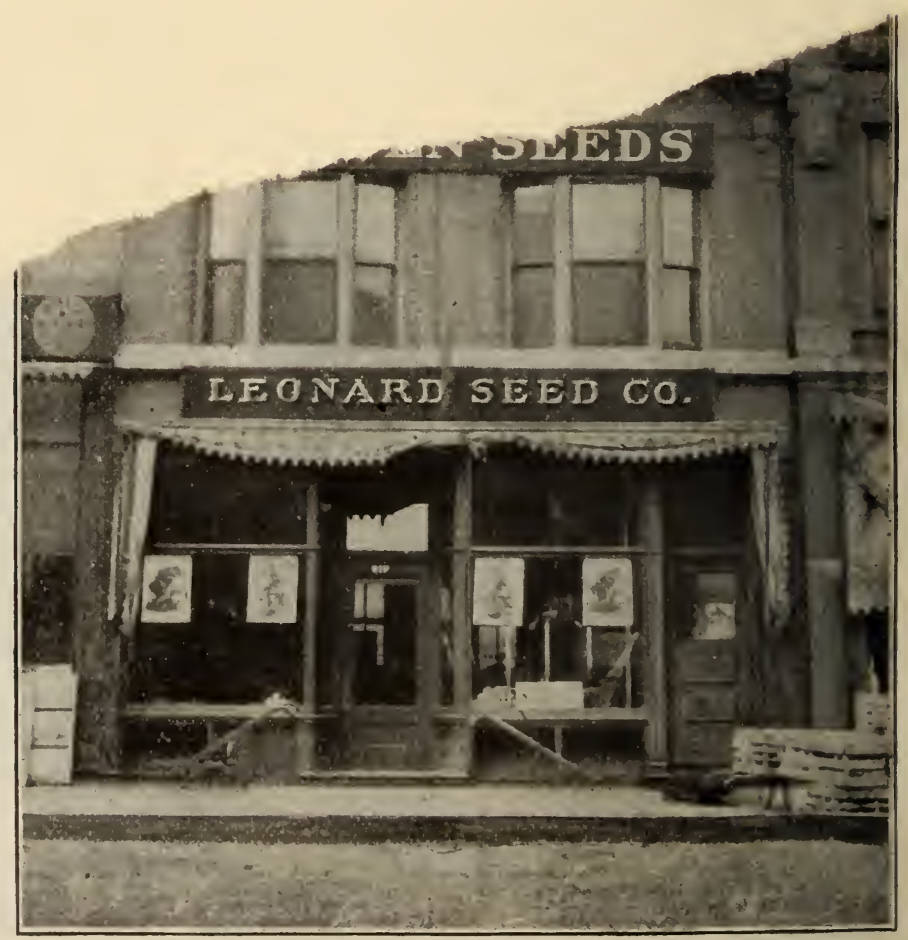

uers desire this w nel gardeners' seedse to give it. This knowlve acquired from books, aliy able market gardeners have oks that help greatly. It can be from experience only, and it relong continued experience at that. inanaging heads of each department of ur business are practical workers in the rield as well as in the warehouse, and our regular empluyces work on our farms during the summer and in our stores and warehuuses in the winter. It is this combination of theory and practice that rounds out a seedsman and puts him in a class considerably in advance of they who ordinarily pass as being qualified. If we shall fail here to make.it plain that Leonard Seed Company qualifies as market gardeners' seedsmen, we shall at any rate feel sure that no others have got past us in the path that leads thereto. 


\section{Our Branch Stores}

Three years ago we found it necessary on account of increased retail business as well as from the fact that the gardening sections were being pushed out farther from the heart of the city to open up Branch Retail Stores. Our first branch store was opened at 4317 Milwaukee Avenue in Jefferson Park, Chicago. This past season we have removed our Jefferson Park branch into larger quarters at 4845 Milwaukee Ave. This store is situated North West of the city and is inside of the city limits. The customers we have in this section constitutes Market Gardeners who plant diversified crops, and that section includes a very large territory, as the city has grown and the gardening sections of it have been pushed out to some twenty or thirty miles from the heart of the city. The location of this store being ten miles from the heart of the city, makes it about half way between the town, and the gardening section which is very convenient.

It is quite generally known that we have a very large trade with Market Gardeners, probably the largest of any seed house. This branch of the trade has been made a specialty of by us during the twenty-six years that we have been in business.

We do a good deal of farming ourselves adjoining the fields of the market gardeners who patronize our Jefferson Store and this makes them feel that we are workers the same as they are. This is of great advantage to us, and our customers think it is of considerable value to them. Besides this we have them grow onion sets for us and it quite frequently happens that we buy as much from these gardeners as they do from us. This reciprocity is a good thing all around.
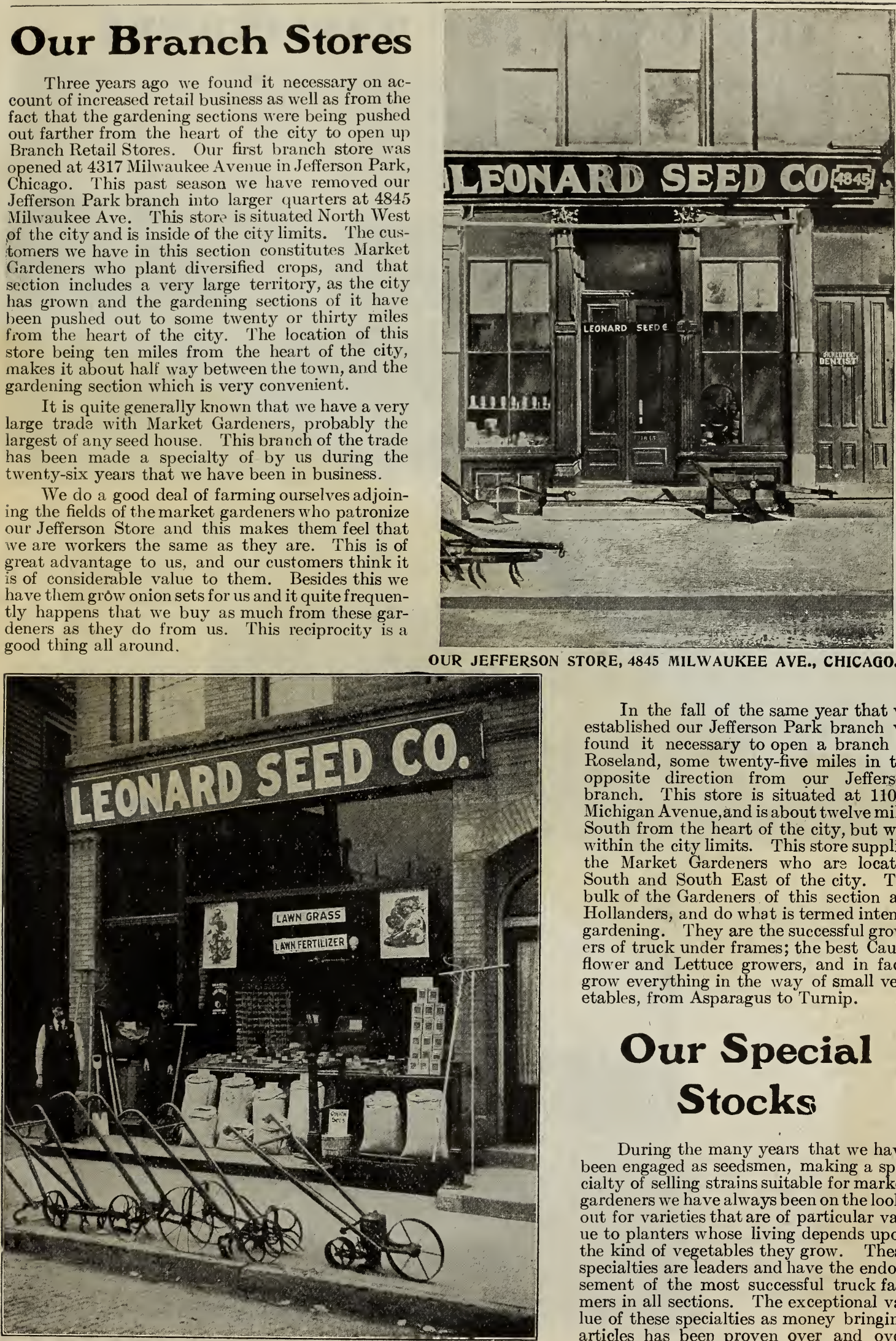

In the fall of the same year that we established our Jefferson Park branch we found it necessary to open a branch at Roseland, some twenty-five miles in the opposite direction from our Jefferson branch. This store is situated at 11033 Michigan Avenue, and is about twelve miles South from the heart of the city, but well within the city limits. This store supplies the Market Gardeners who are located South and South East of the city. The bulk of the Gardeners of this section are Hollanders, and do what is termed intense gardening. They are the successful growers of truck under frames; the best Cauliflower and Lettuce growers, and in fact, grow everything in the way of small vegetables, from Asparagus to Turnip.

\section{Our Special Stocks}

During the many years that we have been engaged as seedsmen, making a specialty of selling strains suitable for market gardeners we have always been on the lookout for varieties that are of particular value to planters whose living depends upon the kind of vegetables they grow. These specialties are leaders and have the endorsement of the most successful truck farmers in all sections. The exceptional value of these specialties as money bringing articles has been proven over and over again by those who plant our seed. 


\section{OUR ONION SET WAREHOUSES}

We are the largest handlers of Onion Sets, and our storage warehouses for this article are most up-to-date and perfect. Warehouses $\mathrm{A}$ and $\mathrm{B}$ have a storage capacity of sixty thousand bushels. IVe stack our filled crates in the warehouses in rows to the height of forty to fifty, leaving air spaces between the piles and between every two rows and aisle wide enough to run platform trucks between. Warehouse A is 85 feet wide by : 165 fcet long. Warehouse B is 72 feet wide by 108 feet long. The splendid track facilities of warehouses $A$ and $B$ will be noticed in the picture.

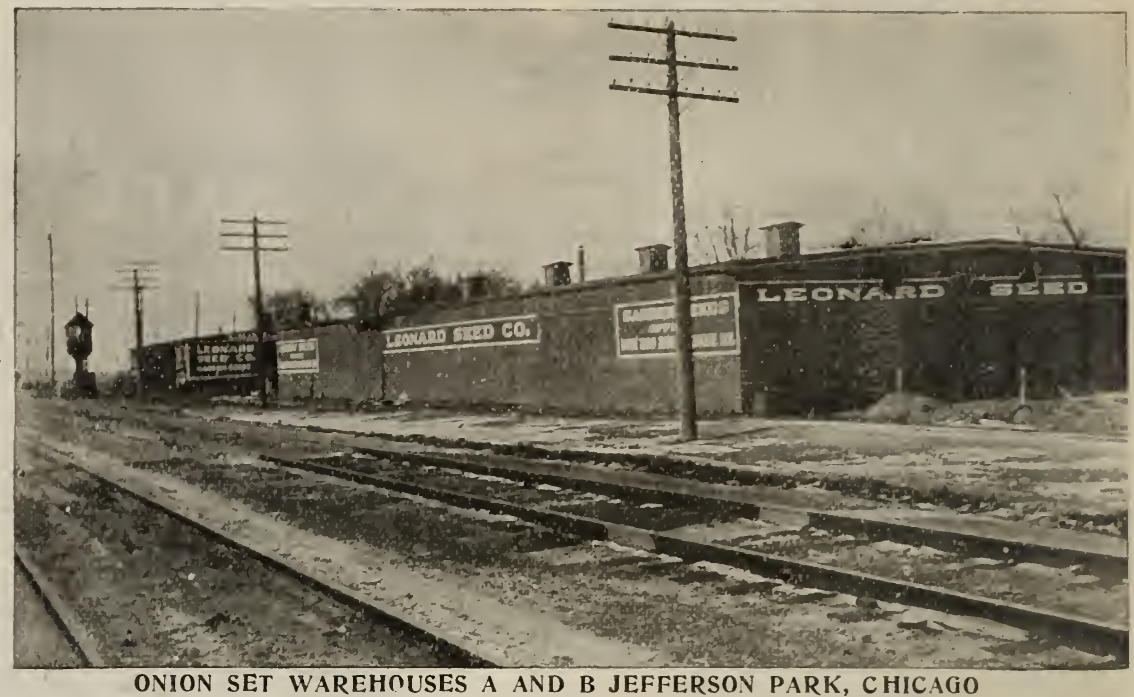

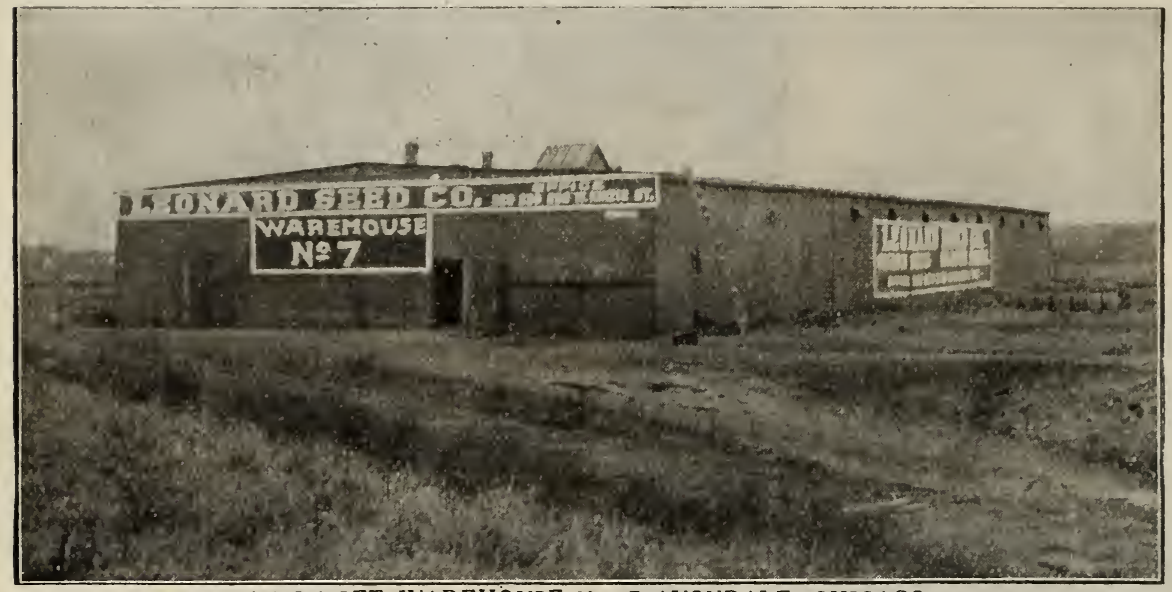

ONION SET WAREHOUSE NO. 7 AVONDALE, CHICAGO
Onion Set Warehouse No. 7 has a capacity of thirty thousand bushels. It is 65 feet wide by 176 feet long. Warehouse No. 8 is our best and largest onion warehouse: it has a capacity of forty thousand bushels and its milling and shipping facilities leave nothing to be desired.

This style of onion set warehouses which originated with us has been copied generally by other growers. All think it is the best type of onion house.

These warehouses are made frost proof and each is equipped with a hot water plant by which heat may be turned on when necessary. Each of our onion set warehouses has its milling equipment and each is located on a railroad with track shipment f a c ilities. The storage capacity of these onion set warehouses gives us room to store our onion set properly and being built on scientific principles, the sets in them usually carry safely until time of shipment in t':e spring. Chicago is now the largest onion set growing center and the Leonard onion set in the Chicago Standard.

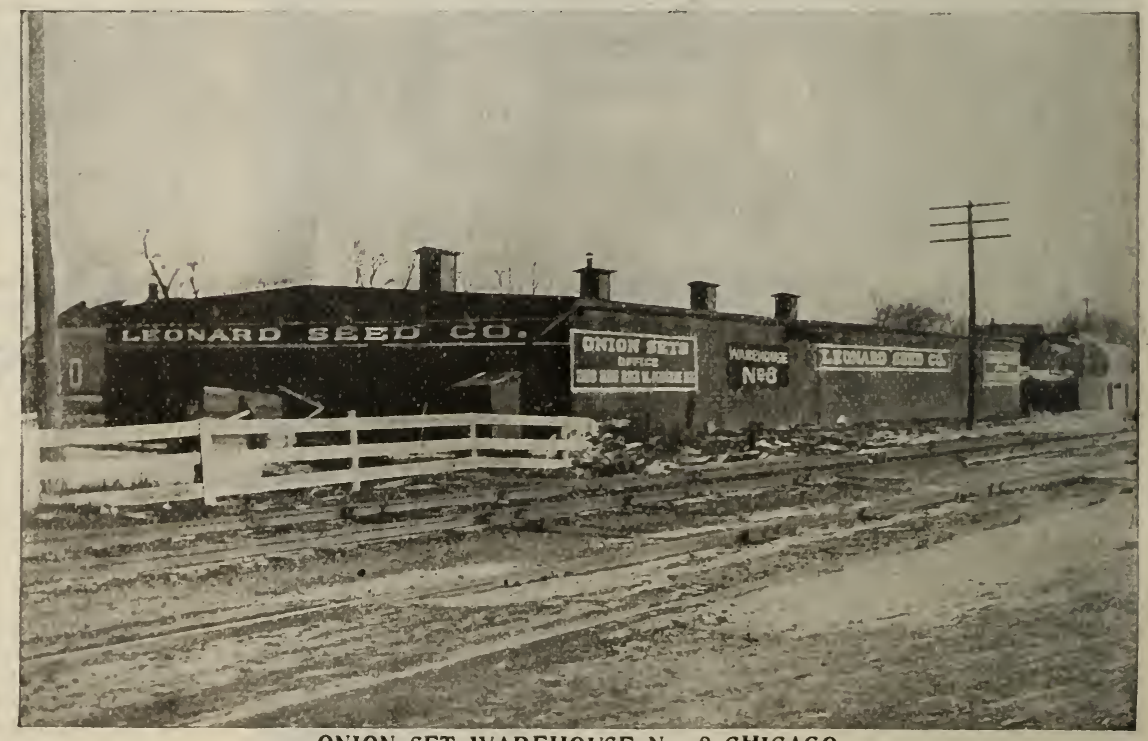




\section{OUR PEA AND BEAN WAREHOUSES}

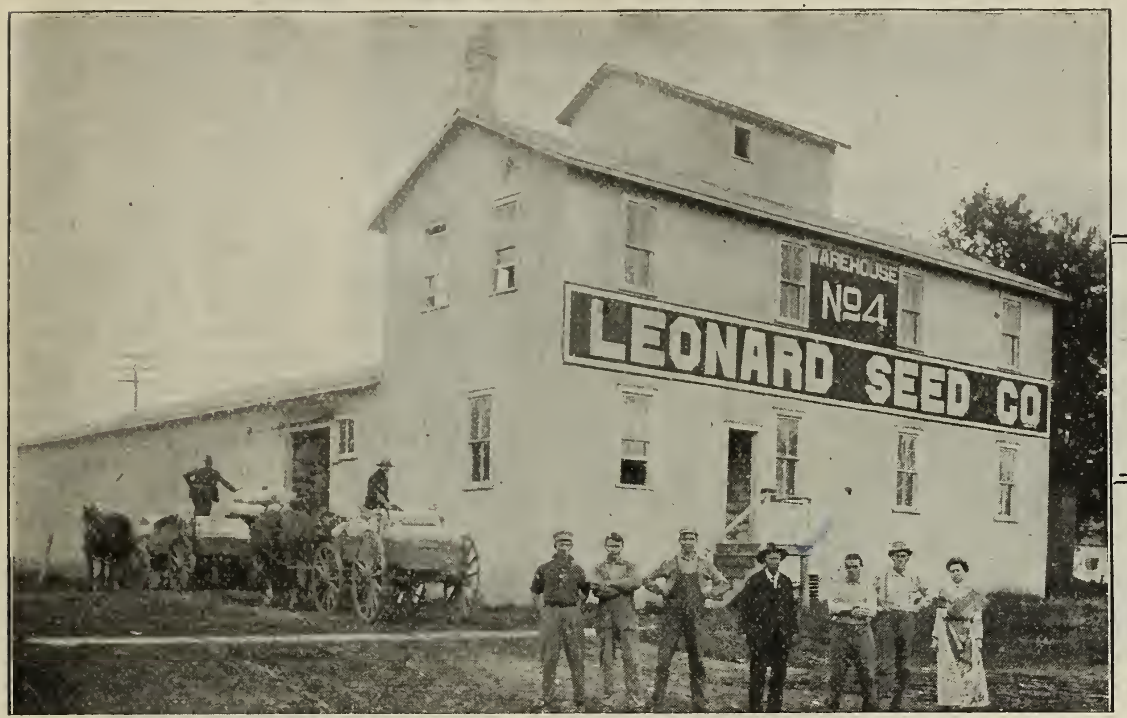

Our Warehouses at our different growing stations are fully equipped with milling and picking machinery. Direct shipments of carload lots are made from these warehouses whenever it is practicable.

Pea Warehouse No. "4," located at Columbus, Wis., which has a storage, milling and pickling capacity of $20,000 \mathrm{bu}$. Peas.

Most of the seed handled at this house is grown for canner and packer.

The employees at these warehouses when not occupied in receiving, milling and shipping are out arranging for the coming year's crop, which in turn is followed by inspecting, rougeing and harvesting.

With the addition of these branch warehouses the congestion that our constantly increasing business occassioned at our headquarters warehouses in Chicago has been very materially lessened.

Pea Warehouse No. " 5 ," at Antigo, Wis., where some of our very choicest stock of garden varieties of Pea seed comes from. This warehouse has a storage capacity of 15,000 bushels.

We now have better opportunity at headquarters to handle the increasing quantities of Garden Seeds, such as Beet, Carrot, Cabbage, Lettuce, Onion, Radish, etc., that are required by our trade.
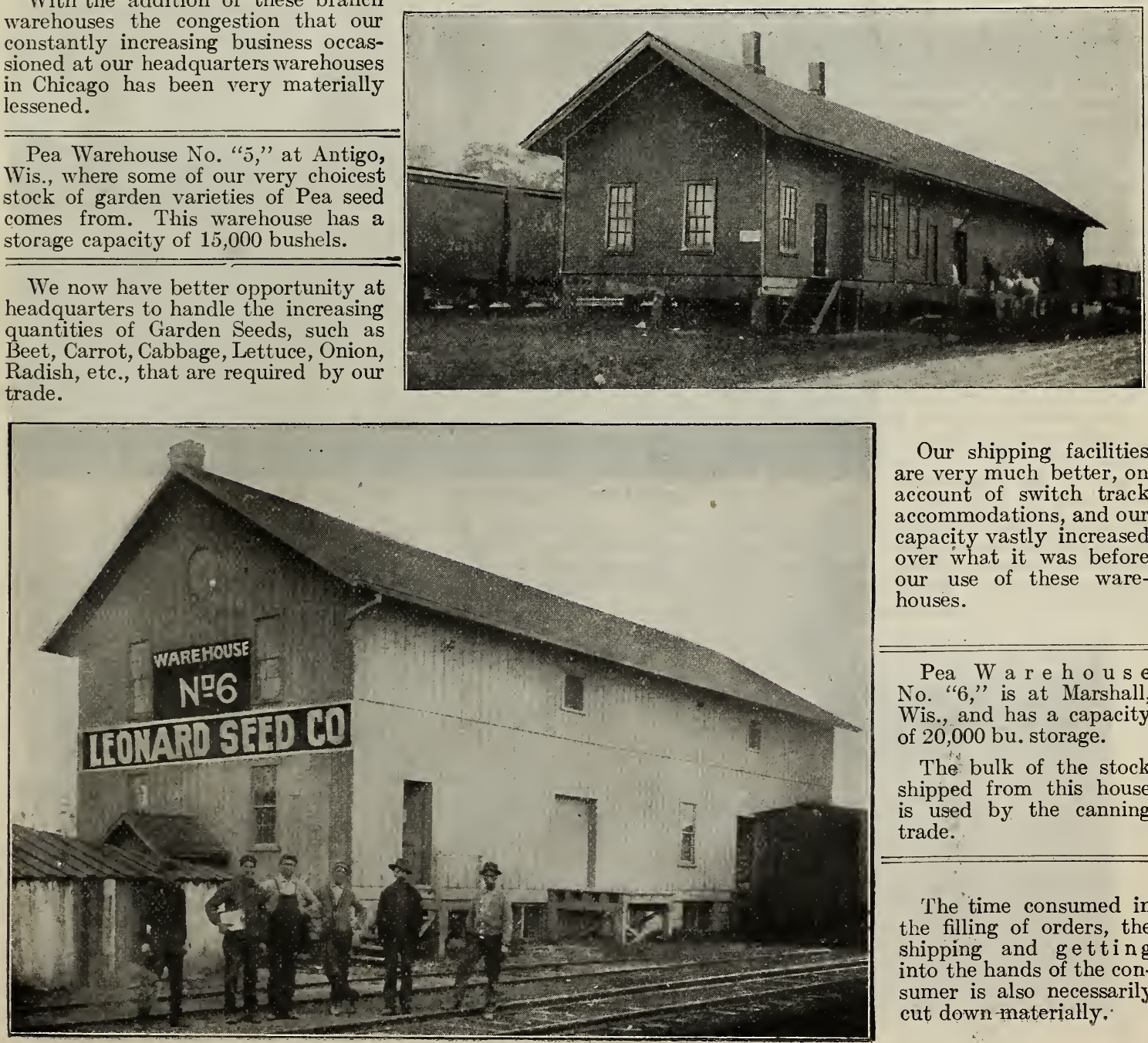

Our shipping facilities are very much better, on account of switch track accommodations, and our capacity vastly increased over what it was before our use of these warehouses.

Pea W a r e h o s e No. "6," is at Marshall, Wis., and has a capacity of $20,000 \mathrm{bu}$. storage.

The bulk of the stock shipped from this house is used by the canning trade.

The time consumed in the filling of orders, the shipping and getting into the hands of the consumer is also necessarily cut down-materially. 


\section{OUR ONION SET FARMS}

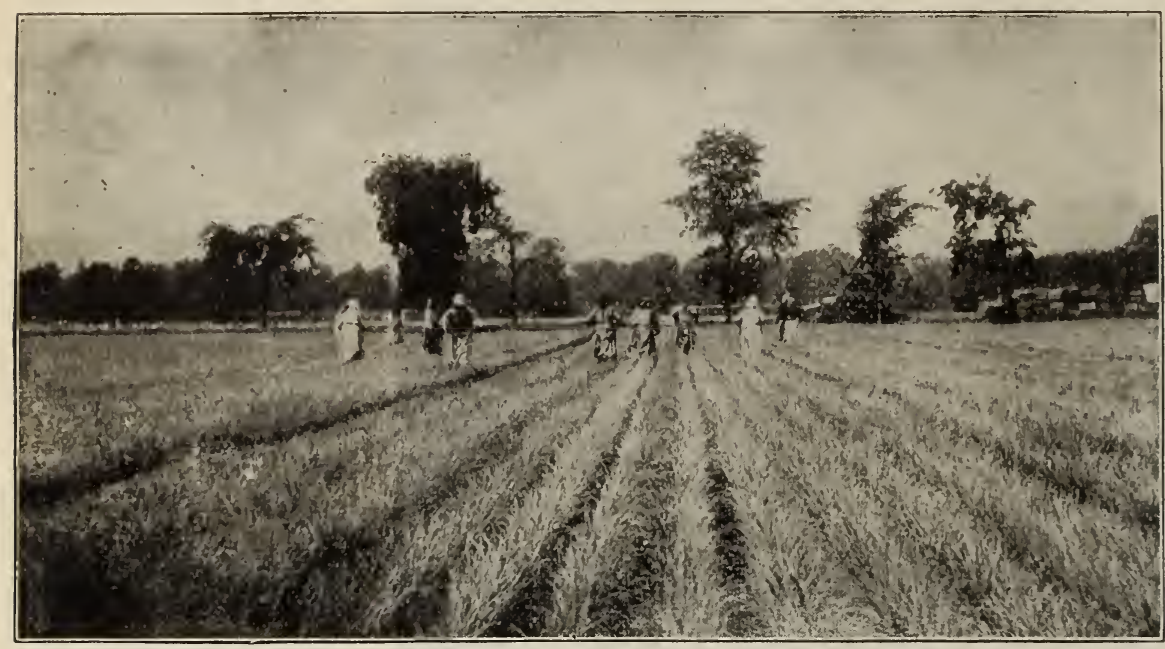

WORKING CULTIVATORS IN ONION SETS AT JEFFERSON PARK FARM
Our Farms where the Onion Sets are grown are located in the Jefferson Park vicinity and at Avondale. We are the Pioneer Onion set growers of Chicago, We began on a small scale the second season after be inning business, or in other words in 1886, and from that time on we have continued to increase our output of this crop until at the present time, the quantity, that we handle is exceedingly large. The land that we work is particularly adapted to the growing of Onion sets, and the nearness to the city makes it easy for us to get what help is needed to weed, cultivate, and harvest the crop.

When weeding the Sets in June we use as many as 300 wómen a day. The top view shows the cultivators working in between the rows. This cultivating is kept up every day during the growing season. The middle view shows the hand weeding. During Harvest we use more people than at any other time, having as many as 500 in the fields when the crop is harvested.

The manner in which the Onion Sets are harvested - The bottomView on this page shows how we harvest onion sets. The crates lying on the ground are $4 \mathrm{ft}$. long by $3 \mathrm{ft}$. wide,

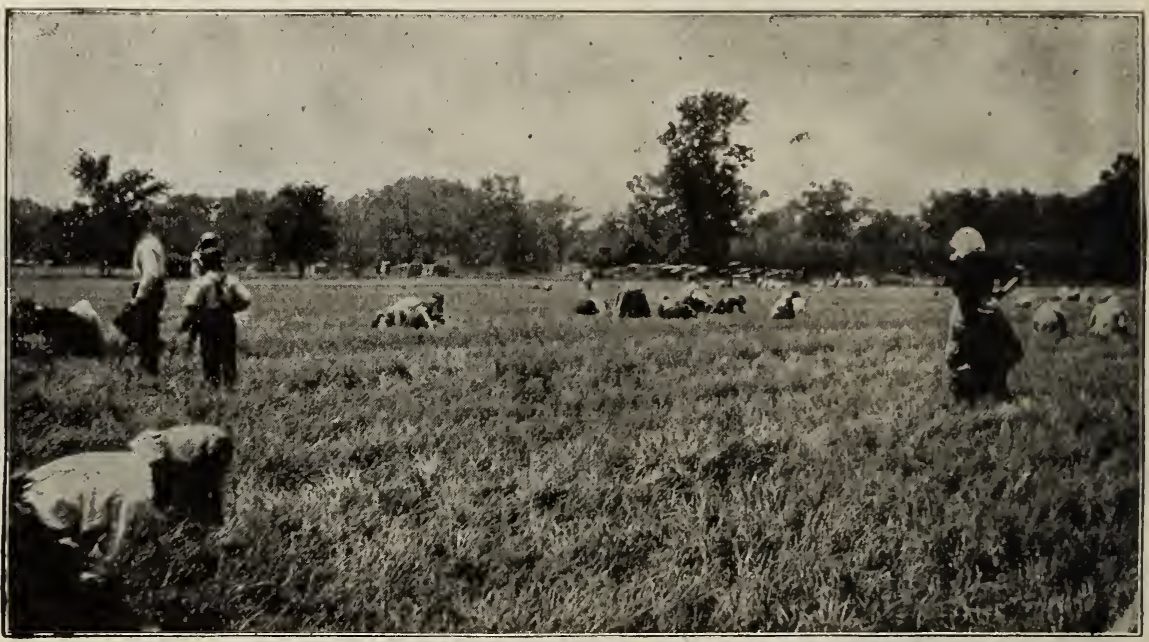

WEEDING ONION SETS AT AVONDALE FARM

the end pieces are 4 inches high and the side pieces 3 inches high which give ventilation spaces of one inch between each when piled up. The bottoms of these crates are made of lath, nailed not too closely together, which gives bottom air spaces. These crates can be piled 40 high when necessary. The onion sets are pulled by hand, the tops wrung off and then placed in the crates drying off during the day on the ground and piled up at night. They are allowed to remain in the piles on the field until well cured and then taken into the warehouses.

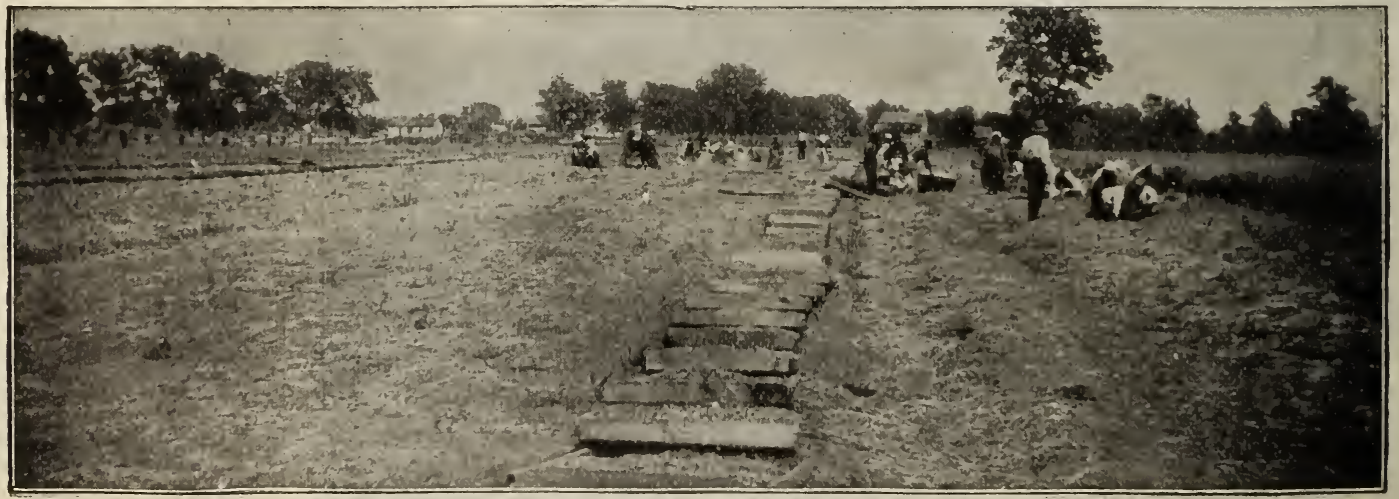

HARVESTING ONION SETS JEFFERSON PARK FARM 


\section{OUR CHICAGO TRIAL GROUNDS AND FARMS}

Our Trial Ground work is most complete and upto-date. We maintain three large trial and testing grounds. One in Chicago at Avondale station, one at Columbus, Wis. and one at Antigo.

At Avondale this vear, we tested from 1400 to 1600 different lots of seed. This work is under the careful supervision of experts, who do nothing else other than watch the growth from day to day, and who make careful and extensive records of conditions prevailing at different stages of growth. At our Avondale Farm our employees are given every opportunity of seeing what good seeds can produce and the methods by which the best results

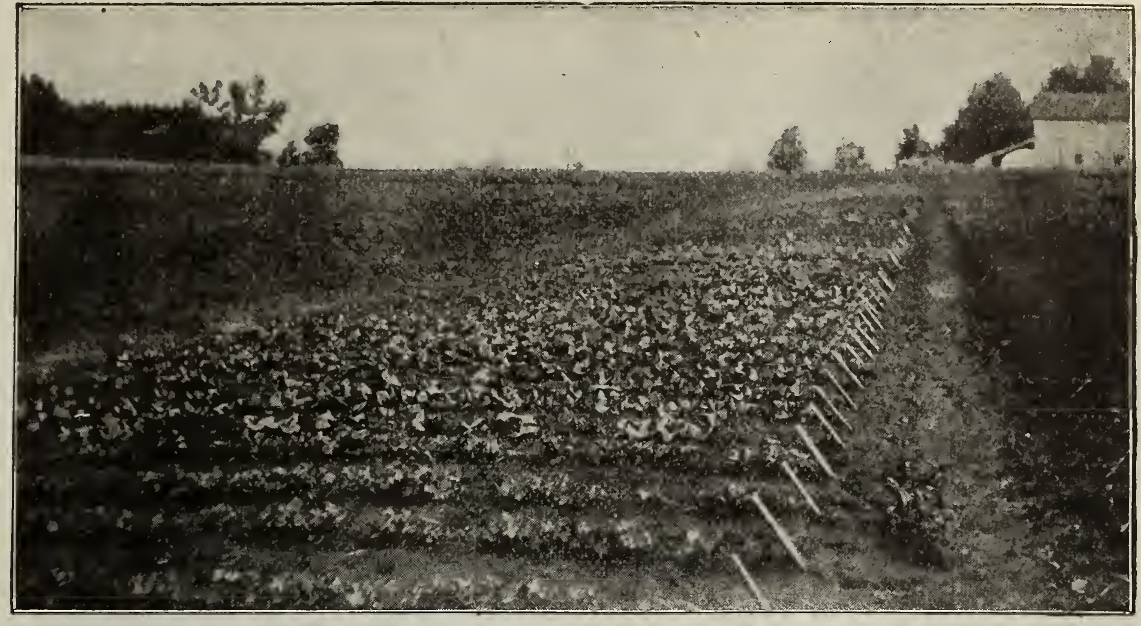

TRIAL GROUNDS AT AVONDALE FARM-CHICAGO may be obtained in cultivating them. We use a considerable part of this farm for onion set growing.

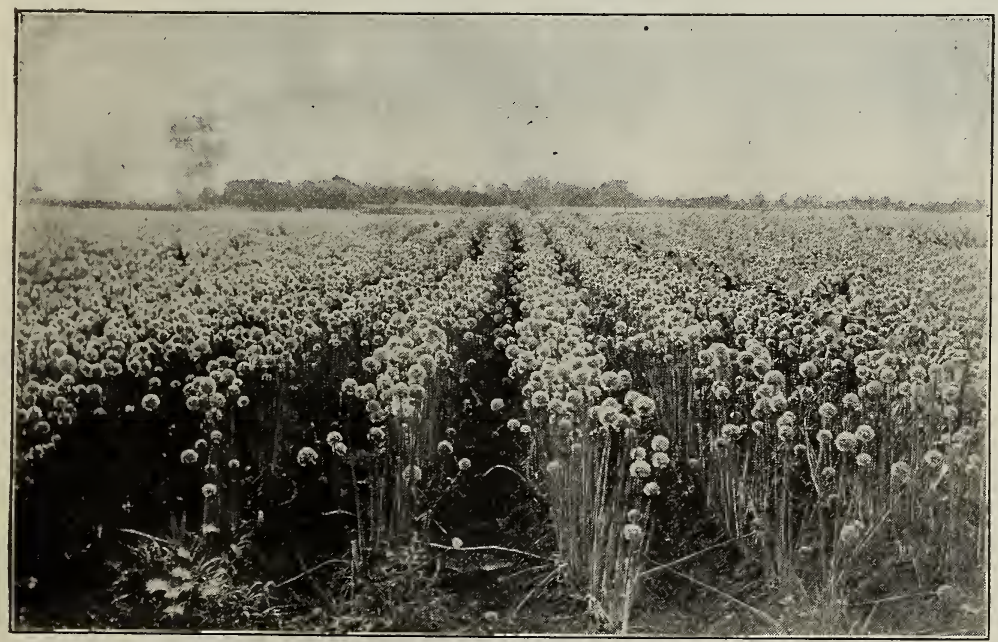

The Trial Grounds at Avondale are given over for the most part to testing small seeds such as, onion, lettuce, radish, carrot, beet, etc. It is here that we test each lot of seed sold by us both for germination and purity. These facts in connection with the elaborate stock record system and records of shipments made to customers, keep us in direct touch with the crop as well as of each lot of seed shipped to any one of our customers.

Our Jefferson Farm is located inside the limits of Chicago. The important thing about this farm is its location. Some of the best market gardeners of Chicago have their land adjoining it on every side. There is hardly a vegetable known to the seed trade but what can be seen growing in the vicinity of it.

FIELD OF LEONARD'S YELLOW GLOBE ONIONS, JEFFERSON FARM

The knowledge to be gained by noticing what is being done by these gardener's and the progress of different crops

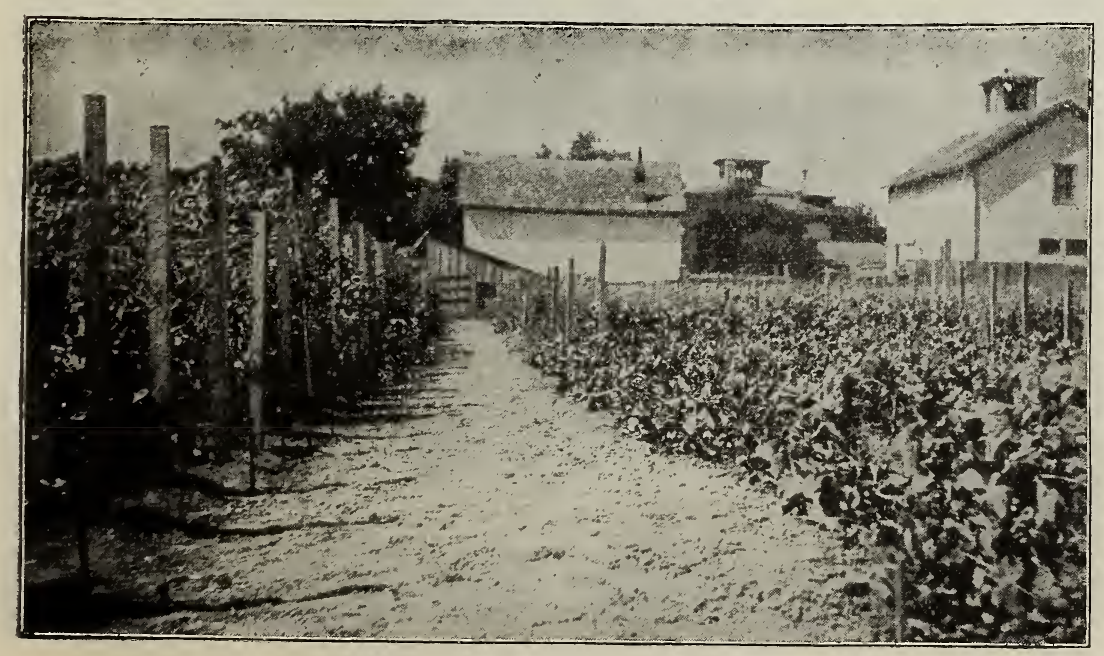

ADDITIONAL TESTING OF VARIETIES under ordinary every day conditions and methods of culture are most valuable to a seedsman. In the center of the page is a view of a field of Leonard's Yellow Globe Onion making seed at our Jefferson farm. To get the proper kind of onion seed it is necessary to select bulbs of the type that is required. We have been growing onion seed, and selecting bulbs each year during the whole time that we have been in business with the result that our types are as near to standard as it is possible to have them. The quantity of onion seed that we need for our own planting in addition to that which we sell to our customers is very large, and the onion seed product of our farms is a very important item. 


\section{Our Stock Improvement Methods}

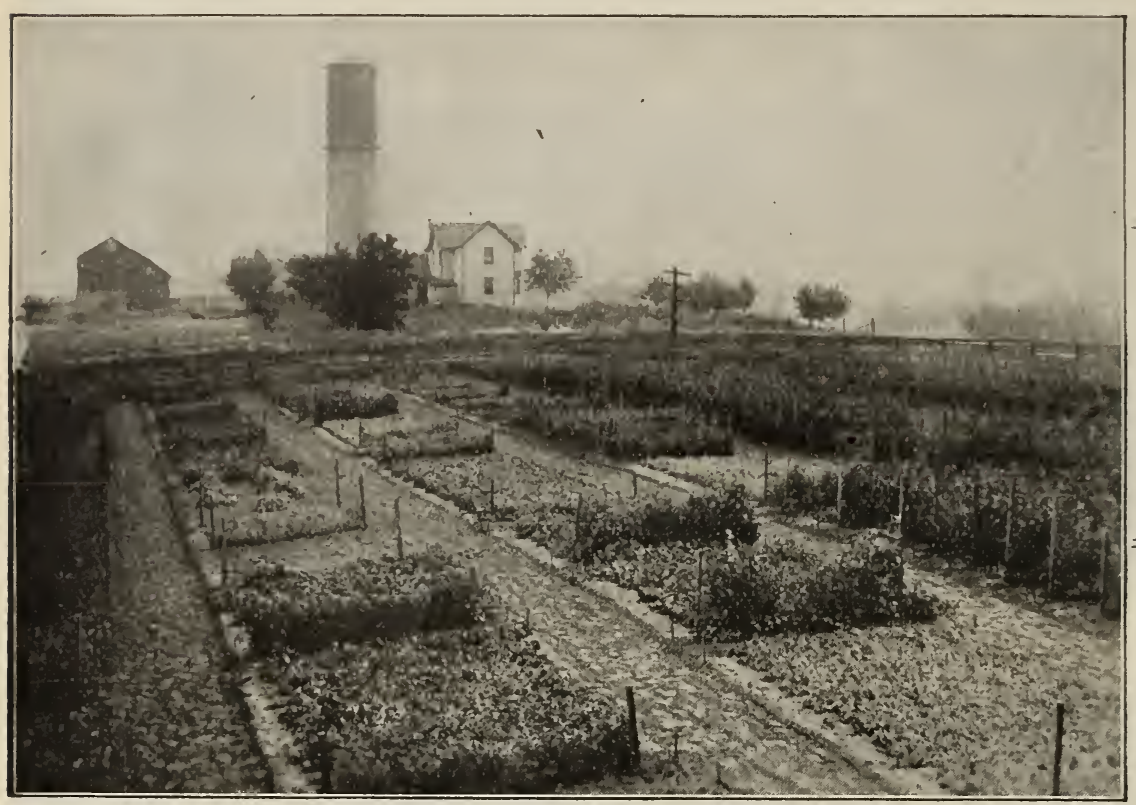

At Columbus we do more testing of Peas than anything else and also dc all of our stock improvement work as well as experimental work on producing new varieties.

A bird's-eye view of a section of peas at Columbus, showing the trials growing in wire and in the left foreground manysmall blocks of peas which are being bred up and improved. We have thirty acres given over to this sort of work.

We appreciate more and more the importance of having our Pea stocks true to type and know how easily the varieties revertback to the wild state, for these reasons we continue our work of stockimprovement which we began years ago and on this and the following page may be seen views of how this work is done by us. The bird's-eye view of a section of our Columbus stock improvement garden shows in part the many small blocks of Peas that are being bred up and improved. IVe have thirty acres given over to this work. In the front of catalogue, tipped in is a panel view which, to some extent will give an idea of the scale upon which we are working to maintain the purity of our stocks. We eliminate anything that has a tendency to sport in our stock of Peas. The se 2 d that is grown and improved in this way is used to prodice stock seed for the coming year. By stock seed we mean seed that we plant ourselves to produce the stock that we give to the farmers who grow quantities for us. It is well known that it is impossible to take a large crop and rogue it well enough to eliminate everything that might be wrong in it, but by eliminating from the stock seed all the spurious plants, we get a stock that will produce a crop that will be as near as possible free from sports. We have spent a great deal of time in the last few years on the Alaska Pea, as we had found it to be deteriorating very rapidly, and the orizinal type being almost lost. We believe that now we have the very best type of Alaska Peas that can be found anywhere.

In addition to the Alaska Pea we now have succeeded in breeding up splendid stocks of Horsford's Market Garden, Advancer, and Abundance Peas, as well as other stocks of the standard varieties.

A peep down one of the paths between two rows of trials-each stake represents a different lot of peas. These are all on wire of which we use more than five miles, in order that an inspection may be made of the row from top to bottom.

We invite attention to the view at the bottom of page 9 . It shows clearly the careful manner in which the stockimproving is done.

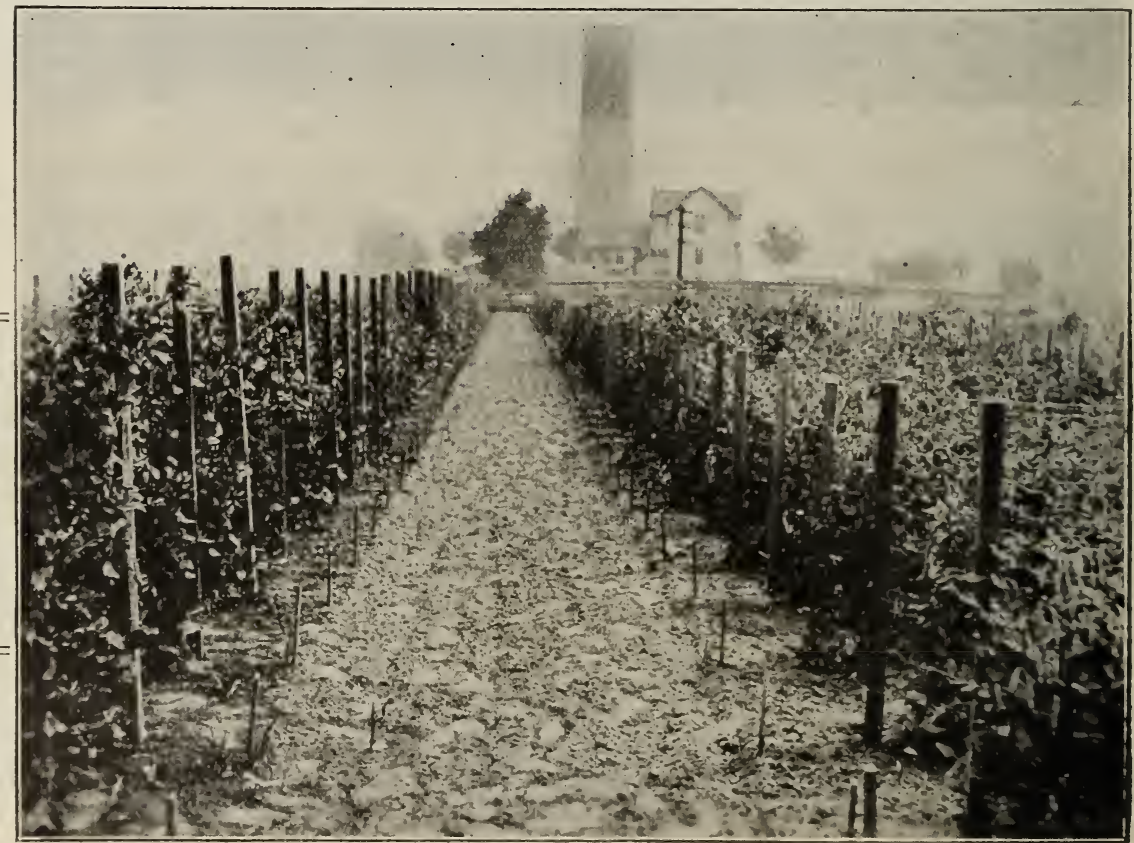




\section{Our Stock Improvement Methods}

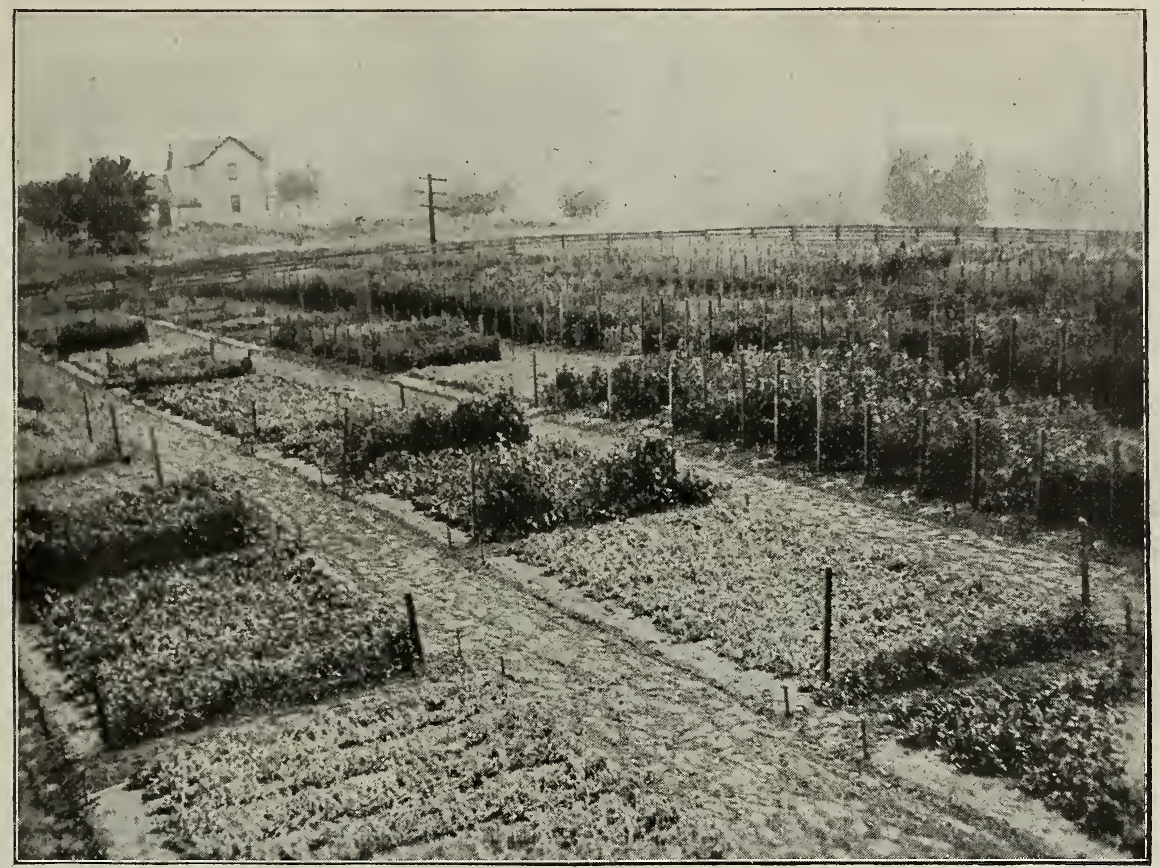

PEA TRIALS AT OUR COLUMBUS, WIS., PLANT

Attention is called to the two Views on this page. Each view represents a purpose and the purpose is to establish as nearly as possible a stock of seed peas that will be true to type when planted for a crop. This is not easy of attainment; care is required and judgment must be exercised; the results may not be all that is desired, but it is an advance. Our efforts along the line of improving stocks is more than repaid by the appreciation of our customers and the increased volume of the business that we are receiving. It is not alone in peas that we are working but in beans, radish, cucumber and all other stocks of Garden Seeds. We feel confident that in our operations in the line of seed growing and stock improvement we are well up toward the front.

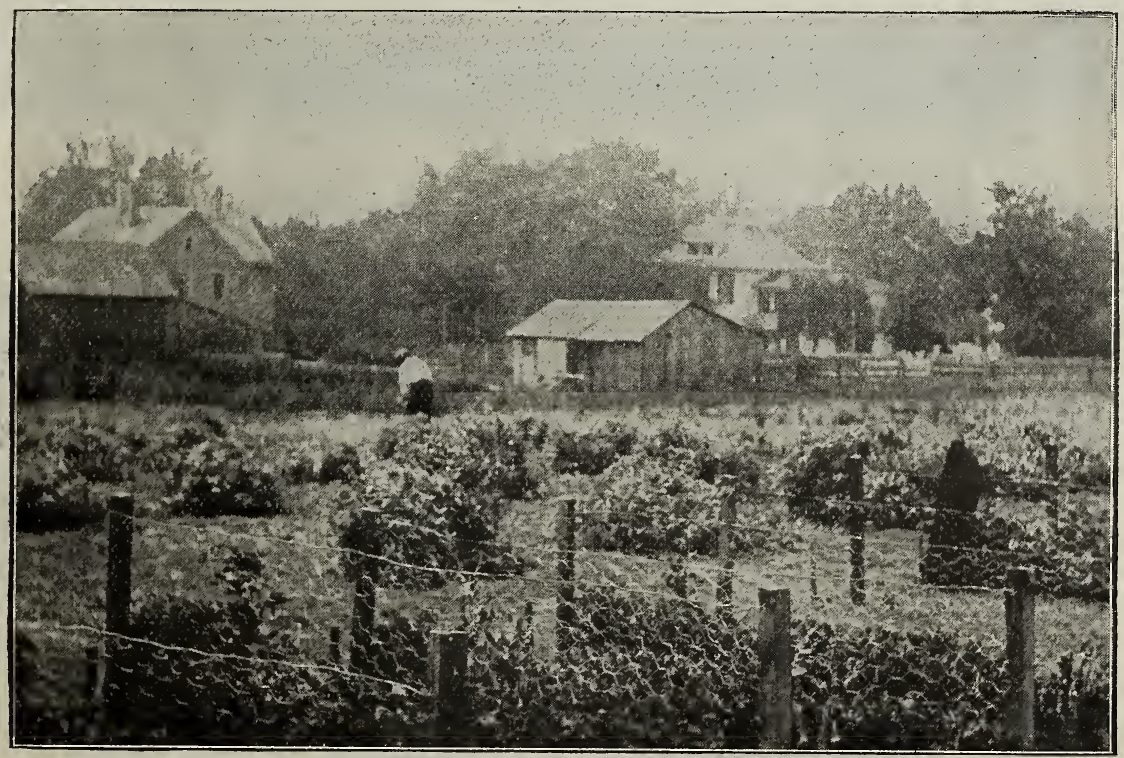

I HARVESTING PEAS FOR STOCK IMPROVEMENT AT COLUMBUS, WIS.

Mr. O. L. Daily, our Pea expert at work harvesting a block of podded stock of Alaska. That is, this crop is the third product of pea from a single pod - the first two crops were harvested by pulling the pods and shelling by hand so that only perfect seed would result. 


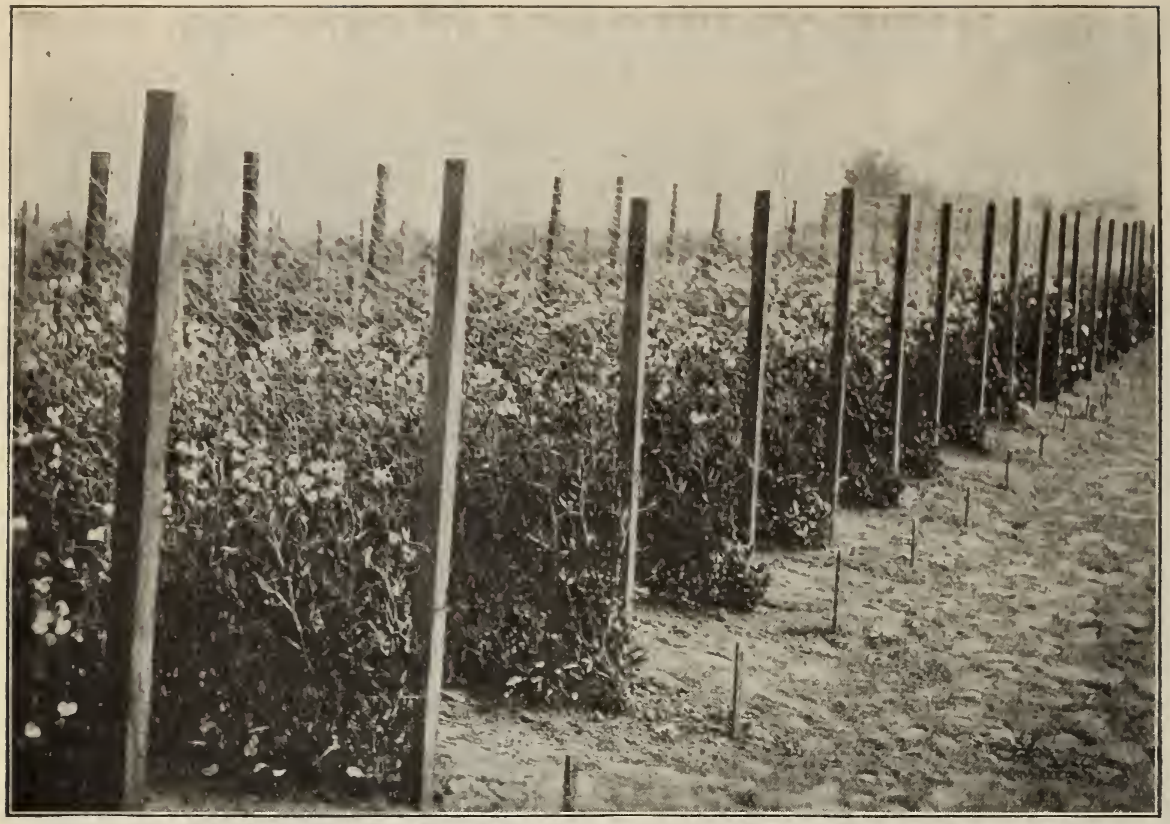

HORSFORD'S MARKET GARDEN PEAS IN BLOSSOM

\section{Our Stock Im-} provement Methods

T o p picture is a close view of Horsford's Market garlen peas in blossom.

The bottom vie w same row in foreground in full pod and tall late peas in the background.

There has been a great increase in the demand for seed Peas within the last few years and there scems to be no let up to it To meet this increased demand and to keep the seed stock up to standard is a problem not easily solved There has been a tendency in some quarters to mect the demand regardless of quality Our aim is to maintain the quality and then meet the demand.

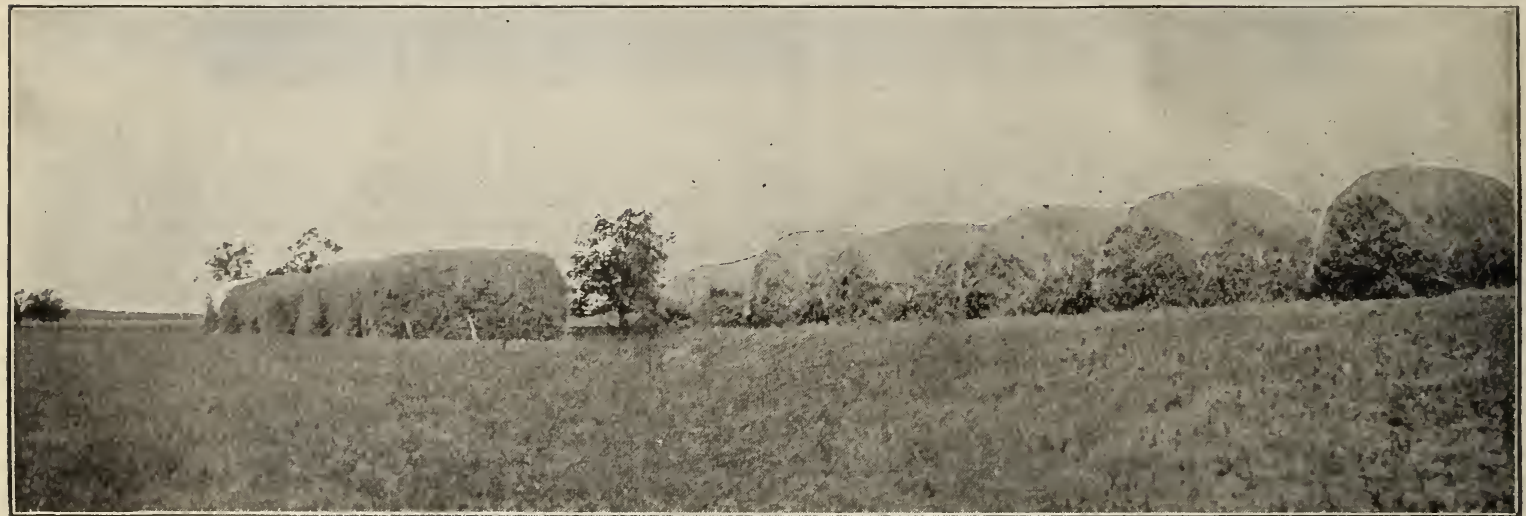

I3 STACKS OF PEAS; THE PRODUCT OF 45 ACRES. See Marginal Reading.

The picture in the center of the page is the crop harvested and stacked of 45 acres of peas, 13 stacks in all; of which the six in the first row are Alaska and the seven in the back row are Admiral.

These were grown at Columbus and thrashed in the neighborhood of 1,000 bushels seed.

It will take time to accomplish all that we have in view in the improvement of stocks. It can readily be seen however, that our facilities are of the best, that we are progressing alo $\mathrm{ng}$ the proper lines and that the results will be sure when they shall have been attained.

We gain knowledge as we proceed and one improvement in its accomplishment suggests ot hers. Our customers get the benefit of all this.

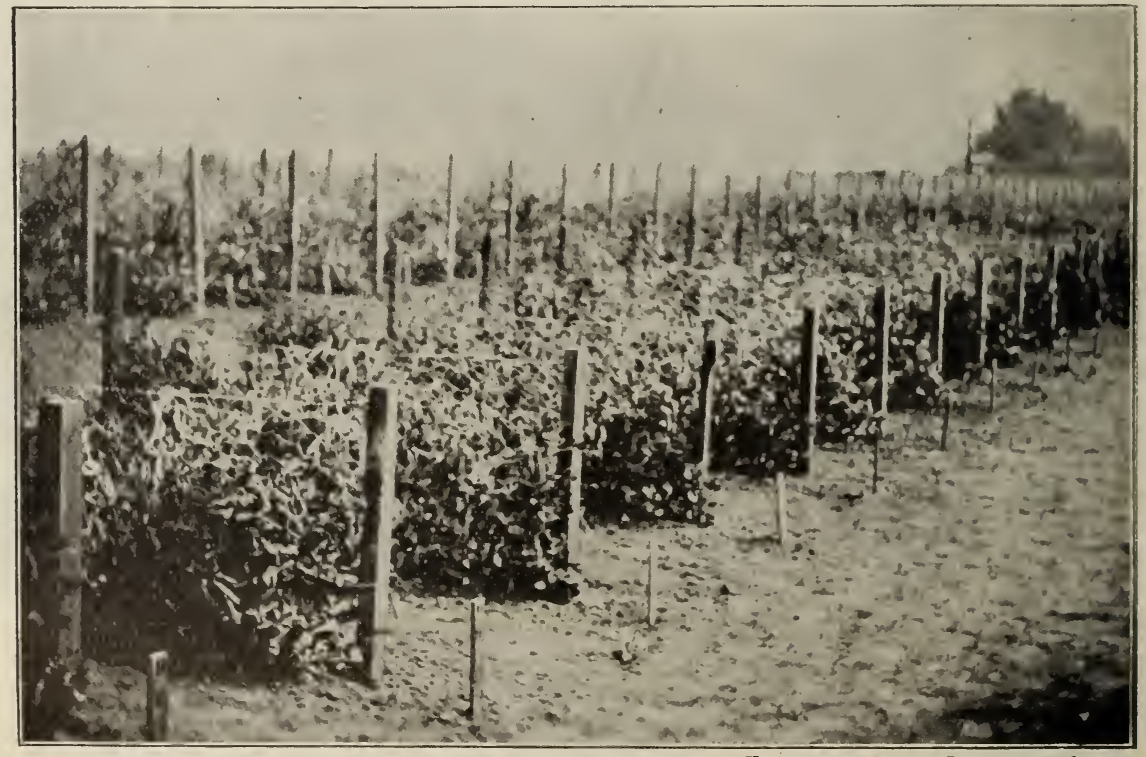

Foreground, Horsford's Market Garden Peas in Full Pod. Tall Late Peas in Background. 


\section{Hand Picking, Storing and Shipping}

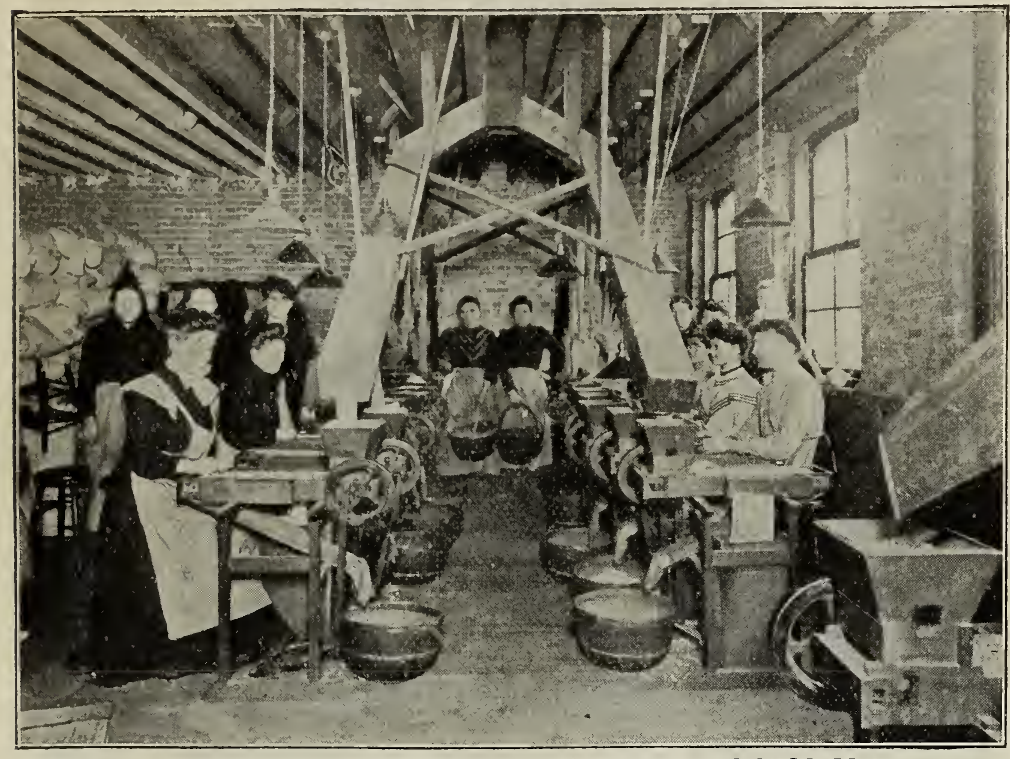

ONE SECTION OF PACKING ROOM AT OUR CHICAGO PLANT

Picture showing how we handpick all Peas, Beans and crops of like nature. This is one section of our Chicago Picking department. We have three just like this in this building. In these rooms we have picking machines operated by girls. These machines are run by foot power similar to running a sewing machine, and the beans or peas that are being picked move slowly toward the operator on a canvass belt, and the bad ones are taken out by hand and dropped into a box at each side of the machine. The good ones continuing on the canvass belt are dropped into a spout and pour from the machine into the basket as shown in the picture. As will be seen each machine is fed from above, for this purpose we use truck bins that hold about 30 bushels. These bins are filled from the mill, are run to the floor above the pickers, and allowed to run into the spouts, making a steady fall of beans or peas into the machine as needed. The women standing at the end of the aisle are they who inspect the peas as the baskets are being filled.

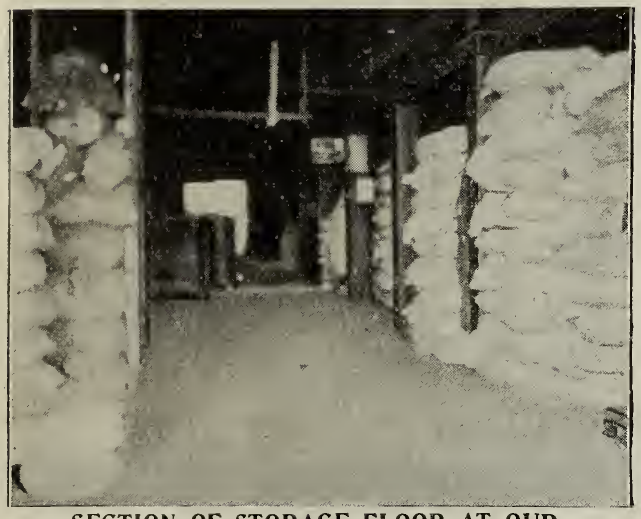

We mill all the seeds before they go to the pickers. For this purpose we have installed mills that take out all the split and dried up grain. These mills also separate the uneven sized grains and make the samples uniform and almost of merchantable appearance. The mill will not take out the discolored seeds however, and the hand picking done by the girls at the machines is a very necessary work. At the present writing we are installing at 218 West Kinzie Street, 10 doors east of our headquarters building, an additional lot of 60 picking machines. This enlargement is made necessary to keep up with our orders. This is the fourth addition to our picking facilities made within two years and indicate clearly the rapid strides we are making.

In the small view at the left we show a section through one of our Storage floors showing the clean cut and careful manner in which our Stock is piled away and cared for. We use a very considerable space for the storing of the large quantities of Garden Seeds that we handle. Our main storage of this class CHICAGO WAREHOUSE of Seed is at our headquarters warehouse.

Shipping and Small Order Room. We give a picture here of one of our packing rooms. It shows the packing department that puts up the smaller lots in order that they may be connected with the bulk goods that are made ready in other departments. Less than carload shipments are taken care of by the packers in this room, but nothing smaller than five pound lots of garden seed and bushel lots of Peas, Beans and Corn are handled by them, such lots being put up elsewhere and passed down to connect when needed. By this system we can get orders together in the quickest and safest manner. The proper labeling of seeds is a most important part of the seed business. No one can tell anything about seed by its looks. We have systematized things in our packing rooms so that errors are rare.

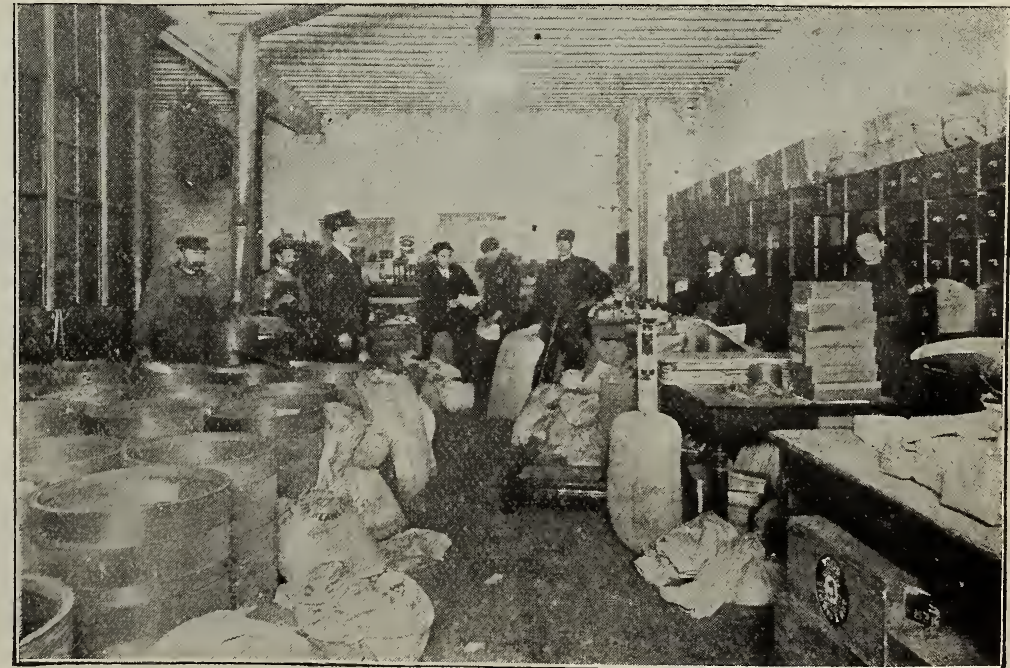

SECTION OF SHIPPING ROOM AT OUR CHICAGO WAREHOUSE 


\section{VEGETABLE SPECIALTIES}

Pheasant Eye Bean. A valuable new green podded variety. Vines hardy, sturdy, well leafed. Pods long, meaty, stringless and of excellent quality. Originated from plant found in Bountiful; it retains all the good points of that variety, with added symmetry of pod. It is early, productive and of exceptional value for market, garden or home use. The dry bean is slim, kidney shaped. Color white, splashed more or less at eye side with yellowish brown, which coloring also surrounds eye. The name, Pheasant Eye, was suggested by this coloring. We would advise all our customers to give this grand new hean a trial. Pkt. 10c.; $\frac{1}{2}$ Pt. 15c.; Pt. 25c.; Qt. 40c., postpaid. By freight or express at expense of purchaser, Peck $\$ 1.50$.

\section{Sweet Corn, Malakoff}

Sweet Corn, Malakoff. The earliest real Sweet Corn in existence; habits similar to Peep O'Day, with much better quality. The plant is very dwarf and usually produces three ears to every stalk; ears are short, $3 \frac{1}{2}$ to 4 inches; 8 rowed. Pkt. 10c.; Pt. 25c.; Qt. 45c.; Pk. \$1.50; Bu. \$5.50.

\section{Peep O'Day Sweet Corn}

Peep O'Day Sweet Corn. This new variety is claimed to be the Earliest Sweet Corn on Earth. It is of Minnesota origin and has been offered in the Minneapolis market from five to seven days earlier than any other wellknown kind in the trade. Ears five inches long perfectly formed, well filled. The corn is tender and sweet. We are very positive about the earliness of this variety, and that our customers will make no mistake in planting some of it for first early. Pkt. 10c.; $\frac{1}{2}$ Pt. 15c.; Pt. 25c.; Qt. 40c., postpaid. Pk. $\$ 1.25 ;$ Bu. $\$ 4.50$.

\section{THE NEWER WATERMELONS}

Success A southern variety which has become very popular with UCCess shippers. The fruit is uniformly large, nearly round, dark green, sometimes indistinctly striped with a lighter shade and has a thin and firm rind which makes it an excellent shipper; flesh bright red and of good quality. The vine makes a strong and vigorous growth. Pkt. 5c.; oz. 10c.; $\frac{1}{4}$ lb. 20 c. ; lb. 80 c., postpaid.

Tom Watson Originated near Augusta, Ga., a few years ago; made; shape long; color dark, deep green; no stripes; large-often times 50 to 60 pounds; two mellons to the vine; no ends, no necks to rot; better shipper than Rattlesnake; tougher rind; flesh deep red; seeds white, smeared with yellow. Pkt. 5c.; oz. 10c.; $\frac{1}{4}$ lb. 30c.; lb. $\$ 1.00$, postpaid.

Iceberg or Blue Gem One of the most popular market very extensively in the South for Northern markets, and is today the favorite variety with the watermelon growers of New Jersey, who supply the Philadelphia and New York markets. Pkt., 5c.; 0z., 10c.; $\frac{1}{4}=1 b ., 15 c . ; 1 b ., 60 c .$, postpaid.

PHEASANT EYE BEANS. Triumph It is a cross between Duke Jones and Kolb's Gem. It has former and the shipping qualities of the Gem; medium season, very prolific, deliciously sweet and of enormous size. It possesses all the qualities that go to inake up a desirable melon. Pkt., 5c.; oz., 10c.; $\frac{1}{4}=$ lb., 15c.; lb., 60c., postpaid. . Bluish cast melon and elongated; larger than Kolb Gem: far better eater and seller than Kolb Gem. Seed is white. Pkt., 5c.; oz., 10c.; $\frac{1}{4}=1 b ., 15 c . ; 1 b ., 60 c$., postpaid.

Bradford Similar to the famous Joe ings; long, color dark, with darker wavy bands, flesh melting and of excellent flavor. Very popular with southern growers to ship to northern markets. Pkt., 5c.; oz., 10c.; $1=1$ lb., 20c.; lb., 75c., postpaid.

Halbert Honey $\begin{gathered}\text { Equal } t \text { o } t \text { h } \mathrm{e} \\ \text { Kleckley }\end{gathered}$ of 20 inches oblong form, almost equally round at each end. Rind dark green. A most profitable seller in local markets, but not a good shipper. A number of planters who sell melons in near-by markets report that the new Halbert Honey will outsell any other variety. Pkt., 5c.; oz., 10c.; talb., 20c.; lb., 75c., postpaid.

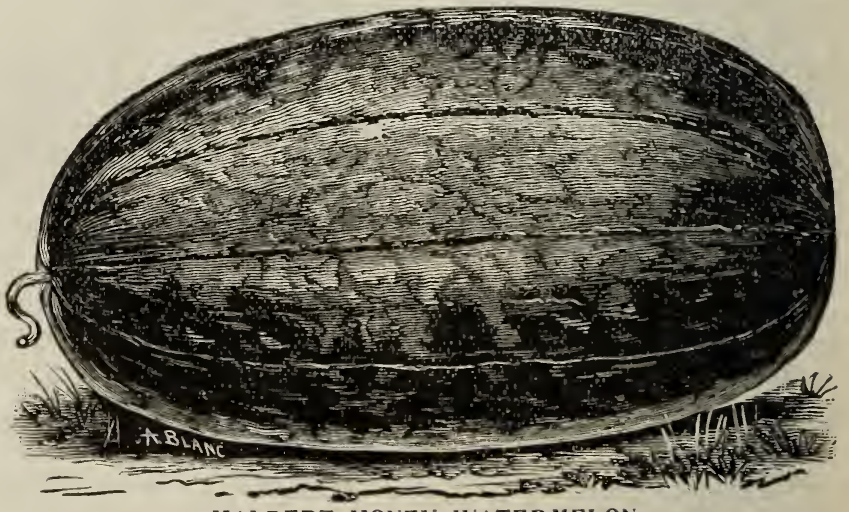

HALBERT HONEY WATERMELON. 


\section{VEGETABLE SPECIALTIES}

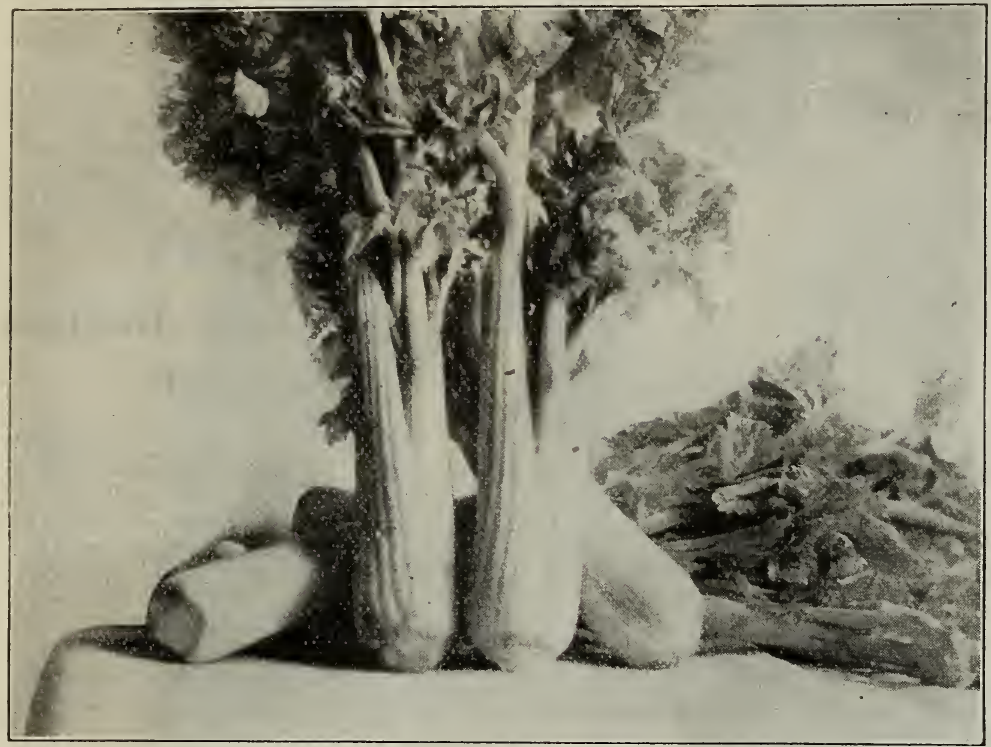

\section{Celery, Chicago Giant Self Blanching}

This new variety is meeting with increased sale every year and it will soon become a standard sort because of its extra earliness, large size and high quality. Such an expert as T. Greiner unsolicited calls it the most valuable white sort he has yet raised. It may be sown early without running to seed and produces large stalks early and of better quality than White Plume or Silver Self Blanching. Pkt., 10c., 0z., 30c.; $\frac{1}{4}$ lb., \$1.00; lb., $\$ 3.50$, postpaid.

\section{Radish, Sparkler White Tipped}

For out-door use during the hot, sumimer months, Sparkler Radish has the greatest endurance and the most continuous growth of any variety. It is a selection from Scarlet Turnip White Tip, and has for desirable qualities, just the right color, $\frac{1}{3}$ white, $\frac{2}{3}$ scarlet small tops, a small top root and rapid growth. Its color secures for it a high price and ready sale on the market. Its rapid growth makes a fine crisp radish where other varieties have lost shape and become pithy. Our stock is grown from transplanted roots,

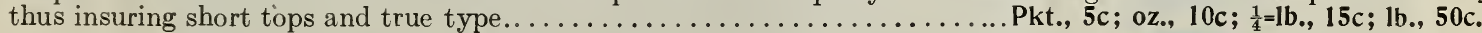

\section{Golden Bantam Sweet Corn}

A very early sweet corn with golden yellow grain, very tender and of excellent quality. The ears are eight rowed, six to seven inches long and of the medium size found most suitable for the table. The flavor is exceptionally rich and delicious. Our-stock has been very carefully selected. Height about four feet.

Prices..............................., 10c.; Pt., 25c., Qt., 40c., Pk., \$1.35, Bu., \$5.00

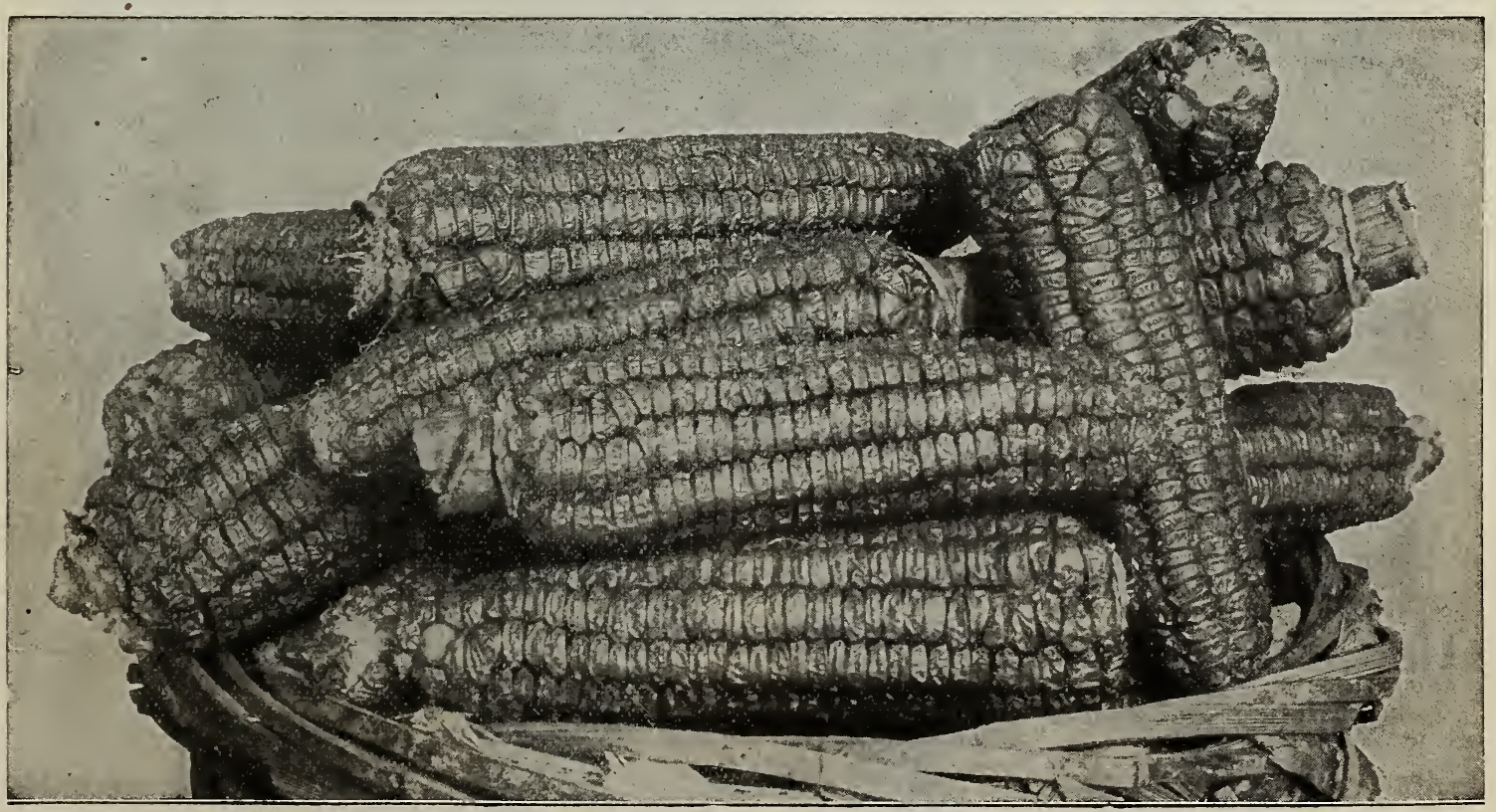




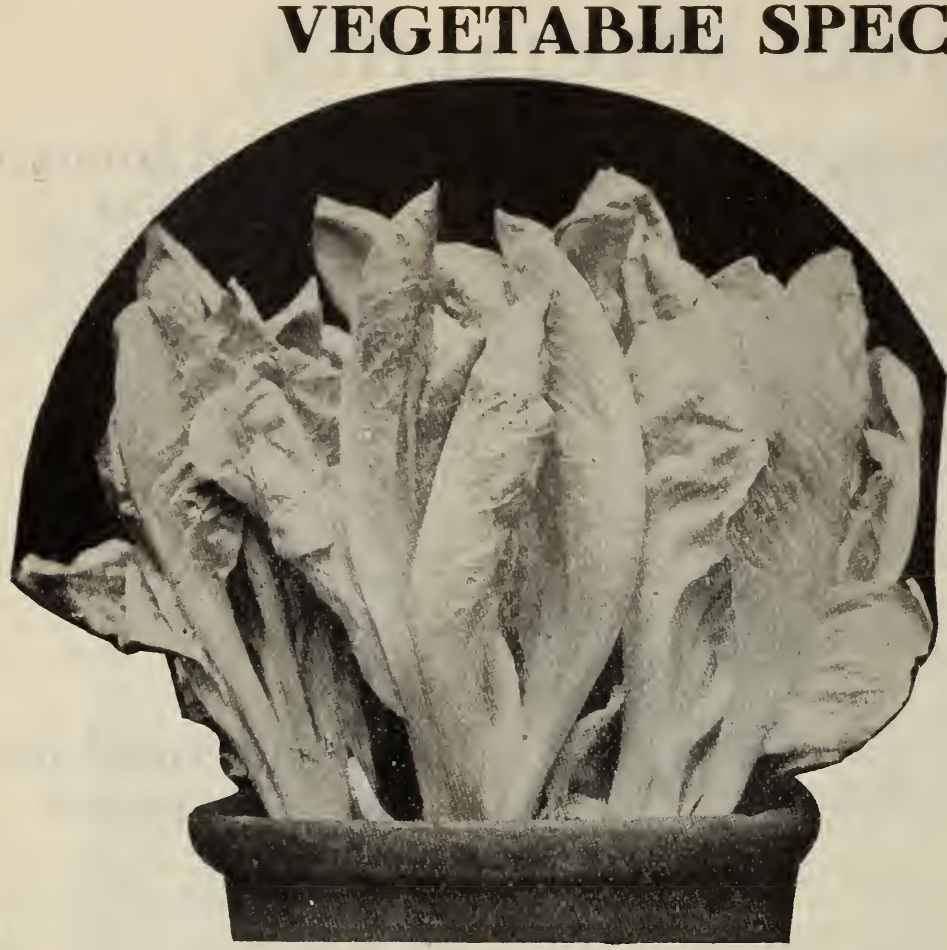

\section{Pepper}

\section{(Magnum Dulce)}

This is the largest American variety of Pepper. The fruits are of immense size, some growing seven inches in length, and four inches in diameter. The flesh is exceptionally mild, sweet and pleasant, so mild that when fried like egg plant it makes a most delicious and piquant vegetable for the table. For the maximum yield, it is desirable to pinch off the King flowers (the first ones to open.) These flowers usually make the largest peppers; however the yield of medium sized fruit is increased by such practice. Our seed is grown each year by the originator, and is very carefully selected. Pkt., 10c: 2 pkts., 15c; oz., 30c.

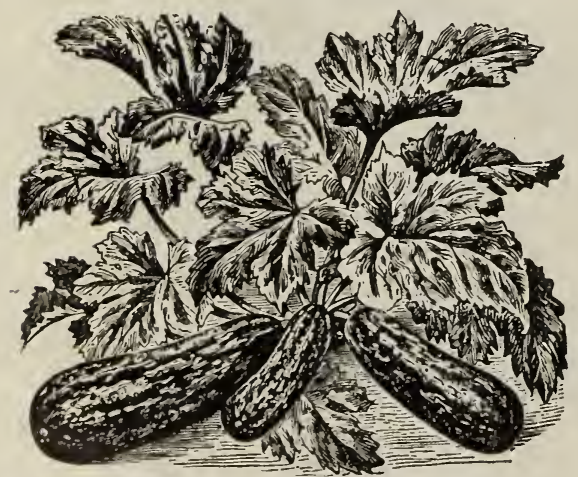

ITALIAN MARROW SQUASH

\section{Italian Marrow Squash \\ (Cocozella di Napoli}

A distinct variety of Squash of bush form. Fruit grows to a length of about 20 or more inches, with a diameter of 3 to 4 inches; skin smooth of a dark green color, marbled with yellow or with paler green. All through Italy, where this squash is grown, the fruit is eaten when quite young. Pkt., 5c.; 0z., 10c.; 1b. \$1,00.
Witloof Chicory. The principal merit of this variety consists in the width of its leaves and the large size of their ribs. When blanched, it forms the vegetable which the Belgians call Witloof. When properly grown and blanched it resembles a head of Cos Lettuce. Pkt. 5c; 0z. 15c; $\frac{1}{1}$ lb. 50c; lb. $\$ 1.50$.

\section{Long White Italian Squash} deners who supply the Italian trade. It is used in many ways and like the Italian marrow is a delicious vegetable when cooked in the proper manner Oz. 10c.; lb. $\$ 1.40$.

\section{Cardoon}

(Cardo)

Smooth Solid Cardoon. Grown from the mid ribs of the leaves which are blanched and used in the same manner as celery. The main root is also used and when cooked in a proper way, is excellent. Thorough blanching is necessary in order to bring out the delicacy of flavor possessed by the Cardoon. Oz., 10c.; lb., \$1.40.

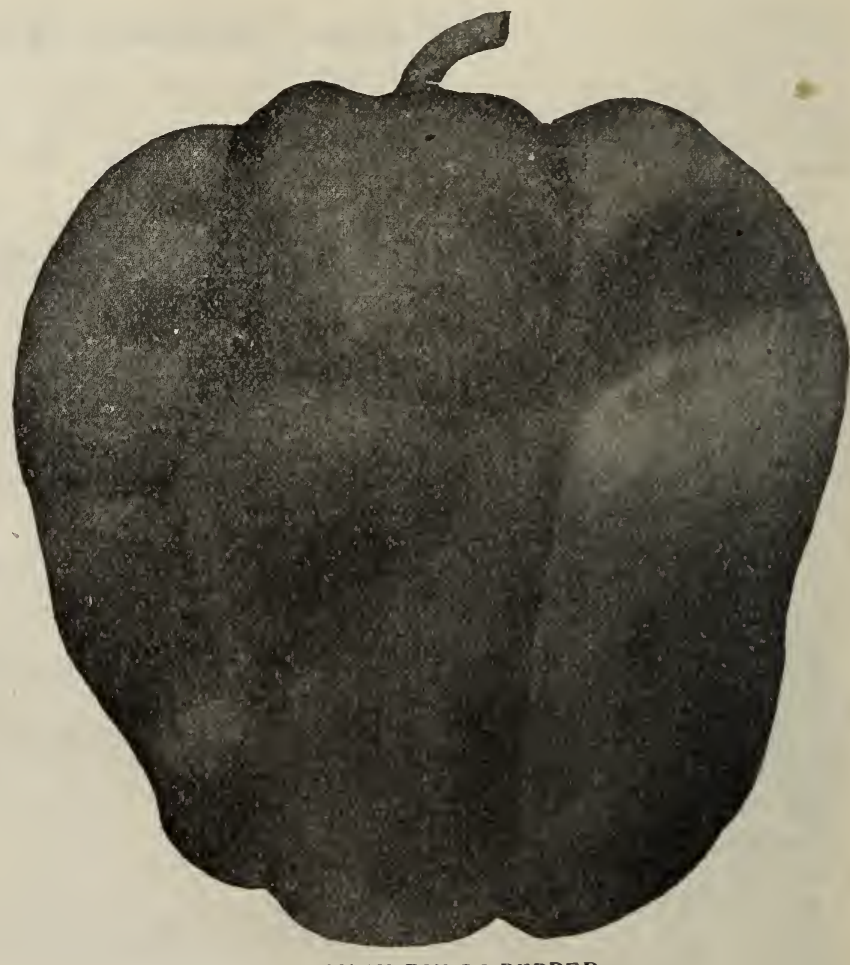

MAGNUM DULCE PEPPER
A variety much thought of by gar- 


\section{Leonard's Potlatch Peas}

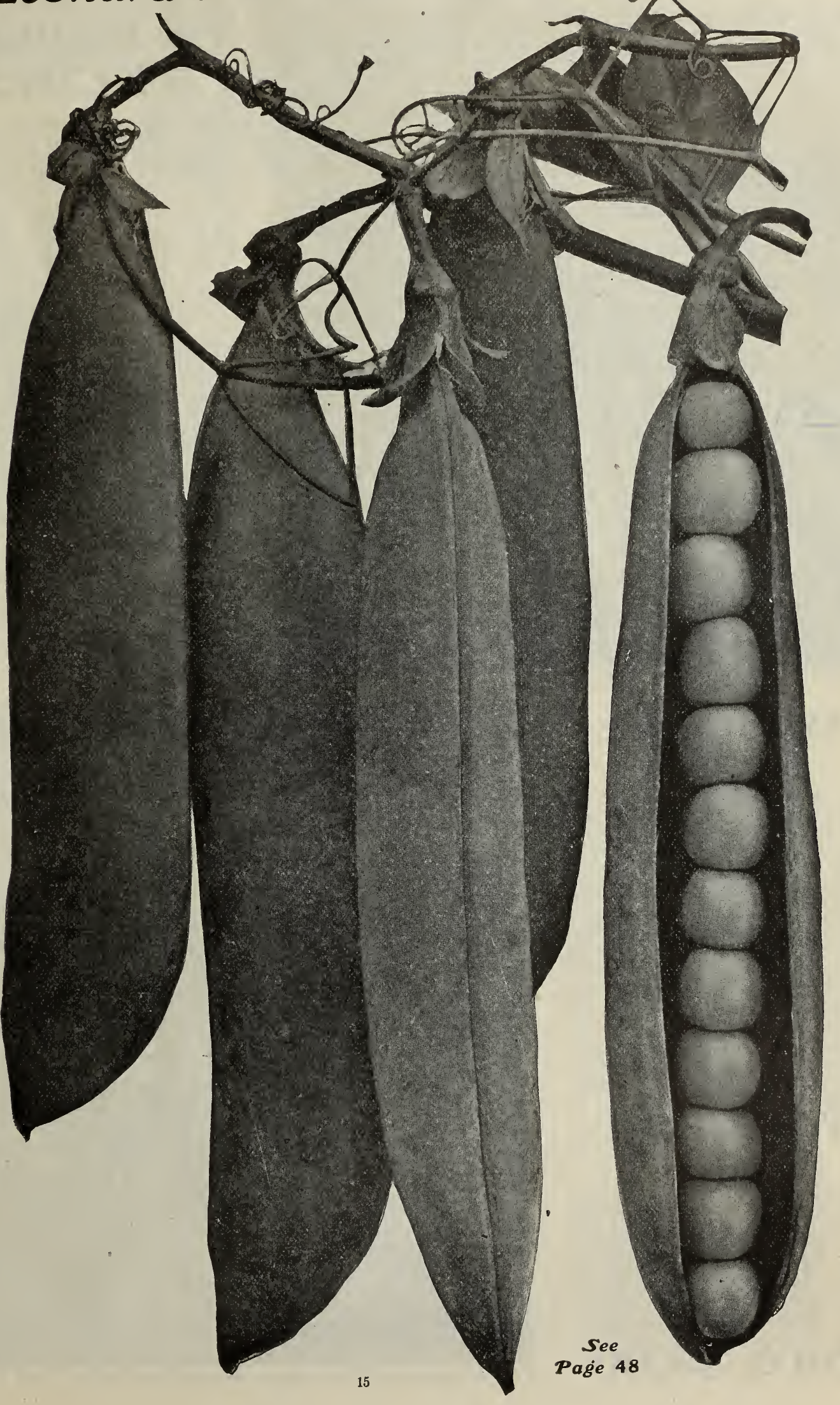




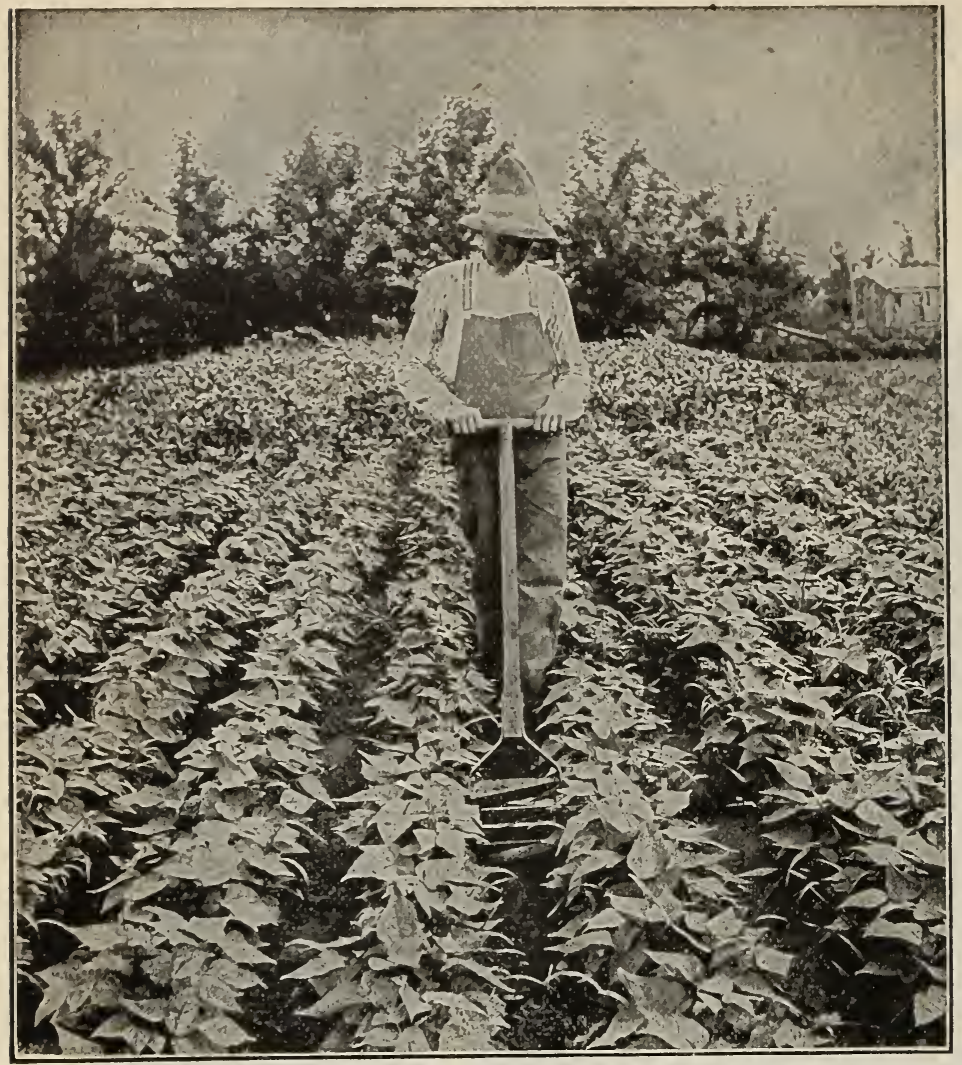

\section{TEE BARKER WEEDER}

THE BARKER WEEDER operates on the plan of a lawn mower It is to operate. It forms a dust mulch, cuts the weeds under the ground as well as the weeds out of the ground. It pulverizes the ground fine which holds the moisture to feed the plant. To appreciate the value of this tool you must take it to the field, you cannot judse it properly by looking at it. Take it out into the patch, pick out a piece of vegetation that needs weeding. Notice the work it does. Let your man work it. If you are not satisfied with it after gixing it a fair trial, you can return it Hundreds of the best market gardeners and onion growers have taken this tool to try and have kept it and bought more. It is a money saver. It costs thousands of dollars annually to weed onions and other market garden crops. The maest time saves the most money for the grower. EVERY CENT SAVED IS GAIN. The revolving blades of the Barker do far better work than the stationary bolted knives used on other machines. With the revolving blades of the Barker the surface of the ground is chopped, the weeds are cut, separated from the soil and thereby destroyed. With the bolted knives used on other weeders, the knife slips under the weeds oftentimes leaving them standing without disturbing the earth that hangs to the roots, and the weeds thus left start right in to grow again. You do not have to draw the Barker Weeder back after each forward motion like you do other hand wheel hoes. It is a steady, forward push like running a lawn mover. You can walk fast or slow, as best suits you. With the Barker you do the work better, quicker, and save yourself the extra labor of the see-saw motion that is necessary to do effective

Cultivating Webber Wax Beans with a Barker

\section{AS A DOUBLE MACHINE}

THE BARKER can be adjusted to work "Dn both sides of the row. What we call a "Double Six" has been found the best for this purpose. for this purpose are furnished without extra charge. The bolting together of the two machines is a very simple process and when desired they can be unbolted easily and used as single machines. Two 8-inch machines can be used in the same way where the rows are wide enough apart. For onion sets the double machine will pay for itself in on day's working. Double Machine is $\$ 10.00$. Plants can be cultivated oftener and hence matured earlier, with a greater yield, with this machine than with any other. In this way the machine can be made to pay for if several times each year.

If time is money and ease of doing work an object, you had better buy a Barker Weeder and Nulcher at double our price than take an old style, hand-push machine as a gift.

\section{THE BARKER 3 Sizes}

The Barker is made in three sizes: viz. 6 -inch cut, $8 \frac{1}{2}=$ inch cut, and 11 -inch cut Each machine is fitted up with leaf guards and tooth at tachment. The $8 \frac{1}{2}$-inch cut is market garden for onion sets and ordinary lettuce and crops that are planted in close rows. The 11-inch for crops that are Either Size Complete with all Attachments.

\section{Price, \$5.00}

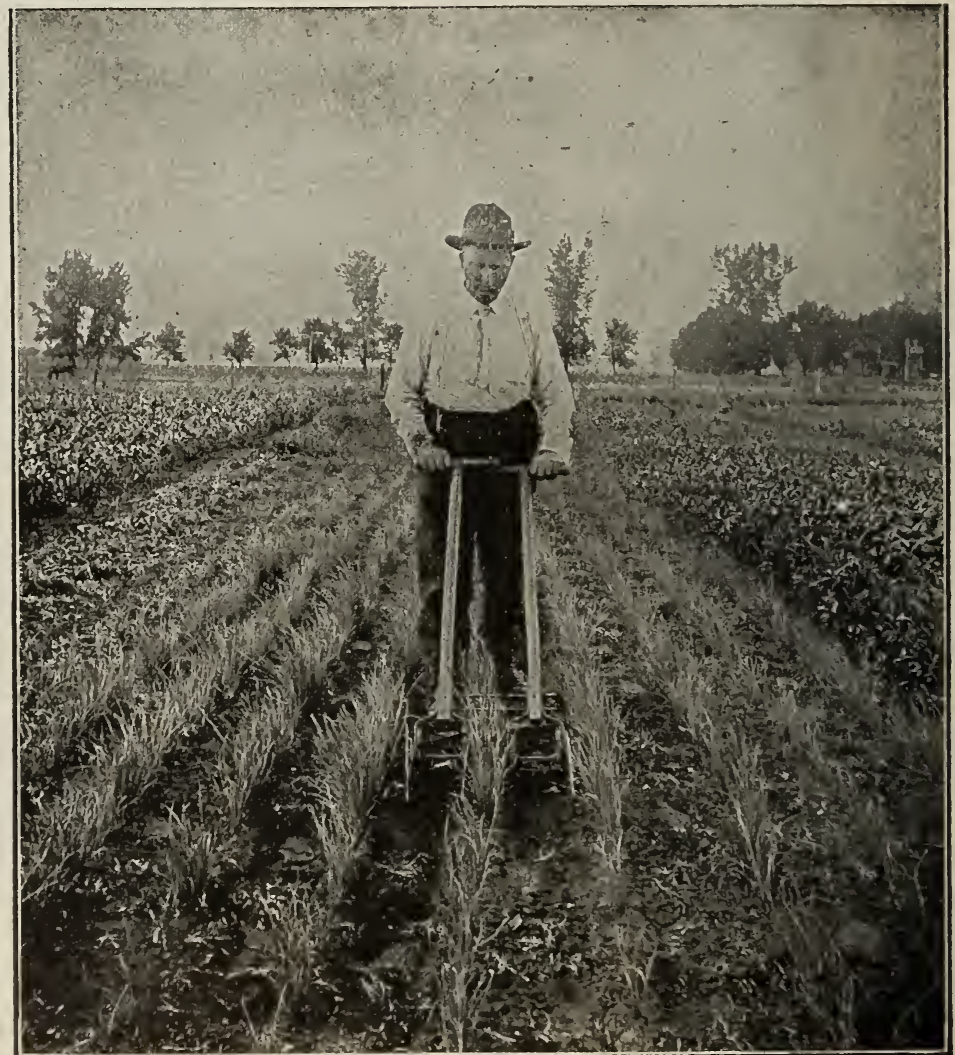

A Double Barker Consists of Two Single Machines Bolted Together. See Description 


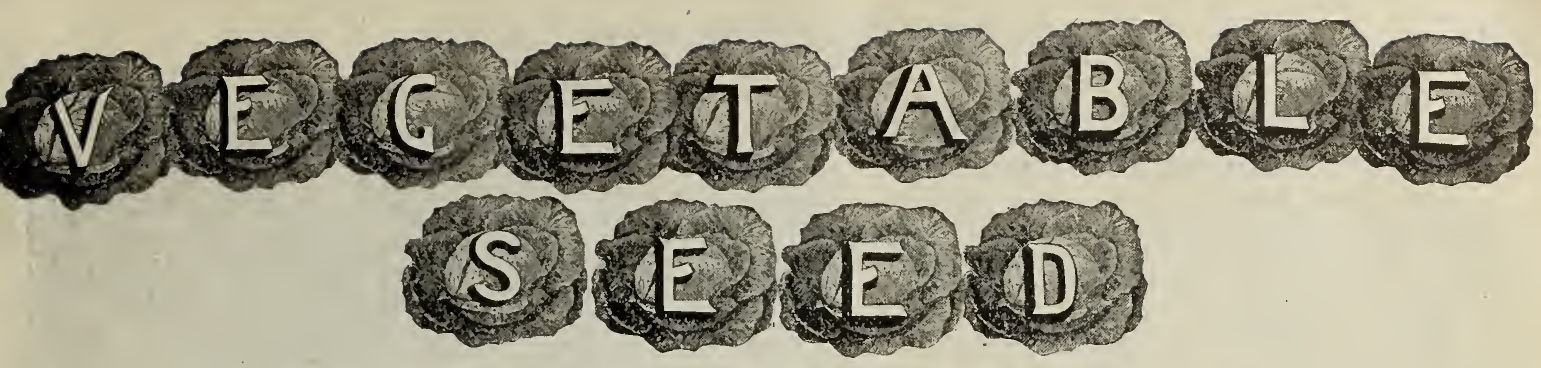

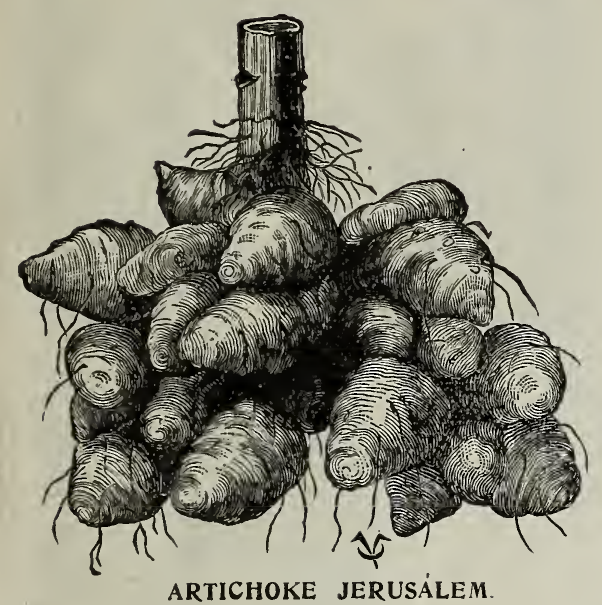

\section{ARTICHOKE}

Large Globe. Grown for the unripe flower heads, which are highly esteemed by epicures. Per oz., 25c.

Jerusalem. This variety is not produced from seed, but is cultivated for its tubers which are especially valuable for stock feeding on account of their fattening properties; they are well adapted to any soil where corn and potatoes can be grown. They are the best hog food known; a preventive of cholera and other hog diseases. One acre planted in Jerusalem artichoke roots will keep from 20 to 30 head of hogs in fine condition from October until April, except when the ground is frozen too hard for them to root, as they should not be dug in the fall, but the hogs turned into the field to help themselves by rooting for them. Three bushels of tubers are sufficient to seed one acre; cut to one eye; the same as potatoes, planting in April or May, in rows three feet apart and two feet in the rows, and cover about two inches deep. Price, lbs., 20c; postpaid; by freight or express, Pk., 60c.; Bu. $\$ 2.00$.

\section{ASPARAGUS}

(Asparagus Seed.)

Columbian Mammoth White. A new and entirely distinct variety, that produces shoots that are white, and remain white as long as fit for use. Oz., 5c.; $\frac{1}{4} \mathbf{l b}$., 15c.

Conover's Colossal. The standard variety; of large size, tender and of excellent - quality. Oz., 5c.; $\frac{1}{4}$ 1b., 15c.; lb., 50c.

Barr's Mammoth. The stocks are very large, frequently one inch in diameter, with few scales; the stalks retain their thickness completely up to the top of the shoots, and have close, round heads. Oz., 5c.; lb., 50c.

Palmetto. It is of very large size, even and regular in growth and appearance. It is a very early sort, and immensely productive and of the best quality. $\mathbf{0 z .}, \mathbf{5 c}$.; $\frac{1}{4}$ lb., 10c.; lb., 50c.

Giant Argenteuil. Is a selection from imported French Argenteuil stock. An improvement upon the original. In the south it is regarded as distinctly superior to Palmetto. One experienced grower says that Argenteuil is as much larger than Palmetto as Palmetto is larger than Conover. Pkt., 5c,; oz., 10c.; $\frac{1}{4}$ lb., 20c.; lb., 75c.

Bonvallet's Giant. Becoming very popular with large growers. Preferred by many over all other kinds. Pkt., 5c.; oz., 10c.; $\frac{1}{4}$ lb., 20c.; lb., 75c.

\section{ASPARAGUS PLANTS}

These prices do not include postage. If to go by mail, add at the rate of $50 \mathrm{c}$. per 100 for the 2-yea-old plants.

\section{WE DO NOT PAY POSTAGE ON THESE.}

Columbian Mammoth White. 2-year-old roots.

Conover's Colossal. 2-year-old roots.

Barr's Mammoth. 2-year-old roots.

Palmetto, 2-year-old roots.

Prices on any Variety of 2 -year=old Roots; Per 100, 75c.; Per 1,000, $\$ 5.00$.

Special prices on larger lots on application.

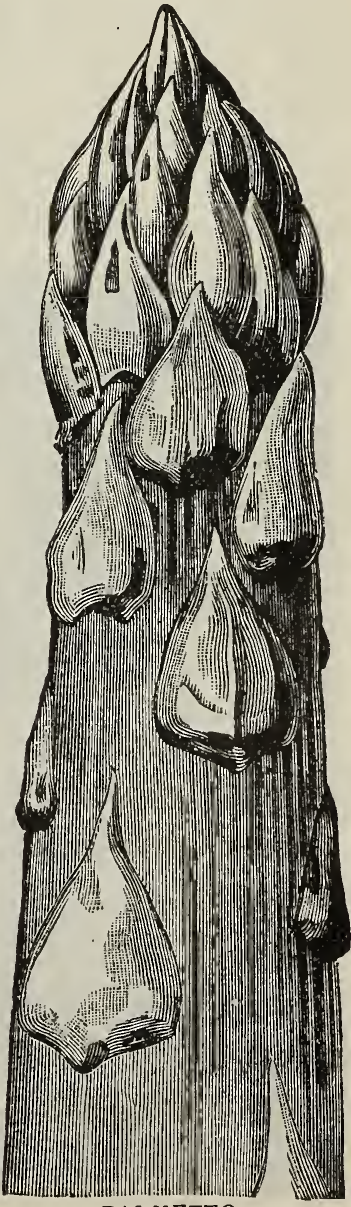

PALMETTO 


\section{BUSH BEANS}

\section{GREEN POD VARIETIES.}

Extra Early Refugee. Very much earlier than the Old style Refugee, or 1000 to 1 , being fit to eat in 48 days from planting. More dwarf and compact in growth, while the pods are round, solid, tender, and of excellent quality, suitable for table use, canning or pickling.

Refugee, or 1000 to 1 . The vines large, spreading, exceedingly hardy with small smooth leaves, very late and bear long cylindrical gren pods of excellent quality. Highly esteemed for late planting and for use as pickles.

Bountiful Beans. 'This new, green podded Bush Bean is a heavy cropper and very early, of fine shape, stringless, and good quality. Its hardiness and great productiveness make it one of the very best Bush Beans.

Tennessee Green Pod. This dwarf snap bean, although new to the Seed Trade, has for several years been grown in the South, and wherever known is freely spoken of in terms of highest praise. Vine prolific, foliage dark green with leaves large and crumpled. Pods long, flat, irregular in shape, bright green and of most excellent quality. Seed medium size, oval, flat, yellowish brown in color.

Extra Early Red Valentine. Hardy, pods light green, and semi-transparent, round and slightly curved. Succulent, prolific, and quite free from strings, continuing long in an edible condition 46 days from planting to first picking.

Long Yellow Six Weeks. The vine is large, vigorous, branching and productive, with large leaves. Pods long, straight, thick, flat in shape, green in color, of good quality when young and fair as they near maturity. Is realy for picking 45 days from planting.

Round Yellow Six Weeks. Very similar to Long Yellow Six Weeks as to vine; with pods shorter and much more thick and fleshy, about one week later, being ready for table 57 days from planting. Seed round, yellowish drab with a slightly darker marking about the eye.

Early Mohawk. One of the oldest and best known sorts. The pod is green, thick, flat in shape, of fair quality, developing a slight string as it matures. Is ready to pick 48 days from planting, and will resist a slight degree of frost very successfully.

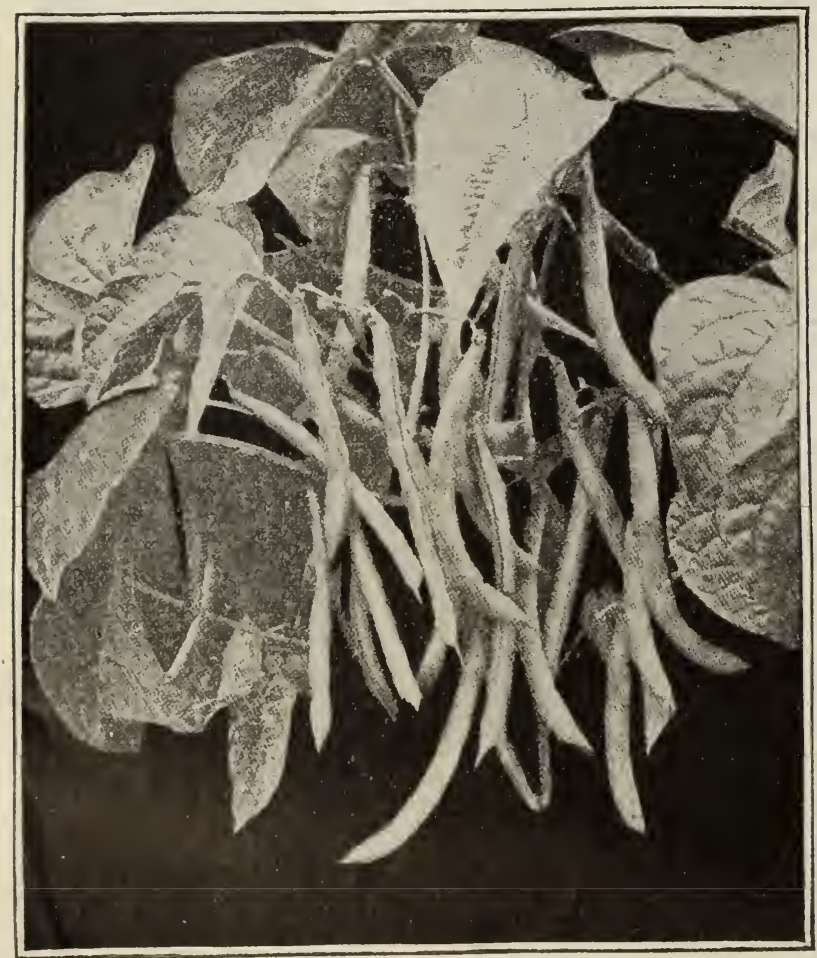

EXTRA EARLY RED VALENTINE.

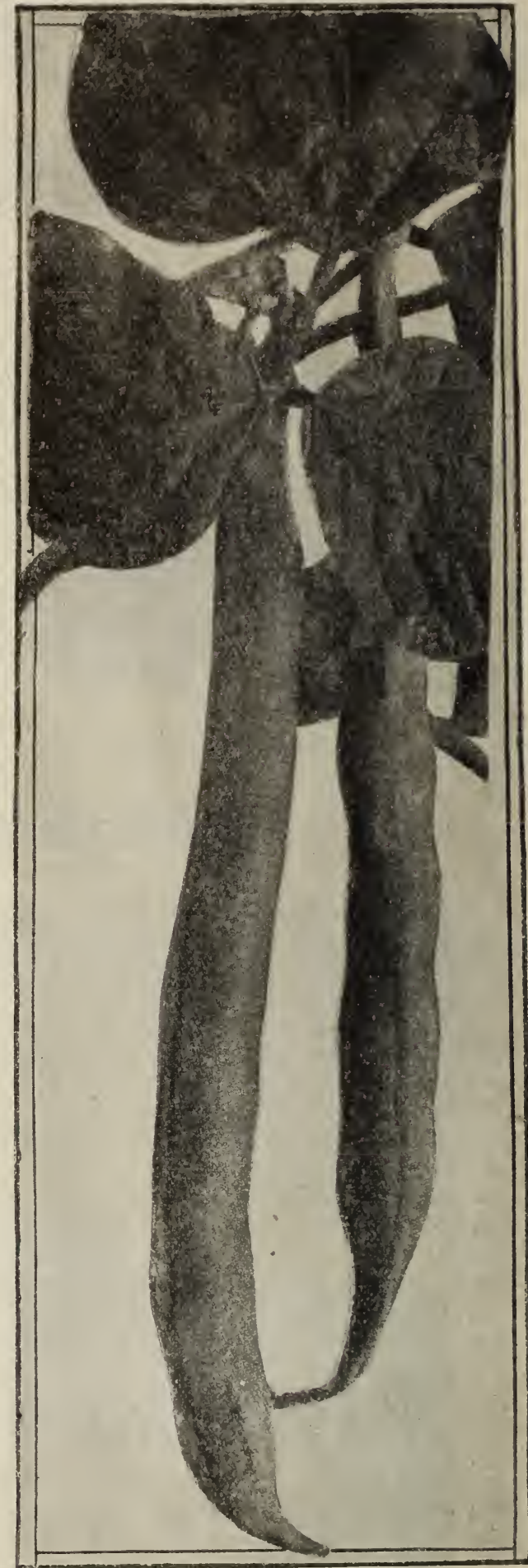

BLACK VALENTINE.

Black Valentine. This excellent variety is a great improvement over the old standard early Red Valentine, being one-third longer than that variety with pods perfectly round and straight and of excellent quality. It also has the additional advantage of being suitable for both early and late planting and is extremely hardy. It will withstand early and late frost, is an excellent shipper, a large yielder, and of very handsome appearance. 

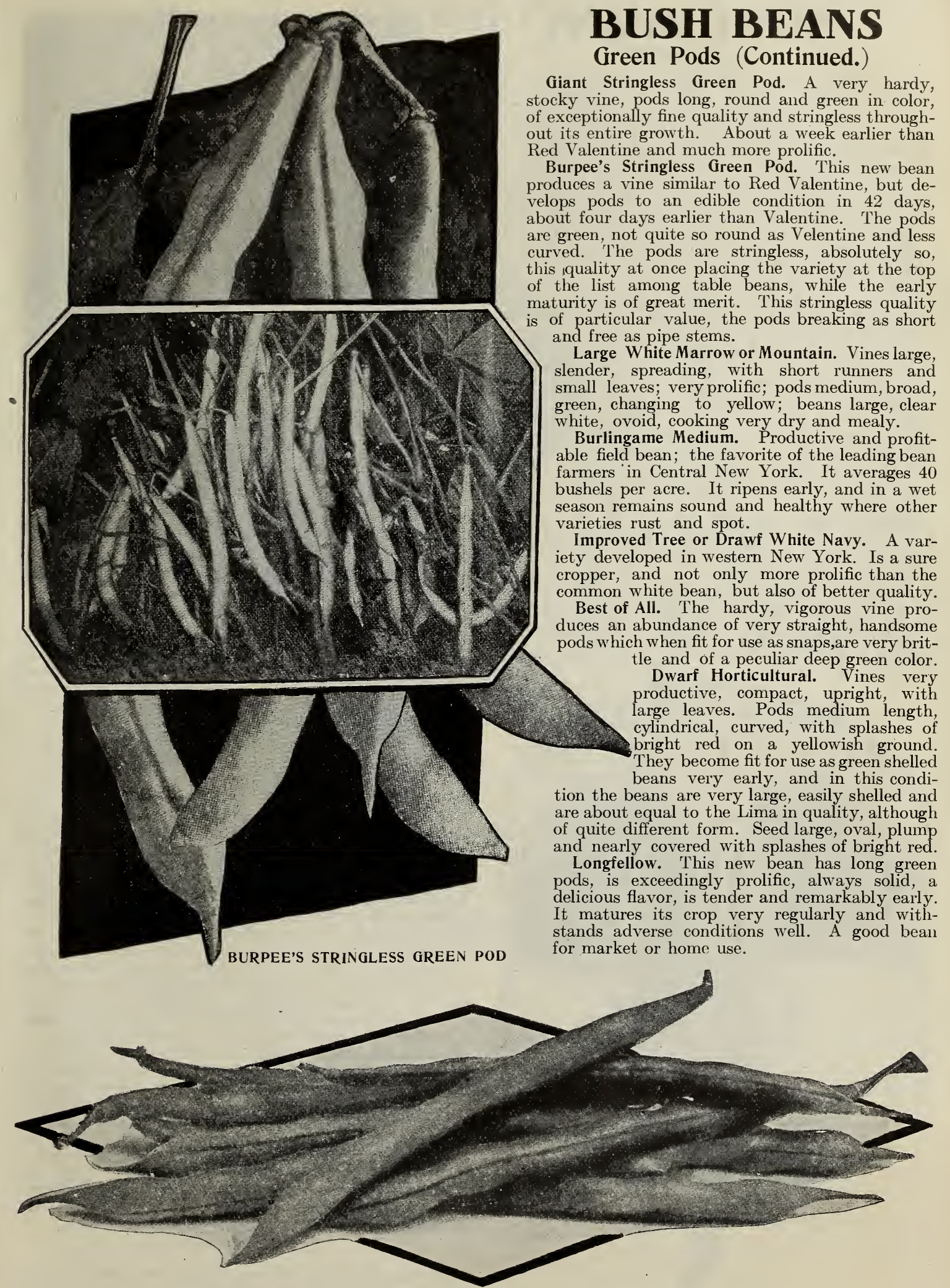

LONGFELLOW BEAN

BEAN PRICES, ANY GREEN POD VARIETY: Pkt., 10c.; 1=2 Pt., 15c.; Pt., 20c.; Qt., 35c. Postpaid. 


\section{BUSH BEANS}

WAX PODS

Davis White Wax. This bean is adapted alike for the canner, market gardener, shipper or' amateur. 'The dry bean is large, kidney shaped, and white in color, making it one of the best for cooking in a dry state. Pols are long, meaty, flat in shape, and of a beautiful yellow color and fair quality.

Curries' Rust Proof Wax. An excellent Wax Bean in every respect. Rust proof, tender, thick, flat pods of very good quality. Very little string in early stages, developing a little when nearing maturity. Fit for table use 47 days from planting.

Golden Wax. 'The old standard wax sort. Productive and early with yellow semi-round pods of good quality, ready to pick 49 days from planting.

Improved Golden Wax. Rust proof, an improvement on the old style Golden Wax. Pod is semi-round, yellow, of good quality and has no string. Ready for picking 47 days from planting.

Keeney's Rustless Golden Wax. Combines hardness and productiveness with fine quality. A strong growing bush variety of remarkable vigor and freedom from rust. The pods are meaty and well filled, thick, flat, when young and semiround later; a very desirable variety.

Detroit Wax. A distinct variety of recent introduction, which is worthy of a place in every garden. The waxy, yellow pods are produced in great abundance and the quality is extra fine.

Flageolet Wax. A large bush wax variety; seed large, purplish red; excellent as a snap bean, and in great favor as a dry shell bean.

Refugee Wax. A perfect Refugee with Wax pods. Pods long, round, and of a golden yellow color. One of the earliest, quality excellent and is fit for picking 57 days from planting. A very fine canning bean.

Wardwell's Kidney Wax. Hardy and productive, pods long, broad, thick, flat, and of a delicate waxy yellow, of ex-

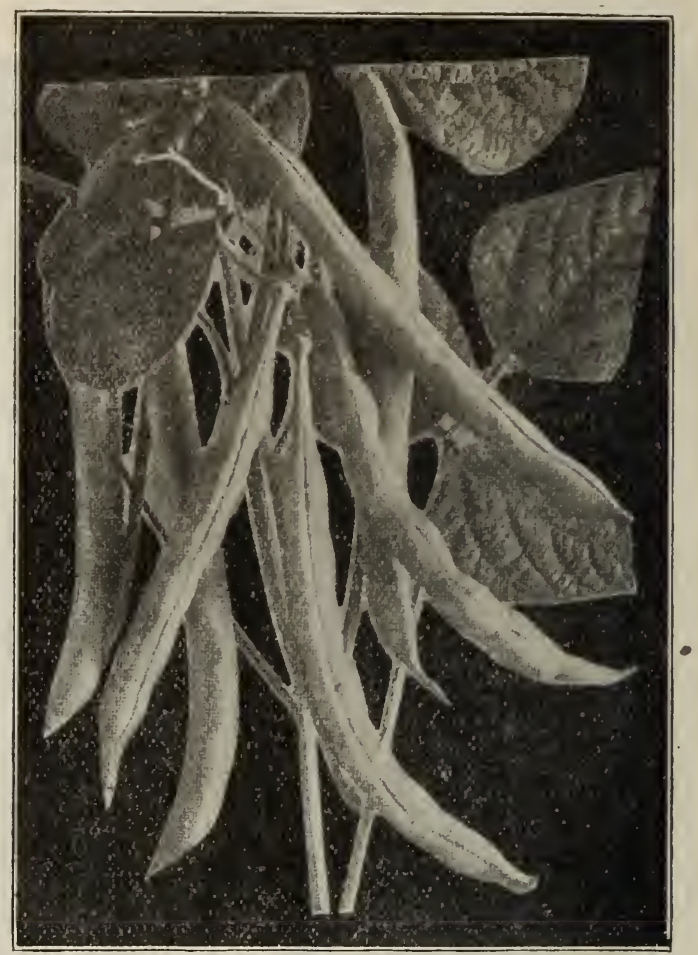

PENCIL POD BLACK WAX
Pllent quality and with no string in the early growth, ready for table 48 days from planting.

Pencil Pod Black Wax. Pencil Pod Black Wax grows a taller, stronger and more vigorous bush than the Improved Prolific Black Wax, which is one of its parents. The other parent is the Round Pod Refugee or Thousand

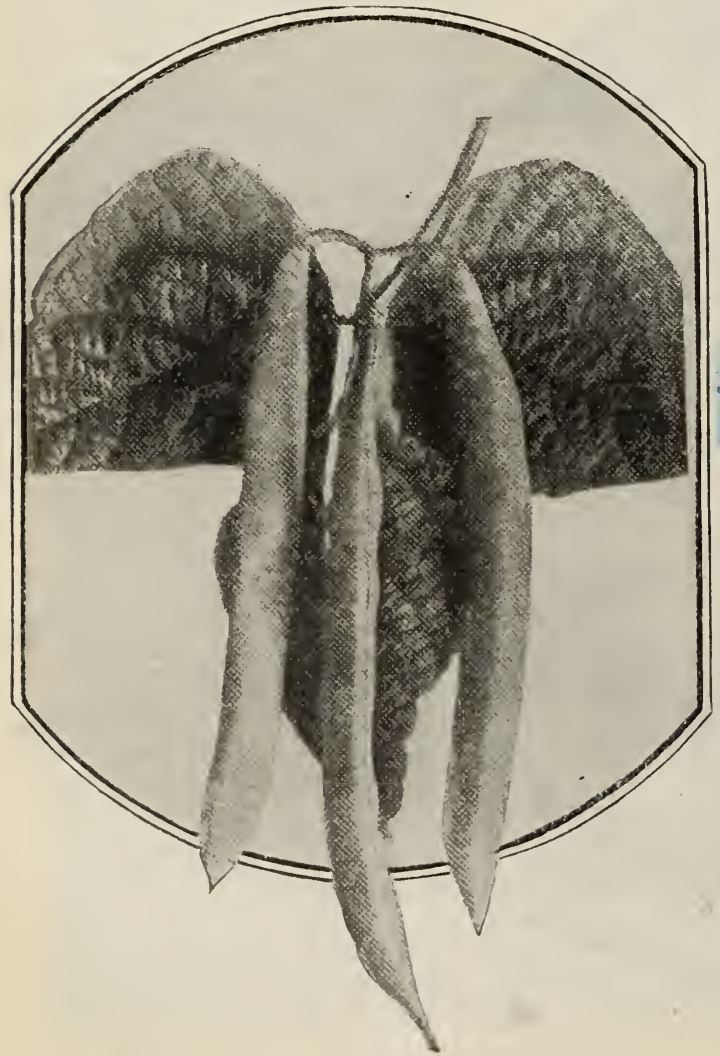

to One, and from this latter source the Pencil Pod Black Wax gets much of its vigor, hardiness and productiveness and its long, slender, straight, handsome pod, shaped very much like a pencil.

Prolific Black Wax. The old standard Black Wax Bush Bean. It is so good that it is worthy of special notice. The pods are round, brittle, of handsome golden yellow color, and of buttery flavor when cooked.

Leonard's Leopard Wax Beans. A new wax variety bearing long, straight, flat pods of a handsome clear yellow color. The vines are vigorous, standing well up from the ground, the foliage affording good protection for the pods.

Webber Wax Bean. A new Wax Bean of distinct character. This bean has been in the hands of a few Chicago gardeners for some years back. It originated in the best bean section of the Chicago gardening district. The gardeners who have had it gained an advantage over their competitors in better price and a readier sale as long as their crops of it lasted. It has been almost impossible to get any seed of this bean, the gardeners who possessed it keeping it to themselves so closely. Several years ago we secured a small lot which we have nursed along and this year we have enough seed to offer it in limited quantities to our customers. In our opinion there is a great future for this bean. We consider it of more value to the market gardener or amateur than any stock of wax beans that has as yet been sent out. The vine is strong, holding the pods well up. The pods are of an exceedingly bright yellow color, handsomer in this respect than any other wax bean; in shape they resemble Wardwell's wax but are rounder and more meaty. The color of the seed is yellow. The pods mature as early as Wardwell's and they can be gathered in bunches.

\section{BEAN PRICES}

Any Wax Pod Variety: Pkt., 10c.; $\frac{1}{2}$ Pt., 15c.; Pt., 20c.; Qt., 35c., Postage or Expressage paid by us. Peck and Bushe! prices vary. Write for them 


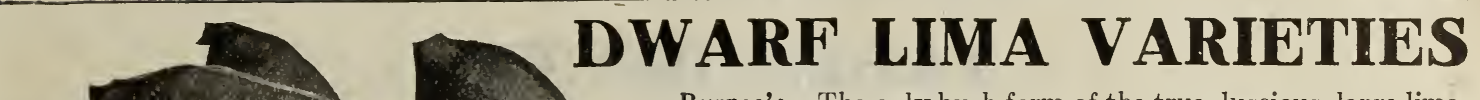
Burpee's. The only bush form of the true, luscious, large lima.
It is pronounced by all good judges as unquestionably the real Bush Lima. The bushes grow eighteen to twenty inches high, of stout growth and always erect. It is an immense yielder. Pkt. 10c; 1=2 Pt. 15c; Pt. 20c; Qt. 40c; Postpaid.

Dreer's. The true bush form of the chubby Dreer's or Potato Lima. The pods are heavy and thick. It is quite productive and of excellent quality. Pkt. 10c; 1=2 Pt. 15c; Pt. 20c; Qt. 40c.

Henderson's. This is a bush form of the small Seiva pole bean. It is the original bush form of the pole beans. It is the most productive of any, and on the whole is a vegetable of great merit. Pkt. 10c; Pt. 20c.

New Wonder. This gives the largest and best returns - a big crop from a small space-and is a decided improvement on the original type of Burpee's Bush Lima, being 7 to 10 days earlier, with pods 4 to 5 inches in length, each containing 3 and sometimes 4 large green beans of the finest flavor. The beans are of flat shape and fully equal in flavor to the famous Dreer's Bush Lima, so well and favorably known. Pkt. 10c; Pt. 20c; Qt. 40c.

Fordhook Bush Lima. Vines strong, erect and true Bush Lima growth, the bushes averaging 20 to 30 inches in height by 20 to 24 inches across the top. Foliage heavy and very dark green in color. The stalks that produce the blossoms are thrown out from the lateral and main stalks; the pods are borne in clusters of from 4 to 8 . The pods resemble Dreer's Bush Lima, but average more than double the size and contain from 3 to 5 beans to the pod. By far the heaviest cropper of any of the Bush Limas. It is from 4 to 6 days earlier than Dreer's or Thorburns' Bush Lima. Pkt. 10c; $\frac{1}{2}$ Pt. 15c; Pt. 20c; Qt. 40c; Postpaid.

\section{POLE BEANS}

Kentucky Wonder. Vines vigorous, climbing well, and very productive, bearing its pods in large clusters; blos-

soms white; pods green, very long, often reaching 9 to 10
lthough as they reach maturity they become irregular and FORDHOOK BUSH LIMA inches. Nearly round when young and very crisp, although as they reach maturity they become irregular and
spongy. Dry Beans long, oval, dun-colored.

Scarlet Runner. Height, 10 feet with dazzling scarlet flowers from July to October; both ornamental and useful. It is used either as a string or shelled bean.

London Horticultural, or Speckled Cranberry. Vines moderately vigorous, bearing short, broad pale green pods, becoming streaked with bright red as they near maturity. Beans large, ovate and splashed with red. Used either green or in the dry state.

Red Speckled Cut Short (or Corn Hill). This is the best sort to plant in hills of corn. A great cropper.

Dutch Case Knife. Vines moderately vigorous, climbing well and excellent for a corn hill bean; leaves large, crumpled, and pods very long, flat, green in color, becoming creamy white later. Beans broad kidney shaped, flat, and white in color.

Early Golden Cluster Wax. One of the very finest pole beans. Very early, being only a week later than Golden Wax.

White Creaseback. An extremely early Pole Bean. Vines small to medium and wonderfully productive. Bearing Pods in .clusters of from 4 to 12, and medium in length: An excellent shipper.

Lazy Wife. One of the most productive and easily gathered of the Pole Beans, hence its very discourteous name. A most excellent bean for the home garden.

Golden Carmine Horticultural Pole. Exceedingly early, and very robust in habit. Pods are very large, stringless and bright golden in color when young. As the pods approach full size they are mottled with an unusually bright carmine color. Quality excellent.

Early Jersey Lima. 10 days earlier than any other Lima. Recommended as a most profitable Lima Bean.

Dreer's Improved or Challenger Lima. This is a bean of rather peculiar shape, being thick and plump, rather than flat and oval.

King of the Garden Lima. The Old standard Market and family sort. The vine begins to produce pods at the foot of the Pole, and the bearing season continues until frost. Pods large, and well filled with Beans of Mammoth size.

Large White Lima. The large Lima is a general favorite wherever it can be cultivated, on account of its excellent flavor and productiveness.

Small White Lima, Carolina or Sieva. Vines vigorous with many short branches, so that they are sometimes grown without poles, very early and productive, bearing short pods, which are thin and eurved.

\section{POLE BEAN PRICES}

Any Variety. Pkt. 10c; 1=2 Pt. 15c; Pt. 25c; Qt. 40c; Post=paid. 


\section{TABLE BEETS}

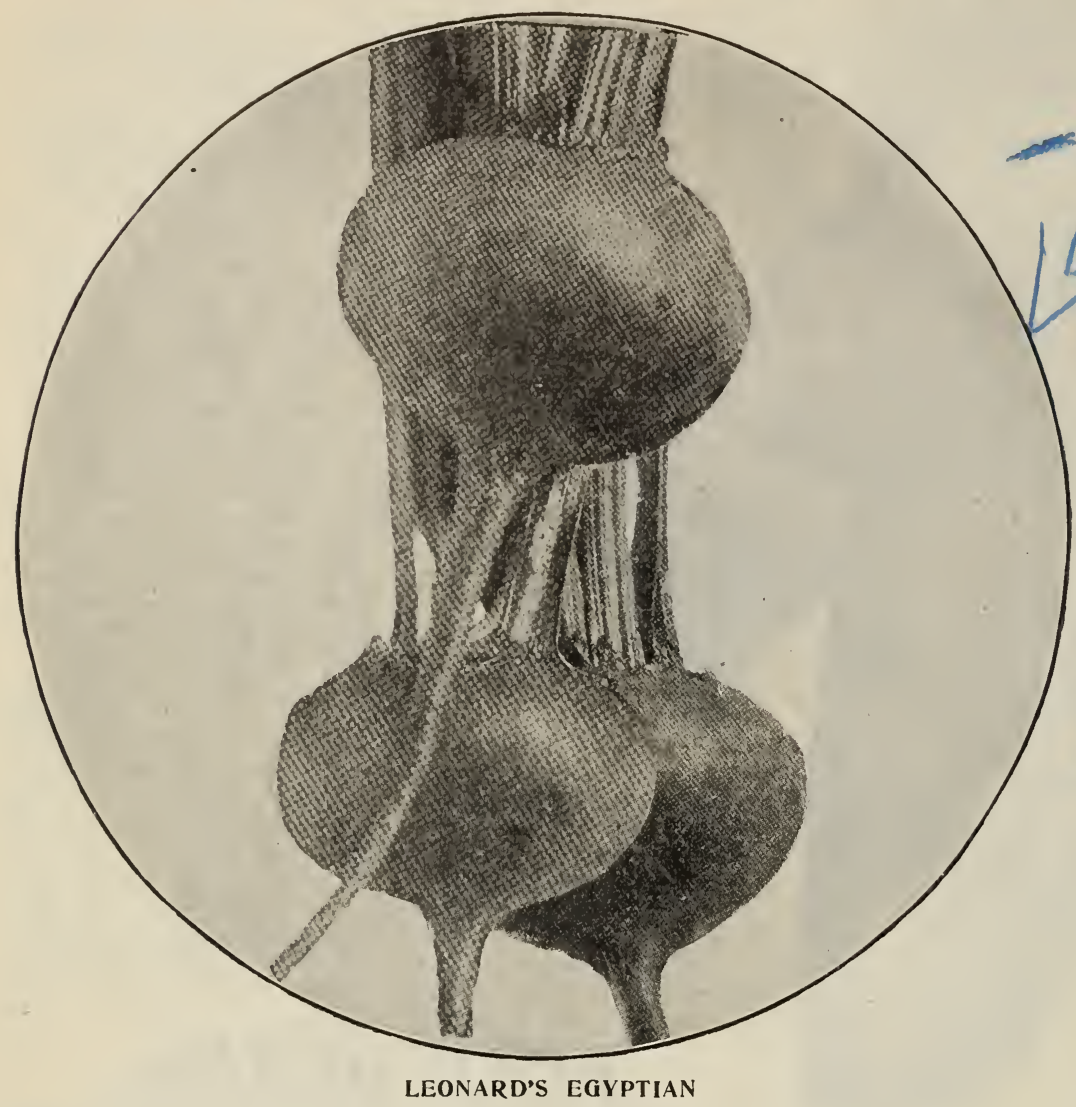

Early Eclipse. A choice early variety; well known and popular. Shape, globular; quality, good; color, light.

Early Egyptian. The well known early variety. Color, extra dark; shape, flat; quality, excellent.

(Leonard's Egyptian. This is the earliest and best bunching beet for market gardeners. It has been grown for many years by the gardeners of Chicago, and now they prefer it above all others? We grow the seed of this on our own farms near Chicago.

Lentz Extra=Early Blood Tur= nip. A favorite market-gardeners' beet around Philadelphia. Very early and sweet; ringed red and white.

Ruby Dulcet. Globe-shaped; in every respect a handsome market sort; small top, small tap-root:- skin and flesh deep, rieh, purplish crimson; finegrained, sweet and tender in all stages of growth.

Early Turnip Bassano. Tops large; leaf stems light red; leaves light green; roots large, flesh pink, zoned with white; very sweet and tender when young.

FOR ALL PRICES OF

BEETS SEE PAGE 23

Crimson Globe. This splendid variety has now been grown quite extensively in many sections of the country and the many good reports received from our customers indicate that it gives most thorough satisfaction. The root, is of medium size, generally about three inches in diameter, very handsome in shape, heing a little deeper than round, with a remarkably smooth surface. It has a very small tap-root. The very dark leaves are small and borne on slender stems; which occupy but a small portion of the root, but it is the exquisite tencierness of the flesh and the complete absence of any stingy or woody character that so thoroughly distinguish this beet. The interior color is very deep crimson throughout, but is ringed or zoned in a most beautiful manner, making it verv attractive in appearance.

Electric. A fine early beet. The color is dark crimson, with rings of a lighter red. Shape, round and smooth; leaves, small and compact.

Detroit Dark Red. Experience has shown this variety to be one of the best deep red turnip beets not only for market gardeners, but for home use. It is also one of the best for canning, making a strikingly handsome product. Its small, uprightgrowing tops, early maturing, and the splendid shape and color of the roots make it popular with every one who plants it. Tops small, upright-growing, so that the rows may be close together; leaf stems and veins dark red, blade green; roots very crisp, tender and sweet, and remaining so for a long time.

Edmand's Blood Turnip. Top small, spreading; ribs and short leaf stalks dark red; blade of leaf bright green, with wavy edge; root, dark red, interior color purplish red, with little zoning; crisp, tender, sweet, and an excellent keeper.

Crosby's Egyptian. This variety resembles the Egyptian only in its extreme earliness. The stock we offer is of a distinct vermilion color, which is very attractive not only in the beets as pulled, but after they have been cooked. They are also more spherical than the Extra Early Egyptian and we think of better quality. One of the best for early planting out of doors. It becomes fit for use sooner than any other variety, but it is not as well suited as the Egyptian for forcing in hotbeds or for transplanting.

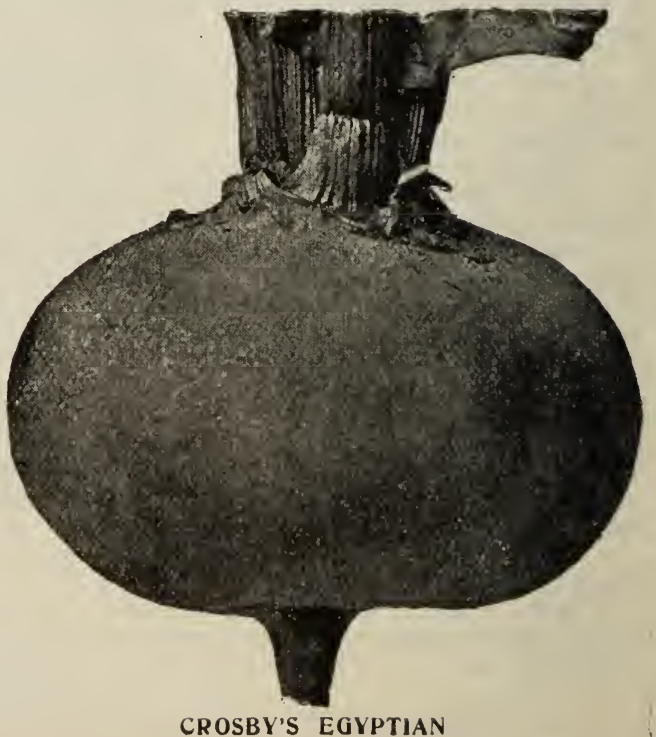




\section{TABLE BEETS (Continued)}

Early Turnip Bassano. Tops large; leaf stems light red; leaves light green; roots large, round, turnipshaped; flesh pink, zoned with white; very sweet and tender when young, but becoming woody and tasteless with age. An excellent sort to plant for use as "greens."

Arlington Improved. Early, deep round form; medium size; color, dark blood red; does not become stringy, but is sweet and tender at all times.

Half Long Blood. This is an entirely distinct variety and by far the best for winter use. The deep red roots are very symmetrical, two or three times as long as thick and always smooth and handsome.

Long Dark Blood. A standard late variety and keeps well through the winter. It is of good size, long, smooth, growing half out of the ground; with few or no side roots. Skin dark purple, almost black; flesh dark red, very tender and sweet.

Swiss Chard or Sea Kale Beet. Although little known in America, this vegetable is worthy of a place in every garden. The leaf and the leaf stems are the parts used and they are much superior to those of other beets to use as greens. Later in the season the broad, flat, beautiful, wax-like leaf stems are cooked as a salad or pickled.

\section{TABLE BEET PRICE LIST.}

Leonard's Egyptian,

Edmand's,

Early Bassano,

Crosby's Egyptian,

Bastians,

Electric,

Early Eclipse,

Crimson Globe,

Half Long Blood,

Blood Turnip,

All the uniform price by mail postpaid. Pkt., 5c.; oz., 10c; $\frac{1}{4}$ lb., 20c.; lb., 75c. By freight or express not prepaid, 5 lbs., $\$ 3.00 ; 10$ lbs., $\$ 6.00$.

\section{STOCK BEETS}

Leonard's Improved Mammoth Long Red. The largest and most productive variety. Immense crops can be grown from it.

Norbiton Giant Long Red. Very large, excellent variety for feeding stock. A heavy cropper in deep soil.

Yellow Globe. Globular shaped roots. More productive than Long Red in shallow soil. Very nutritious and a good keeper.

Golden Tankard. Shape cylindrical, color deep rich yellow, flesh yellow circled with white. Unequaled for feeding stock.

Orange Globe. We think this one of the best varieties of mangel wurzel grown for stock feeding.

\section{SUGAR BEETS}

Vilmórin's Improved Sugar. In general, the most desirable beet for the factory is the one containing the largest percentage of sugar.

Klein Wanzleben. A little larger than Vilmorin's Improved, yielding from twelve to eighteen tons per acre, and containing about the same amount of sugar. It grows below the surface, and the green leaves are rather large and spreading, with wavy edges.

Lane's Imperial Sugar. Good for making sugar, also stock feeding. A hardy and productive sort. Yields fourteen to sixteen tons per acre, and contains about 16 per cent. of sugar.

Bastian's Early Blood Turnip. Tops small; stems purplish-pink; leaves bright green; roots with medium sized tap, turnip-shaped, bright red. Flesh light purplish-pink, zoned with white; crisp, tender, very sweet and of good quality.

Dewing's Blood Turnip. Tops medium sized; leaf stems and veins dark red; leaves green; roots dark red, turnip-shaped.

- Columbia. Round and smooth, with deep red flesh; early and very tender.

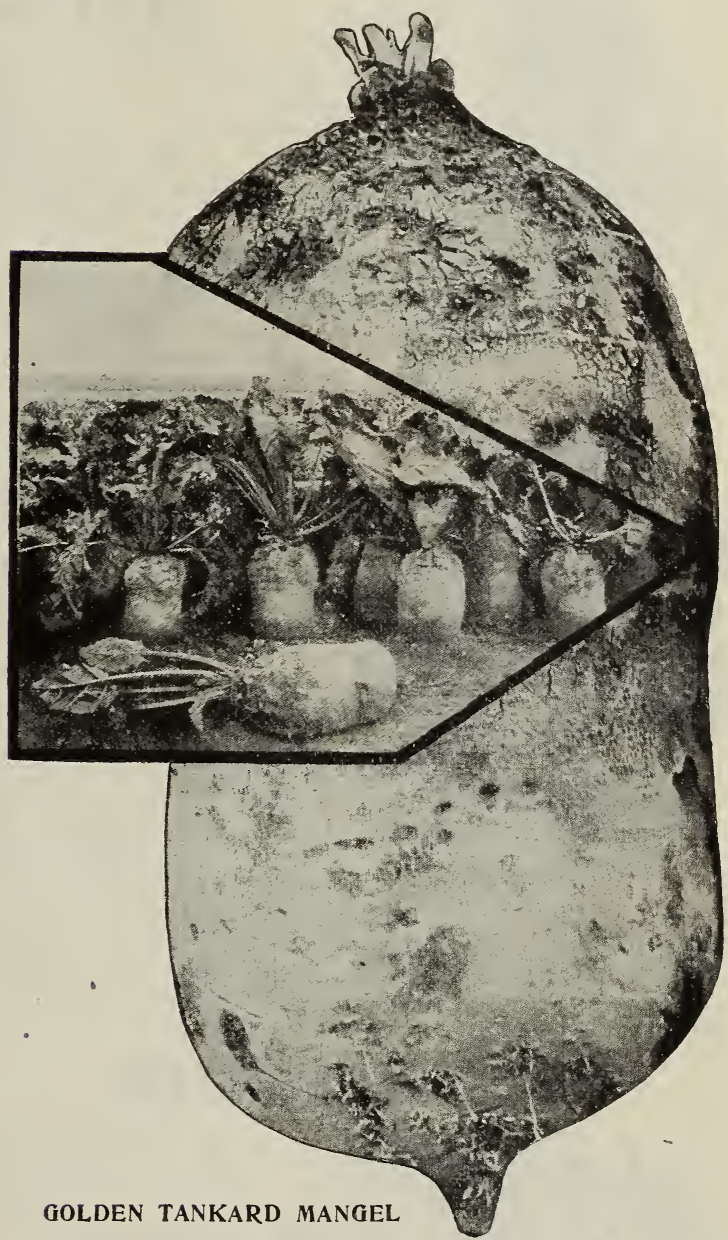

Giant Half=Sugar. This unites the large size of the mangel with the greater feeding value of the sugar beet. The roots average ten to twelve inches, and the outline is that of a broad thick wedge. The upper portion is of a soft bright pink, shading lighter toward the bottom where the lower portion for about onethird the length is white.

\section{PRICE LIST-STOCK AND SUGAR BEETS.}

Leonard's Improved,

Norbiton Giant,

Yellow Globe,

Golden Tankard,

Orange Globe.
Vilmorin's Sugar Beet

French Veryrich,

Lane's Imperial, Giant Half=Sugar,
Klein Wanzleben,

All at the uniform price, postpaid. Oz., 5c.; lb., 35c.; 5 lbs., $\$ 1.50$.

Five Pounds Will Seed One Acre.

By freight or express at purchasers' cost for trans= portation; any variety of Mangel or Sugar Beet. 10 Ibs., \$2.50; 25 lbs., \$5.00; 100 lbs., \$20.00. 


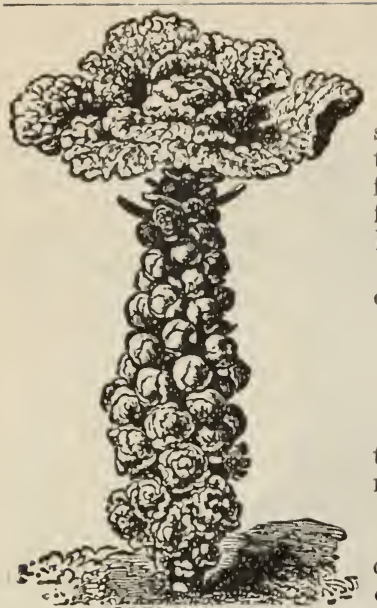

\section{BROCCOLI}

Broccoli. Nearly allied to the cauliflower, but more hardy. 'The seed should be sown in this district in the early part of May, and transplanted in June; further south the sowing should be delayed until June or July, and the transplanting accordingly from Angust to October. In parts of the country where the thermometer does not fall below 20 or 25 degrees broccoli may be had in perfection from November until March. It succeeds best in a moist and rather cold atmosphere.

White Cape. Heads medium size, close, compact, and of creamy white color. One of the most certain to head. Pkt., 10c.; oz., 40c.; 1 lb., $\$ 1.50$.

Purple Cape. Differs only in color. Pkt., 10c.; 0z., 50c.; $\frac{1}{4}$ lb., $\$ 1.75$.

\section{BRUSSELS SPROUTS}

Brussels Sprouts. 'This is one of the best vegetables for winter use, producing from the axils of the leaves an abundance of sprouts, resembling small cabbages, of excellent, mild flavor:

Tall French. Very fine. Pkt., 5c.; oz., 15c.; $\frac{1}{4}$ lb., 60c.; 1b., \$2.00.

Dwarf Improved. A variety producing compact sprouts of excellent

BRUSSELS SPROUTS

\section{CHERVIL}

Chervil. A hardy annual worthy of more general use for flavoring and garnishing. The curled variety is even more beauti-

ful than parsley.

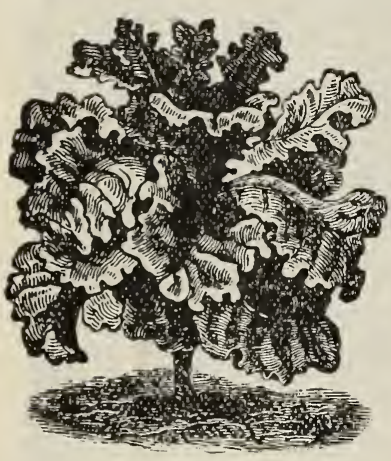

COLLARDS Culture-Sow in early spring in rich, well prepared soil, and when plants are well established transplant to about one foot apart.

Curled. Greatly superior to the old plain variety, being earlier, more handsome, and having fully as fine perfume and flavor. Pkt., 5c.; oz., 10c.; 2 oz., 15c.; $\frac{1}{4}$ lb., 25c.; lb., 75 c.

\section{CHICORY}

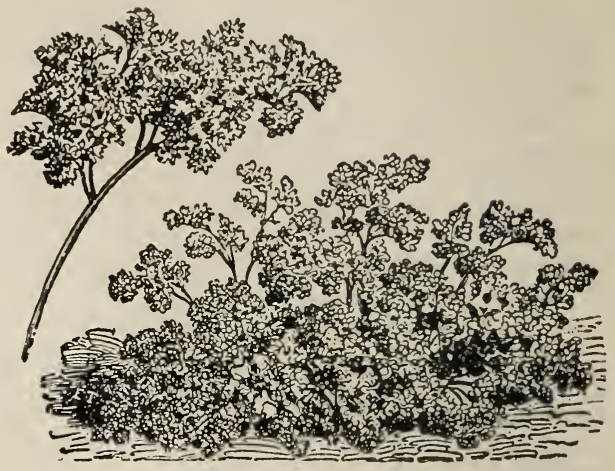

CHERVIL

Large=rooted, or Coffee. Our stock is the improved type, with very much larger, smoother, whiter and proportionately shorter roots than the old kind. The dried and prepared roots are used quite extensively as a substitute or adulterant for coffee. Soy the seed as early in the spring as the ground can be prepared, in a rather light, moderately rich soil, in drills fifteen inches apart for garden, and two to two and ore-half feet for field culture. When the plants are sufficiently large, thin to four to six inches apart in the row. Keep clear of weeds, and in the fall dig the roots, slice them and dry in an apple evaporator, or kiln constructed for the purpose. Where the roots are grown in quantity for the manufacturers of the "prepared" chicory, they are usually brought to the factory in the "green" state and there dried in kilns constructed for the purpose. P.kt., 5c.; 0z., 15c.; $\frac{1}{4}$ lb., 50c.

\section{COLLARDS}

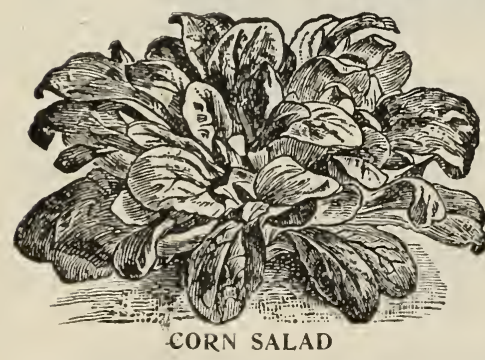

A variety of cabbage known in different sections as "Cole," "Colewort," or simply "Greens." It is extensively used in the south. where it continues in luxuriant growth all winter. Georgia, Southern or $\mathrm{Cre}=$ ole. We offer the true white or green stemmed sort so extensively used in the south, where it furnishes an abundance of food for man and

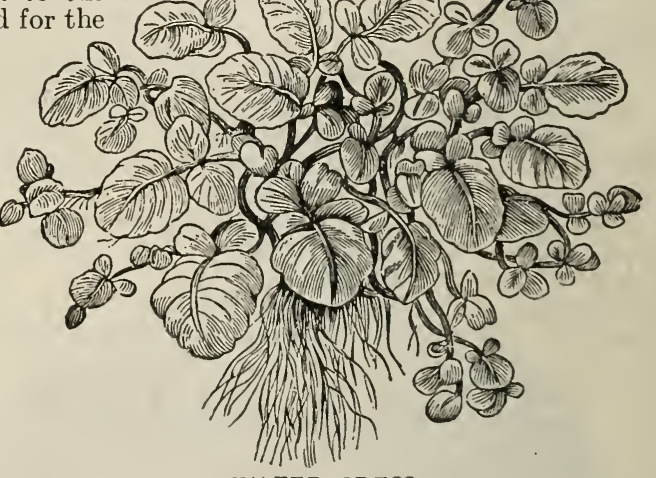

WATER CRESS

beast. Freezing does not injure, but rather improves their quality. Pkt., 5c.; oz., 10c.; 1b., \$1.00.

\section{CORN SALAD}

Fetticus, or Lamb's Lettuce. This small salad is used during the winter and spring months as a substitute for lettuce, and is also cooked and used like spinach. Pkt., 5c.; oz., 10c.; 2 oz., 15c.; $\frac{1}{4}$ lb., 20c.; lb., 60c.

Curled or Pepper Grass. This small salad is much used with lettuce, to the flavor of which its warm, pungent taste, makes a most agreeable addition. Pkt., 5c.; oz., 10c.; 2 oz., 15c.; 1 lb., 20c.; lb., 50c.

True Wăter. This is quite distinct from the last, and only thrives when its roots and stems are submerged in water. Pkt.,-5c.; oz., 30c.; 2 oz., 55c.; $\frac{1}{1}$ lb., \$1.00; lb., \$3.00. 


\section{CARROTS}

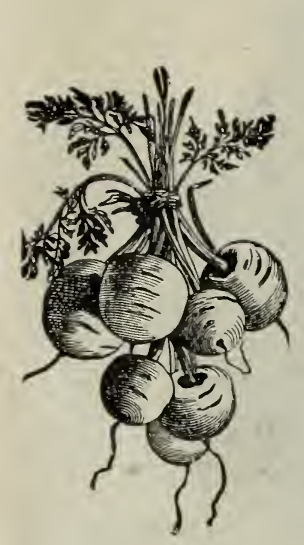

FRENCH FORCING

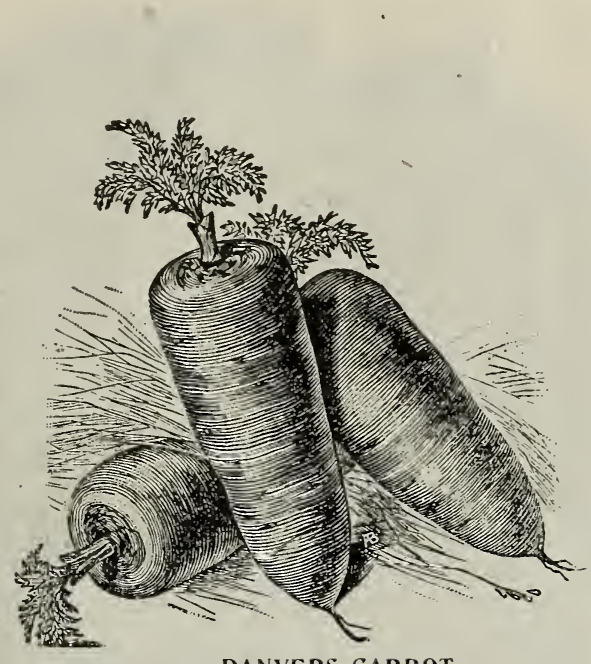

DANVERS CARROT

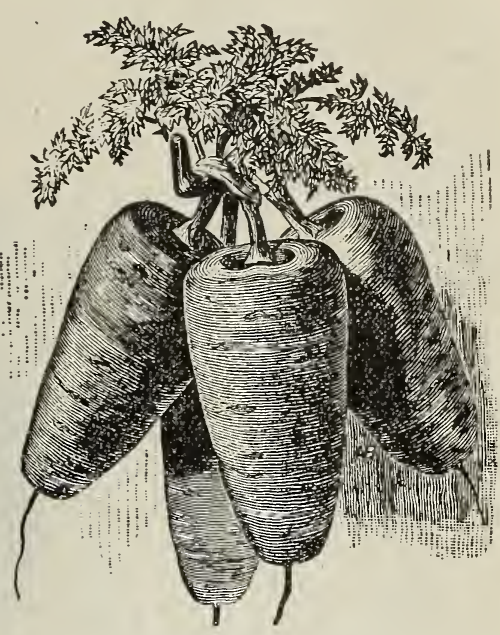

CHANTENAY CARROT

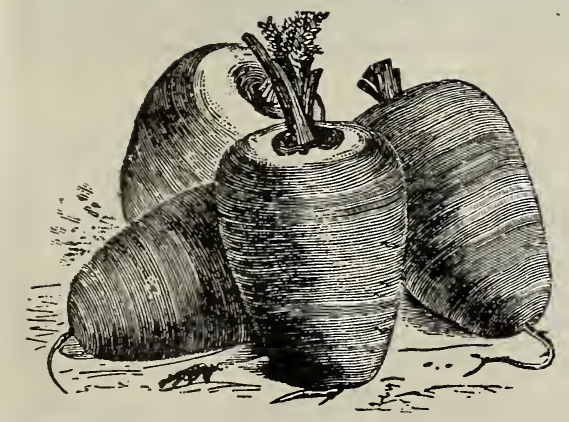

GUERANDE OR OX HEART CARROT

Early French Forcing. The earliest variety in cultivation and the best suited for forcing. Tops small, finely divided. The reddishorange colored roots are nearly round. When fully matured they are about 2 inches in diameter, but should be used before they are full grown and while young and tender.

Half Long Nantes. Tops of medium size; roots cylindrical, smooth, bright orange; flesh orange, becoming yellow in center, but with no distinct core. Of the finest quality and one of the most symmetrical and handsome of the medium sized sorts; excellent for the market or home garden.

Early Short Horn. Excellent for early planting out of doors. Tops small, coarsely divided; roots top-shaped, but tapering abruptly to a small tap; skin orange-red.

Guerande, or Ox Heart. Tops small for the size of the roots which are comparatively short but often reach a diameter of 5 inches, terminating abruptly in a small tap root. Flesh bright orange, fine grained and sweet. This variety is especially desirable for soil so hard and stiff that longer rooted sorts would not thrive in it. When young excellent for table use, and when mature equally good for stock.

Chantenay. Tops medium sized; necks small; roots tapering slightly but uniformly stump rooted and smooth; color deep orange-red; flesh very crisp and tender. Although this is a medium early sort, it furnishes roots of usable size as early as any, is a heavy cropper and is undoubtedly one of the best for both the market and private garden, while its great productiveness makes it very desirable as a field sort.

Danvers. Grown largely on account of its great productiveness and adaptability to all classes of soil. Tops of medium size, coarsely divided. The smooth and handsome roots are deep orange, of medium length, tapering uniformly to a blunt point; flesh sweet, crisp, tender and of a deep orange color. Although the roots of this variety are short, they produce as large a bulk as the longer field sorts and are more easily harvested.

James Intermediate. A variety intermediate between the Danvers and Long Orange. It tapers to a point not so blunt as the Danvers and is more symmetrical and not so long as the Long Orange.

Long Orange. The most popular of the older sorts for farm use on mellow soil. An improvement obtained by years of careful selection of the best formed and deepest colored roots.

St. Valery. A good late variety. It grows long, shape uniform, tapering from a wide shoulder to a point.

White Belgian. Grows one-third out of the ground. Root White, green above grourid with small top. Flesh rather coarse. The roots are of large size and the variety is extensively grown for stock feeding.

Improved Short White. We think this distinct variety is destined to take first rank as a field carrot, owing to its enormous productiveness and the ease with which it can be harvested.

\section{CARROT PRICES POSTPAID.}

If carrot is to go with other goods at the expense of the purchaser, 10 cents per pound may be deducted from these prices:

\begin{tabular}{lrrrr} 
& Pkt. & \multicolumn{1}{c}{ Oz. } & \multicolumn{1}{l}{ Lb. } & \multicolumn{1}{c}{ Lb. } \\
Early French Forcing $\ldots \ldots$ & $\$ 0.05$ & $\$ 0.10$ & $\$ 0.20$ & $\$ 0.75$ \\
Eariy Horn $\ldots \ldots \ldots \ldots \ldots \ldots$ & .05 & .10 & .20 & .75 \\
Half Long Nantes. $\ldots \ldots \ldots$ & .05 & .10 & .20 & .70 \\
Chantenay. $\ldots \ldots \ldots \ldots \ldots$ & .05 & .10 & .20 & .70 \\
Ge urande or Ox Heart. ... & .05 & .10 & .20 & .70
\end{tabular}

\begin{tabular}{|c|c|c|c|c|}
\hline & Pkt. & $\mathrm{Oz}$. & $\frac{1}{4} \mathrm{Lb}$. & Lb. \\
\hline Intermediate & $\begin{array}{r}\$ 0.05 \\
05\end{array}$ & $\$ 0.10$ & $\begin{array}{l}0.25 \\
.20\end{array}$ & $\begin{array}{r}1.00 \\
.60\end{array}$ \\
\hline Saint Valery....... & .05 & .10 & .20 & .65 \\
\hline Long Orange & .05 & .10 & .20 & .60 \\
\hline White Belgian & & .05 & .15 & .50 \\
\hline mproved Short White & .05 & .10 & .15 & .50 \\
\hline
\end{tabular}


Extra Early Express. An extra early sort, in which the plants are compact, with round, thick leaves, that form an ovial head, which is astonishingly large for the size of the plants.

Early Jersey Wakefield Cabbage. Our selected stock. 'This is one of the most important varieties in the list. Great care must be excreised in the growing of the seed to have it pure and true to type. We give especial attention to the growing of our Wakefield stock, and its uniform excellence is a source of gratification to us.

Large or Charleston Wakefield. This is a selection from the best extra early Jersey Wakefield, which will average about 50 per cent larger.

E a r l y York. Heads small, heart-shaped, firm and tender. Can be planted 15 to 18 inches apart.

Early Winnigstadt. 'The heads are of the same size as the Jersey Wakefield, but more sharply pointed in form and not so early.

Early Spring. Its great value lies in its being a first early flat cabbage, a type much preferred over pointed heads by many people. It has a short stem and only four to five outside leaves, and these so small that it may be planted 21 inches apart.

Ear!y Summer. This is a very valuable variety, not only for the market gardener, but also the private grower, as its heading season is between the Jersey Wakefield and early Drumhead.

Succession. This variety which originated on Long Island, we regard as valuable an acquisition as the famous Early Summer.

Vandergaw. One of the best sorts for the market gàrdener, as it forms large, solid heads much larger than the

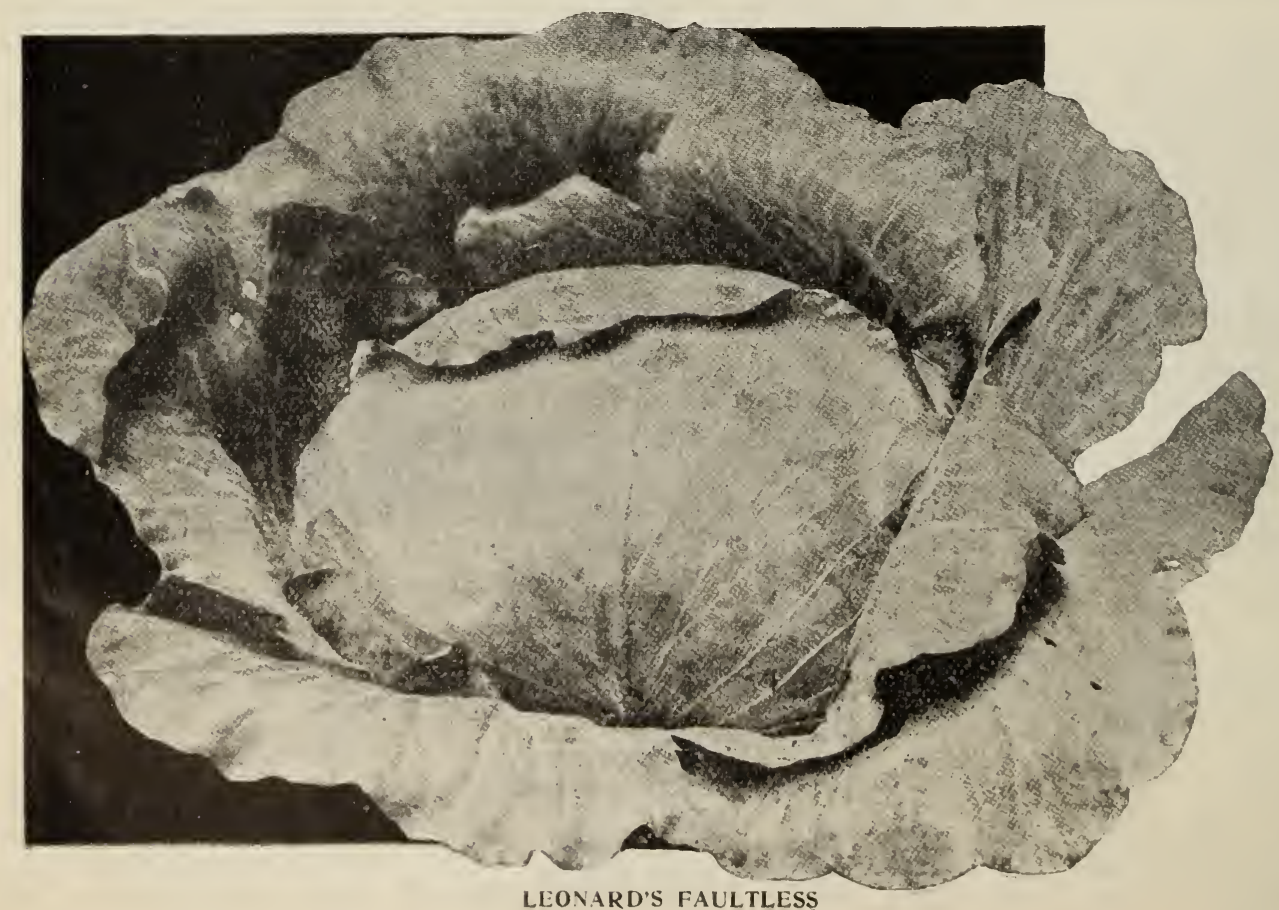
Early Summer and almost as early.

All Seasons. Ready to market nearly as early as Early summer, while considerably larger in size.

Early All= head. For uniformity, reliability of heading, s i z e, earliness and quality, it has few equals.

L e o n a rd's Faultless $C a b=$ bage. Is now and for fifteen years has been the favorite second Early Cabbage at Chicago.

The product of this seed outsells any other second early cabbage two to one on the hom e market. It can be marketed in the early sum- 


\section{CABBAGE (Continued)}

mer; during midsummer, in the fall and early winter, making it the best all purpose variety ever introduced. It is popular alike with the grocer, kraut maker and shipper. It is possessed of earliness, large size, compactness and will produce more salable heads to the acre than any other stock we know of. It is of the succession type, but is earlier, head is rounder, sits out of the under leaves higher, has a darker color of leaf and can be planted closer. Pkt., 10c.; 0z., 25c.; $\frac{1}{4}$ lb., 75c.

There is no substitute for this Cabbage, the Strain is Distinct and can be had from one source only. Pound, \$3.00.

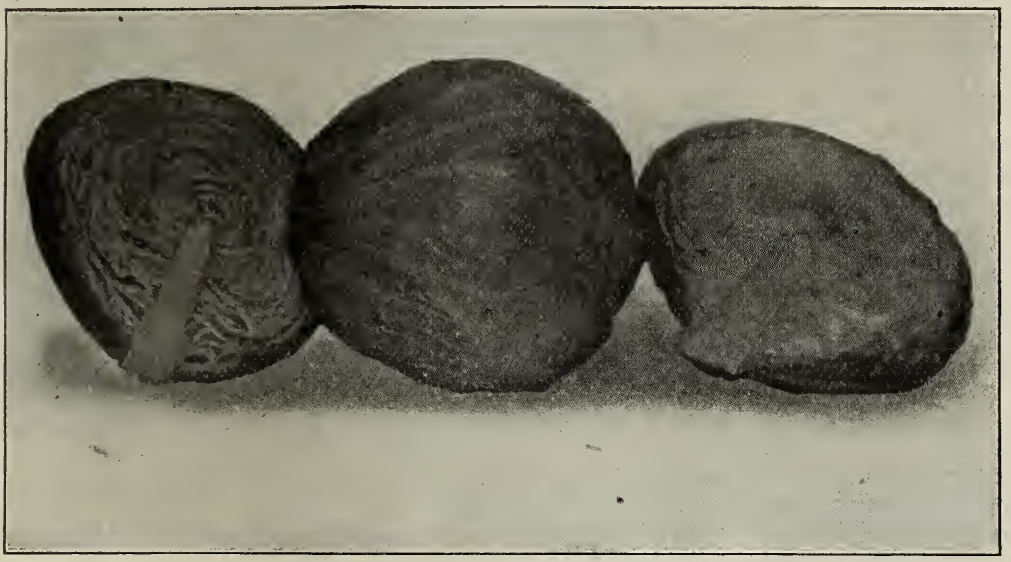

THE HOLLAND CABBAGE-LEONARD'S STRAIN

The Holland Cabbage, Leonard's Strain. The Heaviest Cabbage for the size of head ever introduced.

This cabbage in many localities is the most popular for winter and early spring marketing. It is heavy and remains solid longer than any other long keeping cabbage. For winter shipping it is unsurpassed. The main question for the grower to solve is where to get the genuine seed, for the popularity and paying qualities of the cabbage itself, when it is right, are points long ago decided.

Seed of the true Holland Cabbage is not plentiful; it is produced on a limited area at one or two points only. Seed grown anywhere else deteriorates, fails to show up the proper characteristics and is but a very unsatisfactory substitute. Since 1896 we have succeeded in securing the seed crops of a grower of this cabbage which for uniformity have met the requirements of the large cabbage growers of Chicago, Racine and other Holland cabbage shipping points, and which have made for us a reputation for handling the best strain of this important article. We introduced the seed as Leonard's Strain and our sales are only limited by the quantity of seed our grower can produce. We do not' hesitate to sav that Leonard's strain of Holland cabbage is the purest to be had. Pkt., $10 \mathrm{c} ; 0 \mathrm{z} ., 35 \mathrm{c} ; \mathrm{I=4} \mathrm{lb}$., $\$ 1.00$; per Pound, $\$ 4.00$.

The Holland Cabbage (Short Stem Strain). This strain of Holland Cabbage differs from the original Leonard Strain in the height of the stem only. In all other respects it is the same. It has been bred up to meet the requirements of the grower who works heavy, rich land. The long stem of the original strain in extra heavy soil has been thought to be something of a fault and the growers have been calling for a stock that would retain all the good points of the original with the additional advantage of dwarfer habit. We confidentially recommend this strain as being an ideal stock to all growers who deem their soil over-rich for the original long stem strain. We also recommend it for trial to all growers of Holland Cabbage. Pkt., 10c; oz., 35c; $\frac{1}{4}$ lb., \$1.00; per lb., \$4.00.

Glory of Enkhuizen. This is an excellent midsummer variety. It comes in about a week earlier than All Seasons, makes a nice large head, has few outer leaves and can be planted close. Our tests show it to be worthy of a place among the new varieties of merit and we can recommend it as a good addition to the list. Pkt., 10c.; 0z., 25c.; $\frac{1}{4}$ lb., 75 c.; per lb., $\$ 2.50$.

The Lupton. The Lupton Cabbage is the result of an effort to combine in one variety the best qualities of the second-early and the late sorts. It is a little earlier than any one of the various strains of Flat Dutch and Drumhead.

Early Flat Dut ch. This variety is equally as popular as the Early Drumhead.

Early Drumhead. This popular variety follows the Early Summer in heading and is one of the

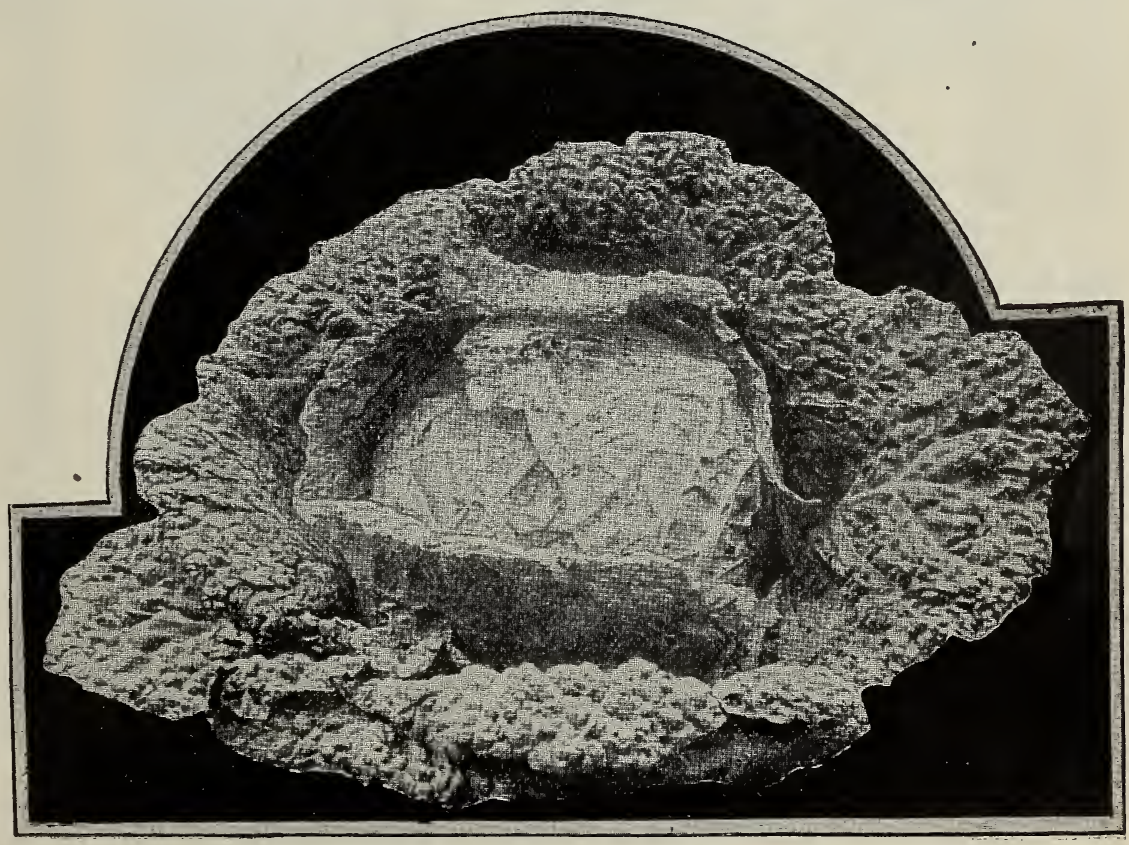

IMPROVED AMERICAN SAVOY (See page 28) 


\section{CABBAGE (Continued)}

most valuable varieties. It is ready for marketing two or three weeks earlier than the Late Drumhead.

Blue Strain Fottler's Brunswick. Of dwarf compact growth, the solid flat heads rest on the soil, while the few outer leaves grow closely about the heads.

Improved American Savoy. The best of all the Savoys for general market or home use.

Louisville Drumhead. 'This fine cabbage is very popular' with the kraut makers. It is a medium late variety, forming a large solid head, which seldom bursts.

Mammoth Rock Red. The largest heading of any red sort. Heads are hard, of deep-red color, quality excellent. keeper.

Red Drumhead. The standard pickling variety. A good

Leonard's Luxemburg. This cabbage will retain its fine green color until late in the spring, and is often sold for new cabbage after being covered all winter. Fine looking, of good size and excellent quality.

Leonard's Improved Bridgeport Drumhead. 'This is a stan!ard winter variety on the Chicago markets, and is used largely for shipping south.

Sure Head. A fine variety for main crop. A good shipper and sure header.

Stonemason Drumhead. A late large heading variety; but not as fine grained as others.

Marblehead Mammoth. A large late variety of fairly good quality.

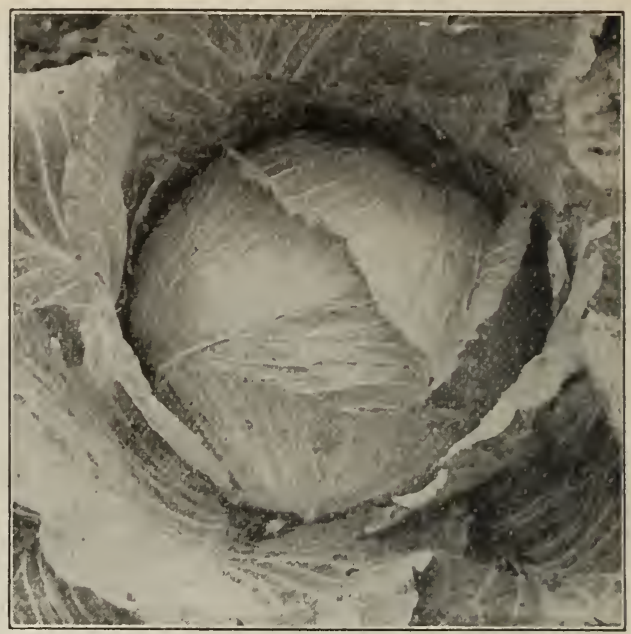

DANISH BALLHEAD

Large Late Drumhead. A late variety of large size.

Premium Flat Dutch. This variety of late cabbage is a standard in all sections for winter use. Our selected stock is unsurpassed.

Danish Ballhead Cabbage. For a winter cabbage for early spring sales some of our local gardeners consider this variety excellent. Described as follows: It has been selected and perfected for miore than fifty years by the Danish gardeners, who prize it so highly that they grow it almost exclusively for winter cabbage, and annually export large quantities of it. It is hard heading, and long keeping cabbage. Heads round as a ball, solid, fine grained, has few outer leaves, tender, crisp and of unexcelled flavor.

CABBAGE PRICE LIST.

The Packet, Ounce and Pound Prices Are for the Seed Prepaid by Mail or Express. Customers Purchasing Pounds or Larger Quantities to Go with Other Goods, Deduct 10 Cents per Lb.

Early Etampes Pkt. $0 z$

Early Express $\$ 0.05$

$\mathrm{Oz}$.

$.05 \quad .25$

Farly Jersey Wakefield.

Charleston Wakefield

.05

.05

Early Wennigstadt.

Early York

.05

Early Spring

Early Summer.

Succession. .

Vandergaw.

All Seasons

Early Allhead

The Lupton.

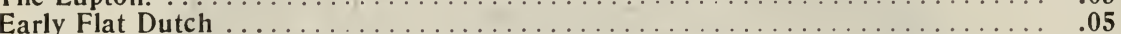

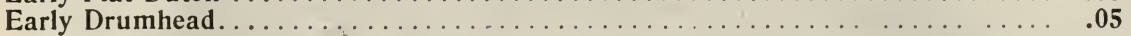

Blue Strain Fottler. . . . . . . . . .

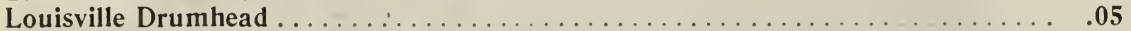

Leonard's Luxemburg

Leonard's Improved Bridgeport

Surehead ...................................... 05

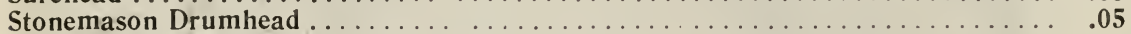

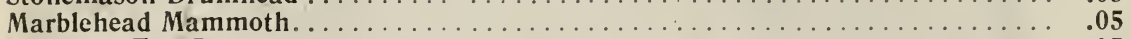

Premium Flat Dutch $\ldots \ldots \ldots \ldots \ldots \ldots \ldots \ldots \ldots \ldots \ldots \ldots \ldots \ldots \ldots \ldots \ldots \ldots . .05$

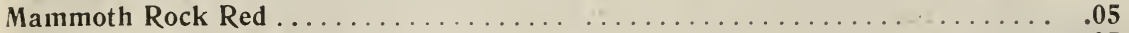

Red Drumhead. ...................... 05

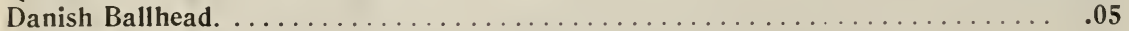

Improved American Savoy. .

Large Late Drumhead.

$\frac{1}{4}$ Lb. Lb.

$\$ 0.60$

$\begin{array}{ll}.60 & 2.00\end{array}$

.75

$.75 \quad 2.50$

$.50 \quad 1.75$

$.50 \quad 1.50$

$.75 \quad 3.00$

$.60 \quad 2.00$

$\begin{array}{ll}.75 & 2.50 \\ .60\end{array}$

$.60 \quad 2.00$

$\begin{array}{ll}.75 & 2.50\end{array}$

$\begin{array}{ll}75 & 2.50\end{array}$

$.60 \quad 2.00$

$.60 \quad 2.00$

$.60 \quad 2.00$

$\begin{array}{ll}.50 & 2.00\end{array}$

$.40 \quad 1.50$

$\begin{array}{ll}.75 & 3.00\end{array}$

$.75 \quad 3.00$

$.60 \quad 2.00$

$.60 \quad 2.00$

$.60 \quad 2.00$

$.60 \quad 2.00$

$.60 \quad 2.00$

$.60 \quad 2.00$

$1.00 \quad 3.50$

$.60-2.00$

$.60 \quad 2.00$

Leonard's Vegetable Seeds are the Market Gardeners' standard.

Market gardeners do not knowingly take risks in buying their seed. They cannot afford to. It is certain, therefore, that their patronage is given only to those seedsmen whom they consider entirely reliable. The best proof that a seedsman is worthy of confidence is shown by the extent of his local market-garden trade, and it is well known that we have the largest trade in this line of any house in the West.

We test our seeds on our own farms where we maintain large trial grounds.

Our position as Market Gardeners' Seedsmen is well and favorably known both at homeand throughout the country. Our standing in this branch of the seed business has been long established. The Market Gardener or Amateur Planter, when he uses Leonard's Seeds, may therefore feel reasonably sure that he is planting the best seed obtainable. 


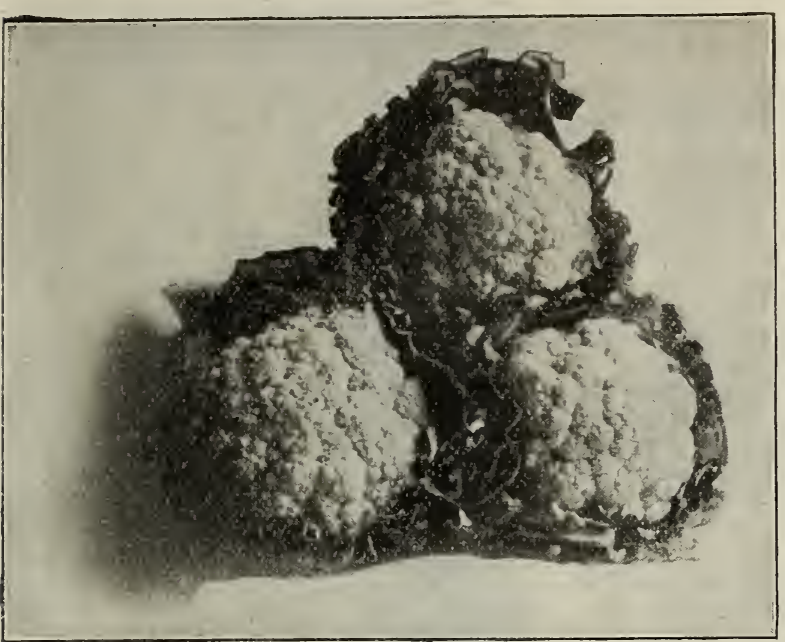

LEONARD'S SNOWBALL CAULIFLOWER.

\section{CAULIFLOWER}

The Cauliflower delights in a rich soil and an abundance of water. Sow seed for an early summer crop in Feburary or March, in a hotbed, and when plants are three or four inches high transplant four inches apart in boxes or frames. In the middle of spring, or as soon as the gardener deems it prudent, the plants can be removed to the open ground. Set plants from two to two and a half feet apart each way. For late Cauliflower sow seed in a cool, moist place, in this latitude, about the end of May.

Our position as MARKET GARDEN= ERS' SEEDMEN is well and favorably known both at home and throughout the country. Our pre=eminent standing in this line of the Seed Business has been long established. The Market Gardener, when he plants LEONARD'S SEEDS, may therefore feel reasonably sure that he is planting the best seed obtainable.

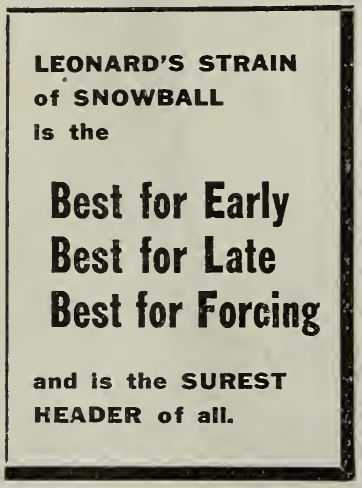

Leonard's Snowball. The leading Cauliflower at Chicago, and unquestionably the purest strain of "Snowball" Cauliflower seed to be had. Heads uniform; of desirable market size and of snowy whiteness.

After many years' competitive tests it is pronounced by expert cauliflower growers to be the best for both early and late planting. Successful frame growers of cauliflower say that under glass culture our Snowball outclasses any strain of cauliflower seed known to them. There are some expert cauliflower growers at Chicago, none better anywhere that we are aware of, other strains of snowball seed are well known to them and this strain of ours is their favorite for early, for late and for forcing. Strong recommendations surely. Pkt., 15c.; oz., $\$ 2.00 ; \frac{1}{4} 1 \mathrm{lb}$., $\$ 8.00 ; 1 \mathrm{lb}$., $\$ 32.00$.

Danish Dry Weather. We take pleasure in introducing this Cauliflower to our customers. It is from one of the best growers in Denmark and we recommend it highly to market gardeners for a trial. It is claimed to be a splendid strain for a dry season and equally good in all weathers-From the reports we have regarding this stock from gardeners who tried it last year and year before, we consider it a valuable addition to the list and a worthy companion to Our Famous Snowball.

Leonard's Earliest Erfurt. A variety that has given excellent satisfaction to our home gardeners. It is snow white and a sure header. Gardeners will be amply repaid by giving this variety a fair trial. $\mathbf{O z . ,} \$ \mathbf{\$ 2 . 0 0 ;} ; \frac{1}{4} \mathbf{l b}$., $\$ 8.00$.

Extra Early Paris. This is a good early sort, and in a good season does well. Not as sure a header as the higher priced varieties. Oz., 50c.; $\frac{1}{4}$ lb., $\$ 2.00$.

Autumn Giant. A late sort of fairly good quality. Will do well under favorable conditions. Oz., 50c.; $\frac{1}{4} \mathbf{l b} ., \$ 1.75$.

Le Normand's Short Stem. Considered by the French one of the very best sorts. Plant hardy, compact growing, and producing many leaves which protect the close, solid curd, keeping it well blanched. Pkt., 5c.; oz., 75c.; 2 oz., $\$ 1.25 ; \frac{1}{4} \mathrm{lb} ., \$ 2.25$.

Large Algiers. A valuable late sort, of the best quality, and very popular everywhere. Plant large, but of upright growth, the leaves protecting the heads so that they will endure uninjured a frost that would ruin other sorts. Pkt., 5c.; 0z., 80c.; 2 oz., \$1.50; $\frac{1}{4}$ lb., $\$ 2.75$. 


\section{SWEET CORN.}

Mammoth White Cory. 'The ears are twelve rowed, much larger than the old Cory, white cobbed, and covered with very large white grains of good quality.

Early Cory Red Cob. This variety is the favorite for first early, and no other variety has proved earlier.

White Cob Cory. 'This is an improvement over the Farly Cory, as the cob is white, which gives it a finer appearance. It is as early as the Early Cory and of excellent quality.

Chicago Market or Ballard. 'This is the largest and best early corn in existence, twelve rowed, white cobbed and of exceedingly fine quality.

Premo. 'The illustration herewith is from a photograph. It is a "sixty-day" sweet corn. It not only combines all the merits of the leading early varieties, but it is also really superior to them all in size, quality and yield. Premo can be planted fully as early as the Adams, for the young plants withstand slight frosts, while other varieties are tender and the seed of them will rot if planted before the soil becomes warm. The stalks grow about 5 feet high and are very vigorous, generally bearing two well-developed ears to a stalk.

Extra Early Adams. 'This is an extra early field variety, but is much used as an early market variety, being sweet and juicy.

Early Minnesota. One of the standard early sorts. Ready for market two weeks later than Cory or Chicago market.

Perry's Hybrid. An early variety of splendid quality. Kernels tinged with pink when ripe, with white cob.

New Champion. This corn is unsurpassed for market use, owing to its large size and fine appearance. It is medium early, coming in at the same time as Perry's Hybrid. It is fourteen rowed and a splendid cropper.

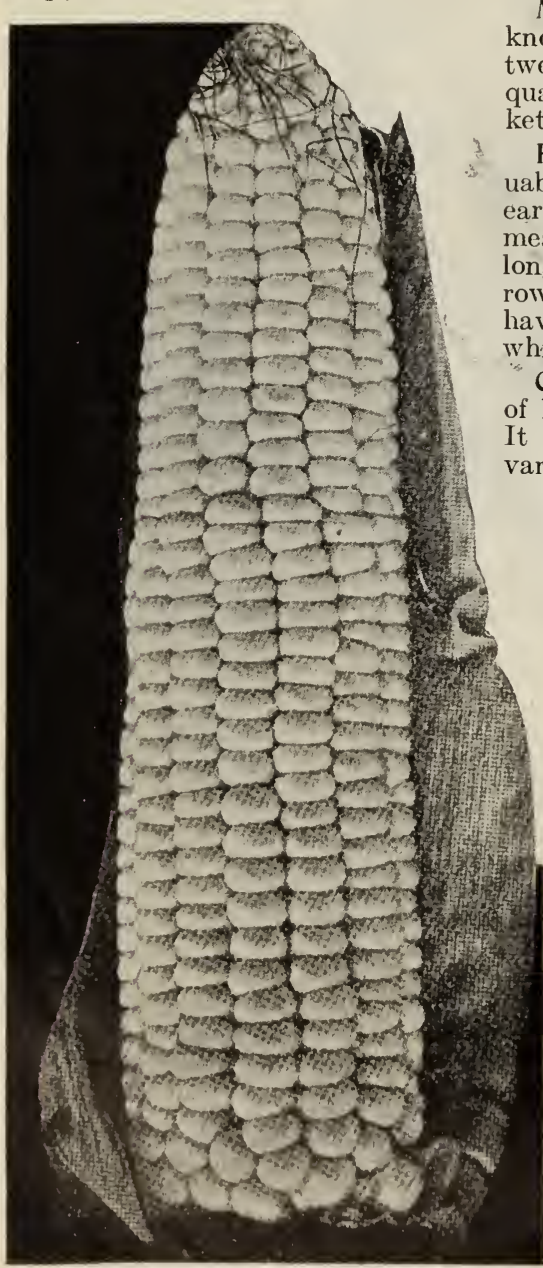

KENDALL'S EARLY GIANT
Moore's Early Concord. A well known early variety of large size, twelve rowed and of excellent quality.' This makes a fine market corn.

Kendall's Early Giant. A valuable new early sweet corn. The ears grow to a tremendous size, measuring eight to ten inches long, and having ten to eighteen rows on each cob, the majority having twelve rows; kernels pure white; sweet, tender.

Crosby's Early. An early corn of large size and choice quality. It has long been a standard variety.

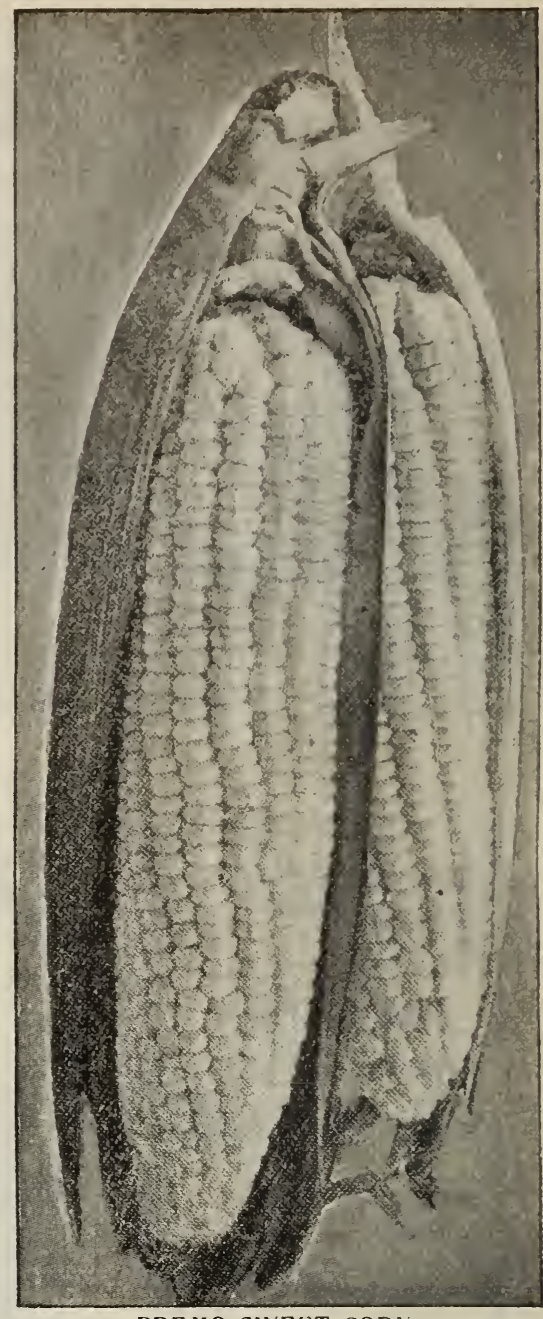

PREMO SWEET CORN

\section{SWEET CORN PRICE LIST.}

We send all packets, pints and quarts free by express or mail at catalogue prices. Purchaser pays the freight on half pecks, pecks and bushels.

\section{Premo}

Mammoth White Cory

Early Cory Red Cob

Early Champion.

Perry's Hybrid

Metropolitan.

Adams' Early

Early Minnesota.

Chicago Market

Early Crosby

Early Evergreen

Moore's Early Concord

Old Colony

Country Gentleman.........

Black Mexican

Hickox.

Late Mammoth

Zig Zag Evergreen.

Stowell's Evergreen

Kendall's Early Giant

Egyptian

Mammoth Sugar
Pkt. Pt. Qt. $\frac{1}{2}$ Pk. Pk. Bu.

$\$ 0.10 \$ 0.20 \$ 0.35 \$ 0.60 \$ 1.00 \$ 4.00$

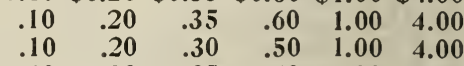

$\begin{array}{llllll}.10 & .20 & .35 & .60 & 1.00 & 4.00\end{array}$

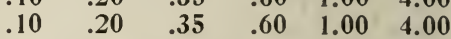

$\begin{array}{llllll}.10 & .20 & .35 & .60 & 1.00 & 4.00\end{array}$

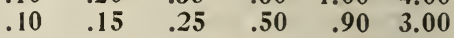

$60-1.00 \quad 4.00$

$\begin{array}{llllll}.10 & .30 & .35 & .60 & 1.00 & 4.00 \\ .10 & .20 & .35 & .60 & 1.00 & 4.00\end{array}$

$\begin{array}{llllll}.10 & .20 & .35 & .60 & 1.00 & 4.00\end{array}$

$\begin{array}{llllll}.10 & .20 & .35 & .60 & 1.00 & 4.00\end{array}$

$\begin{array}{llllll}.10 & .20 & .30 & .50 & 1.00 & 4.00\end{array}$

$\begin{array}{llllll}.10 & .20 & .35 & .60 & 1.00 & 3.50\end{array}$

$\begin{array}{llllll}.10 & .20 & .35 & .60 & 1.00 & 3.50 \\ .10 & .20 & .35 & .60 & 1.00 & 4.00\end{array}$

$.60-1.00-4.00$

$\begin{array}{llllll}.10 & .20 & .35 & .60 & \cdot 1.00 & 4.00\end{array}$

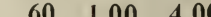

$\begin{array}{llllll}.10 & .20 & .35 & .60 & 1.00 & 4.00\end{array}$

$\begin{array}{llllll}.10 & .20 & .35 & .60 & 1.00 & 4.00\end{array}$

$\begin{array}{llllll}.10 & .20 & .35 & .60 & 1.00 & 4.00\end{array}$

$\begin{array}{llllll}.10 & .20 & .35 & .60 & 1.00 & 4.00\end{array}$

$\begin{array}{llllll}.10 & .20 & .35 & .60 & 1.00 & 4.00\end{array}$ 


\section{SWEET CORN.}

Hickox Hybrid. Earlier than Stowell's Evergreen, and makes a large, attractive ear of very white and handsome grain. It is one of the best varieties for canners' use. By planting it at the same time as Stowell's Evergreen the season will be lengthened considerably, as the Hickox will be about through by the time Stowell's Evergreen comes in; very prolific, ordinarily every stalk will have two large, fully developed ears. The best sort for drying.

Early Evergreen. The ears of this new corn grows 8 inches long, are mostly 14 to 18 rows. This is a magnificent kind for market gardeners and for main crop in every home garden. It ripens 10 to 12 days in advance of Stowell's Evergreen and is equally as good for all purposes. The kernels are very sweet and tender, and when eaten from the cob break off free from husky tips so common to some otherwise fine table corns.

Metropolitan. A new early sort, only a few days later than Cory. The ears are about 9 inches in length, 10 to 12 rowed, well filled to the tip with large, deep kernels, which are very sweet and tender. It is an excellent variety for market gardeners.

Zigzag Evergreen. This fine new strain possesses the distinct characteristics which have made Stowell's Evergreen so deservedly the favorite for main crop, but produces ears fit to use from one week to ten days earlier

old Colony. This variety is two weeks earlier than the Evergreen, and almost as large. It is considered the best and sweetest by canning factories. A fine paying variety for market.

Country Gentleman. We have a stock of this excellent sweet corn that is exceptionally true to type. There is no sweet corn that compares with the Country Gentleman for sweetness. It is the variety par excellence where quality is desired. Market gardeners who make a specialty of growing for hotels and high class restaurant trade use this as a main crop variety in preference to any other. For home use it will be found superior and it is very productive. The fact that it is a favorite variety with canners proves its merit.

Egyptian or Washington Market. A standard variety, in season between Evergreen and Mammoth Sugar. Very sweet and well adapted for canning.

Mammoth Sugar. A large late variety having ears of mammoth size, 14 to 20 rows. Quality excellent, not exceeded by any variety. A good canners' variety, being white grained and very uniform. A week later than Stowell's Evergreen.

Black Mexican. 'This corn, when in condition for the table, cooks remarkably white; but the ripe grain is black or bluish-black. It is

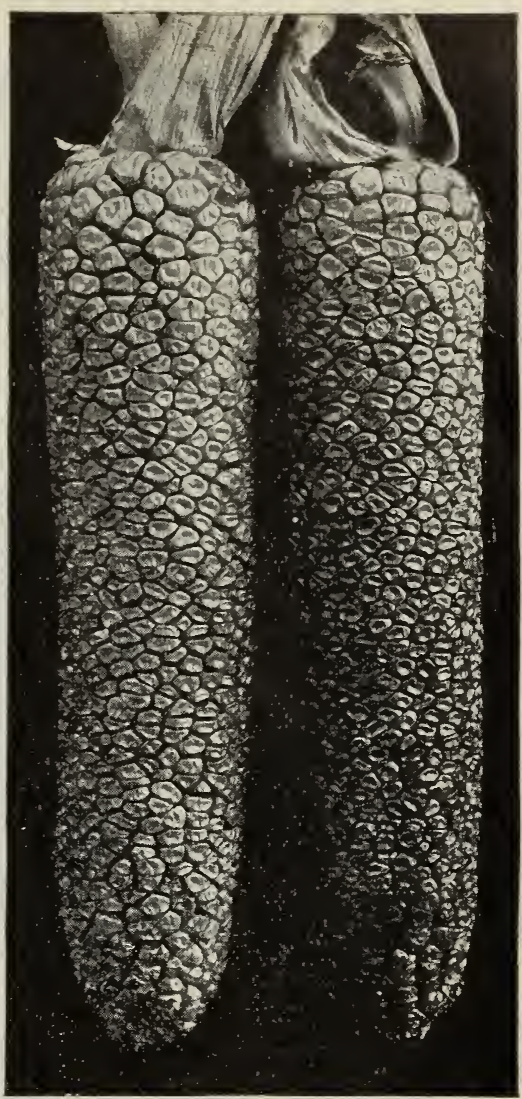

COUNTRY GENTLEMAN surpassed by none in tenderness. For family use it is considered by many the most desirable of the medium late sorts. It does especially well for second early in the south.

Stowell's Evergreen. This standard main crop variety excels all other late sorts in sweetness and productiveness. It is more popular than any other for canning, for marketing and for the home garden. Great care has to be exercised in the selection of stock to grow seed from, as this variety has a tendency to deterioration and a shorter grain, which makes it less sugary and desirable. We have a large and growing trade among canners and market gardeners who must have a genuine Stowell's Evergreen, and our stock is known as the safest seed for all purposes.

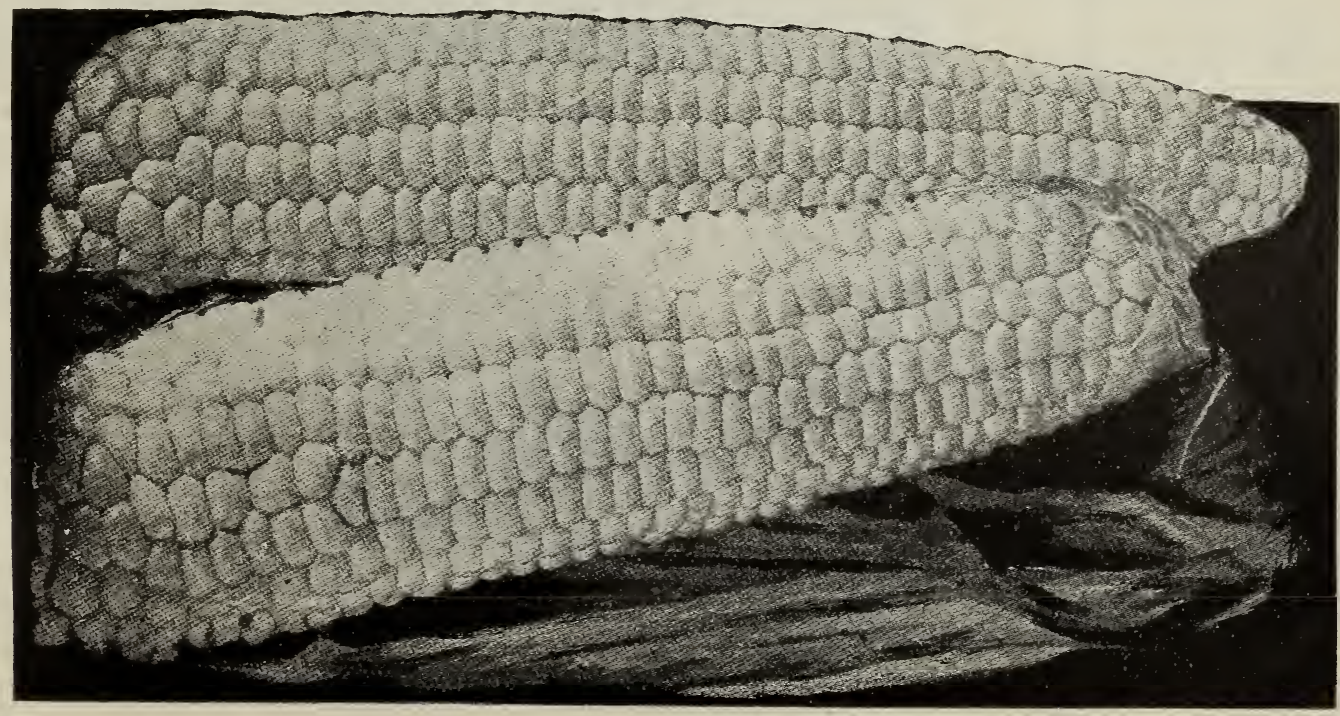




\section{CELERY}

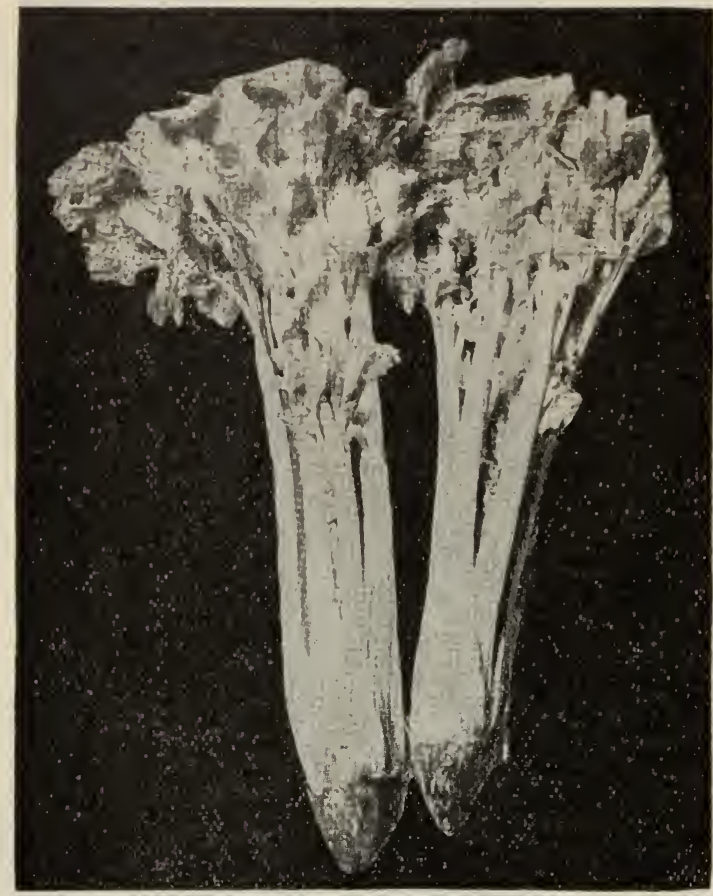

GOLDEN SELF BLANCHING.

and of fai : quality.

Crawford's Half Dwarf. When blanched is of rather yellowishwhite color, and is quite solid and well flavored.

Evan's Triumph. One of the best late sorts. This variety has a very strong and vigorous plant with large, very white, crisp, brittle, tender and fine flavored stalks. It is late and requires the whole season to develop, but will keep well for a very long time.

Boston Market. For many years one of the most popular sorts in the markets of Boston. Instead of a single large heart it forms a number of smaller ones, which are very white, and remarkably tender and crisp. The best variety for light soils.

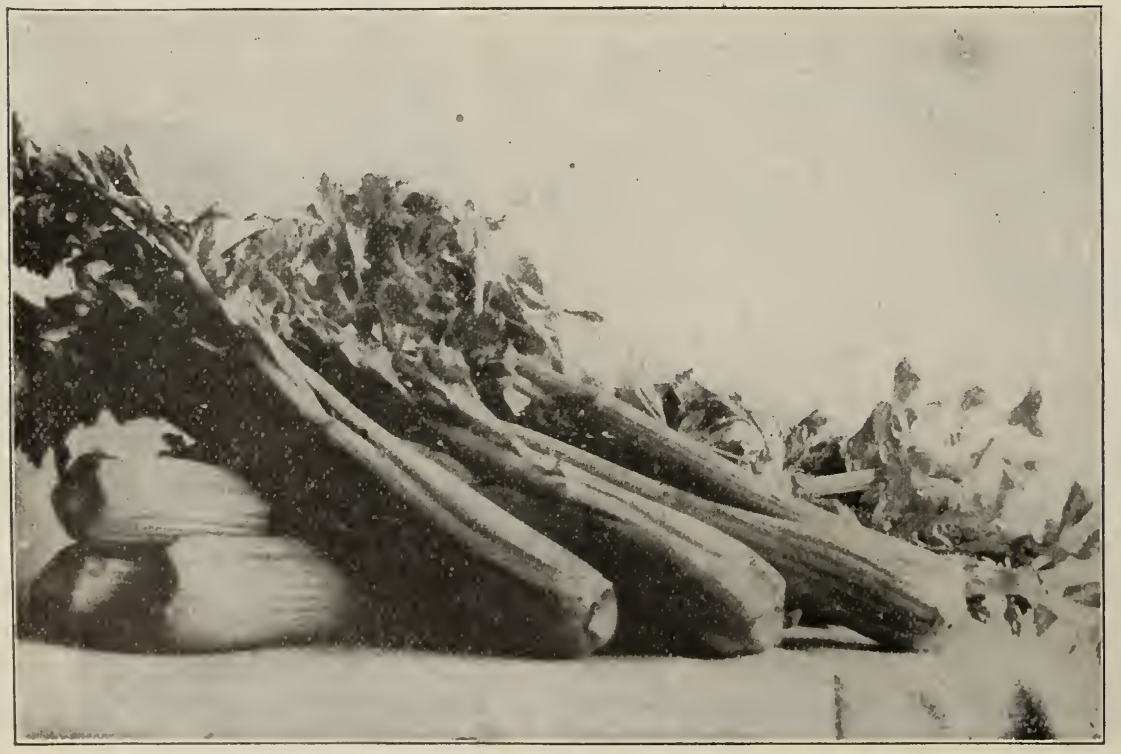

EVANS' TRIUMPH.

Winter Queen Celery. This is, without doubt, the most valuable variety of celery for winter and spring use ever introduced, even excelling the celebrated Perfection Heartwell as a late winter keeper. It is also much stouter, thicker and heavier, with double the amount of heart of any known celery.

Giant Pascal. This is a green leaved variety dereloped from the Golden Yellow Self-Blanching, and is an excellent sort for fall and winter use. It blanches to a beautiful yellowish-white color, is very solid and crisp and of $a^{\circ}$ fine nutty flavor.

Seymour's White Solid. A large sized, vigorous growing variety; stalks white, round, very crisp; perfectly solid and of superior flavor. 


\section{CELERY - Continued}

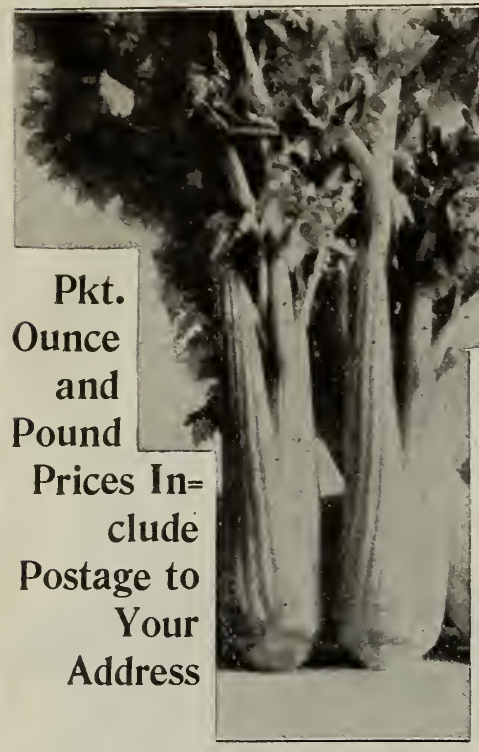

GIANT GOLDEN HEART

Giant Golden Heart. This variety attains a large size, but still remains crisp and tender. It is a fine keeper and is a favorite on the Chicago market.

Soup or Cutting Celery. This variety is adapted to sowing thick in rows and cutting when three or four inches high, to use for soup flavoring.

\section{GERMAN CELERY OR CELERIAC.}

Large Smooth Prague. Has a large smooth root, and is the finest of all celeriac.

Apple Shaped. Not as smooth as the above, but of good form.

Turnip Rooted. This is the ordinary and well-known variety CELERY PRICES.

\begin{tabular}{|c|c|c|c|c|}
\hline Golden Self=Blanching & $\begin{array}{l}\text { Pkt. } \\
\$ 0.10\end{array}$ & $\begin{array}{c}\text { Oz. } \\
\$ 0.50\end{array}$ & $\frac{1}{4} \mathrm{lb}$. & Lb. \\
\hline White Plume........... & .05 & .20 & $\$ 0.60$ & $\$ 2.00$ \\
\hline Giant Golden Heart. & .05 & .15 & .50 & 1.50 \\
\hline Dwarf Golden Heart ............ & .05 & .15 & .50 & 1.50 \\
\hline Dwarf White Kalamazoo. . . . . . . & .05 & .15 & .40 & 1.35 \\
\hline Crawford's Half Dwarf. . . . . . . & .05 & .15 & .40 & 1.35 \\
\hline Perfection Heartwell. . . & .05 & .15 & .40 & 1.25 \\
\hline Seymour White Solid. & .05 & .15 & .40 & 1.25 \\
\hline Evans' Triumph $\ldots \ldots \ldots \ldots \ldots$ & .05 & .15 & .40 & 1.25 \\
\hline Giant Pascal. & .05 & .15 & .40 & 1.25 \\
\hline Soup or Cutting. & .05 & .10 & .30 & 1.00 \\
\hline Smooth Prague Celeriac. . . . . . . . & .05 & .15 & .50 & 1.50 \\
\hline Apple Shaped Celeriac ......... & .05 & .15 & .40 & 1.25 \\
\hline Turnip Rooted Celeriac $\ldots \ldots \ldots$ & .05 & .15 & .40 & 1.25 \\
\hline
\end{tabular}

\section{CUCUMBER}

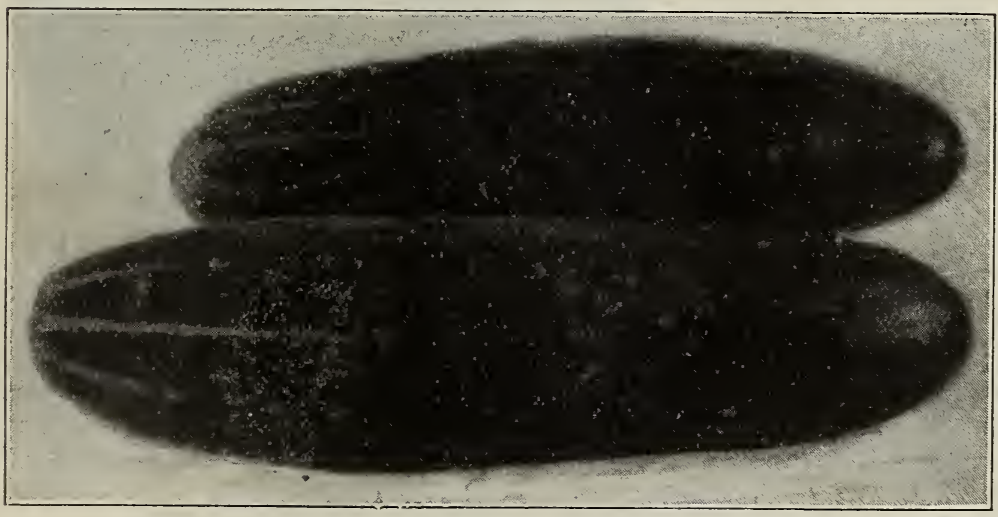

This is one of the vegetables that can be grown to perfection by any one who can control a few square yards of soil that is fully exposed to the sun. Every family should be supplied from its own garden, since the fruit is so much better when gathered fresh from the vines that it is in the more or less wilted condition in which it is found on the market.

Pick the fruit before it begins to ripen, as the vines will cease setting fruit as soon as any seed begins to mature.

\section{Cucumber Price List Page 34}

LEONARD'S GRENHOUSE

Leonard's Greenhouse. This is a stock of cucumber upon which we have spent much time. The seed we offer is of our own growing and the selection is from the finest types only. The value of it to market gardeners and greenhouse men who desire a uniform, deep green, extra long cucumber, will be appreciated as soon as tried. For many years we have been aiming to perfect this stock and át last our efforts have been rewårded. Nothing more choice in the way of a greenhouse cucumber has ever been sent out.

This cucumber has been well tried by expert green= house growers. In every case they report great satisfaction with it

Our friends who grow their cucumbers outside will find this stock superior in all respects for this purpose also. It requires no extra culture, forms a slicer of exceeding firmness, is an early bearer and very productive.

Evergreen White Spine. Beautiful in shape and color, and of the finest quality. The fruit is long, cylindrical, dark green, with very white, crisp and tender flesh. An entirely new and distinct sort de- veloped through very careful selection, our aim being to secure the best possible table cucumber. The vine is vigorous and productive, and comes into full bearing early. An excellent sort for culture under glass.

Fordhook Famous. Of the true White Spine type. Vines produce an enormous crop, being of unusually vigorous growth. Perfectly smooth and very dark green, the handsome fruits measure 12 to 18 inches long; they are always straight-never turn yellow, and are extra solid. The beautiful white flesh is firm, crisp, and of most delicious flavor. The flesh seems to be all there is of the cucumber, as the seed space is extremely small.

Davis Perfect. This very desirable new sort, originated with one of the largest market gardeners near Grand Rapids, Mich. In color, a dark, glossy green; shape, slim and symmetrical, with an average length of ten to twelve inches. They hold their color until nearly ripe when they turn white. It is as early as the earliest strain of White Spine and it out-yields this standard sort. 


\section{CUCUMBERS-Continued}

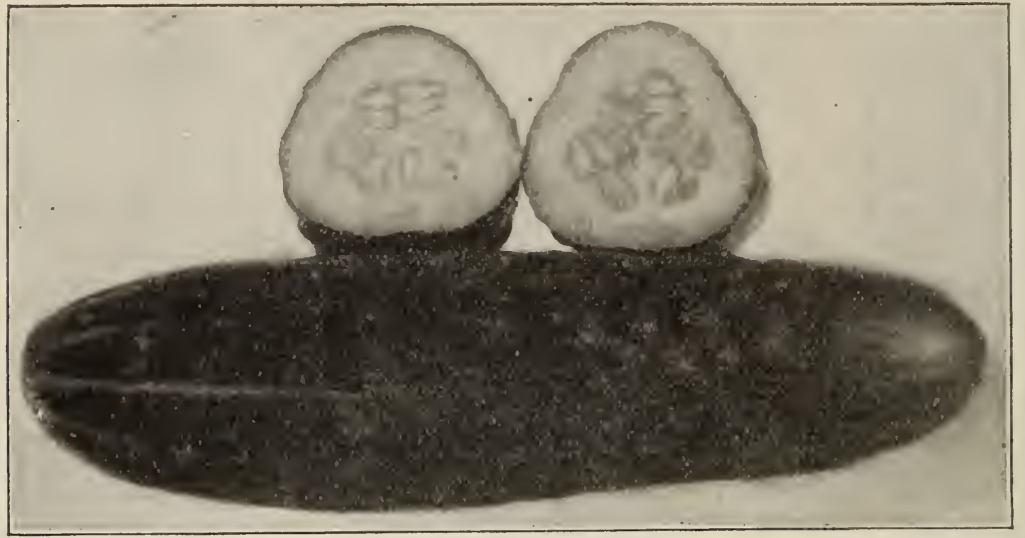

Evergreen White Spine. Ar improved strain of the well known White Spine, and a fav. orite with market gardeners, both for forcing and outdoor culture. It differs from the ordinary White Spine in the fact of always remaining of a deep green color in all stages of growth. Altogether it is a most welcome and valuable acquisition. for market or hoine use, and should be grown by all who have a garden.

Cool and Crisp. A strain of White Spine somewhat like the Arlington, but larger and less symmetrical.

The Emerald. It is strictly

EVERGREEN WHITE SPINE. an evergreen, retaining its color

until fully ripe. Its distinct dark green and spineless skin attracts attention.

Japanese Climbing. While all cucumbers are running vines, yet this variety is much more ereeping, or climbing in its habit.

Early White Spine. One of the best sorts for table use Vines vigorous, fruiting early and abundantly.

Arlington. A selection from the White Spine, being more pointed at each end.

Giant Pera. An exceedingly large growing sort, of excellent quality.

Chicago or Westerfield Pickling. A variety esteemed and grown extensively for the large pickling establishments.

West India Gherkin. A very small, oval prickly sort, distinct from all others.

Early Russian. Solid, with few seeds.

Improved Long Green. Fruit long and slim, not surpassed in quality by any variety.

Parisian Prolific Pickling. A slim and slender pickle from 3 to 5 inches long, covered with black, hairy spines.

Early Cluster. Vines vigorous, producing the bulk of the crop near the root and in clusters.

Green Prolific or Boston Pickling. A favorite with pickle growers and commercial gardeners, and good for table use.

Nichol's Medium Green. A valuable and handsome variety, in shape between White Spine and Long Green.

Early Frame or Short Green. An excellent sort both for table use and for pickling. Fruit straight, handsome, smaller at each end, bright green; flesh tender and crisp; and makes fine pickles.

Jersey Pickle. Sixty days to make pickles. It is productive, and is said to "green" better than any other variety, and to "hold color."

Thorburn's Everbearing. Small size, very early and enormously productive, and valuable as a green pickle. It continues to flower and produce fruit until killed by frost.

\section{CUĆUMBER PRICE LIST.} Prices include free delivery to your post of fice or express office. If to go with other
goods]at your expense by express or freight deduct 10 cents per Ib. from prices quoted.

\begin{tabular}{|c|c|c|c|c|c|c|c|c|c|}
\hline & $\begin{array}{l}\text { Pkt. } \\
\$ 0.05\end{array}$ & $\begin{array}{l}\text { Oz. } \\
\$ 0.10\end{array}$ & $\begin{array}{l}x=L b . \\
\$ 0.25\end{array}$ & \$1.00 & Parisian & $\begin{array}{l}\text { Pkt. } \\
\$ 0.05\end{array}$ & $\begin{array}{c}\text { Oz. } \\
\$ 0.10\end{array}$ & $\begin{array}{l}\frac{1}{3}=\mathrm{Lb} \\
\$ 0.25\end{array}$ & $\begin{array}{l}\text { Lb. } \\
\$ 1.00\end{array}$ \\
\hline Early White Spine. & & & & 1.00 & Chicago Pickling &.$\quad .05$ & .10 & .35 & 1.25 \\
\hline Arlington White Spine. & .05 & .10 & .25 & 1.00 & Early Russian.. & .05 & .10 & .35 & 1.25 \\
\hline Cool and Crisp....... & .05 & .10 & .25 & 1.00 & Early Cluster. & .05 & .10 & .35 & .1 .25 \\
\hline Davis Perfect. & 05 & .10 & 35 & 1.25 & Green Prolific & .05 & .10 & .35 & 1.25 \\
\hline The Emerald & 05 & 10 & 25 & 1.00 & Nichol's Medium Green & .05 & .10 & .35 & 1.25 \\
\hline Leonard's Greenh & .05 & .15 & .50 & 1.60 & Early Frame. & .05 & .10 & 35 & 1.25 \\
\hline Fordhook Famou & .05 & .10 & .25 & 1.00 & Jersey Pickle. & .05 & .10 & 35 & 1.25 \\
\hline Japanese Climbing & .05 & .10 & 35 & 1.25 & Thorburn's Everbearing & .05 & .10 & .35 & 1.25 \\
\hline proved Long & .05 & .10 & 40 & 1.50 & & & & & \\
\hline
\end{tabular}

\section{WE MAKE EVERYTHING PLAIN ON PAGE TWO OF COVER.}

Before sealing up your order be sure to read that page. You will then know what we do and what you are to do. Misunderstandings will thus be avoided and there will be no disappointment when the goods reach you. We guarantee to do our part if you will do yours. We cannot afford to have you dissatisfied with us. We Want Your Trade because we know that our goods will give you satisfaction. Our Prices are Right and we try to make our descriptions plain and straightforward. 


\section{DANDELION}

Cultivated or French Common. This is considered the best by many and is not at all the same as our wild dandelion, being greatly improved by careful selection. Pkt., 5c.; 0z., 20c.; 2 oz.; 35c.; $\frac{1}{4}$ lb., 60 c.; Ib., $\$ 1.75$.

Improved Thick Leaved. One of the earliest and best greens in cultivation. Pkt,, 5c.; 0z., 50c.; 2 oz., 85c.; $\frac{1}{4} \mathrm{lb} ., \$ 1.50 ; \mathrm{lb} ., \$ 5.00$.

\section{EGG PLANT}

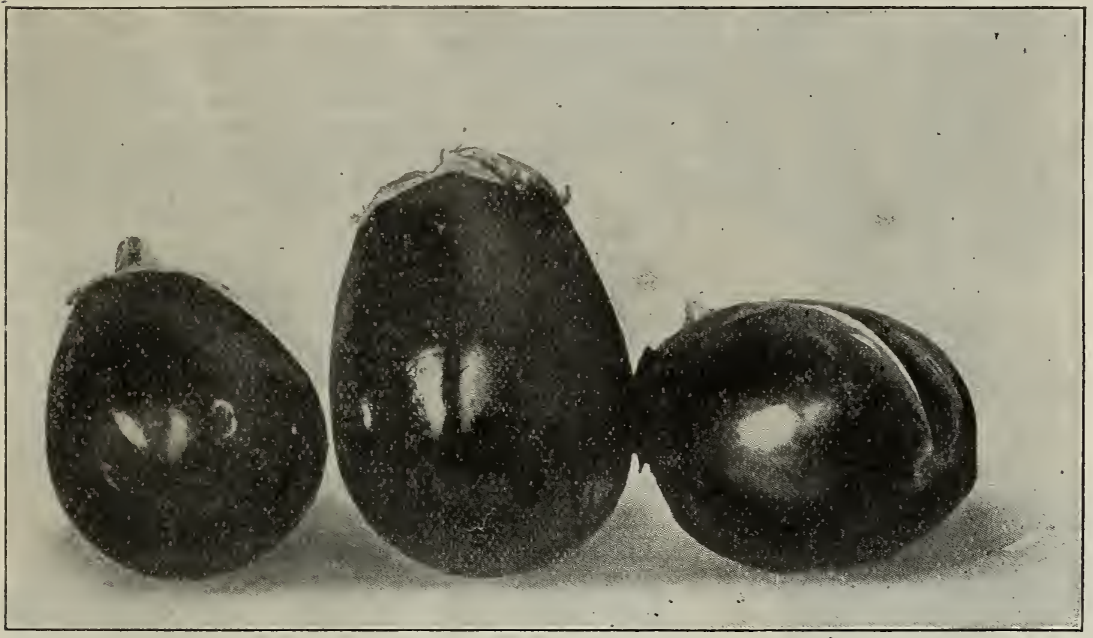

LEONARD'S IMPROVED NEW YORK PURPLE EGG PLANT.

Culture.-Egg Plant seed germinates slowly and should be started in strong heat, for in this, as in all subtropical plants, it is of importance to secure a rapid and continuous growth from the first, the plants never recovering from a check received when young. When the plants have formed two rough leaves, transplant to three or four inches apart. When the ground is warm and all danger not only from frosts, but from cold nights, is past, harden off the plants by gradual exposure to the sun and air, and decreasing the supply of water, then carefully transplant into the open ground, setting the plants two and a half feet apart.

Lecnard's Improved New York Purple Spineless. Very large and smooth, fine dark color. Ours is the spineless plant, most preferred by our market gardeners, both east and west. We have made the most careful selection possible of our stock plants, and know it to be unsurpassed for the market. Pkt., 5c.; oz., 25c.; $\frac{1}{4}$ lb., \$1.00.

Black Pekin. A fine variety, bearing large, round, deep purple fruits, fine grained, and of superior quality. Pkt., 5c.; 0z., 25c.; $\frac{1}{4}$ lb., 75c.

Early Long Purple. Early, hardy and productive; excellent for the table. Pkt., 5c.; 0z., 25c.

\section{ENDIVE}

Green Curled. Beautifully curled, tender and crisp. Pkt., 5c.; oz., 15c.; $\frac{1}{4}$ lb., 40c.; lb., \$1.00.

Moss Curled. More finely curled, and a heavier and more dense plant than Green Curled. Pkt., 5c.; 0z., 15c.; $\frac{1}{4}$ lb., 40c.; lb., \$1.00.

White Curled. Very tender when cut young; blanches readily. Pkt., 5c.; oz., 15c.; $\frac{1}{4} \mathrm{lb} ., 40 \mathrm{c}$; $1 \mathrm{lb} ., \$ 1.00$.

Broad=Leaved Batavian. (Escarrole.) This variety is chiefly used in soups and stews; requires to be tied up in blanching. Pkt., 5c.; oz.. 15c.; $\frac{1}{4}$ lb., 50c.

\section{FLORENCE FENNEL}

An excellent legume, with agreeable aromatic flavor, somewhat resembling celery, but with sweet taste and a more delicate odor. Very distinct from Common Fennel. It deserves to be used extensively. The thickened bases of the leaf stalks form a head or enlargement (see cut), firm, white and sweet. Height of plant, 2 feet. Pkt., 5c.; 0z., 10 c.

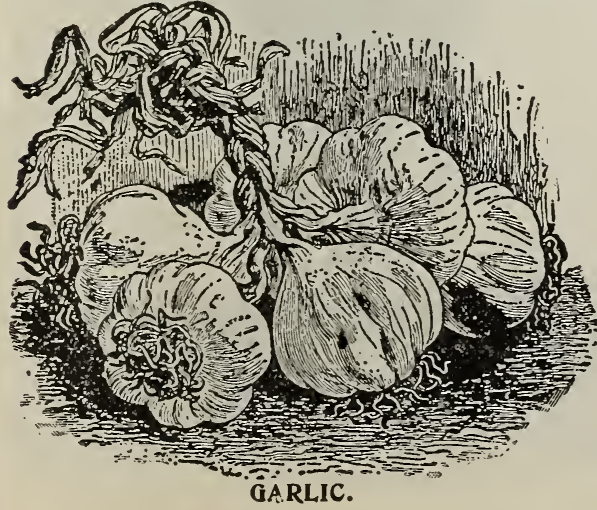

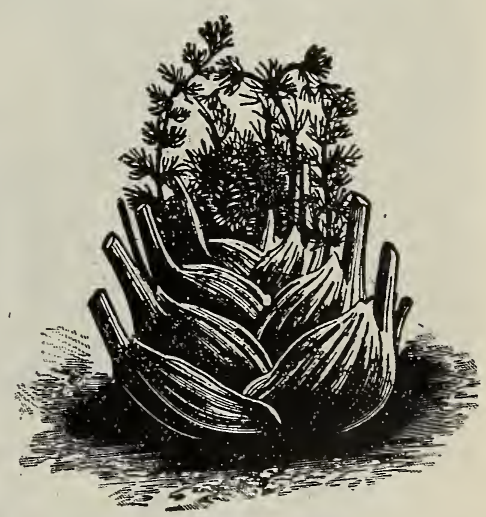

FLORENCE FENNEL.

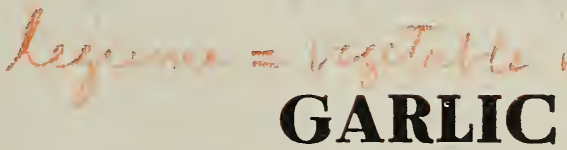

A bulbous rooted plant, with a strong, penetrating odor, but much esteemed by some for flavoring soups, stews, etc. We frequently receive orders for garlic seed, but we can only supply bulbs. Lb., 30c., postpaid.

By express or freight, at expense of purchaser. Lb., 20c.; 25 lbs., $\$ 4.00 ; 50$ lbs., $\$ 7.00 ; 100$ lbs., $\$ 12.00$.

\section{HORSE RADISH}

Yorse radish produces no seed, but is grown from pieces of the roots. Roots, per dozen, 20 c., postpaid. Roots per $1,000, \$ 5.50$. 


\section{HERBS}

SWEET, MEDICINAL.

To preserve varieties of which the leaves and stems are used, the stems should be cut from the plants just before the blossom appears (leaving a few joints at the base to sprout into fresh growth) tied in small bunches and hung up to dry. Where wanted for home use it is preferable to leave them hanging in a cool loft or garret until they are needed for use

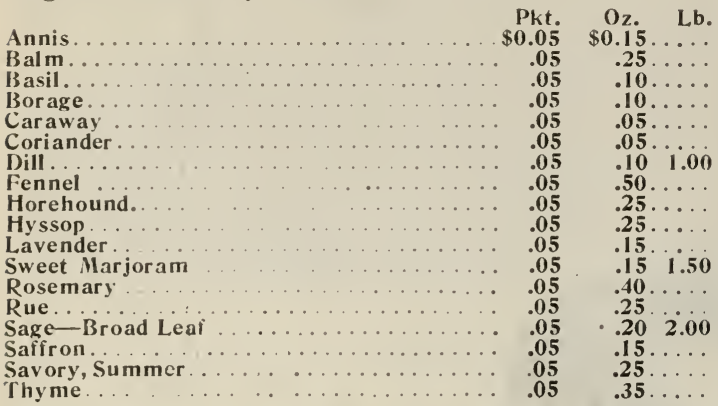

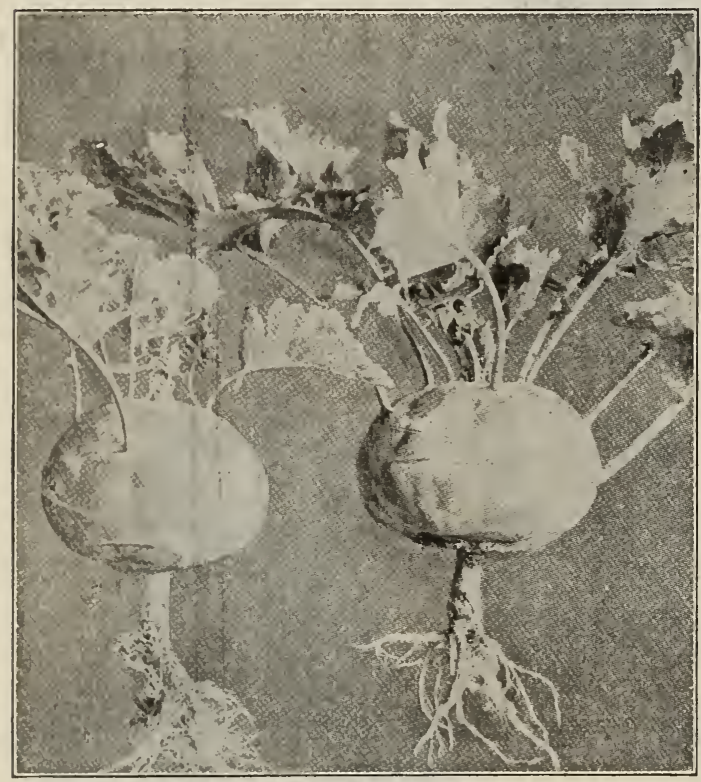

EARLY SHORT LEAVED WHITE VIENNA KOHL=RABI.

\section{KOHL-RABI}

Kohl-Rabi, Ger. Chou Rave, Fr. Col de Nabo o Nabicol, Sp.

One ounce of seed will sow a drill of about one hundred and fifty feet.

Earliest Erfurt. A white, tender variety, with a smooth root and very short top; the best variety for outdoor culture. Pkt., 5c.; oz., 20c.; $\frac{1}{4}$ lb., 50c.

Early Short Leaved White Vienna. The finest for market. Flesh white and tender. oz., 20c.; $\frac{1}{4}$ lb., 50c.

Early Purple Vienna. Bluish purple; similar to the above, except in color. Pkt., 5c.; oz., 15c.

Large Green. Hardy, quite late, and used for feeding stock. Bulbs large, weighing 8 to 10 pounds, whitish green in color; leaves large and numerous. Oz., 15c.; t lb., 50c.; lb., \$1.50.

\section{KALE or BORECOLE}

One ounce of seed will sow a drill of about two hundred feet.

Tall Green Curled Scotch. This is very hardy and is not injured by a moderate frost. About 30 inches tall, with an abundance of dark green leaves which are densely curled and cut, forming a very beautiful plant. It stands the winters in the Middle States without any protection. Pkt., 5c.; oz., 10c.; 2 oz., 15c.; $\frac{1}{4}$ lb., 25c.; lb., 75c.

Dwarf Curled ścotch. Plant low and compact, but with large, bright, deep green leaves, curled, cut and crimped until the. whole plant resembles a bunch of moss. One of the best sorts for use, and when well grown and cooked is one of the most palatable of vegetables. Pkt., 5c.; oz., 10c.; 2 oz., 15c.; 妾 lb., 25c.; lb., 75c.

Siberian. Sometimes called Sprouts and German Greens. In this variety the very large, green leaves are comparatively plain in the center but coarsely cut and filled on the edge. The plant is low but spreading and very hardy. Pkt., 5c.; oz., 10c.; 2 oz., 15c.; $\frac{1}{4}$ lb., 20c.; lb., 60c.

German Dwarf Purple. Similiar to the Dwarf Curled Sicotch, but of a rich purple color. Pkt., 5c.; oz., 10c.; 2 oz., 20c.; 妾 lb., 30c.; lb., \$1.00.

\section{LEEK}

London Flag. This is the variety generally cultivated in this country. It is hardy and of good quality. Pkt., 5c.; 0z., 10c.; 2 oz., 20c.; $\frac{1}{4}$ lb., 30c.; lb., \$1.00.

Large American Flag. A variety which has become very popular with some market gardeners on account of its being larger than the London Flag. Pkt., 5c.; oz. 15c.; 2 oz., 25c.; $\frac{1}{4}$ lb., 40c.; lb., \$1.25.

Large Rouen. Stem very large but comparatively short; the leaf is very broad, covered with whitish bloom. Stands a long time in condition for use. Pkt., 5c.; 0z., 15c.; 2 oz., 25c.; $\frac{1}{4}$ lb., 40c.; lb., \$1.25.

Monstrous Carentan. 'The largest variety, often 3 inches in diameter and becoming very white and tender. A hardy and desirable sort. Pkt.; 5c.; oz., 15c.; 2 oz., 25c.; $\frac{1}{4}$ lb., 40c.; lb., $\$ 1.50$.

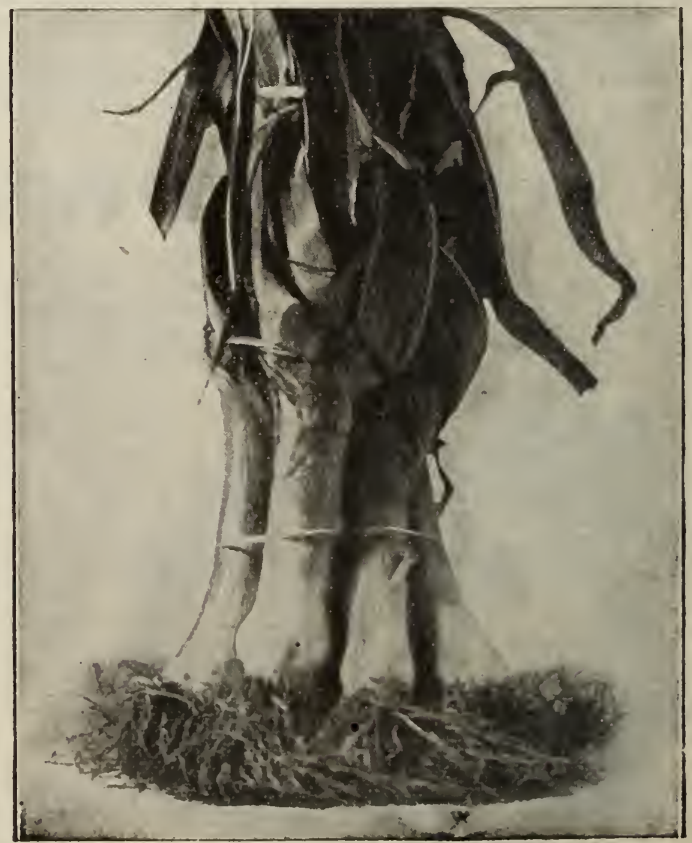

LOVDON FLAG LEEK. 


\section{LETTUCE}

Black Seeded Simpson. Forms large, loose heads. Leaves thin and exceedingly tender, of light green to golden yellow. Best sort for forcing or outdoor early planting.

Early Curled Simpson White Seed. Forms a close, compact mass of curly yellowish green leaves. Good for cold frames or early planting for outdoors.

Grand Rapids Forcing. Preferred by a great many to the Black Seeded Simpson, on account of being a tougher leaved lettuce. This makes it a fine sort for shipping, as it does not break so easily, and stands longer - without wilting.

New York or Wonderful. The large, white heads resemble cabbage in their solidity, and frequentiy weigh two and three pounds each. The quality is superb, being crisp, rich and tender.
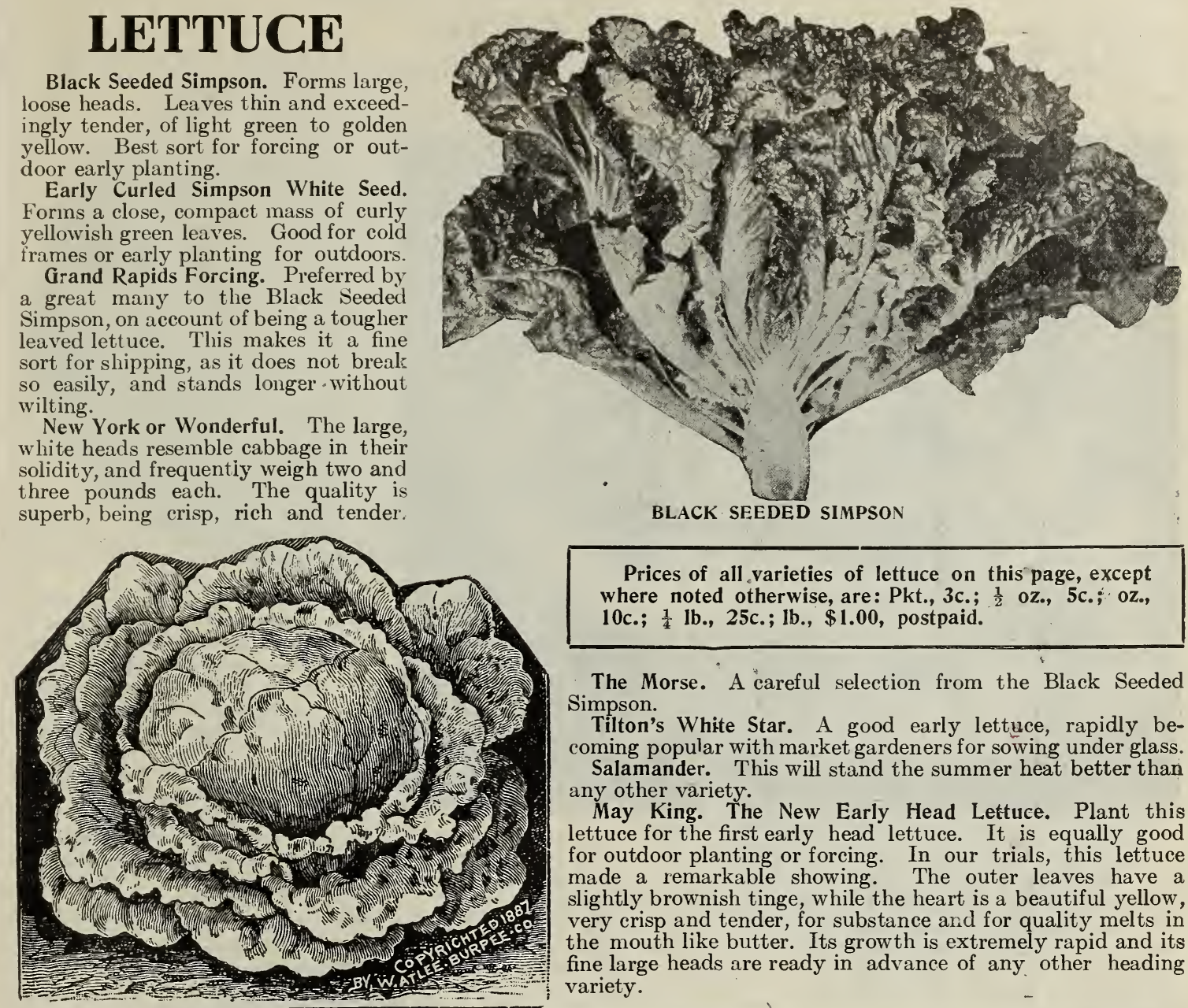

BLACK SEEDED SIMPSON

Prices of all varieties of lettuce on this page, except where noted otherwise, are: Pkt., 3c.; $\frac{1}{2}$ oz., 5c.; oz., 10c.; $\frac{1}{4}$ lb., 25c.; lb., $\$ 1.00$, postpaid.

The Morse. A careful selection from the Black Seeded Simpson.

Tilton's White Star. A good early lettuce, rapidly becoming popular with market gardeners for sowing under glass.

Salamander. This will stand the summer heat better than any other variety.

May King. The New Early Head Lettuce. Plant this lettuce for the first early head lettuce. It is equally good for outdoor planting or forcing. In our trials, this lettuce made a remarkable showing. The outer leaves have a slightly brownish tinge, while the heart is a beautiful yellow, very crisp and tender, for substance and for quality melts in the mouth like butter. Its growth is extremely rapid and its fine large heads are ready in advance of any other heading variety.
MAY KING LETTUCE

Iceberg. A beautiful lettuce. Large, curly leaves of bright, light green, with a very slight reddish tinge at the edges.

Brown Dutch. This variety is a good seller. Makes a round head tinged with red.

All Seasons. One of the best all head lettuces, standing the hot sun better than any other sort. Slow to seed. Handsome; good size; color, light green.

Denver Market. This is a fine crisp, crimpled head variety. It has a slight tinge of red. at the edges of the leaves. The ribs are a waxy white, being tender and free from bitterness.

Paris White Cos. The Cos lettuce differs entirely in shape from the other varieties, the head being elongated and of conical form, eight or nine inches in height, and five or six inches in diameter. The outer coloring of this variety is yellowish green. To be had in perfection it requires to be tied up so that the center leaves may be blanched.

Trianon Cos. Similar to the White Cos a favorite sort with French and Italian gardeners. The Cos varieties are becoming quite popular in this country.

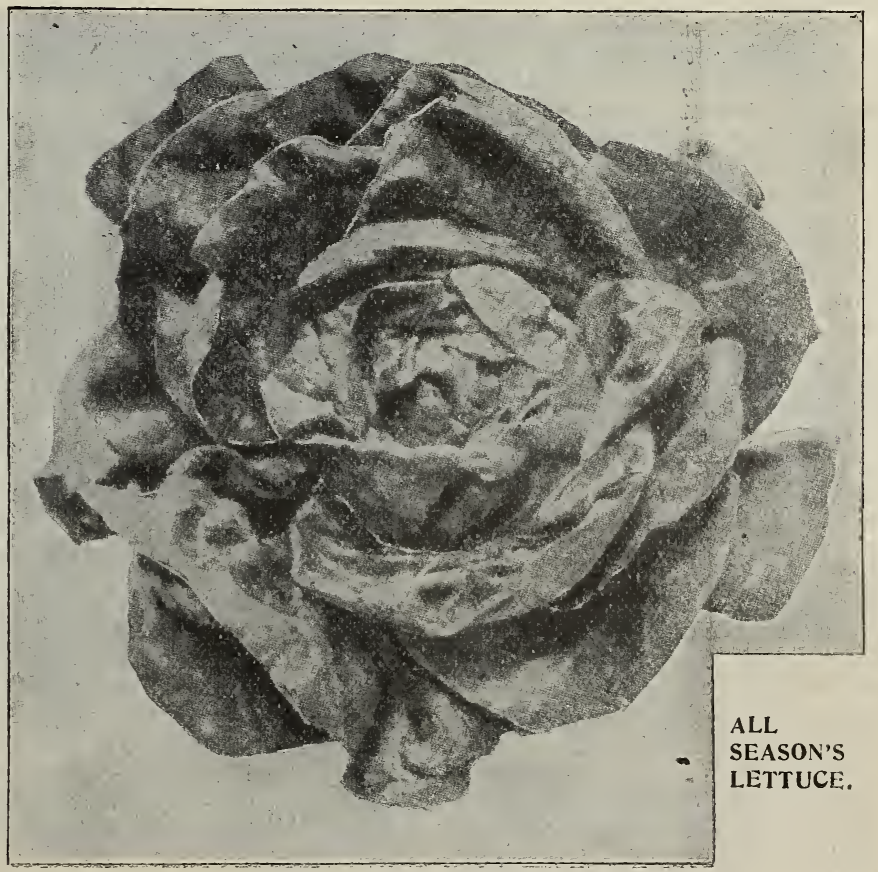




\section{FOR PRICES SEE BOT= TOM OF PAGE. \\ LETTUCE-Continued}

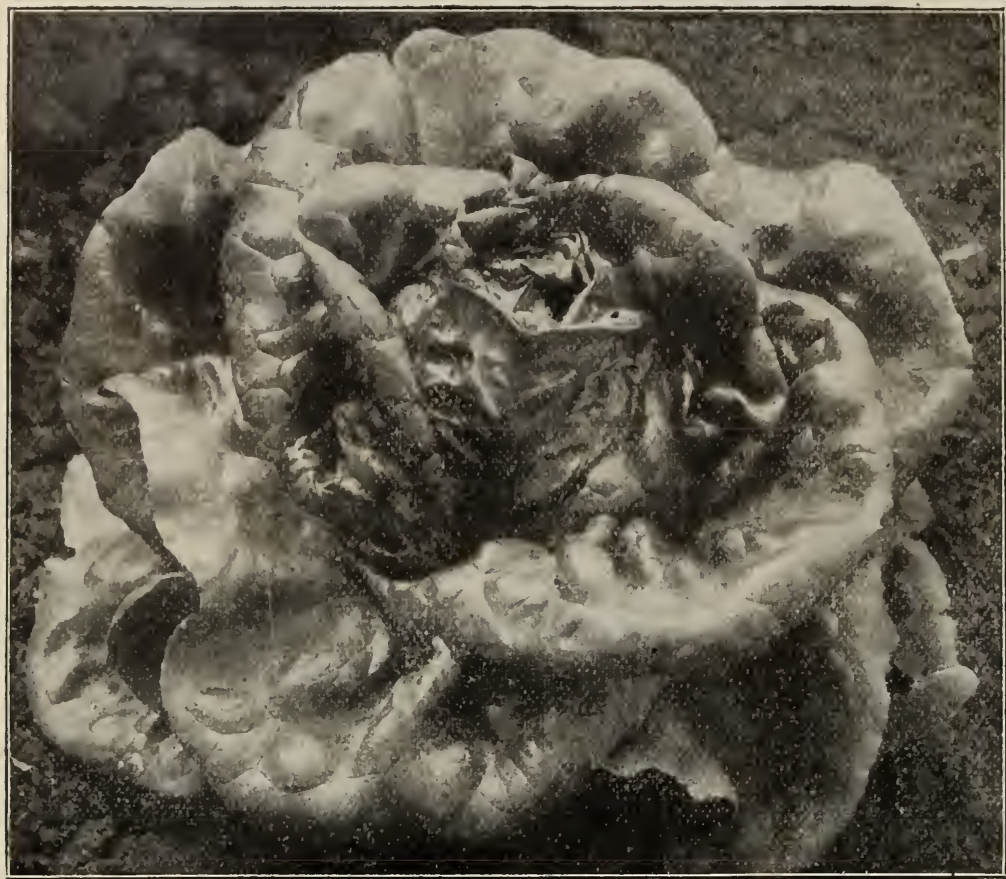

ST. LOUIS HEAD LETTUCE.

Precocity. An exceedingly early heading variety, compact, tender, solid and of fine quality.

Matador. Medium size; very solid head, medium early, tender, crisp and long standing.

Density. Very compact, can be planted six inches apart without crowding. Very attractive in appearance and of excellent quality.

Unrivalled. An improvement on the famous Big Boston Lettuce, possessing all the good qualities of this kind, viz.; earliness, large size, attractive color, etc. Its additional value lies in the fact that it can be sown almost the whole year round; it resists summer heat remarkably well; is crisp and solid when other sorts become tough and flabby under the same conditions.

Immensity This is an excellent large heading variety. It is slow to run to seed and maintains its crispness and tenderness longer than any similar kind. It is not early but is absolutely reliable for a late crop, and has good heat resisting qualities.

St. Louis Head. The most popular and satisfactory head lettuce with the Chicago market gardeners. It forms a fine head, is tender and crisp, and is very slow to run to

seed. Outer leaves are light green, and the inner ones are bright, creamy yellow, of a very fine flavor. Altogether, we recommend it as being the best head lettuce for general use.

The Deacon. A magnificent butter head lettuce. It stands the hot weather without becoming bitter or running to seed, and bears fine, large heads of superb quality. Light green outside, and, within, a beautiful cream yellow of delicious, rich, buttery flavor. Highly recommended for home or market use.

Prize Head. A good header. Solid and large.

California Cream Butter. A grand good butter lettuce. The heads are of good size, round and solid; outside, medium green; within, the leaves are a rich creamy yellow color. Rich and buttery in taste.

Hanson. Heads very large, from two to three pounds each; hearts quickly and stands the summer well; quality excellent.

Big Boston. This variety is identical in color, shape and general appearance with the famous Boston Market lettuce, but is double the size. It is about one week later in maturing, but its solidity and greater size of head will make it a most valuable sort. A most desirable variety, either for forcing in cold frames or open ground planting. The Big Boston is sure to be wanted by market gardeners and trucksters, because it always produces large, solid, salable heads, and will commend itself to amateurs because it heads up well at all seasons of the year, and is of crisp, tender quality.

Prices of all varieties of lettuce on this page, except where otherwise noted, are; Pkt., 3c.; $\frac{1}{2}$ oz., 5c.; oz., 10c.; $\frac{1}{4} \mathrm{lb}$, 25c.; lb., $\$ 1.00$, postpaid.

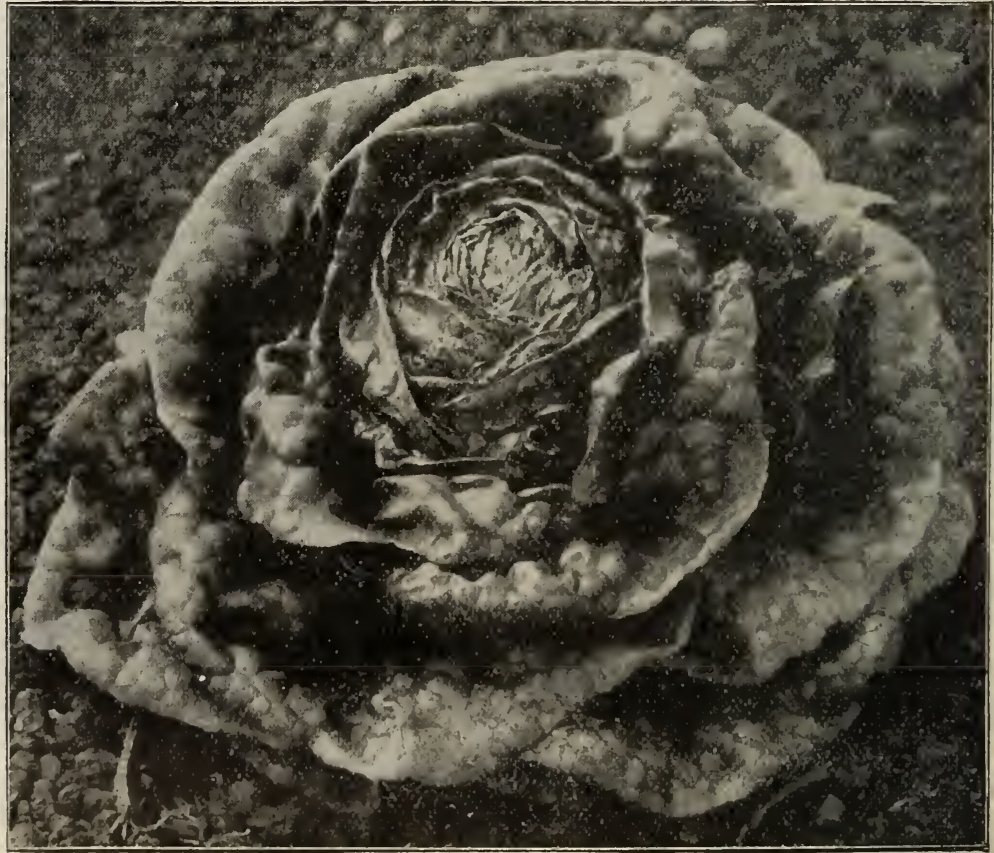

BIG BOSTON LETTUCE, 


\section{MUSK MELONS}

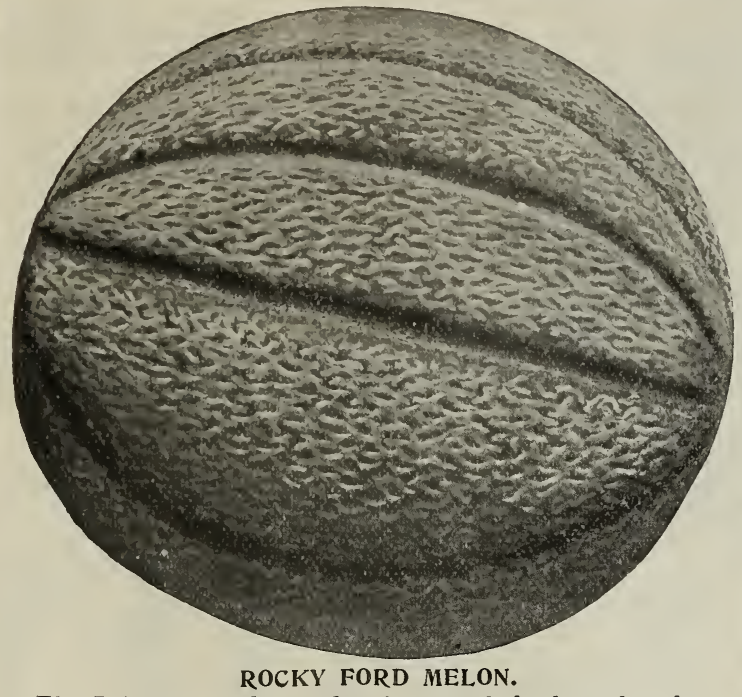

The Princess. This melon is one of the best for the home garden. In shape it is nearly round, with heavy netted dark green skin. The flesh is salmon color, thick, sweet and luscious.

The Osage. Is of medium size, oval in form, dark green in color, somewhat netted and slightly ribbed. The flesh is extremely and uniformly thick, of firm texture, rich salmon in color; highly flavored and delicious to the rind. Cavity very small. It is a remarkable keeper and a good shipping melon.

Emerald Gem Melon. The Emerald Gem is entirely unlike any other musk melon yet introduced. The melons are about the size of the Netted Gem, but, unlike that variety, the skin, while ribbed, is perfectly smooth, and of a very deep emerald green color. The flesh is of a suffused salmon color.

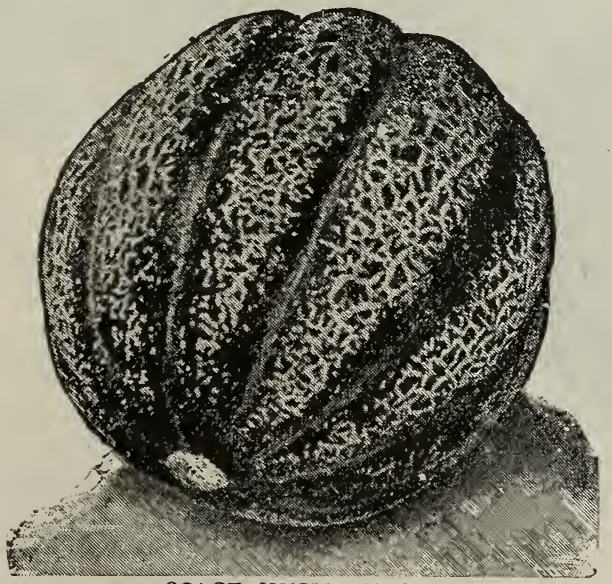

OSAGE MUSK MELON.

Banquet. A medium sized variety, nearly round, flattened at the ends, densely netted. Flesh dark rich salmon, uniformly thick.

Tip Top. A new melon of recent introduction, and very deserving. All who have tried it have pronounced it one of the finest. Flesh yellow and sweet.

Surprise. This old variety is still highly esteemed.

Delmonico Musk Melon. Oval-shaped, of large size, finely netted, and has beautiful orange pink flesh.

Paul Rose, Petosky or Salmon Fleshed Gem. This is the original salmon fleshed "basket" melon. It holds the same place in the salmon fleshed sorts as the Netted Gem does in the green fleshed.
Chicago Market. Fruit large, round and covered with dense netting. Flesh green, medium texture, very thick and sweet.

Rocky Ford. This musk melon is the oval strain of Netted Gem, brought into prominence by the melon growers in the vicinity of Rocky Ford, Colorado, who have shipped this melon from that distant western point to eastern markets. The melons grown by them are so fine in quality as to outsell all others, and the demand for such melons has been far beyond the supply.

Skillman's Netted. An excellent early melon with fine, tender flesh.

Netted Gem. The best early melon known. Shipped to every market of note, in great quantities, eve:y year. Medium size, but of excellent flavor.

Jenny Lind. A good early melon.

Early Hackensack. A green fleshed nutmeg, of excellent form. A very early and splendid melon.

Hackensack. A large, deeply netted melon, flattened at the ends, of most delicate flavor, and very productive.

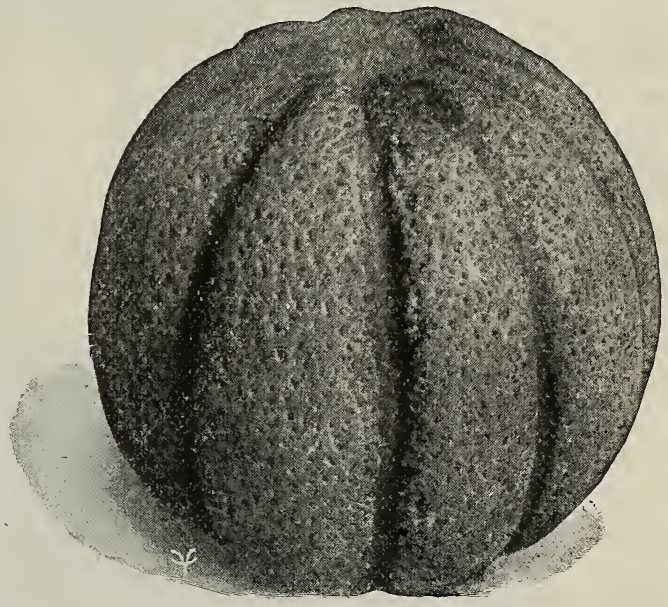

HOGBOO MELON.

Hoodoo. An improved form of salmon fleshed basket melon, distinct in many ways.

Burrell Gem. The originator says: "The new Rocky Ford Melon with Golden Meat." This describes the melon fully, as in appearance it looks just as the best types of green fleshed Gems, or Rocky Fords do.

Defender. Similar in all ways to the Paul Rose.

Admiral Togo. Practically the same as the Burrell Gem.

Ordway. Under the name of Ordway a golden meated Rocky Ford has been shipped into the Chicago market by the Colorado melon growers. It does not differ materially from the Burrell Gem.

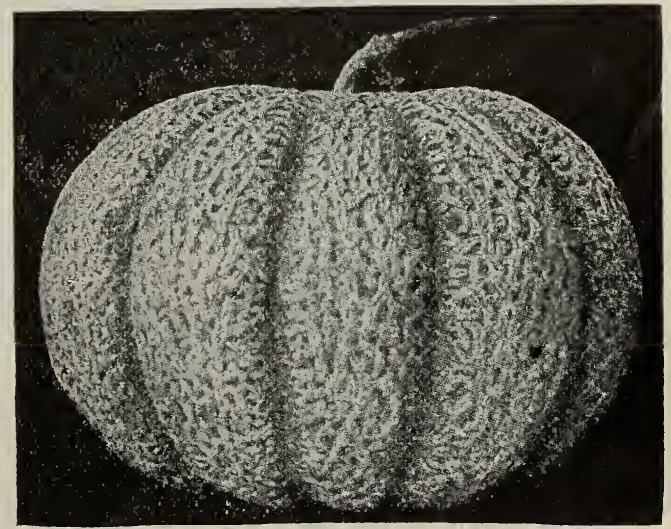

CHICAGO MARKET MUSKMELON 


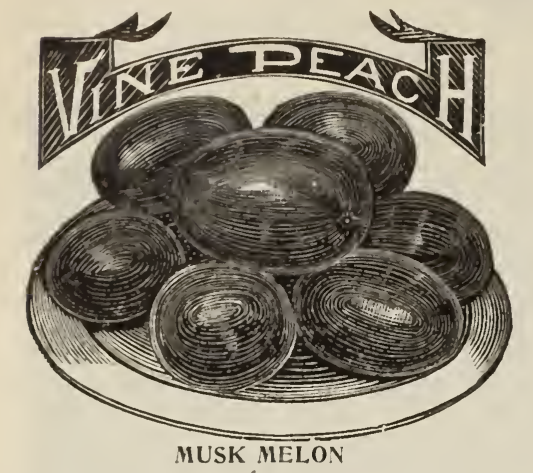

\section{MUSK MELONS-Continued}

Bay View. A large, prolific and fine flavored, green fleshed melon.

Acme or Baltimore. A very productive, oblong musk melon, that is guite popular in the Baltimore markets.

Green Fleshed Osage. Quality of the best, flesh a beautiful pea green; also a good shipper.

Champion Market. Shape almost round, deeply ribberl; skin heavily netted; flesh light green, rich and sweet.

Garden Lemon. An excellent fruit for preserving. Is shaped as shown in cut. Has a decided acid flavor. Pkt., 5c.; 0z., 15c.; $\frac{1}{4}$ lb. 40c.; lb., \$1.50.

Vine Peach. Very similar to Garden Lemon, and used for preserving. Pikt. 5c.; oz., 15c; $\frac{1}{4} \mathrm{lb} ., 40 \mathrm{c}$.; lb., $\$ 1.50$.

Ornamental Pomegranate. A very interesting and handsome fruited vegetable. Fruit similar to Vine Peach in size, color mottled and having a rich perfume. Pkt. 5c.; oz. 15c.; $\frac{1}{4}$ lb., 40c; Ib., $\$ 1.50$.

\section{PRICE LIST}

The packet, ounce and pound prices are for the seed prepaid by mail or express. Customers purchasing pounds or larger quantities

\begin{tabular}{|c|c|c|c|c|c|}
\hline & Pkt. & Oz. & Lb. & Lb. & 106 \\
\hline Rocky Ford ... & $5 \mathrm{c}$ & $10 \mathrm{c}$ & $25 \mathrm{c}$ & .80 & Ordway. \\
\hline Skill man's Netted. & $5 \mathrm{c}$ & $10 \mathrm{c}$ & $25 \mathrm{c}$ & .90 & Banquet \\
\hline Netted Gem. & $5 \mathrm{c}$ & $10 \mathrm{c}$ & $25 \mathrm{c}$ & .90 & Tip Top \\
\hline Jenny Lind. & $5 \mathrm{c}$ & $10 \mathrm{c}$ & $25 \mathrm{c}$ & .90 & Surprise \\
\hline Early Hackensack & $5 \mathrm{c}$ & $10 \mathrm{c}$ & $30 \mathrm{c}$ & 1.00 & Delmonico \\
\hline Hackensack...... & $5 \mathrm{c}$ & $10 \mathrm{c}$ & $30 \mathrm{c}$ & 1.00 & Chicago Market \\
\hline The Princess & $5 \mathrm{c}$ & $10 \mathrm{c}$ & $35 \mathrm{c}$ & 1.00 & Bay View ...... \\
\hline The Osage & $5 \mathrm{c}$ & $10 \mathrm{c}$ & $35 \mathrm{c}$ & 1.00 & Acme.. \\
\hline nerald Ger & $5 \mathrm{c}$ & $10 \mathrm{c}$ & $35 \mathrm{c}$ & 1.00 & Green Fie shed Osage \\
\hline oodoo.. & $5 \mathrm{c}$ & $10 \mathrm{c}$ & 30 & 1.00 & Champion Market... \\
\hline Burrell Gem & $5 \mathrm{c}$ & $10 \mathrm{c}$ & $30 \mathrm{c}$ & 1.00 & Garden Lemon. \\
\hline Defender. & $5 \mathrm{c}$ & $10 \mathrm{c}$ & 30 & 1.00 & Vine Peach. \\
\hline Paul Rose. & $5 \mathrm{c}$ & $10 \mathrm{c}$ & 35 & 1.0 & Pomegranate. \\
\hline Admiral Togo & $5 c$ & $10 \mathrm{c}$ & $30 \mathrm{c}$ & 1.00 & \\
\hline
\end{tabular}

\section{WATER MELON}

For Other Water Melons See Page 13

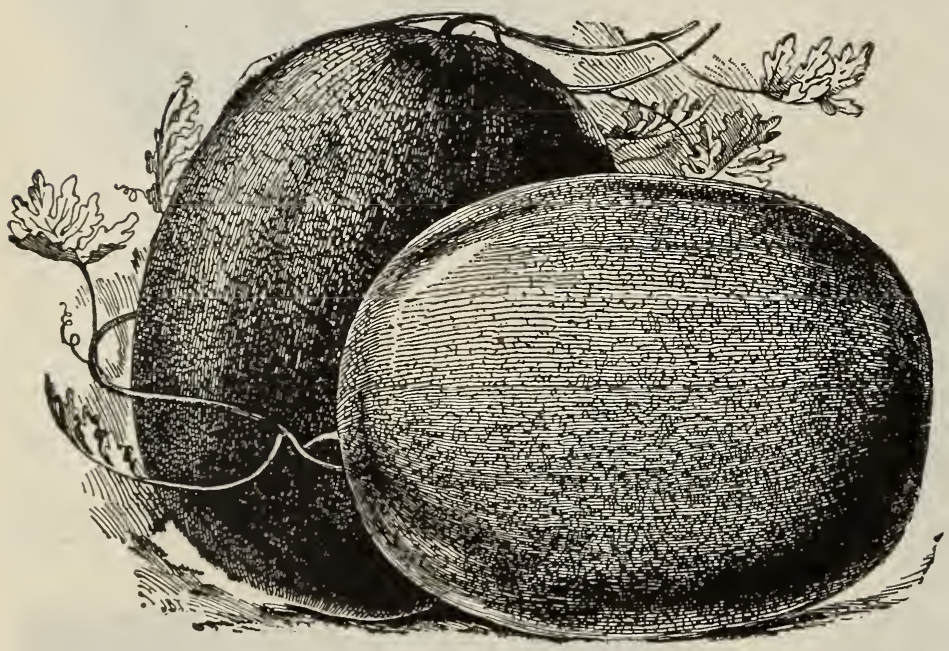

SWEETHEART WATER MELON.

Phinney's Early. Few, if any, of the early sorts of recent introduction surpass this old favorite. It is first to ripen, of good size and productive.

Vick's Early. 'This variety is prized for its earliness. It is oblong in shape, smooth with a very dark skin, rather small in size; flesh bright pink, solid and sweet.

Seminole. An exceedingly productive variety, of large size. Fruit oblong in shape; flesh solid, ripening clear up to the rind.

Gipsy, or Georgia Rattlesnake. One of the largest varieties, and stand shipment long distances. Fruit cylindrical, square at the ends, smooth, distinctly striped and mottled light and dark green.

Cole's Early. Very hardy, a sure cropper, and extremely delicate in texture of flesh, which is of a dark red color, possessing all the desirable features. Medium size, nearly round; rind green, striped with lighter shades.

Dixie. A popular market sort. Vine vigorous, large growing and hardy; fruit medium sized to large, about one-third longer than thick. Color of skin dark green, striped with a lighter shade.

Peerless. The old but extremely popular home market melon. There is none better, nor a more handsome melon grown.

Mountain Sweet. A large oval variety.

Pride of Georgia. Round, large, crisp; bright red flesh.

Jumbo. Immense in size. The common weight of this melon is 60 to 80 pounds. In shape it is nearly round; color solid dark green.

Mammoth Ironclad. This variety like the preceding, grows to an immense size. It is a remarkably strong grower, very productive and an excellent keeper. 'The skin is beautifully striped with light green.

Black Diamond. A cross between Kolb's Gem and Hoosier King.

Boss. Early and very large; a good shipper.

Kolb's Gem. Vines of medium size, but remarkably vigorous and healthy. Leaves of medium size, deeply cut with a peculiar frilled edge. Fruit of the largest size, round or slightly oval, marked with irregular mottled stripes of dark and light green. Outer rind or shell exceedingly hard and firm, making it a good sort for shipping long distances. Flesh bright red, solid, a little coarse, but sweet and tender.

Cuban Queen. Fruit medium size to large, globular or oval; skin striped light and dark green in sharp contrast. 


\section{WATER \\ MELON-Continued}

Sweet Heart. This melon is early, large, handsome, heavy and productive. The shape is oval, and color mottled light to very light green. See cut page 40 .

Black Spanish. Large, roundish, nearly black; dark red flesh; early.

Florida Favorite. A very large, long melon, mottled dark green, with stripes of lighter shade.

McIver's Wonderful Sugar Melon. Without a single exception this is the sweetest water melon of all.

Monte Cristo. A splendid sort. Vine vigorous and productive; fruit of medium size; oval; color dark, mottled green in two shades, forming indistinct stripes.

Prices of all Watermelons are: Pkt., 5c.; Oz., 10c.; $\frac{1}{4}=1 b$. 25c.; Lb., 85c., Postpaid.
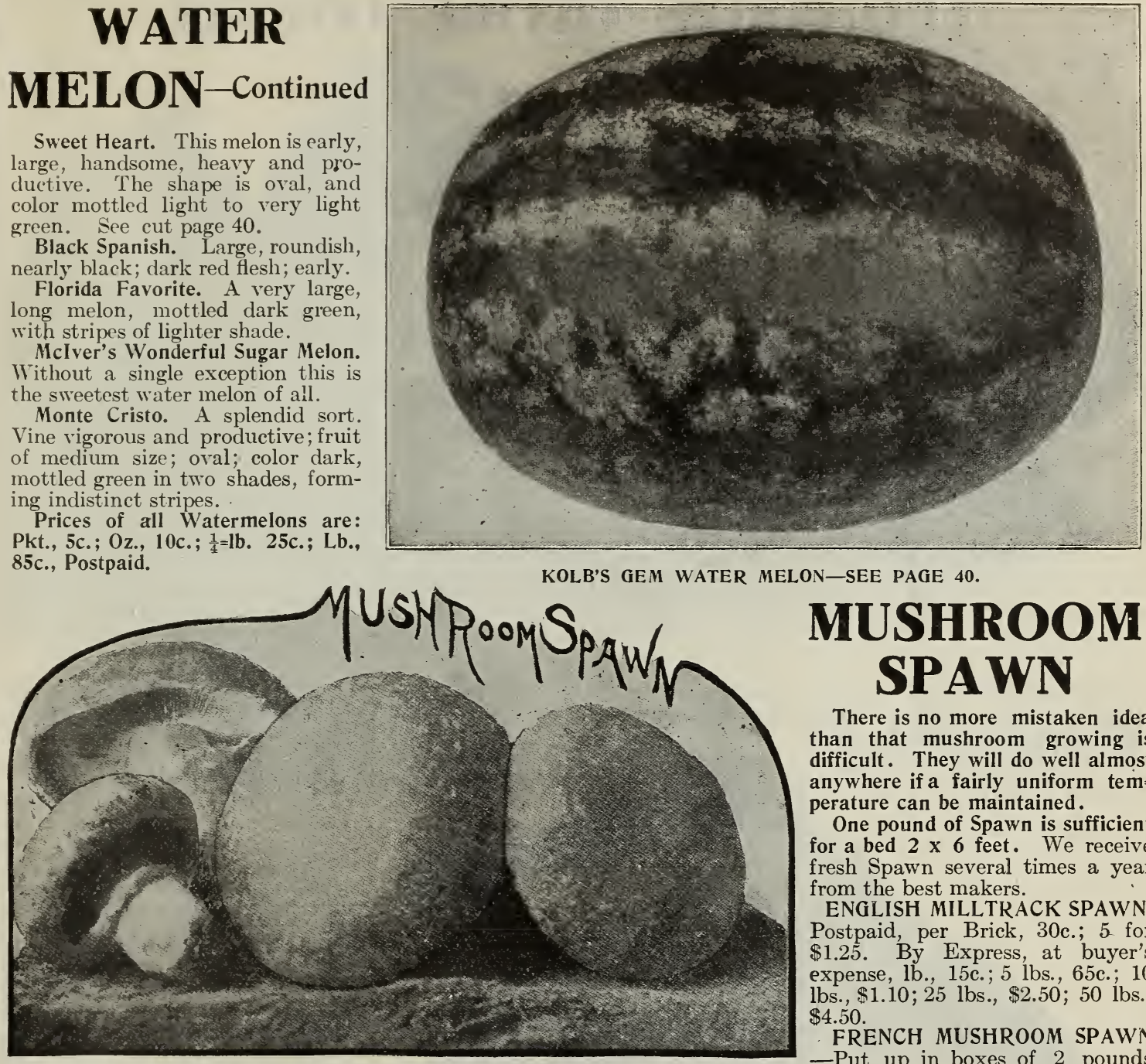

KOLB'S GEM WATER MELON-SEE PAGE 40.

each. Price per box, 75c.; by mail, $\$ 1.00$.

AMERICAN, PURE CULTURE, SPAWN-Produced by the new grafting process, from selected and most prolific varieties, has never failed to run. Per brick 35c., 5 for $\$ 1.50$, by mail, postpaid. By Express at buyer's expense, per Brick, 25c.; 5 Bricks, $\$ 1.00 ; 10$ Bricks, $\$ 1.85$.

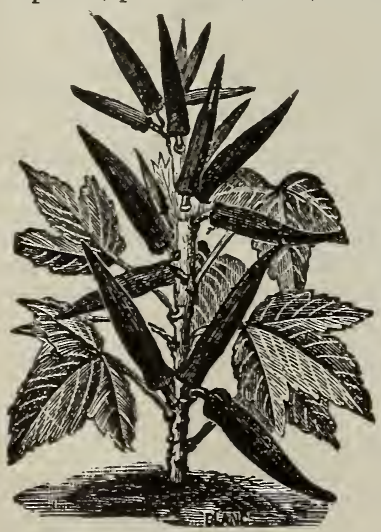

\section{MUSTARD}

Giant Southern Curled. The favorite in the South. Pkt. 5c.; oz., 10c.; $\frac{1}{4}$ lb., 20c.; lb., 65c. Chinese or Large Leaved Mustard. The large leaves, which often measure 14 inches, are ready for use in about six weeks after sowing. Plants will continue to yield until frosty weather. Leaves are eaten boiled. like spinach. Pk., 5c.; oz., 10c.; $\frac{1}{4}$ lb., 20c., lb., 70c.

White. Best for general use. Oz., 5c.; lb., 15c.; lb., 40c.

Brown. Stronger than above. Price,

\section{OKRA, OR GUMBO}

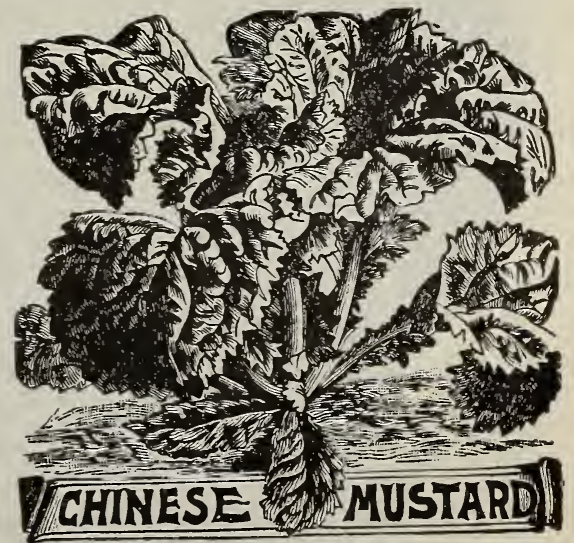

The young seed pots of this southern plant are used for the well known and delicious "Gumbo" soups, alone or with chicken.

White Velvet. Produces pods larger than any other. Pkt., 5c.; oz., 10c.; $\frac{1}{4}$ lb., 20c., lb., 60c.

Dwarf. Grows low but stocky and is very productive. Pkt., 5c.; oz., 10c., $\frac{1}{4}$ lb., 20c.; lb., 50c. 


\section{LEONARD'S GLOBE ONIONS}

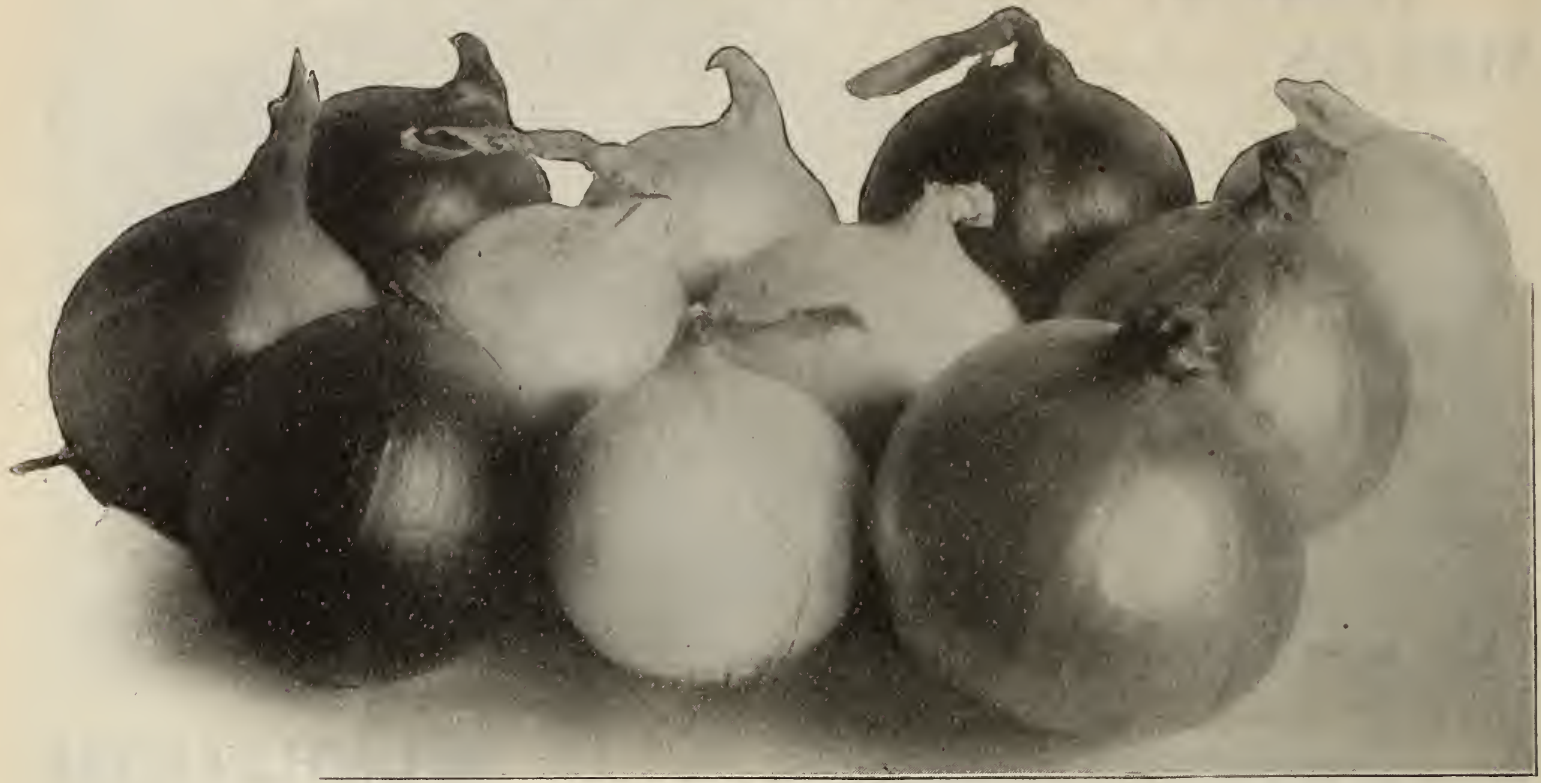

LEONARD'S THREE GLOBES

LEONARD'S THREE GLOBES. Ieonard's Three Globes bring more money to the onion grower and sell quicker than any other varieties. Our Yellow Globe is the Standard Yellow, our Red Globe is the Standard Red and our White Globe is the Standard White.

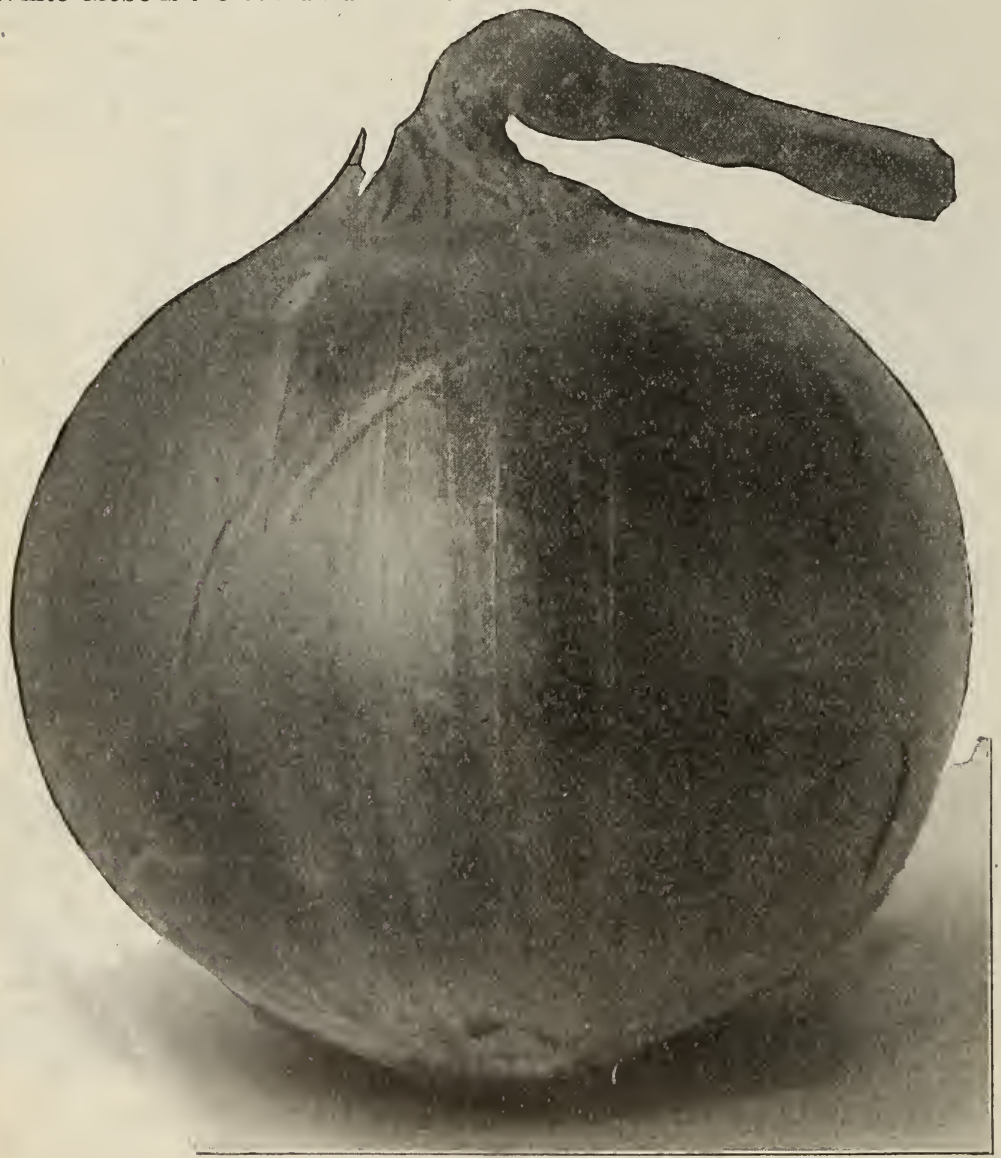

LEONARD'S YELLOW GLOBE.

This Onion is our prize yellow market variety. It is the most uniform as to size, the most productive, the best keeping and the handsomest yellow-skinned Globe variety we have ever known. It has taken years of patient effort to bring it to its present perfection, and to keep up the standard of excellence requires extreme care in the selection of bulbs to set out for seeding when the time for that event occurs each year. This onion has the call on the Chicago market, and our home sales for seed of it are very large. Last season our supply became exhausted long before the planting season was over. This year our supply is larger than it was last season, and we are prepared to meet in a measure the increasing demand for this splendid onion.

Good growers of onions seldom allow a difference in price to keep them from buying good seed if they feel sure that it is good. To such we would say: The seed here offered is worthy of investigation if a good thing is wanted.

Pkt. 5c; oz. 15c; $\frac{1}{4}$ lb. 50c; lb. $\$ 1.85$, postpaid.

By express.

5 lbs. $\$ 7.50 ; 10$ lbs. $\$ 15.00$;

25 lbs. $\$ 37.50$.

MARKET GARDENERS SHOULD

WRITE FOR OUR SPECIAL

ONION-LEONARD'S YELLOW GLOBE

MARKET GARDENERS CATALOG 


\section{LEONARD'S GLOBE ONIONS}

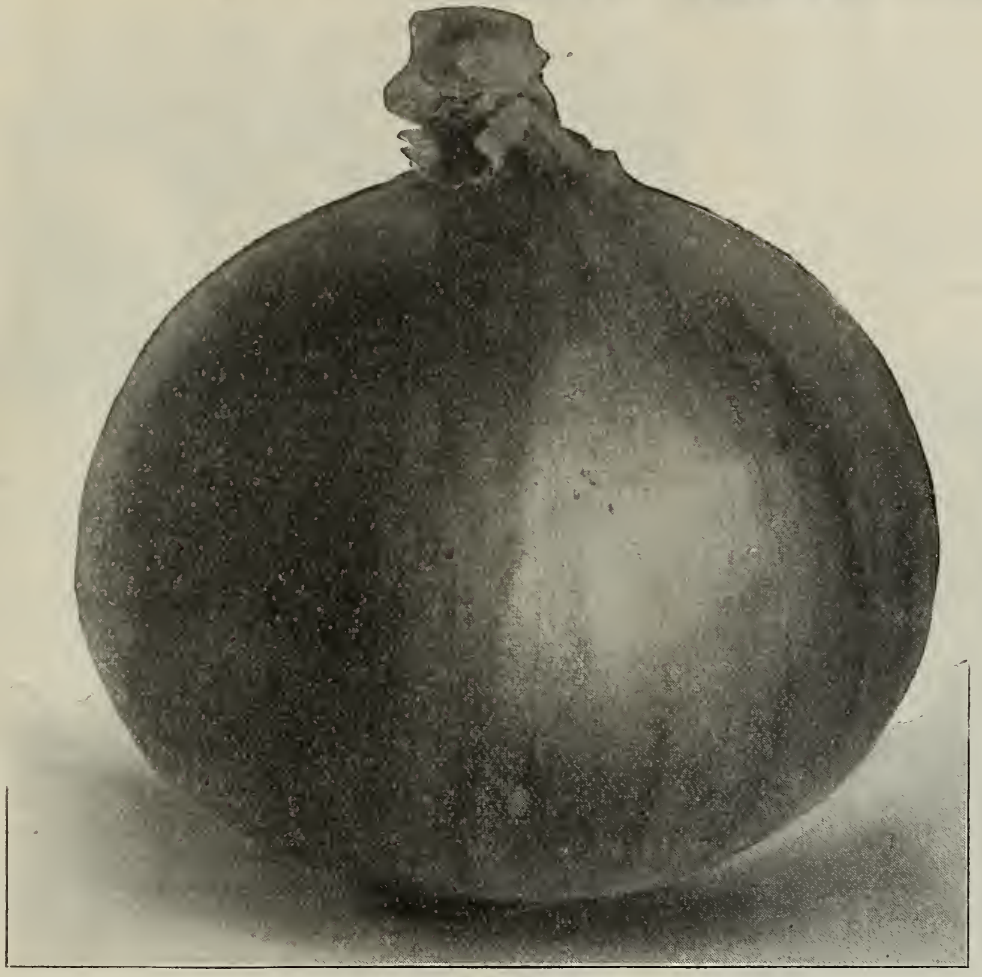

LEONARD'S RED GLOBE.

'The deep dark red color of our Red Globe is one of its superior points, while in shape and size it is a counterpart of our Popular Yellow Globe.

In the Michigan, Indiana and Ohio onion sections, as well as in Illinois and Iowa this strain of Red Globe produces the prize-winning red onions.

Where competition is keen it will pay large returns for the additional cost of the seed.

Pkt. 5c; 0z. 15c; $\frac{1}{4}$ lb. 50c; lb. $\$ 1.85$, postpaid.

By express.

5 lbs. $\$ 7.50 ; 10$ lbs. $\$ 15.00 ; 25$ lbs. $\$ 37.50$.

Superior stocks are necessary to the prosperity of the market planter. The inferior Article may be more attractive at the beginning, because it costs less, but the superior seed gives the more valuable product. You cannot afford to do without the best.

The Onion Seed Specialties here of fered are worth many times their cost to any market grower, and the satisfaction they will give to the consumer will increase the profits of the gardener who grows the pr
them.

\section{ONION—LEONARD'S RED GLOBE}

\section{LEONARD'S WHITE GLOBE.}

White skinned onions when successfully grown are by all means the handsomest and will usually bring more money per bushel than either of the other colors. It is harder to grow them to perfection than red or yellow, but many large growers score big returns from a crop of whites This strain of White Globe is uniform in size and shape with our Yellow and Red Globe.

Pkt. 10c; 0z. 25c; $\frac{1}{4}$ lb. 90c; lb. $\$ 3.00 ; 10$ lbs. $\$ 29.00$.

Our position as $M A R K E T$ GARDENERS' SEEDMEN is well and favorably known both at home and throughout the country. Our pre=eminent standing in this line of the Seed Business has been long established. The Market Gardener, when he plants LEONARD'S SEEDS, may therefore feel reasonably sure that he is planting the best seed obtainable.

During the past twenty $=$ six years in addition to the vast quantity we sell, we have each year planted and handled the product of thousands of pounds of onion seed. We plant the same kinds of seed that we sell, and sell the same kinds that we plant. We are growers of onions, as we plant. We are growers of onions, as well as sellers of the seed. We would satisfied to plant ourselves. We know what onions should be and we know the value of good seed.

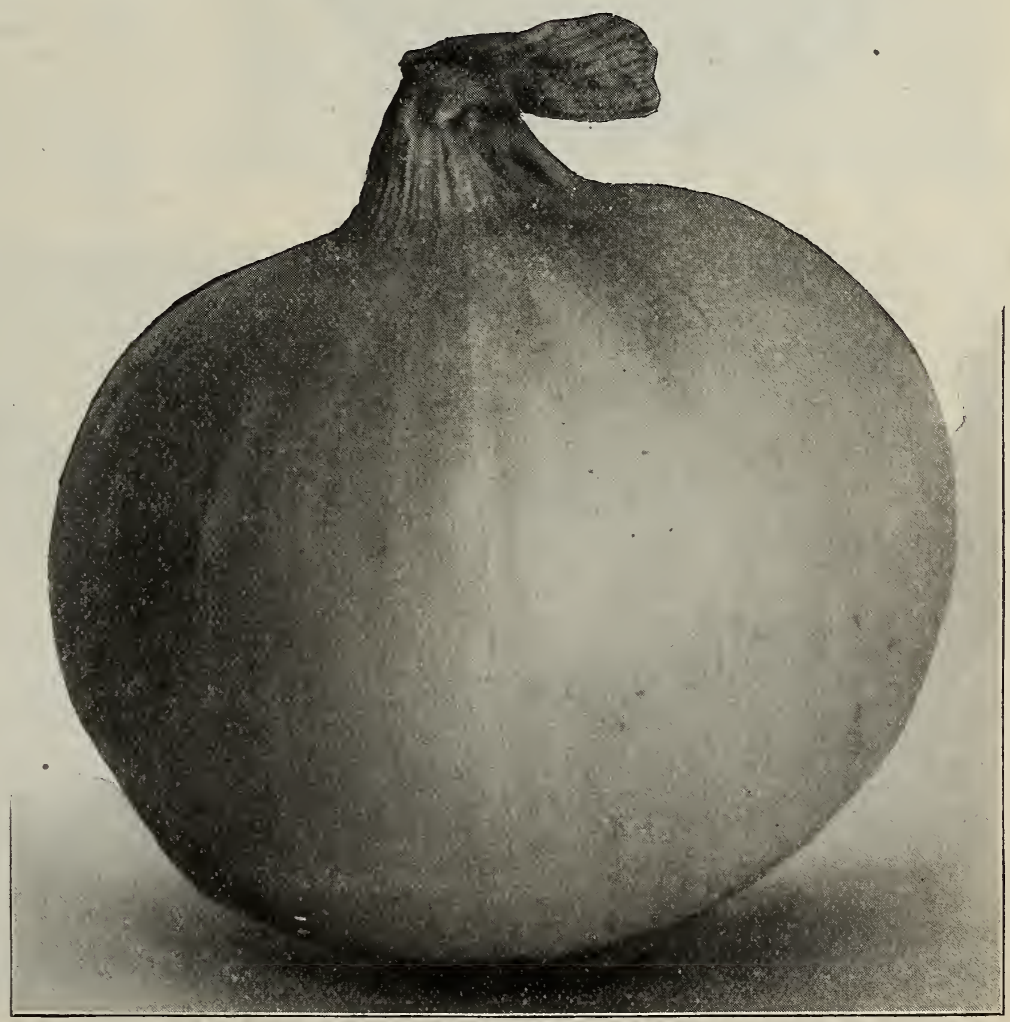

ONION-LEONARD'S WHITE GLOBE 


\section{ONION SEED - CONTINUED}

Large Red Wethersfield. We have a very fine and select strain of this sort. Color is deep purplish red, flesh white moderately grained and very firm. Yiclds an enormous amount per acre, and is one of the best winter keeping onions.

Extra Early Flat Red. This variety matures from ten days to two weeks earlier than the Red Wethersfield. The color is a deep rich red, fine grain and close.

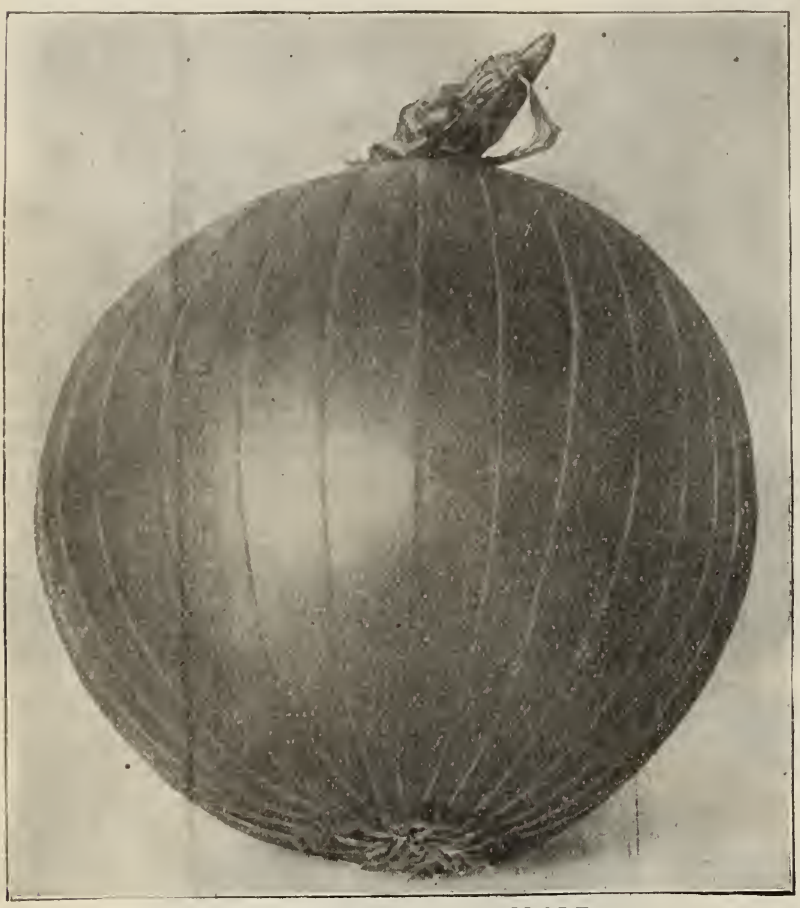

Early Flat Yellow Danvers. A good variety, but not as round or quite as early as the Yellow Globe Danvers. Very productive.

Yellow Strasburg, or Dutch. One of the oldest varieties. Bulbs quite flat, of good size, skin yellow, flesh white, of mild flavor and keeps well. This is the variety used very extensively for growing yellow onion sets.

Leonard's Yellow Cracker. 'The earliest, handsomest, and best flat onion in the list. Besides being early it is one of the best keepers.

Australian Brown Onion. Is of medium size, wonderfully hard and solid and most attractive for market, both as to form and appearance. The color of the skin is a clear amber brown.

Southport Yellow Globe. A large perfectly shaped Globe onion and an excellent onion for keeping throughout the winter. A very heavy cropper, handsome in appearance and good dark yellow color.

Yellow Globe Danvers. This fine onion is of large size. An early and abundant cropper. Bulbs very thick, flat or slightly convex bottoms, full oval top with small neck and rich brownish yellow skin.

Michigan Yellow Globe. The bulbs are large and uniformly spherical with very small necks and the largest diameter below the center of the bulbs of a rich orange color.

Ohio Yellow Globe. An early Globe onion, small neck and very uniform in size and color. Very popular in the marsh onion sections of Ohio and Indiana. We have an excellent stock of this standard variety.

Southport Red Globe. This is a fine keeper. Large size and considered one of the best red onions. Flesh is fine grained, very mild and tender.

White Portugal. American Silver Skin. This is the best sort to sow-for onion sets or for pickling. When sown thickly for either it makes a small, round, hard bulb.

Philadelphia Silver Skin. Tery desirable for ramily use. Flavor mild and pleasant. Skin silvery white. Sets grown from this sort are good keepers.

Soutinport White Globe. This grows to a very large size and is a perfectly globe-shaped onion. Color is a clear pure white. This variety is used by the Chicago market gardeners for bunching.

Spanish King. One of the handsomest onions grown. specimens weighing nearly four pounds are often harvested.

Silver King. This is a grand onion. It is a mammoth grower, of beautiful pearly white color, almost transparent in appearance. To match Spanish King at fairs and exhibitions it is just what is needed.

Copper King. 'This variety is the largest red onion grown. It is fine and mild in taste. With the two varieties above mentioned a combination is formed which wins prizes at all fairs for all colors.

Giant Yellow Rocca. Of all the magnificent Italian onions now in cultivation none are more popular than the Giant Rocca.

Giant Red Rocca. This magnificent variety is of beautiful globe shape, skin red, flesh white, of mild, pleasant flavor. Valuable either for autumu or spring sowing.

Prizetaker. Grows to an immense size and for fall marketing is unexcelled. Although of such great size, it is very hardy and a fair Winter keeper, as it ripens-up hard and firm; very fine grained, and of mild, delicate flavor. The outside skin is rich yellow while the flesh is white. To get the best results from this onion the seed is sown in beds and transplanted. It will, however, make a good crop if sown in the ordinary way.

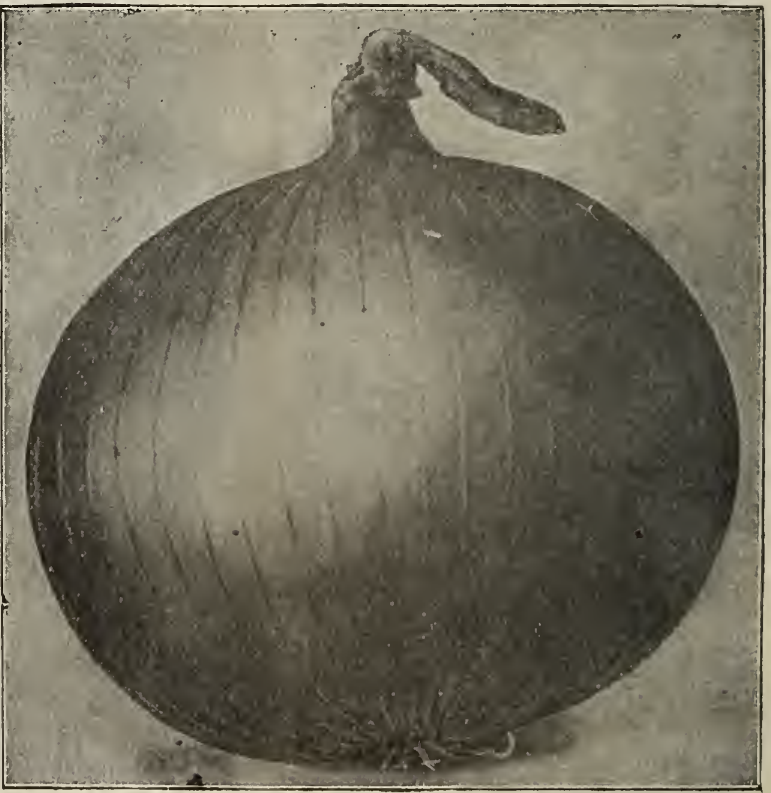




\section{ONION SEED-Continued}

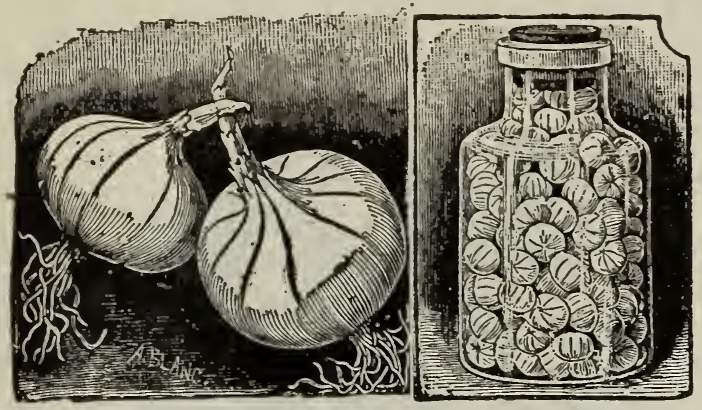

WHITE BARLETTA.

Extra Early Pearl. A very fine, Italian variety that grows quickly to a good marketable size. Very popular, particularly in the south. The bulbs are round, flattened, with a delicate pure white skin. Flesh very mild and pleasant in flavor. It is claimed to excel most other onions of Italian origin in keeping qualities.

New White Queen is a fine early silver skinned variety, of beautiful form and rapid growth, and possessing fine keeping qualities. Seeds sown in early spring will produce onions from one to two inches in diameter in early summer, or if sown in early summer will be fit for use by autumn.

Neapolitan Marzajola. A large, beautiful, silvery white skinned variety, of handsome flat shape, of very fine flavor and quality. Sown in February or March, it will produce a splendid crop early in the season. In May and June this onion has almost a monopoly of the markets in

Italian towns. Seed sown in July will mature a crop the same season.

White Barletta. When matured the tops die down, leaving beautiful and perfect little bulbs. The color is pure white, flavor mild and delicate, perfectly adapted for pickling and table use, and makes a pretty bunch onion, especially if grown by the transplanting method.

White Victoria. A beautiful, large round variety with silver white skin, but sometimes of a delicate light rose color; flesh juicy, sweet, and milky white. A good keeper.

Bermuda Red. A very early pale red onion, grown extensively in the Bermudas and southern part of the United States for early shipping to northern markets. Grown in our climate, the bulbs are smaller, but mature early and retain much of the mild, sweet flavor of the imported ones.

Bermuda White. Mild flavored; yellowish in color; otherwise same as red.

Crystal White Wax. This variety is popular at the south where the transplanting method of culture is practiced. A large, beautiful, silvery white skinned variety, of handsome flat shape, of very fine flavor and quality.

Write for prices on large quantities of onion seed for onion sets or for the pickling varieties. Market gardeners are entitled to have our special market gardeners price list.

\section{ONION PRICE LIST}

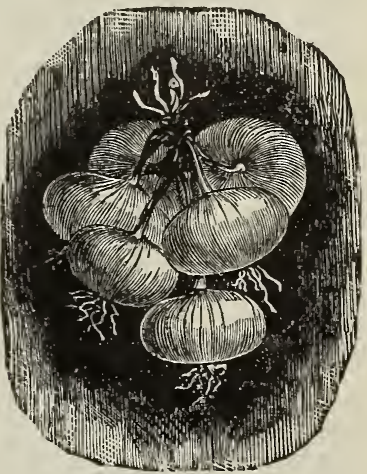

EXTRA EARLY PEARL.

Prices include free delivery to your post office or express office. If to go with other goods at your expense by express or freight deduct 10 cents per $1 \mathrm{~b}$. from prices quoted.

\begin{tabular}{|c|c|c|c|c|c|c|c|}
\hline 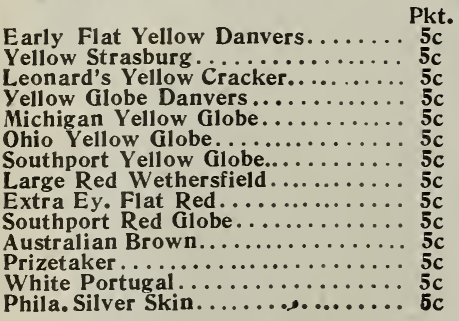 & $\begin{array}{l}0 \mathrm{z} . \\
15 \mathrm{c} \\
15 \mathrm{c} \\
15 \mathrm{c} \\
15 \mathrm{c} \\
15 \mathrm{c} \\
15 \mathrm{c} \\
15 \mathrm{c} \\
15 \mathrm{c} \\
15 \mathrm{c} \\
15 \mathrm{c} \\
10 \mathrm{c} \\
20 \mathrm{c} \\
20 \mathrm{c}\end{array}$ & $\begin{array}{l}1 \mathrm{Lb} \\
35 \mathrm{c} \\
35 \mathrm{c} \\
40 \mathrm{c} \\
40 \mathrm{c} \\
40 \mathrm{c} \\
40 \mathrm{c} \\
45 \mathrm{c} \\
40 \mathrm{c} \\
40 \mathrm{c} \\
40 \mathrm{c} \\
30 \mathrm{c} \\
60 \mathrm{c} \\
60 \mathrm{c} \\
50 \mathrm{c}\end{array}$ & $\begin{array}{l}\text { Lb. } \\
\$ 1.10 \\
1.10 \\
1.25 \\
1.25 \\
1.25 \\
1.35 \\
1.25 \\
1.25 \\
1.35 \\
1.25 \\
1.00 \\
1.60 \\
2.00 \\
1.85\end{array}$ & 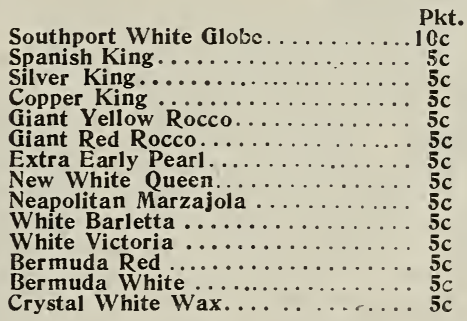 & $\begin{array}{l}0 \mathrm{z} . \\
20 \mathrm{c} \\
15 \mathrm{c} \\
15 \mathrm{c} \\
15 \mathrm{c} \\
20 \mathrm{c} \\
20 \mathrm{c} \\
15 \mathrm{c} \\
15 \mathrm{c} \\
15 \mathrm{c} \\
15 \mathrm{c} \\
20 \mathrm{c} \\
20 \mathrm{c} \\
20 \mathrm{c} \\
25 \mathrm{c}\end{array}$ & 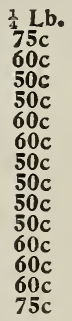 & $\begin{array}{r}\text { Lb } \\
\$ 2.50 \\
1.60 \\
1.50 \\
1.50 \\
1.50 \\
1.50 \\
1.50 \\
1.50 \\
1.85 \\
1.50 \\
2.00 \\
2.00 \\
2.00 \\
2.50\end{array}$ \\
\hline
\end{tabular}

Leonard's Onion Sets are the Chicago Standard. We are the pioneers in set growing here. We claim a superiority for our products which comes from superior knowledge in planting, harvesting, storing and shipping as a result of long continued experience and large operations.

\section{PRICES POSTPAID.}

Red Bottom Sets,

White Bottom Sets,

Yellow Bottom Sets,

Genuine Top Sets,

Winter Top Sets,

Potato Onions,

White Multipliers,

Shallots,

Yellow Multipliers.

Any variety. Pts. $15 \mathrm{c}$. ; qt., 25c.; 4 qts., 80 c.
ONION SETS

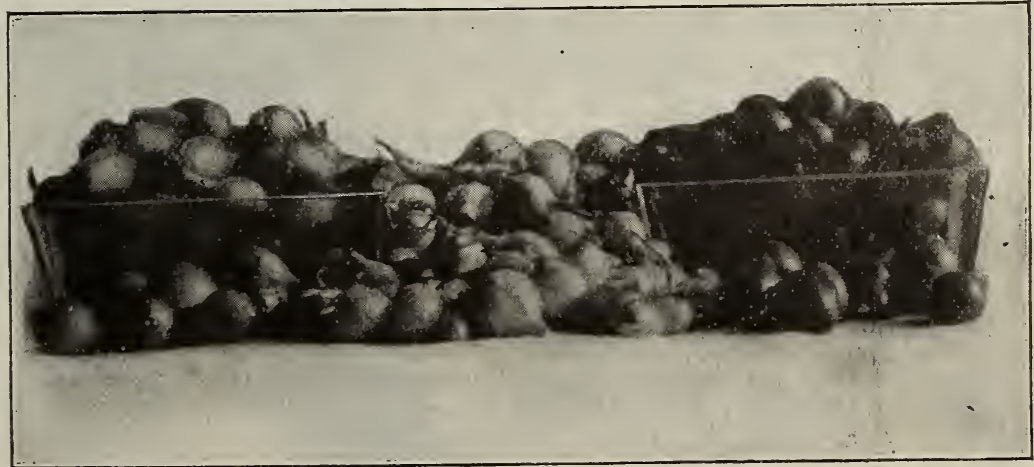

YELLOW

WHITE

RED

Peck and Bushel Prices-Vary. Write for Market Price. 
Notice. Wherever the number of days from planting to first picking for table use is given, the time is taken from our trial ground records made during the season of 1909 in Wisconsin Weather conditions, variations in soil and cultivation, as well as difference in latitude, will make either a longer or shorter périod of growth.

\section{PEAS}

Alaska. Well known and extensively used, especially by canners. Very early and when carefully grown, uniiorm in ripening. Vine is strong and vigorous, 2 to $2 \frac{1}{2}$ feet high, of a peculiar light green color; pods $2 \frac{1}{4}$ to 23 inches long, straight and blunt at the end, and light in color. Is ready for picking 49 to 50 days from planting. Seed round, blue, slightly pitted.

Ameer. Resembling the Alaska in appearance, 3 to $3 \frac{1}{2}$ feet in height. Pale green foliage. Pods 2 inches in length, pointed, dark green in color. Seed blue, dented medium green.

Bountiful. Resembling the Alaska in general habit of growth. Vine 36 inches, foliage gray green ; pods $3 \frac{1}{2}$ inches in length, pointed, gray green in color. Fit for table use 55 to 57 days from planting. Seed blue, medium pitted.

Claudit. In general habit and height of vine resembling Alaska, ripening almost at the same time, but with much longer, broader pods. Pods 3 inches in length, straight, handsomely shaped, and well filled at the point. Seed round, light green, dented, height $2 \frac{1}{3}$ feet.

Exonian. About 3 feet in height with pale green foliage, bearing small round blunt pods, medium green in color, about ten days later than Alaska. Seed green, wrinkled, small in size.

First and Best. Early, productive and hardy with a strong, vigorous vine, which is light in color and uniform in growth, $2 \frac{1}{2}$ to 3 feet in height and bearing straight pods $2 \frac{1}{2}$ to $2 \frac{3}{4}$ inches long, round, light in color and blunt at the ends. Is fit for table use 50 to 52 days from planting. Seed round, rather small, and white in color.

Maud S. A very fine extra early sort, hardy, productive and of good flavor.

Philadelphia Extra Early. One of the standard extra early sorts.

Rural New Yorker. Vigorous and very prolific.

Tom Thumb. A round seeded Pea, dwarf in habit, and desirable for garden culture, early and prolific, growing about one foot high, bearing pale green pods about $2 \frac{1}{2}$ inches long, round, nearly straight and well filled with peas of rather poor quality. Is fit to pick 56 days from planting.

American Wonder. Vigorous, productive vines, with a luxuriant foliage, and producing the leaves on one side of the stock, growing from 9 to 12 inches high. On account of its dwarf habit of growth it is very desirable for private garden use. Pods are light colored, straight, round, about $2 \frac{1}{2}$ inches long and blunt at the end. Fit for picking 55 days from planting. Seed is wrinkled, green, medium in size and square at the ends.

Nott's Excelsior. Resembling Gems in habit, but more dwarf and uniform in growth, height 12 to 17 inches, with rather light foliage. Pods are light in color, round, about $2 \frac{1}{2}$ inches long, blunt at the ends. Fit for picking 56 days from planting. Seed green, wrinkled, medium in size and square at the ends.

Witham Wonder. Vigorous, uniform in growth. Height 18 inches with larger, broader pods than American Wonder and well filled with peas of extra fine flavor. Pods 3 inches long, round, a trifle curved and slightly pointed. Seed medium sized, green, wrinkled.

Leonard's Clatawa. "Clatawa" is Chenook Indian for get up and get. It describes in a word the main characteristic of this wonderful new pea. The Clatawa is as early as American Wonder and bears pods like the Telephone, which certainly proves it to be a "get up and get" article. Its stocky vine and dwarf habit puts it ahead of anytling thus far brought out in the class of early wrinkled peas. Earliness combines witl productiveness, large pods grown on a short stocky vine is what makes the Clatawa unique among wrinkled peas. It will be a satisfaction to the market gardener while he picks it, and a source of profit when he sells it.

English Wonder. Vines vigorous in habit, 12 to, 18 inches in height. Medium green in color. Pods 3 inches long, slightly pointed, dark green in color. Fit for table use 67 to 69 days from planting. Seed blue green, wrinkled, medium size.

William Hurst. Resembling American Wonder in habit, but more straggling and uneven in growth. Height 16 to 18 inches, foliage dark, vigorous and productive, bearing in profusion. Curved pods, medium green in color, about 3 inches in length, fit to pick 57 days from planting. Seed green, wrinkled, medium in size.

Laxtonian. Vine $1 \frac{1}{2}$ feet in height with dark green foliage. Large curved dark green pods, pointed at the ends. Seed green, wrinkled, large sized.

Gems. Strong and vigorous in growth, producing vines from 18 to 24 inches in height, dark foliage, bearing pods singly on both sides of the stalk beginning near the ground. Pods are almost straight, $2 \frac{1}{2}$ to $2 \frac{3}{4}$ inches long, light in color and blunt at the ends. Ready to pick 59 to 61 days from planting. Seed is green, wrinkled, and medium in size.

Advancer. Vines upright and vigorous in growth, hardy and productive. Height 30 inches, foliage dark green, pods $2 \frac{1}{2}$ to $2 \frac{5}{8}$ inches long, round, dark colored and blunt, fit for picking 61 days from planting. Seed green, wrinkled, medium in size. A very fine pea for canners' use. 


\section{PEAS (Continued)}

Horsford's Market Garden. Strongly resembling Premium Gem in habit of growth, but about one-third taller. Vines growing 26 to 30 inches high, foliage dark green, pods light colored, straight, about $2 \frac{1}{2}$ inches long and blunt. Fit for picking 68 days from planting. Seed green, wrinkled, medium in size. A very popular pea with the canners and market gardeners on account of its excellent quality, being as sweet as Telephone and very much more tender.

Abundance. Vigorous in growth and productive, bearing pods in great abundance, although of medium size, and of excellent quality. Very similar in every respect to Horsford's Market Garden, except that it is about a week later, being fit for picking 71 days from planting. Pods are dark green, and blunt. Seed green, wrinkled, medium in size.

Duke of York. A pea of the same class as the Telephone, but earlier and more dwarf. The peas are sweet and of fine flavor.

Surprise. Resembling in vine, size and shape of pod Alaska and First and Best, but with the tender quality and delicate flavor of the best of the wrinkled sorts. Very much used by canners who wish an early pea with a sweet and delicate flavor. Vines $2 \frac{1}{2}$ to 3 feet high, light foliage bearing pods $2 \frac{1}{2}$ to 3 inches long, light in color and blunt at the ends. Can be picked 43 to 47 days from planting. Seed green, wrinkled and small in size.

Admiral. A long vine, medium season pea, bearing pods in profusion. About the same size and shape as First and Best, but of much better flavor. The small size and fine flavor of the pea, with its great hardiness, make it a most desirable sort for canners who wish a sweet wrinkled pea of small size. Vines 48 inches high, with medium green foliage. Pods $2 \frac{1}{2}$ inches long, medium light in color and blunt. Fit for picking 68 days from planting. Seed small, wrinkled, white.

French Canner. This is the small French Pea used for canning. Very prolific. Long, slim pods containing from 7 to 10 peas.

Gradus. A large, wrinkled, early pea with a pod nearly as large as Telephone, filled with large peas, tender and of good quality and flavor. Very quick to germinate and mature with the early sorts. This pea will not stand adverse conditions, however, as well as some of the other sorts, and seed must be planted after all danger of early frost has passed. Height of vine 26 to 30 inches, with large luxuriant foliage,
pale green in color. Pods dark green, 4 to $4 \frac{1}{2}$ inches in length and pointed. pale green in color. Pods dark green, 4 to $4 \frac{1}{2}$ inches in length and pointed.
Fit for table use 52 days from planting. Seed large, cream colored, wrinkled.

Thomas Laxton. Closely resembling Gradus in habit, rapidity of growth, earliness and foliage, 26 to 30 inches high, and much hardier in every respect than Gradus. Pods 4 to $4 \frac{1}{2}$ inches long, round, well filled with peas, blunt at the end. Fit to pick 52 days from planting. Seed large, cream colored, wrinkled.

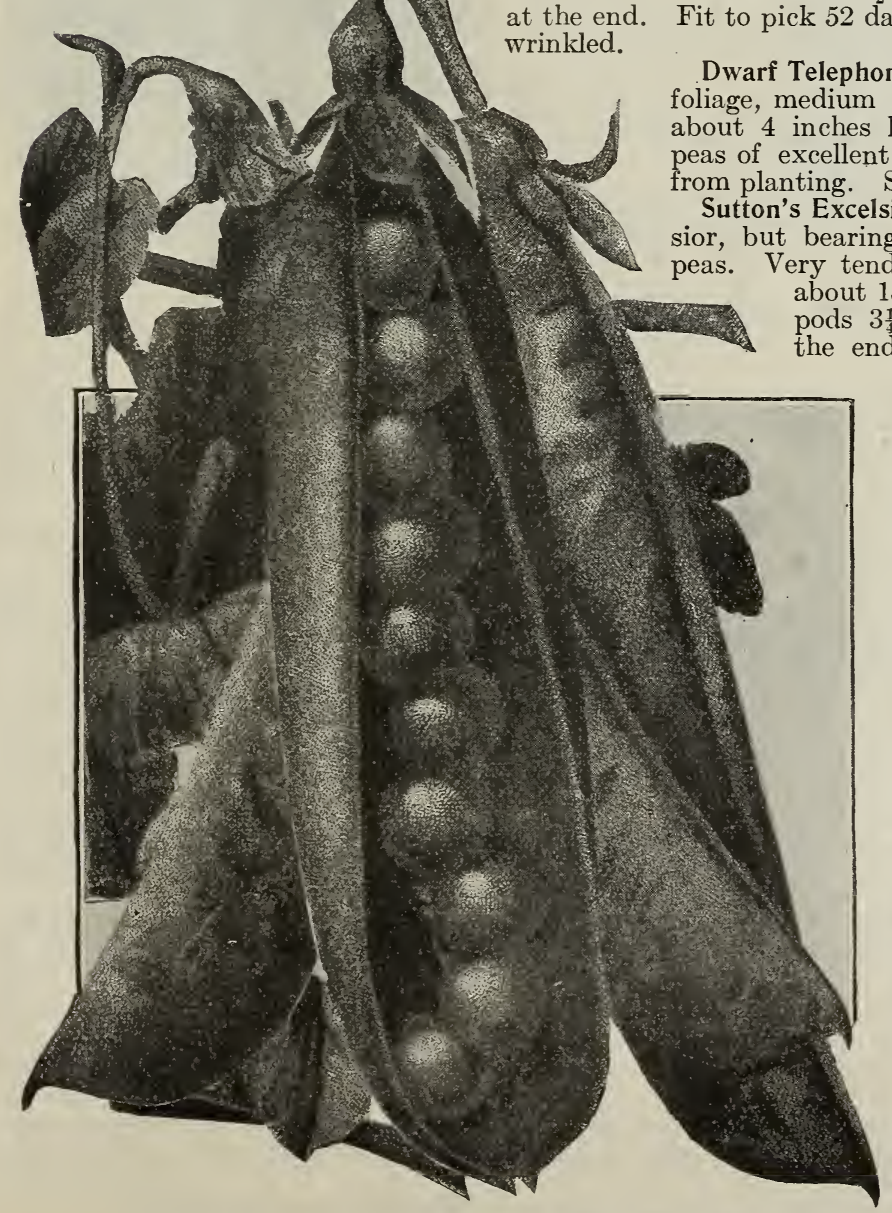

HORSFORD'S MARKET GARDEN (See Top of Page) days from planting. Seed green, medium sized, wrinkled. 


\section{PEAS (Continued)}

Leonard's Potlatch. Strong, vigorous vines of even growth, 20 to 24 inches in height, with luxuriant dark foliage, bearing pods medium green in color 31 to 4 inches in length. Broad and pointed at the ends. No variety known will produce more pods, and no pods could possibly shell out better. 'The Potlatch is a variety from which anyone may expect great things. Fit for table use 61 days from planting. Seed green, wrinkled, large in size. We consider ourselves very fortunate in having secured and introduced this pea.

Sutton's Dwarf Defiance. 'The vines, vigorous and hardy, about. two feet in height, with coarse dark green foliage, bearing long, broad pointed pods, dark green in color. Fit for picking 61 days from planting. Seed large, green, wrinkled. This pea is much more uniform in growth than the Stratagem, which it very closely resembles, and has the advantage of remaining fixed in its type, and showing practically no sports or runners.

Stratagem. A vigorous, hardy and luxuriant vine, bearing large pods containing peas of excellent quality. A heavy cropper, although it has a tendency to sport. Vines, 20 inches. Foliage, dark green. Pods $3 \frac{1}{2}$ inches long, straight, broad, pointed, gray green in color. Fit for table use 56 days from planting. Seed very large, green, wrinkled.

Pride of the Market. Of fine growth and general appearance, both vine and pod, and closely resembles the Stratagem except that the vine is not quite so long and the pods are deeper green in color. The vine is 20 inches high, foliage dark green color. Pods are $3 \frac{1}{2}$ inches long, broad and dark in color. Fit for table use 61 days from planting. Seed blue, slightly dented, large.

Heroine. Vines are strong and vigorous and produce an abundance of fine, large, well filled pods.

Telephone. Vines and leaves large and coarse. Foliage light green in color. Height 40 to 50 inches, pods $4 \frac{1}{2}$ inches long, broad, pointed, medium green in color. Fit to pick 62 to 65 days from planting. Seed large, green, wrinkled.

Duke of Albany. Resembling the Telephone in appearance. Vine and foliage medium green in color. Height 50 inches, pods 5 inches long, broad, pointed, dark green. Seed large, green, wrinkled.

Alderman. A large podded pea of the Telephone type, very robust and vigorous as to vine. Foliage, mixed, medium green. Height, 50 inches, pods 5 inches long, broad, pointed, medium green in color. Seed green, wrinkled, large.

Duchess. Height of vine, 4 feet. Medium green foliage, pods large, pointed, dark colored. Fit for table use 56 days from planting. Seed, dark blue, large, wrinkled.

Boston Unrivaled. Height $3 \frac{1}{2}$ feet, foliage medium green in color.

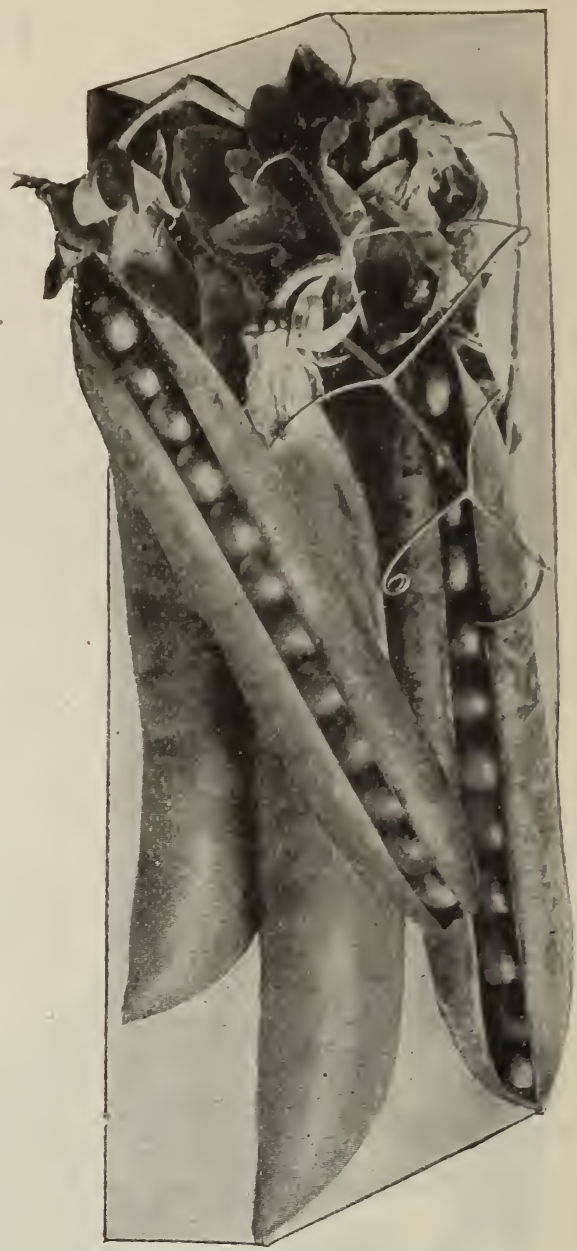

GRADUS (See Page 47) Pods large, pointed, pale green in color. Fit for table use 65 to 70 days from planting. Seed large, blue, green, wrinkled. Very similar to Duke of Albany and Alderman in habit.

Admiral Dewey. The largest podded pea yet introduced. Height, $3 \frac{1}{2}$ feet; pods a rich, dark green color, frequently six inches long, beautifully shaped. Peas large, tender and of first class flavor.

Sutton's Peerless. Vines 3 to $3 \frac{1}{2}$ feet in height, dark green foliage. Pods large, pointed and dark green in color. Fit for table use 75 to 78 days from planting. Seed large, blue, wrinkled.

Telegraph. Closely resembling Telephone in all respects, except that the pods are a deeper shade of green, and the peas are of only fair quality, although the pods are of very fine appearance. Pods 4 to $4 \frac{1}{2}$ inches long, medium dark green, pointed. Fit to pick 65 days from planting. Seed large, blue and round dented. color.

Long Island Mammoth. Very popular with market gardeners who want a large, handsome pod of a dark green

Champion of England. Strong and vigorous in growth, 42 to 50 inches in height. Foliage, medium green. Pods $2 \frac{1}{2}$ to 3 inches long, blunt, medium dark green in color. Ready to pick 68 to 73 days from planting. Seed large, green, very much wrinkled.

White Marrowfat. Vines hardy, strong, vigorous and bearing broad thick leatlery porls near the top of the vine, and containing peas of a poor quality. Height 45 to 50 inches, foliage light green in color, pods 3 inches long, blunt and light green. Ready to pick 69 days from planting. Seed large, smooth, white.

Black Eyed Marrowfat. Strong and vigorous vines bearing pods near the top of the vine. Peas of a poor quality Height 50 to 60 inches, light color foliage, pods 3 inches long, blunt, light green. Ready to pick 69 days from planting. Seed large, smooth, white with a black eye.

Melting Sugar. Large edible pod. Height, 42 to 48 inches. Pods, 4 to $4 \frac{1}{2}$ inches long and $1 \frac{1}{s}$ inches broad. Fit for table use 80 days from planting.

Improved Sugar Marrow. Much better than the old White Marrowfat. Pods larger, well filled and of the true marrow flavor.

Dwarf Gray Sugar. The old variety of the edible-podded sort, and is used in no other way. Grows about 2 feet high and is remarkable for its earliness. Pods are broad, flat and crooked and contain 5 to 6 peas. Seed is brown and wrinkled.

Tall Gray Sugar. A little later than the foregoing and somewhat taller; otherwise, they are similar, 


\section{PEAS (Continued)}

\section{Testimonials for Leonard's Potlatch Peas}

The following report, dated Chicago, July 30, 1906, from Dr. W. H. Stennett, Auditor of Expenditures, Chicago \& Northwestern Railway Co., and who is also a specialist in amateur gardening, is a comprehensive, concise and valuable testimonial "POTLACH. - Sown May 15, 15 inches high, foliage a very dark green, bloomed July 4 , fit to eat July 22 , pod and grain large, sweet and excellent. When cooked, they were the greenest pea I have ever seen; in fact, greener than any 'French' pea that all know are made green by chemicals.-W. H. STENNETT.'

\section{What Others Say}

"Your Potlatch is the best pea I have ever had both for quality and productiveness."

"'The finest Early Pea we ever planted.'

"The quality of your Potlatch equals Champion of England.

"Your Potlatch is the most productive Early Pea we ever tried."

"In earliness and productiveness combined with quality, your Potlatch leads all."

"I am glad that I took your advice for the Potlatch Peas I bought from you gave me excellent satisfaction,'

The Peck and Bushel Prices of Peas Vary; Customers Needing These

\section{Quantities Should Write for Special Prices}

\section{Prices of Peas-Postpaid.}

If to go with other goods at expense of purchaser, de= duct $15 \mathrm{c}$ per qt. or $8 \mathrm{c}$ per pt.

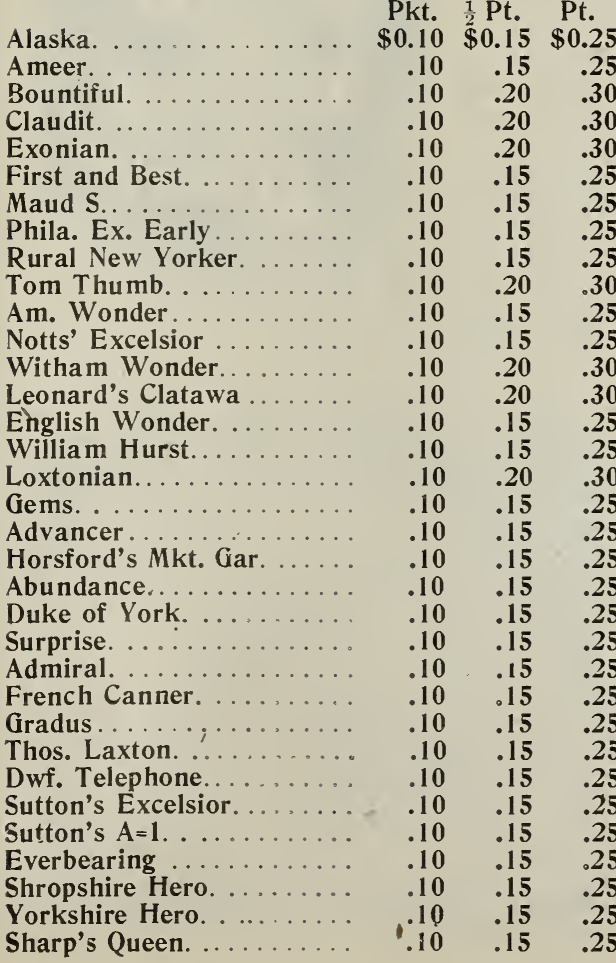

.40

.40

.40

.45

.40

.40

.45

.45

.40

.40

.45

.40

.40

.40

.40

.40

.40

40

.40

.40

.40

.40

.40

.40

.40

.40

.40

.40

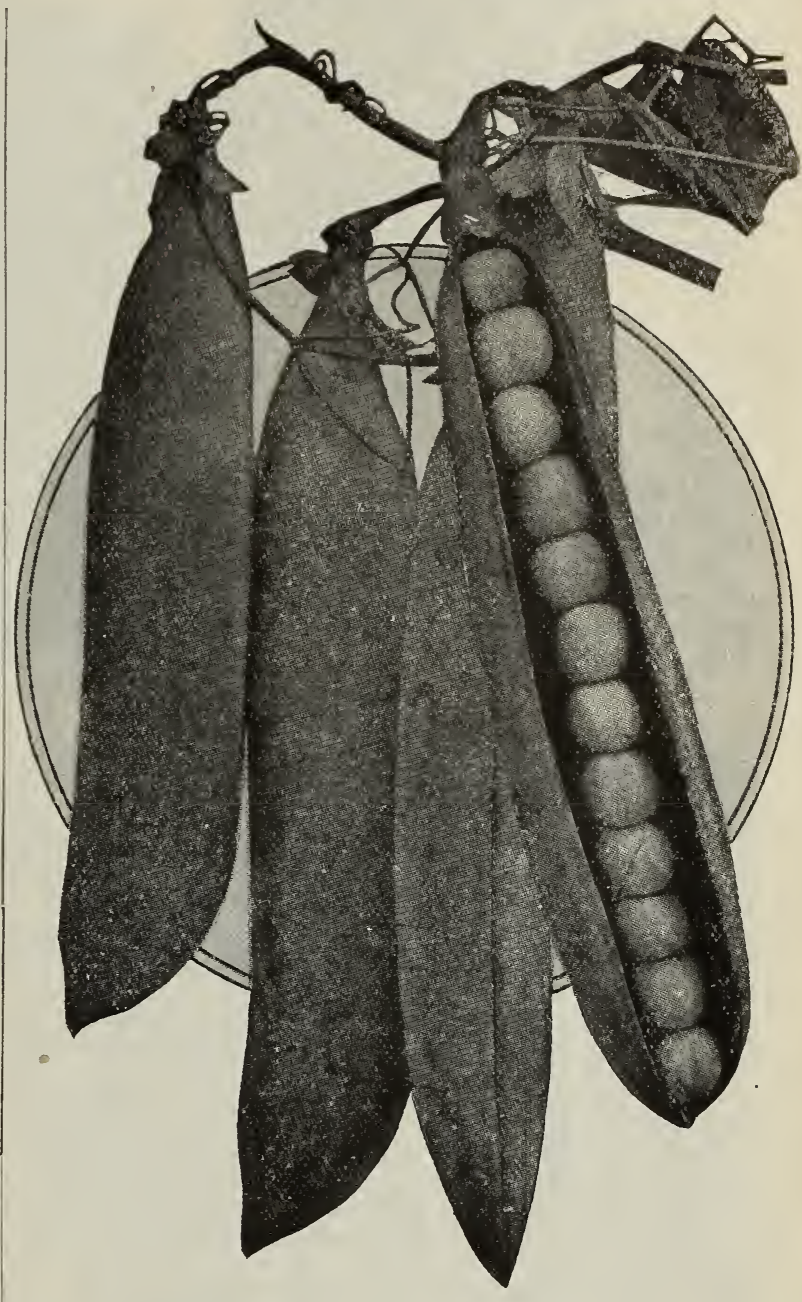

LEONARD'S POTLATCH PEAS (See top of page )

Pkt. $\frac{1}{2}$ Pt. Pt. Qt.

Leonard's Potlatch........ $\$ 0.10 \$ 0.15 \$ 0.25 \$ 0.40$

Sutton's Dwf. Defiance... $\quad .10 \quad .15 \quad .25 \quad .40$

$\begin{array}{lllll}\text { Stratagem. . . . . . . . . . . . } & .10 & .15 & .25 & .40\end{array}$

$\begin{array}{lllll}\text { Pride of Market. . . . . . . } & .10 & .15 & .25 & .40\end{array}$

Heroine........... $\quad .10 \quad .15 \quad .25 \quad .40$

Telephone.......... $\quad .10 \quad .15 \quad .25 \quad .40$

$\begin{array}{lllll}\text { Duke of Albany. . . . . . . } & .10 & .15 & .25 & .40\end{array}$

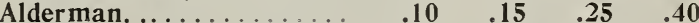

$\begin{array}{lllll}\text { Duchess.............. } \quad .10 & .20 & .30 & .45\end{array}$

$\begin{array}{lllll}\text { Boston Unrivaled. } \ldots \ldots \ldots & .10 & .15 & .25 & .40\end{array}$

Admiral Dewey.......... $\quad .10 \quad .20 \quad .30 \quad .45$

$\begin{array}{lllll}\text { Sutton's Peerless ......... } & .10 & .15 & .25 & .40\end{array}$

$\begin{array}{lllll}\text { Telegraph.............. } & .10 & .15 & .25 & .40\end{array}$

$\begin{array}{lllll}\text { L. I. Mammoth. ........ } & .10 & .15 & .25 & .40\end{array}$

Champ. of England. .... $\quad .10 \quad .15 \quad .25 \quad .40$

$\begin{array}{lllll}\text { White Marrowfat. ......... } & .10 & .15 & .20 & .35\end{array}$

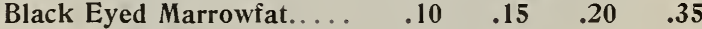

Melting Sugar........... $\quad .10 \quad \begin{array}{llll}.25 & .35 & .50\end{array}$

Imp. Sugar Marrow. ..... $\quad .10 \quad .15 \quad .25 \quad .40$

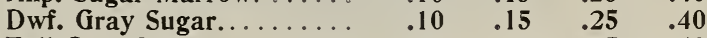

Tall Gray Sugar. ........ $\quad .10 \quad .15 \quad .25 \quad .40$

Peck and Bushel Prices vary. Write for Them. 


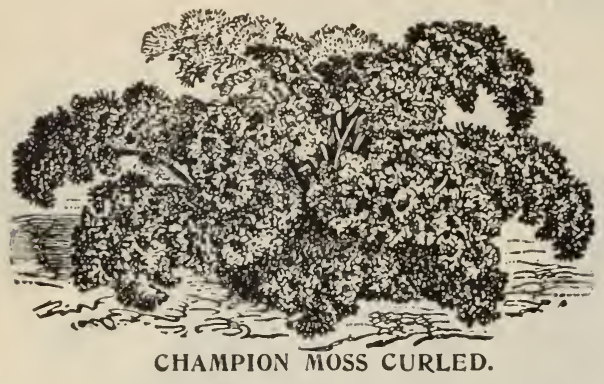

\section{PARSNIP}

Hollow Crown. Roots long, white, smooth, tender, sugary and of most excellent flavor. Very hardy, and will keep through winter without protection. Pkt., 5c.; 0z., 10c.; 2 oz., 15c.; $\frac{1}{4}$ lb., 20c.; lb.s, 50c.

Guernsey. Roots comparatively short, with a very smooth, clean skin. Pkt., 5c.; 0z., 10c.; 2 oz., 15c.; 妾 lb., 20c.; lb., 50c.

Market Garden. The best sort for heavy, black soils. In the vicinity of Chicago, where the soil is exceedingly rich, this is the variety needed, as it makes a fine shaped root which does not grow too long. Pkt., 5c.; oz., 10c.; 1 lb., 20c.; lb., 50c.

\section{PEPPERS}

Sweet Mountain. Plants very vigorous and productive, growing upright, with moderately large leaves. Fruit very large, long, often eight inches or more in length, by two in diameter. Pkt., 5c.; oz., 20c.; $\frac{1}{4} \mathbf{l b . ,} 50$ c.

Large Bell or Bull Nose. A very large sort of inverted bell shape, suitable for filling or for a mixed pickle. Flesh thick, hard and less pungent than most other sorts. Pkt., 5c.; oz., 20c.; $\frac{1}{4}$ lb., 50c.

Procopp's Giant. Very large, usually 8 to 9 inches long and 3 inches thick. Brilliant scarlet color, flesh thick, of pleasant flavor. Pkt., 5c.; oz., 20c.; $\frac{1}{4}$ lb., 50c.

Ruby King. An improved American sort, reaching the largest size, yet retaining the symmetrical shape of the smaller sorts. Pkt., 5c.; oz., 20c.; $\frac{1}{4}$ lb., 50c.

Large Squash. Fruit large, flat, tomato shaped, more or less ribbed, skin smooth and glossy. Pkt., 5c.; oz., 20c.; $\frac{1}{4}$ lb., 50c.

Golden Upright. The fruits are large and of a beautiful rich golden yellow, tinged with blush red. The peppers are mild and as pleasant to the taste as Ruby King. Pkt., 5c.; oz., 20c.; $\frac{1}{4}$ lb., 50c.

Red Cherry. Plant tall, bearing a profusion of bright red, round fruit

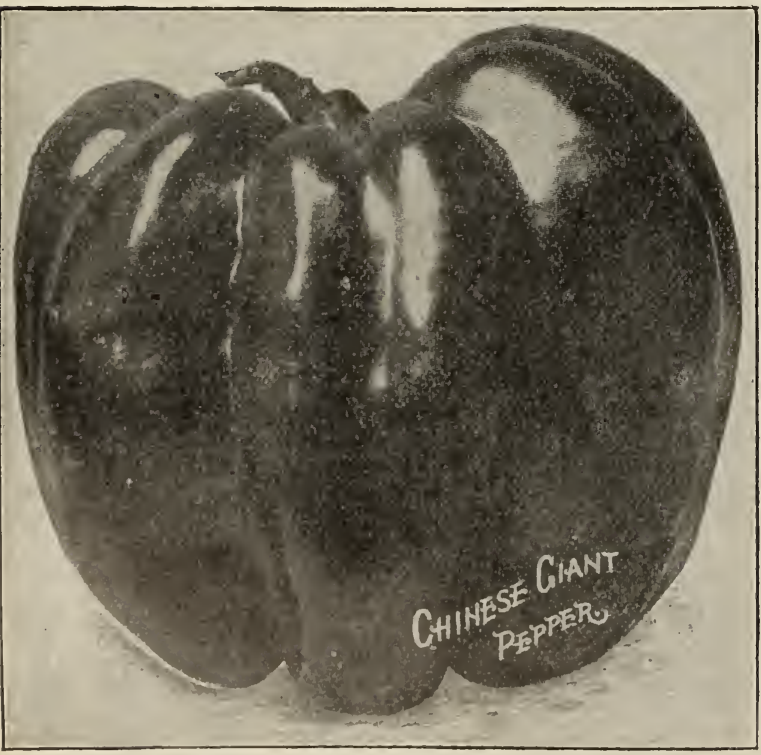
which is very pungent when ripe. The plant is very handsome and an ornament to the garden. Pkt., 10c.; oz., 30c.

Chinese Giant Pepper. Without doubt one of the very best and largest Mango Peppers ever introduced. Its mammoth size, splendid shape, beautiful, rich, glossy-red flesh and mild flavor, all lead us to speak of it in words of commendation. Pkt., 10c.; 0z., 35c.; $\frac{1}{4}$ lb., $\$ 1.00$.

Golden Dawn. In shape it resembles the popular Bell or Bull Nose pepper. It is of a most beautiful golden yellow color, making a very handsome appearance, both in growth and upon the table. Pkt., 5c.; oz., 20c.; 11 lb., 50 c.

Red Chili. Used in the manufacture of pepper sauce. Pkt., 10c.; 0z., 30c.

Long Red Cayenne. A long, slim, pointed pod, and when ripe, of a bright red color. Extremely strong and pungent. Pkt., 10c.; 0z., 30c.

Tabasco. Of tall, bush-like growth, three to four feet in height, producing an immense number of small, slender, fiery fruits one inch in length and vivid scarlet in coloring. This is the true variety, from which the famous Tabasco Sauce is made. Per pkt., 10c.; oz., 45c.; $\frac{1}{4}$ lb., $\$ 1.25$. 


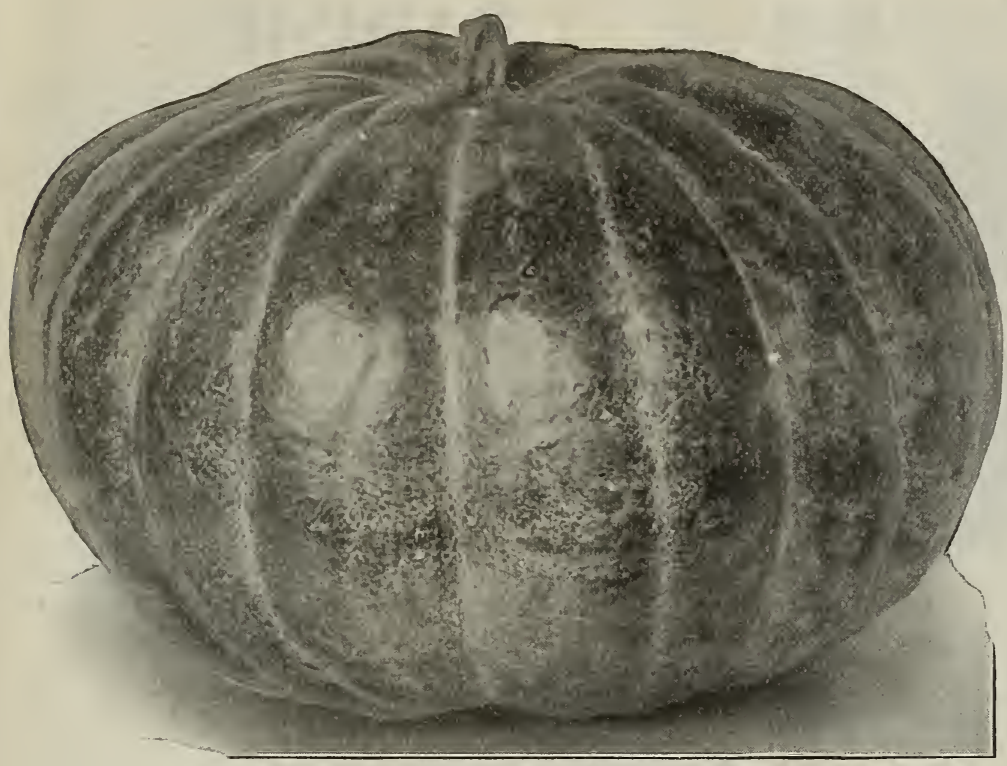

PUMPKIN

Cheese or Kentucky Field. One of the best for table use, and very productive. Shape flat; flesh yellow, thick, and tender.

Pkt., 5c.; 0z., 10c.; $\frac{1}{4}$ lb., 15c.; lb., 40c.

Golden Oblong. A productive variety, oblong in shape. Skin golden orange, flesh yellow, dry, and sweet; excellent.

Pkt., 5c.; oz. 10c.; lb., 60c.

Large Tours, or Mammoth. Grows to an immense size, often weighing over $100 \mathrm{lbs}$.

Pkt., 5c.; 0z., 10c.; 1 lb., 30c.;

lb., $\$ 1.00$.

Sugar or Pie. A rather small, but handsome variety. Shape, round; skin deep orange colored; flesh fine grained, sweet-flavored; superior for pies.

Pkt., 5c.; oz., 10c.; $\frac{1}{4}$ lb., 20c.; lb., $60 \mathrm{c}$.

PUMPKIN CHEESE OR KENTUCKY FIELD

Winter Queen. This is an improvement of the old, well liked, sugar pumpkin. Its size is uniformly about nine to ten inches in diameter. In color, a beautiful deep orange yellow, with a very close netting, almost as russeted as a potato.

Pkt., 5c.; 0z., 10c.; $\frac{1}{4}$ lb., 25c.; lb., 75c.

Connecticut Field. The hardiest of all Pumpkins; cultivated mainly for stock-feeding, producing enormous crops.

Pkt., 5c.; 0z., 10c.; $\frac{1}{4}$ lb., 15c.; lb., 40c.

Cushaw, or Crookneck. A favorite sort of excellent quality.

Pkt., 5c.; 0z., 10c.; $\frac{1}{4}$ lb., 25c.; lb., 80c.

Calhoun. Round, flattened, skin brown; flesh salmon-yellow, thick and fine-grained. Pkt., 5c.; oz,. 10c.; lb., 60c.

Tennessee Sweet Potato. Hardy, productive, sweet and delicious, and one of the best for cooking purposes ever introduced. Pkt., 5c.; 0z., 10c.; lb., \$1.00.

Mammoth Potiron. The flesh and skin are of a bright golden yellow color. 'Flesh, fine grained and of excellent quality. This enormous variety has been grown to weigh 200 pounds. Pkt., 5c.; oz., 15c.; lb., \$1.50.

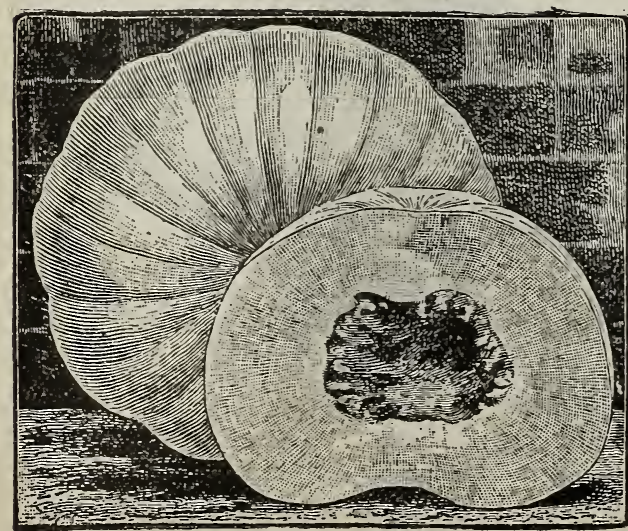

CALHOUN PUMPKIN

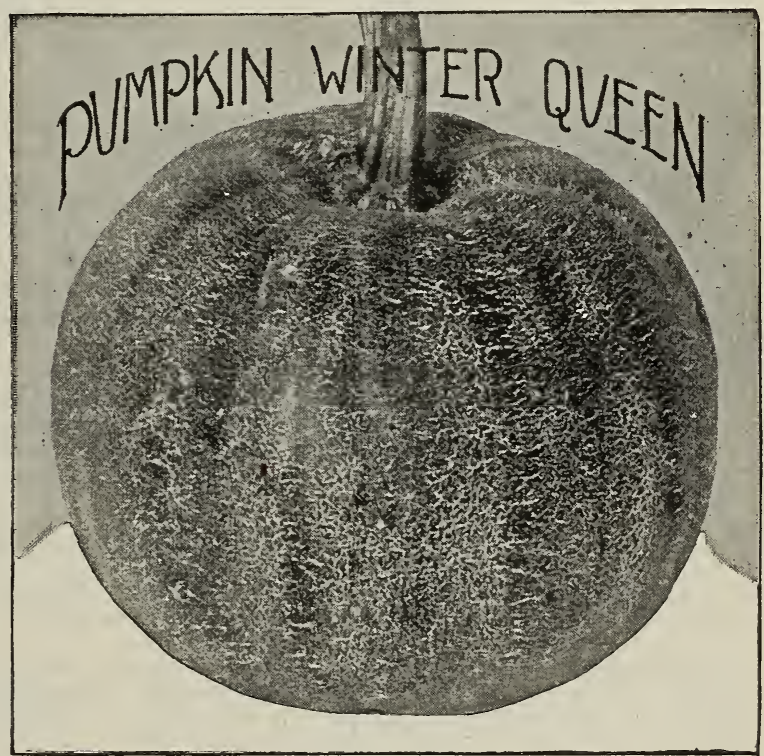

RHUBARB

(Pie Plant)

Culture. Rhubarb succeeds best in deep, somewhat retentive soil. The richer its condition and the deeper it is stirred the better. Sow in drills an inch deep, and thin out the plants to six inches apart. In the fall transplant the young plants into very highly manured and deeply stirred soil, setting them four to six feet apart each way, and give a dressing of coarse manure every spring. The stalks should not be plucked until the second year, and the plant never allowed to exhaust itself by running to seed. Our seed is saved from selected plants of the Linnæus, Victoria, Giant, and other improved sorts, but like the seeds of fruit trees, rhubarb seed cannot be relied upon to reproduce the same varieties.

Rhubarb Seed. Pkt., 5c.; 0z., 15c.; 2 oz., 25c.; $\frac{1}{4}$ lb., 40c.; lb., $\$ 1.25$.

Rhubarb Roots. By expreśs, not prepaid, 20c. each, \$1.50 per doz. By mail, prepaid, 25c. each, $\$ 2.00$ per doz.

Prices on large lots of Rhubarb Roots on application. 


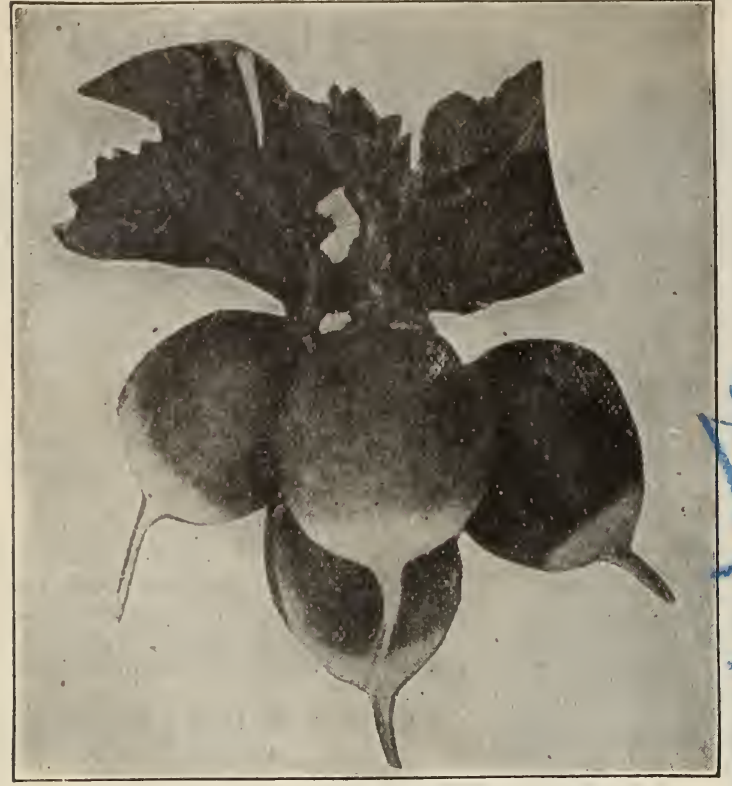

SCARLET TURNIP WHITE TIPPED RADISH

\section{RADISH}

Leonard's Three Leaf Radish. So named on account of its extreme earliness and the fact that when there are three leaves formed besides the seed leaf it is large enough to eat. It is an improved form of the well known Searlet Olive. Flesh is very crisp, tender and white, while the skin is a very bright scarlet. Pkt., 5c.; oz., 10c.; $\frac{1}{4}$ lb., 20c.; lb., 70c.

Non Plus Ultra. 'This is one of the finest forcing radishes. The roots are round, with a deep scarlet colored skin the flesh white, very crisp and tender. Pkt., 5c.; oz. 10c. $\frac{1}{4}$ lb., 20c.; 1b., 70c.

Olire Shaped Bright Red Leafless Forcing. The extra early forcing radishes latcly introduced are remarkable for the small size of their leaves. They develop their roots in so short a time that the latter are practically in adrance of the leaves. Pkt., 5c.; 0z., 10c.; \& 1b., 20c.; 16., 70c.

Rosy Gem. One of the very earliest in cultivation. Shape a perfect globe. Deep scarlet top, blending into pure white at bottom. Pkt., 5c.; oz., 10c.; 1 lb., 20c.; lb., 70c.

Early Scarlet Turnip. The standard early turnip radish. Fine flavored and mild. Pkt., 5c.; 0z., 10c.; 1 lb., 20c., lb., 50c.

Early Carmine. An extra early variety of turnip shaped radish. It is very mild and crisp. The flesh is white, the color is carmine, and the radish looks bright, dxen when wilted. 'This is, therefore, very salable on the market, even on the hottest days, when other radishes look dull and dry. Pkt., 5c.; 0z., 10c.; $\frac{1}{4}$ lb., 15c.; lb., 60c. Scarlet Turnip, White Tipped. One of the handsomest of the turnip radishes and a great favorite in many large markets for early planting outdoors. It is but little later than the White Tipped Forcing, and will give entire satisfaction where extreme earliness is not the primary object. Roots slightly flattened on the under side, color very deep scarlet with a white tip; flesh white and of the best quality. Pkt., 5c.; oz., 10c.; $\frac{1}{4}$ 1b., 15c.; lb., 50c.

Scarlet Olive. Very tender and a beautiful color. Early. Pkt., 5c.; oz., 10c.; $\frac{1}{4}$ lb., 15c.; lb., 50c.

Early Scarlet Globe. A desirable sort for hotbed forcing and outdoors, very early; flavor mild; crisp, juicy and tender; top small; will stand heat without becoming pithy. One of the best selling and most attractive radishes on account of its bright scarlet color and handsome shape; is ready in 28 days. Pkt., 5c.; $0 z ., 10 c . ; \frac{1}{4}$ lb., 20c.; lb., 60c. New Deep Scarlet Turnip. This is a very bright colored Scarlet Turnip radish, very early and short leaf, well adapted to forcing under glass. Matures in fourteen to twenty-one days, and its appearance will sell it in any market.

Pkt., 5c.; oz., 10c.; $\frac{1}{4}$ lb., 15c.; lb., 50c.

Early White Turnip Rooted. A little flatter than the Scarlet Turnip, and pure white in color.

Half Long Deep Scarlet. A variety half the length of Long Scarlet and of same form. Matures in twenty days.

French Breakfast. Olive shaped, scarlet, with white tip; crisp and tender. Very early. A general favorite.

Large White Summer Turnip. A very large turnip shaped variety; white, very crisp and mild.

Large Yellow Summer Turnip. Like the above, except in color.

Gray Summer Turnip. Popular for midsummer planting.

Early White, Olive Shaped. Like Scarlet Olive Shaped, except that the roots are clear white and a little longer.

White Strasburg, or Summer Hospital. Large, showy, half long, white sort. Grows with great rapidity, sometimes producing a crop in six weeks. It will keep in eatable condition two weeks before going into seed. Best summer radish grown.

Giant Stuttgart. A summer variety. Grows to an immense size. White flesh, very crisp and tender. Of good flavor, and a good keeper.

Triumph Scarlet Striped Forcing. 'The roots are the sliape of Prussian Globe but larger and are creamy white, beautifully marked with spots and dashes of carnine. The tops are small and the roots mature as early as any variety in cultivation. Desirable on account of its distinct beauty, earliness and good quality. Pkt. 5c.; 0z., 10c.; 2 oz., 15c.; $\frac{1}{4}$ lb., 25c.; lb., 85c.

Golden Globe. This variety is of quick growtlı, affording crisp and tender radishes even in the hottest climate and is extensively grown in the south. Root uniformly globe shape, with skin golden yellow in color. Pkt., 5c.; oz., 10c.; 2 oz., 15c.; + lb., 20c.; 1b., 60c.

Where not otherwise priced, all Radishes are. Pkt. 5c; oz., 10c.; 1 lb., 15c.; lb., 60c.; postpaid.

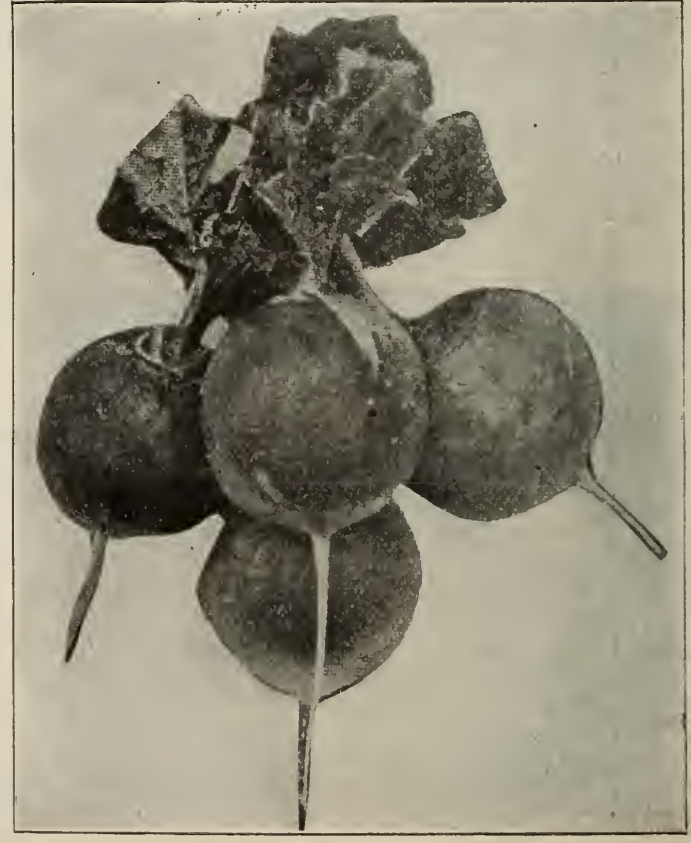

SCARLET GLOBE RADISH 


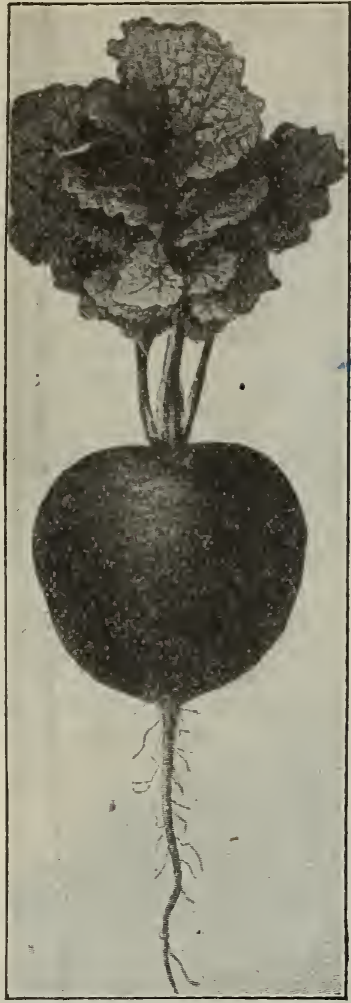

CRIMSON GIANT RADISH

Long Brightest Scarlet, White Tipped. This is the brightest and handsomest colored scarlet radish known, and a decided improvement in earliness and color over other varieties of this class. It makes roots fit for use in about twenty-five days from time of planting.

Chartier. Decidedly distinct in appearance. The color at the top being crimson, running into pink about the middle, and from thence downward it is a pure waxy white.

Early Long Scarlet, Short Top. This bright scarlet, small topped sort is about six inclies long, is uniformly straight, smooth, brittle and crisp, and is a standard and excellent sort for private gardens or market use. Pkt.; 5c.; oz., 10c.; 2 oz., 15c.; $\frac{1}{4}$ lb., 20c.; lb., 50c.

The Cincinnati Market. The tops of this new radish are very small and may stand much closer in the rows than Wood's Early Frame or Long Scarlet, without danger of running to seed. They grow straight and smooth, and from six to seven inches long.

Crimson Giant Turnip. A variety extraordinary in that, while growing to an unusually large size, it is always tender, crisp and of mild flavor. It remains in perfect condition a remarkably long time, and unlike other forcing varieties, does not become pithy even when twice their size in diameter. Root turnip shaped; color a beautiful crimson-carmine; flesh firm, crisp and tender. While very desirable as a second early forcing variety, we specially recommend it for outdoor planting.

White Icicle. This handsome white variety is becoming very popular. It is similar to White Vienna but is not so long, is earlier and has a shorter leaf. We recommend it as a profitable, early variety where a long white sort is desired. It is likely to sell well on all markets where the Strasburg is a favorite Oz., 10c.; lb., 50c.; 10 lbs., $\$ 4.50$.

Munich. This is an exI pellent summer variety, maturing between the Strásburg and Stuttgart. In form it resembles the Strasburg, and gardeners will find it a good sort to follow that variety.

Wood's Early Frame. Shorter and thicker than the Long Scarlet Short Top, one of the very best sorts for first crop out of doors.

Long White Vienna, or Lady Finger. A very excellent white variety with long, very smooth white roots, which are crisp and tender. It comes into use shortly after Wood's Frame and is one of the most desirable of the white summer sorts.

Scarlet China. Roots cylindrical; or largest at the bottom, tapering abruptly to a small tap. Skin very smooth and of a bright rose color: flesh firm, crisp, tender and quite pungent.

Round Black Spanish. Roots round, sometimes topshaped, three or four inches in diameter; skin black, flesh white, very compact and highly flavored. An excellent sort for winter, as the roots keep a long time.

Long Black Spanish. One of the latest as well as hardiest of the radishes; an excellent sort for winter use.

California Mammoth. First introduced into this country by the Chinese in California. It is pure white, about one foot long and two or three inches through, tapering regularly to the tip. The flesh is tender and crisp, keeping well through the winter. Pkt. 5c.; oz. 10c.; 2 oz, 15c.; $\frac{1}{4}$ lb. 25c.; lb. 75c.

Celestiaf.y A comparatively new variety which is popuMr where er known. The root is long, cylindrical, with beautiful white skin and flesh, so white as to attract attention, even among the other white varieties. The flesh is very tender and of excellent quality. Pkt. 5c.; oz. 10c.; $2 \mathbf{o z}$. 15c.; $\frac{1}{4}$ lb. 25c.; lb. 75c.

Where not otherwise priced all radishes are, Pkt. 5c.; oz. 10c.; $\frac{1}{4}$ lb. 15c.; lb. 60c., post paid.

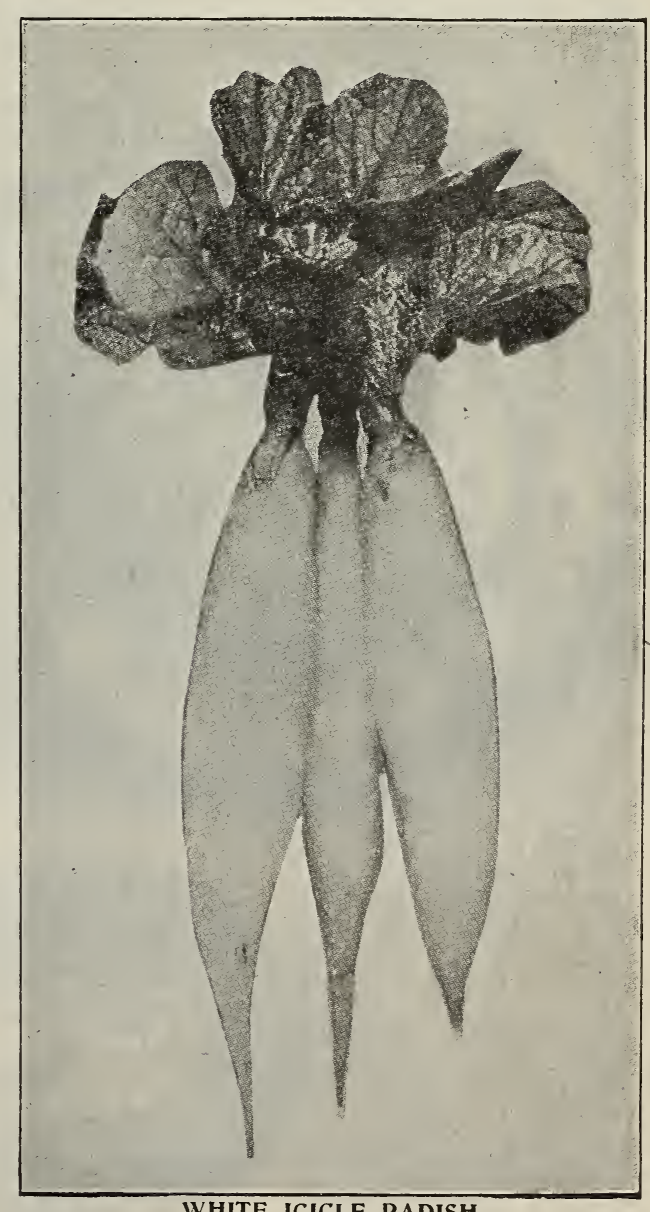

WHITE ICICLE RADISH 


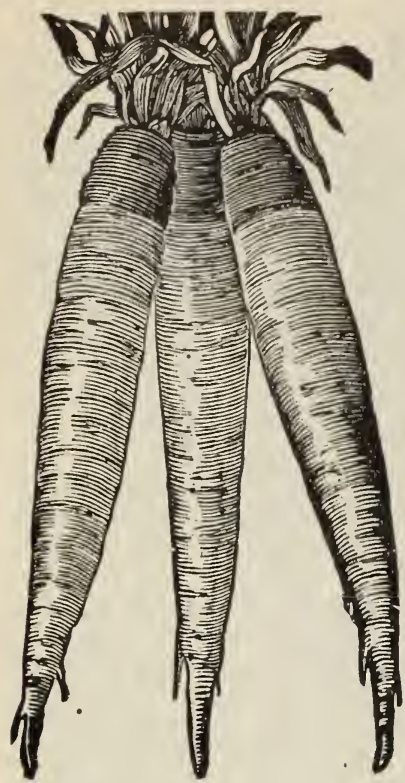

\section{SALSIFY \\ (VEGETABLE OYSTER.)}

The long white tapering root of salsify resembles a small parsnip, and when cooked is a good substitute for oysters, having a very similar flavor.

Large White. The common variety; roots medium sized, smooth; flesh white. Pkt., 5c.; oz., 10c.; 2 oz., 20c.; $\frac{1}{4}$ lb., 30c.; 1b., \$1.00.

Mammoth Sandwich Island. This is in every way superior to the Large White, being larger, stronger growing and less liable to branch. Invaluable to market gardeners. Pkt., 5c.; oz., 15c.; 2 oz., 25c.; $\frac{1}{4}$ lb., 40c.; lb., $\$ 1.50$.

\section{SPINACH}

Spinach is very hardy, extremely wholesome and palatable, and makes a delicious dish of greens, retaining its bright green color after cooking.

Victoria. An excellent sort, which forms a very large, exceedingly thick, dark green leaf, somewhat curled in the center. Pkt., 5c.; oz., 10c.; 2 oz., 15c.; $\frac{1}{1}$ lb., 20c.; ib., $40 \mathrm{c}$.

Savoy Leaved. The earliest variety and one of the best to plant in autumn for early spring use. Plant of upright growth, with narrow, pointed leaves which are curled like those of Savoy cabbage. Pkt., 5c.; 0z., 10c.; 2 0z., 15c.; $\frac{1}{4} 1$ lb., 20c. ; lb., $40 \mathrm{c}$.

Round Summer Broad Leaved. This variety is generally preferred in the North for early spring sowing, and is the most popular with our market gardeners. Pkt., 5c.; oz., 10c.; 2 oz., 15c.; $\frac{1}{4} 1 \mathrm{~b} ., 20 \mathrm{c} . ; 1 \mathrm{~b} ., 35 \mathrm{c}$.

Broad Flanders. One of the most vigorous and strong growing varieties. The leaves are nearly round, uniformly bright green, quite thick and slightly crimped SANDWICH ISLAND SALSIFY. in the center. Pkt., 5c.; oz., 10c.; 2 oz., 15c.; $\frac{1}{4}$ lb., 20c.; lb. 40c.

Improved Thick Leaved. A variety which grows very rapidly, forming a cluster of large, very thick, slightly wrinkled leaves, recommended for market gardeners. Pkt., 5c.; oz., 10c. ; 2 oz., 15c.; 1 lb., 20c.; lb., 40c.

Long Standing. An improved, round seeded strain of excellent merit, having all the good qualities of other sorts and continuing in condition for use much longer. Pkt., 5c.; oz., 10c.; 2 oz., 15c.; 1 lb., 20c.; lb., 40c.

Prickly Winter. A very hardy variety, and will withstand the severest weather with only a slight protection of leaves or straw Pkt., 5c.; oz., 10c.; 2 oz., 15c.; $\frac{1}{4}$ lb., 20c.; 1b., 35c.

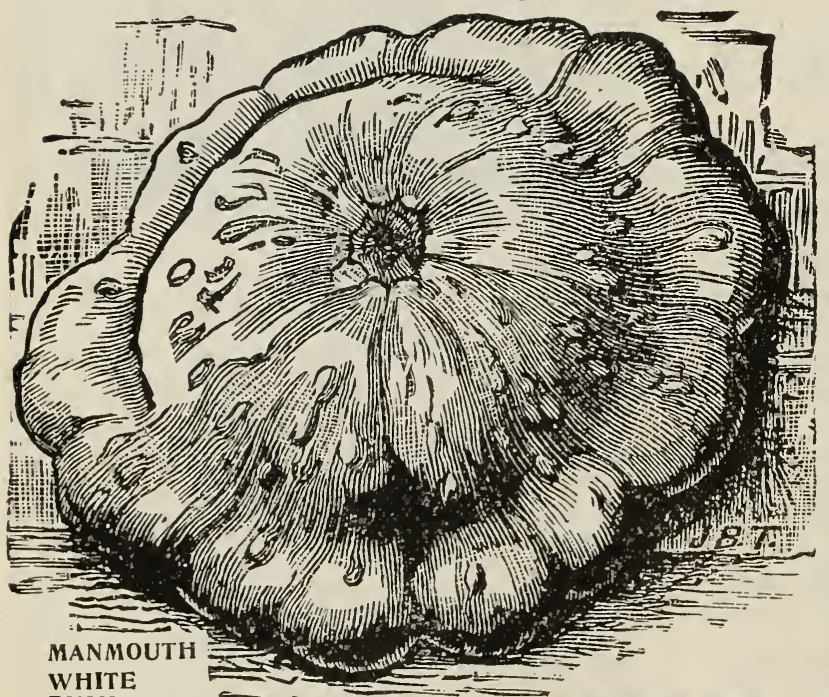

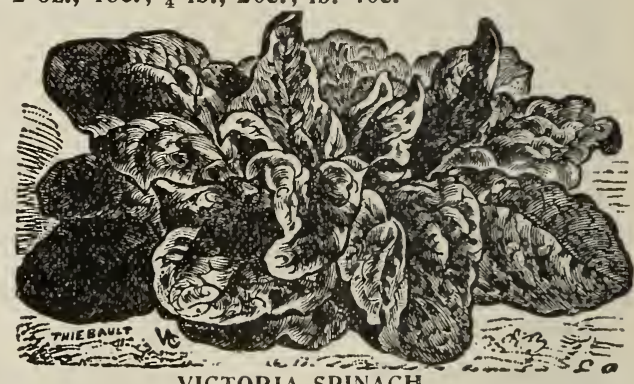

VICTORIA SPINACH.

\section{SOUASH}

Mammoth White Bush. This variety is a selection made from the Early White Bush; the improvement consists in size of the squashes it produces.

Early White Bush or Patty=Pan, is earlier than any other variety of dwarf habit and very productive. Summer Squashes should always be used when young and tender, which can be determined by an impression of the nail.

Early Yellow Bush Scallop or Golden Custard. A very early, flat, scalloped variety of lirgest size; color, yellow; flesh pale yellow and well lavored.

Fordhook. The vines are of strong, vigorous growth and wonderfully productive. Fruits oblong in form, eight to ten inches in length, slightly ridged smooth, thin, yellowish skin; flesh very thick and of a light straw yellow.

BUSH.

Giant $\dot{C}_{\text {rook}}=$ Neck. This strain is a great improvement on the old variety of Crookneck. It is

larger and better in every Way. Squash. In our Straightneck the bad feature of the crook has been overcome, and by continued selection the size has been increased more uniformly in shape, improved quality.

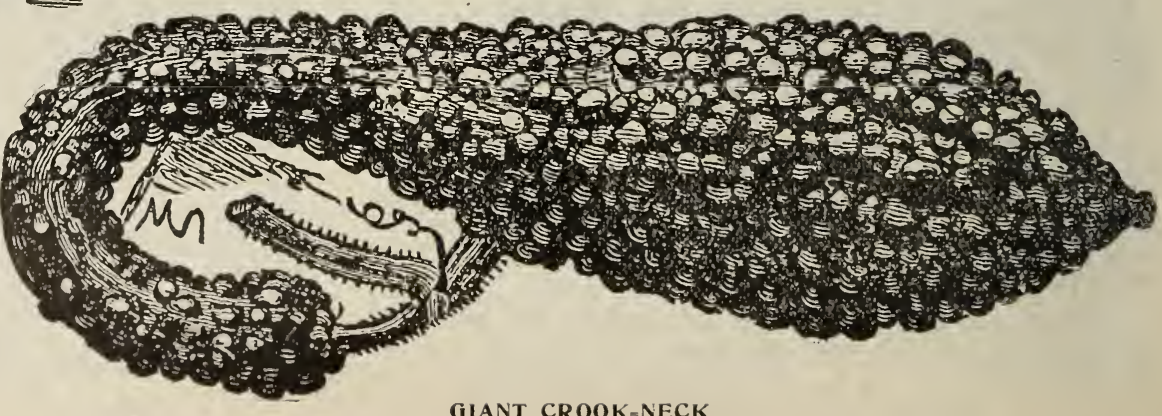

GIANT CROOK=NECK 
Golden Hubbard. This is a very distinct sort of a shape and general character of the Hubbard, but a little smaller; of rich orange red color, instead of the dark olive green.

Boston Mar= row. Is the favorite Winter Squash of the Eastern States: it is of fine $\mathrm{fla}$ vor, and a good keeper.

Orange $\mathrm{Mar}=$ row. This is the earliest of all Winter varie ties. Its distinctive feature

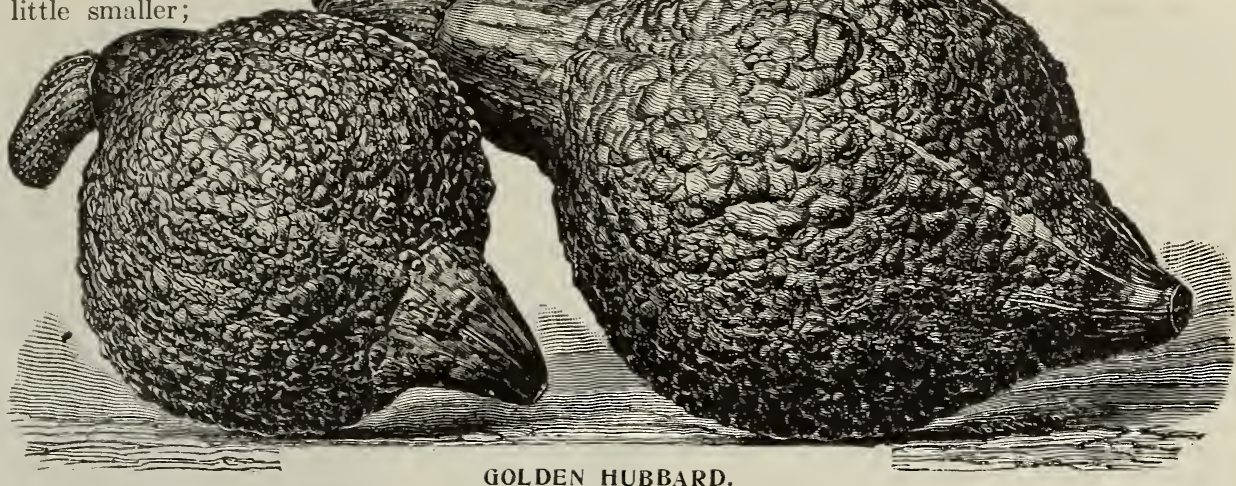

and the one which will give it the greatest and most wide-spread popularity, is its earliness; it is at least ten days earlier than any other long keeping sort. It grows as long as the Hubbard, and is of as good quality.

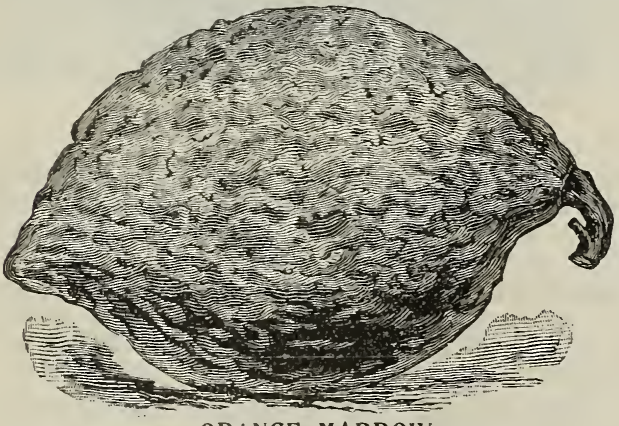

ORANGE MARROW

Delicious. This is one of the best Winter varieties. Its color is almost uniform of a green shade, with occasionally a blue specimen, it being just about as pure in this respect as was the original Hubbard. In size, it also closely follows the original Hubbard, which weighed between 5 and 10 pounds. In thickness of flesh it surpasses nearly every variety, the color being a dark orange.
Hard Shelled Marrow. The best sort for canning and drying. The fruit is very large, oval, of deep orange-red color and though quite smooth, has as hard a shell as the Hubbard. The flesh is very thick, of rich orange-red color without a tinge of green.

\section{Squash Price List.}

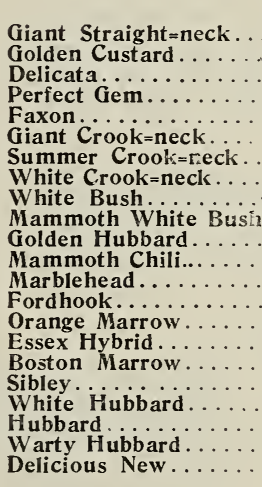

\begin{tabular}{r} 
Pkt. \\
$\$ 0.05$ \\
\hline .05 \\
.05 \\
.05 \\
.05 \\
.05 \\
.05 \\
.05 \\
\hline .05 \\
\hline .05 \\
\hline .05 \\
.10 \\
.05 \\
.05 \\
.05 \\
.05 \\
.05 \\
.05 \\
.05 \\
.05 \\
.05
\end{tabular}

\begin{tabular}{rr} 
Oz. & \multicolumn{1}{c}{ Lb. } \\
$\$ 0.10$ & $\$ 0.65$ \\
.10 & .65 \\
.15 & 1.00 \\
.15 & 1.00 \\
.10 & .65 \\
.10 & .65 \\
.10 & .65 \\
.15 & 1.00 \\
.10 & .65 \\
.10 & .75 \\
.15 & .75 \\
.25 & 1.25 \\
.15 & 1.00 \\
.10 & .75 \\
.10 & .60 \\
.15 & 1.00 \\
.10 & .60 \\
.15 & 1.00 \\
.15 & 1.00 \\
.10 & .80 \\
.10 & 1.00 \\
.15 & 1.00
\end{tabular}

The Hubbard cannot be too highly extolled as a Winter Squash; it boils smooth and dry, is of very rich quality, and keeps as solid as a rock. It is more popular with private growers than any other variety.

Leonard's Warty Hubbard. This is the best strain of Hubbard Squash. By its rough, hard warty shell and its dark olive green color, it can be distinguished from any other strain either in the field or on the market. It was introduced by us in 1894, and since that time under different names at different places, it has been given out to all who have called for the best stock of Hubbard Squash. We have maintained its purity and offer headquarters' seed. For keeping over winter this strain is superior to all others. It is the best shipping variety and the best seller. 


\section{TOMАТО}

Livingston's Coreless. In describing this grand new variety, the originators say: We have been growing this variety for a number of years, and by careful selection have so fixed the type, that in a plot containing about 1,000 plants, grown on wire trellis in 1907, not a single plant showed "off color," and very few any objectionable variation as to shape

The two distinctive features which stand out most prominently are, great depth from stem to blossom; and the depression at the stem has been almost entirely eliminated.

It has less indenture than any other of the red Varieties It has no corrugations at stem end, and absolutely no green core; for these reasons it is a model variety for canning and catsup.

Livingston's Globe. Another new variety of exceptional merit It is of beautiful globe shape, with quite a percentage of elongated (stem to blossom) fruits, which permits of a greater number of slices being taken than from flat fruited sorts. Among the first to ripen, although of large size, very smooth, firm fleshed, few seeds, ripens evenly; color a beautiful glossy rose, tinged purple.

Quarter Century. A dwarf growing variety; fruit large, bright red in color. The upright habit of the vine permits close planting.

Spark's Earliana. This Tomato is not only remarkable for its earliness, but for its very large size, handsome shape and bright red color. Its solidity and fine quality are quite equal to the best medium and late sorts.

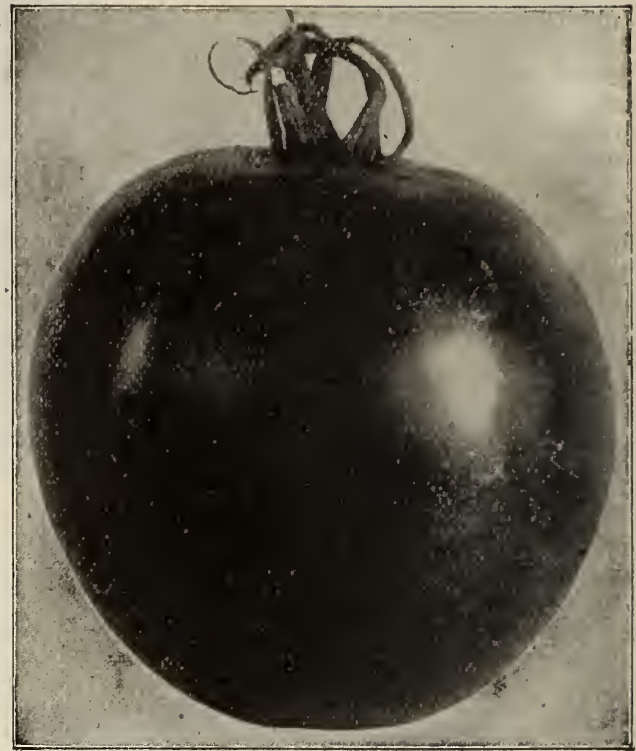

NEW CORELESS TOMATO.
Chalk's Early Jewel. The largest, smoothest and finest flavored extra early Tomato in cultivation! Within a week to ten days as early as the famous Spark's Earliana, it is a heavier cropper, with tomatoes of larger size and sweeter flavor.

Crine's June Pink. A fine new variety. It is highly recommended to gardeners whose trade demands the purplish pink sorts. It is the earliest of this class of tomatoes and fills the place in them that Earliana does in the bright red sorts.

Yellow Cherry. The small, yellow fruits, borne in clusters, average half an inch in diameter.

Red Cherry. Little fruits of a bright scarlet color.

Strawberry or Husk To mat o. Plants of low-spreading growth and immensely productive. The small yellow fruits are each enclosed in à husk.

$\mathrm{R}$ e d $\mathrm{P}$ e a $\mathrm{r}=$ Shaped. This is a leading favorite for preserves and also to make "tomato figs." The fruit is bright red, of true pear shape, and of rich distinct flavor.

Our specialty is the Market Garden Trade. Our stocks of Cabbage, Cauliflower, Onion, Celery, Radisl, etc., are grown and selected to meet the requirments of this critical class of buyers. Our prices are low, con= sidering the exceptional quality of our goods.

Superior stocks are necessary to the prosperity of the market planter. The inferior Article may be more attractive at the beginning, because it costs less, but the superior seed gives the more valuable product. You cannot afford to do without the best.
Dwarf Stone. As its name implies this is a dwarf variety bearing fruits similar to that popular canners sort, the Stone. The vine is upright and stocky, as much so as the Dwarf Champion.

Crimson Cushion. A large fruited variety; smooth on the top but inclined to curve at the ends making an indenture at the stem. Color a glossy crimson, tinged pink.

Our Tomato Seed is taken from selected fruits and is Superior in every way.

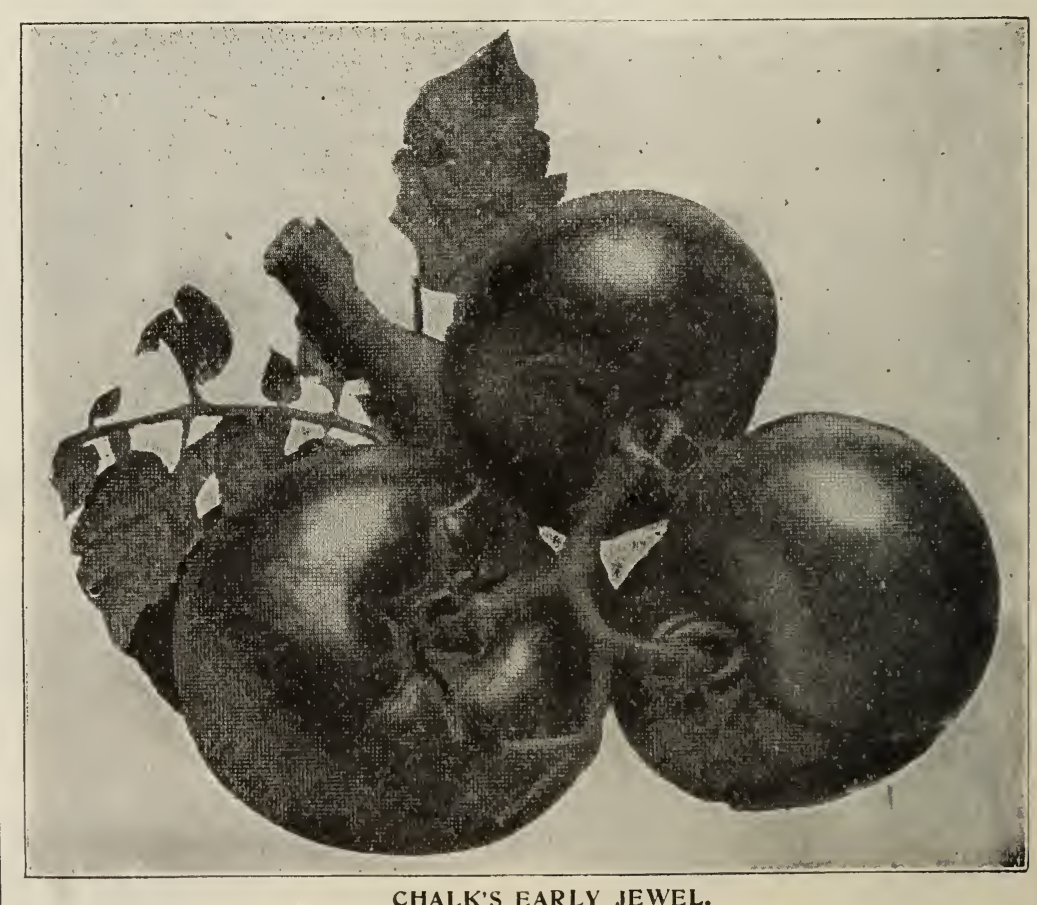

CHALK'S EARLY JEWEL. 


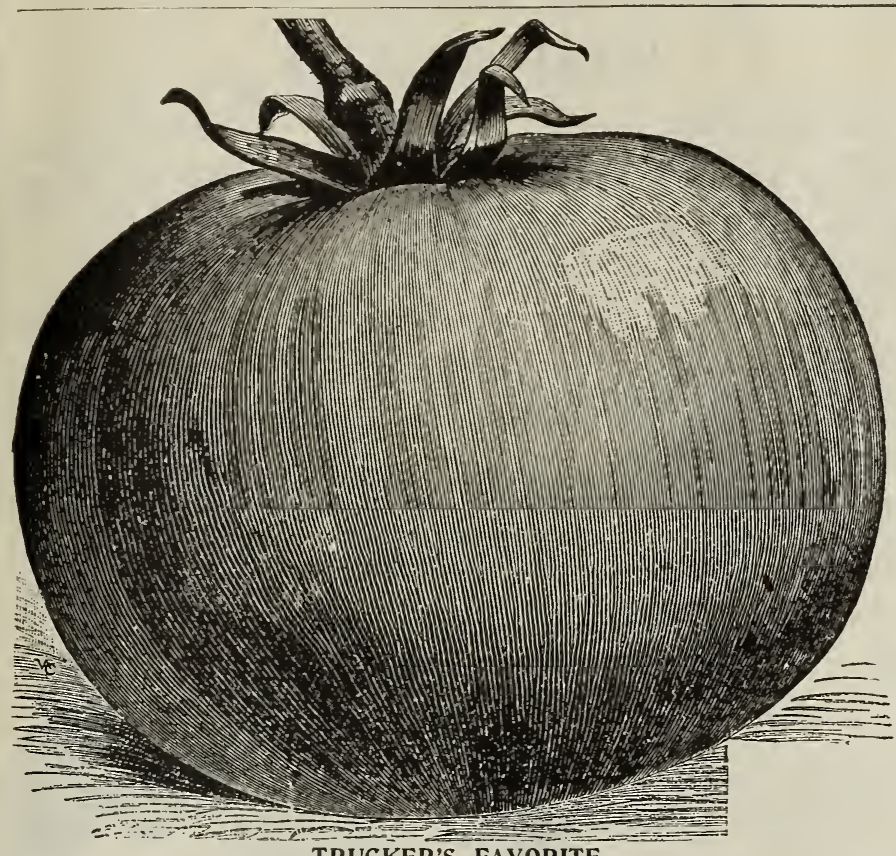

\section{TOMATO}

Trucker's Favorite. The finest large-fruited purple Tomato. Most regular in form and size; thick-meated and very solid. This is one of the largest smooth tomatoes grown. Of a beautiful purplish-red color.

Matchless. The best large-fruited bright red Tomato. Matchless is well worthy of its name; in beauty and symmetry of form it is indeed without a fault. The vines are of strong, vigorous growth, well filled with fruit. The fruits are entirely free from core, of a rich cardinal red color, and are not liable to crack from wet weather.

Success. The vines are of strong, vigorous growth with abundant foliage. The fruits, set in clusters. Color brightest scarlet; perfectly smooth; very meaty, of fine flavor.

Beauty. A decided favorite for either home market or shipping purposes, being early, hardy, a strong grower, productive, large size, always smooth, perfect in shape and excellent in quality. The color is very glossy crimson, with a tinge of purple.

Mikado, or Turner's Hybrid. One of the latest of the good market varieties. The vines are very distinct. Have a potato leaf appearance. In color this sort is like the Acme, fine, large, smooth fruits.

Stone. This variety has obtained great favor with canners, southern growers, and market gardeners everywhere. Its solidity and carrying qualities are remarkable. Its color is a desirable red; in shape, perfectly smooth, and thicker from stem to blossom end than most varieties, making it very handsome and salable.

Atlantic Prize. Small, irregular, bright red; extremely early.

Nolte's Earliest. Similar but not equal to Sparks' Earliana.

Acme. The well-known popular standard bright pink tomato.

Paragon. The well-known standard bright red tomato.

Livingston's Perfection. In our opinion identical with Paragon.

Livingston's Favorite. Bright red, smooth, of good size.

Livingston's Magnus. Large, late, purple; potato-leaf foliage.

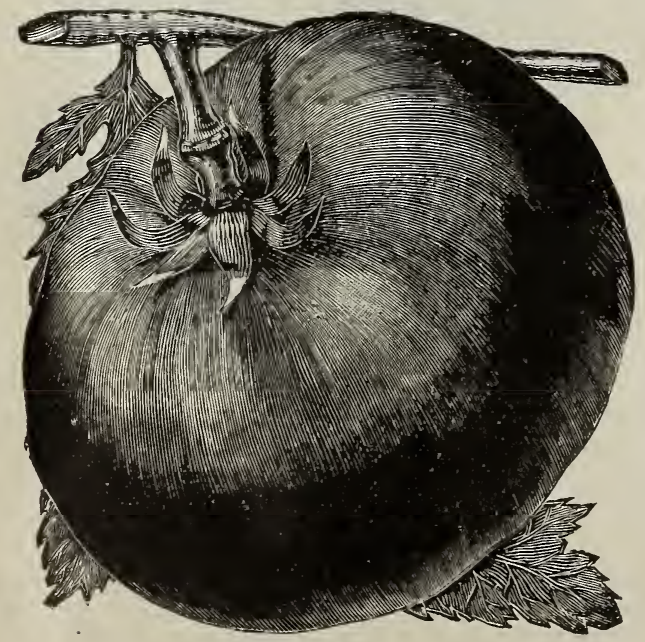

THE BEAUTY.
Ponderosa. This variety when conditions are favorable, grows to an immense size, and makes the heaviest fruit of any in the list.

Imperial. Large purple-fruited early.

Enormous. Extra large, solid, bright red.

Honor Bright. First white, then brilliant scarlet

Dwarf Aristocrat. Upright growth; bright red fruits.

Dwarf Champion. Deep purplish red; most popular dwarf.

Trophy. Very large, solid, and generally smooth; bright red.

Golden Queen. A first-class large, smooth, pure yellow tomato.

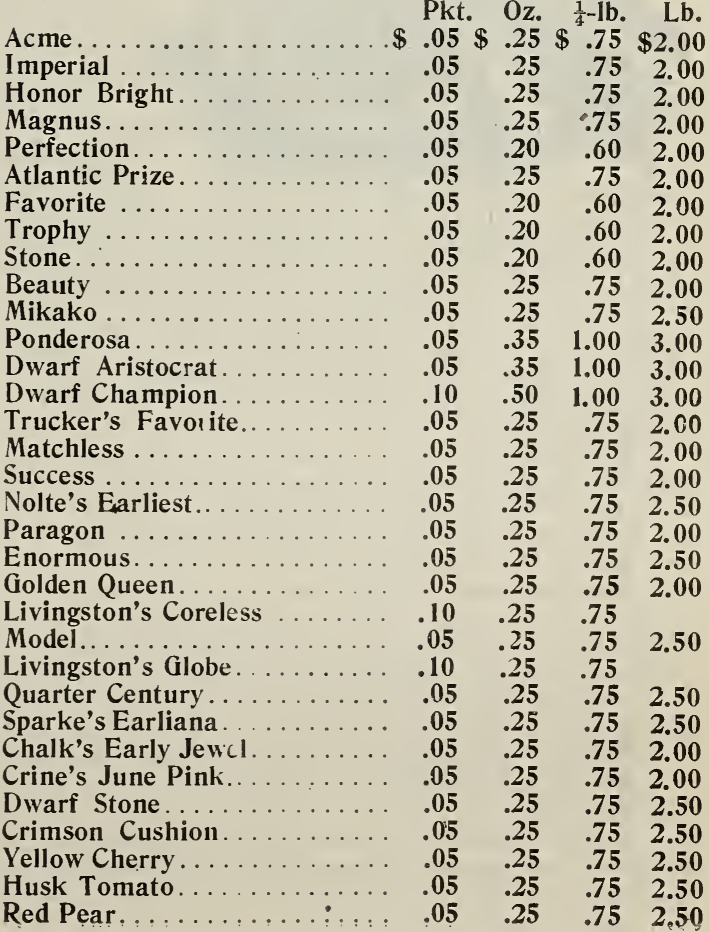




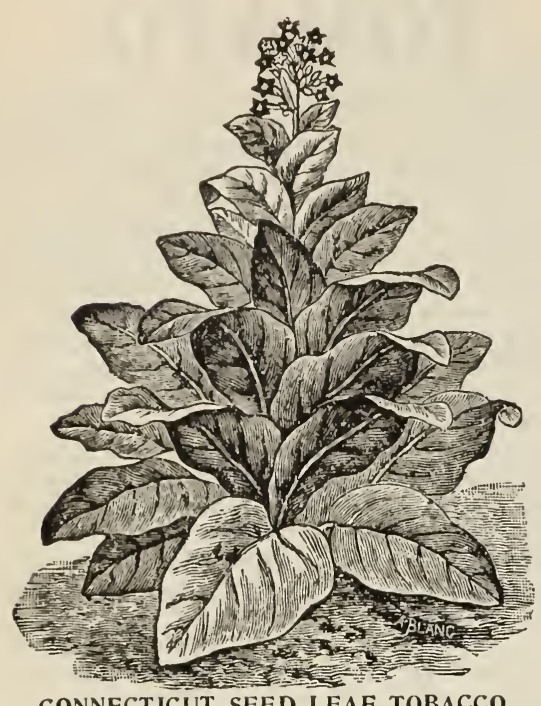

TOBACCO

Pennsylvania Seed Leaf. This is the variety mostly grown for cigars, and is of fine quality and excellent flavor. Pkt., 5c.; oz., 20c.; lb., \$2.00. Persian Rose. A fine brand for eigars. Sells well. Pkt., 5c.; oz. 20c. Yellow Pryor. A fine yellow sort, and succeeds well where others fail. Pkt., 5c.; 0z., 20c.; $15 ., \$ 2.00$.

Blue Pryor. 'This is the genuine articke and a good sort. Pkt., 5c.; oz., 20c.

General Grant. Very early, and a good yielder. Pkt., 5c.; oz., 20c.; lb., $\$ 2.00$

Connecticut Seed Leaf. The best sort for eigar wrappers. Try it.

Pkt.; 5c.; oz., 20c.; lb., $\$ 2.00$.

Havana. This is the genuine article, and is first-class. Pkt., 5c.; oz., 20c.; lb., $\$ 2.00$

Ohio. White leaved. A large yielcker. Pkt., 5c.; oz., 20c.; Ib., \$2.00,

\section{TURNIP}

(For Prices See Foot of Page.)

CONNECTICUT SEED LEAF TOBACCO.

Extra Early White Milan Turnip. The Purple Top Milan is/ one of the most popular turnips for spring sowing, but in this new: sort we have a splendid extra early turnip in which the extreme: earliness, small top and tap root of the Purple Top Milan is united: with clear white skin and flesh. It will undoubtedly find a welcome in our markets, as, in addition to the heavy crop assured by its adaptability for close planting, it will be found to be fit for use at least a week earlier than any other pure white variety in cultivation. Pkt. 5c.; oz. 10c.; $\frac{1}{4}$ lb., 20c.; 1b., 75c.

Pomeranean White Globe. This is one of the most productive kinds, and in good, rich soil roots will frequently grow to twelve pounds in weight. It is of perfect globe shape; skin white and smooth; leaves large and dark green.

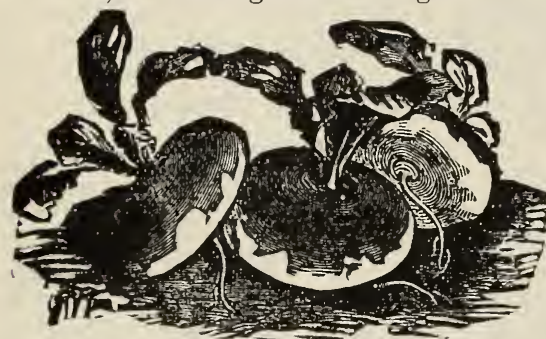

Purple Top White Globe. An early variety. Globe shaped; heavy cropper. In other respects similar to the Red Top Strap Leaf. A handsome looking bulb, and is rapidly taking the lead of all other varieties of early turnips for market garden purposes.

Extra Early Purple Top Milan. The earliest in cultivation, two weeks earlier than Purple Top Strap Leaf. The bulb is flat, of medium size, quite smooth with a purple top. Flesh white, hard and of finest quality. It is an extra good keeper. Pkt. 5c.; oz., 10c.; $\frac{1}{4} \mathrm{lb}$. 20c.; lb., 75c.

Cow Horn. This variety is pure white, except a little shade of green at the top, and is carrot-like in form, growing nearly half out of the ground, and slightly crooked. It is delicate and well flavored, of very rapid growth, and has obtained considerable favor as a market sort for

EXTRA EARLY PURPLE TOP MILAN. fall and early winter use.

Early Snowball. A perfectly globe shaped, white skinned turnip. It is exceedingly productive. The flesh is fine grained, firm and of very delicate flavor. It is one of the best keeping of the white fleshed sorts. Very early and particularly adapted for family or market use. We recommend it to market gardeners because its earliness and fine appearance make it a very profitable variety of turnip.

Early White Flat Dutch. An excellent garden variety. The best for spring sowing

White Egg. Belongs to the class of quick growing fall turnips, and for this purpose should be sown, in this latitude, between August 10 and 25. Its shape is nearly oval or egg, as its name would indicate.

Large White Norfolk. The standard variety for field culture for feeding stock. Very large size.

Sweet German. This variety is very popular in many sections, notably so in the New England states. It partakes largely of the nature of the rutabaga, and should be sown a month earlier than the flat turnips. The flesh

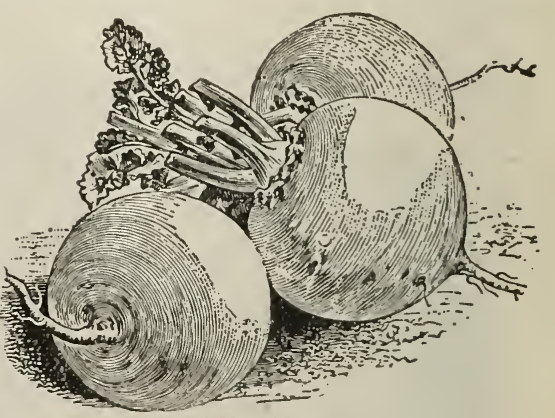

EARLY SNOWBALL.

is white, hard, firm and sweet; keeps nearly as well as the rutabaga. Highly recommended for winterand spring use. Seven Top. Cultivated extensively in the south for the tops, which are used for greens. It is very hardy and will grow all winter, but does not produce a good root, and is only recommended for the tops.

Purple Top Munich. 'The earliest variety after the Red Top Milan. Color white, with purplish white tops.

Purple Top Strap Leaf. Rapid grower and mild flavor, the most popular variety for early use, either for the table or stock.

Scarlet Kashmyr. A most distinct novelty; of such peculiar color that it has a striking resemblance to a large radish. "Unwarned judges would, no doubt, pronounce it one of those radishes so persistently complained of as tasting like turnips!" However, it is a turnip, and of most excellent flavor: of a deep, rich crimson above, shading to a soft crimson rose below.

Prices of all varieties of Turnip on this page, except where noted otherwise, are: Pkt., 3c.; 1=2 oz., 5c.; oz., 10c.; 1=4 lb., 15c.; lb., 50c., Post=paid. 


\section{TURNIP - Yellow Fleshed Sorts}

Yellow Aberdeen. Very hardy and productive, a good keeper; globe shaped Color pale yellow, with purple top. Very firm in texture, and closely resembling the Rutabagas in good keeping qualities. Good either for table or stock.

Large Amber Globe. One of the best varieties for a field crop for stock Flesh Yellow, fine grained and sweet: color of skin yellow; top green. Hardy, keeps well, a good cropper. Very popular in the south.

Yellow Stone. A very desirable sort. The roots are of medium size, uniformly globular and perfect in shape, smooth skinned and of pale yellow color. The flesh is crisp, tender and of fine quality.

Yellow Globe. Very similar to the Yellow Stone and a very attractive sort.

Orange Jelly, or Golden Ball. Undoubtedly among the most delicate and sweetest yellow fleshed turnips yet introduced. Not of a large size, but firm, hard and of most excellent flavor. Keeps well and is superior as a table variety. It is extensively used.

\section{RUTABAGA-Swedish Turnip}

\section{For Prices See Foot of Page.}

White Rutabaga. This variety is now very extensively cultivated, and preferred in many sections for its white flesh. It is very hardy and productive, keeps well until late in the spring, and is highly esteemed for its sweet delicate flavor.

Sweet German. A superior variety for table or stock. Flesh firm, sweet

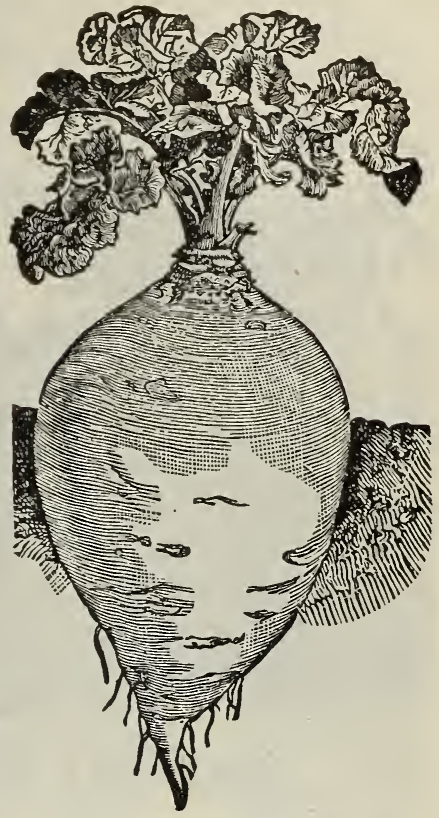

WHITE RUTABAGA. and juicy.

Laing's Improved. One of the earliest of the rutabagas. Forms a handsome bulb of good quality. Keeps well; good for table use.

Long White French. A very delicate flavored variety. An excellent keeper and fine for table.

Skirving's Purple Top. A very heavy cropper. One of the best for field culture.

Carter's Imperial Hardy. An English variety resembling the preceding. Very productive and of fine quality.

Monarch or Tankard. This is a yellow fleshed sort having very large tankard shaped roots, with relatively small necks and tops. Color purplish crimson above ground, yellow below; flesh very solid, fine grained and of the

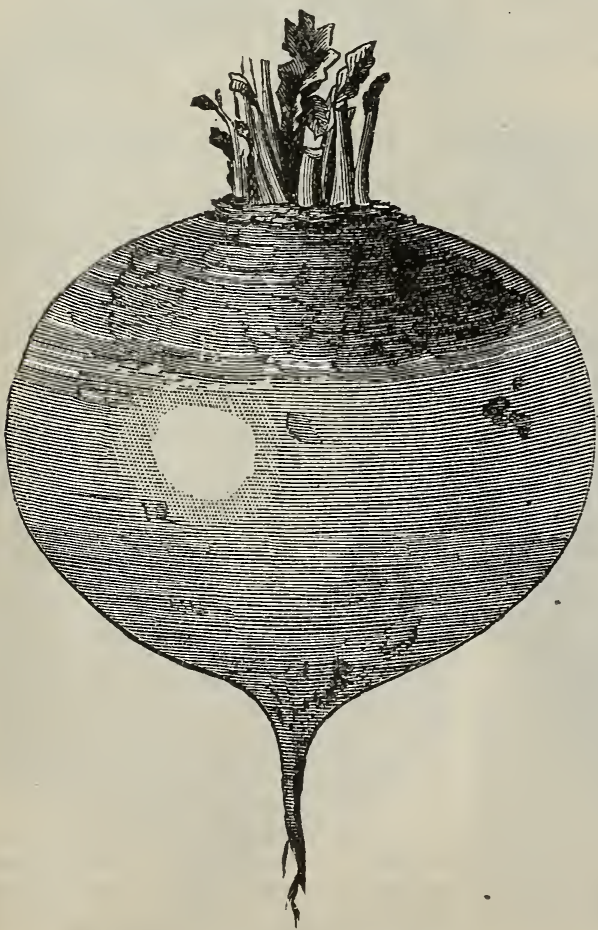
best flavor. This very popular variety is also sold as Hurst's Monarch and Carter's Elephant.

Drummond's. An improved strain of purple top Swede, excelling in uniformity of shape, color and quality. Considered by many an excellent table sort.

Improved American. The best yellow fleshed, purple top variety grown for stock or table.

Budlong's White Rock. Though sometimes called a turnip this is more like a rutabaga. The root is large, both skin and flesh very white, and is one of the best varieties we have for table use. An excellent keeper and a desirable sort for market gardeners.

Bangholm. A very superior variety, both in form and quality, and held in high estimation in many parts of England. Of large size, small $\bullet$ neck, few or no side roots, and yields well. Flesh, yellow, sweet and solid; skin yellow with purple top.

Prices of all varieties of Rutabagas are: Pkt., $3 c ; 0 z ., 5 c . ;$ $\frac{1}{4} \mathrm{lb} ., 15 \mathrm{c}$.; lb., 50c., post=paid.

For feeding stock in fall and winter there s nothing su= perior to Turnips and Rutabagas, as they are much liked by all kinds of stock and served to keep them in good condition. We cannot too earnestly recommend farmers to increase their sowings largely, for we are sure the crop will prove remunerative. This wholesome and agreeable vegetable is most easily affected in its form and flavor by soil, climate and mode of culture. There are a great many varieties, but our list comprises the best for the garden or farm. 


\section{SEED POTATOES}

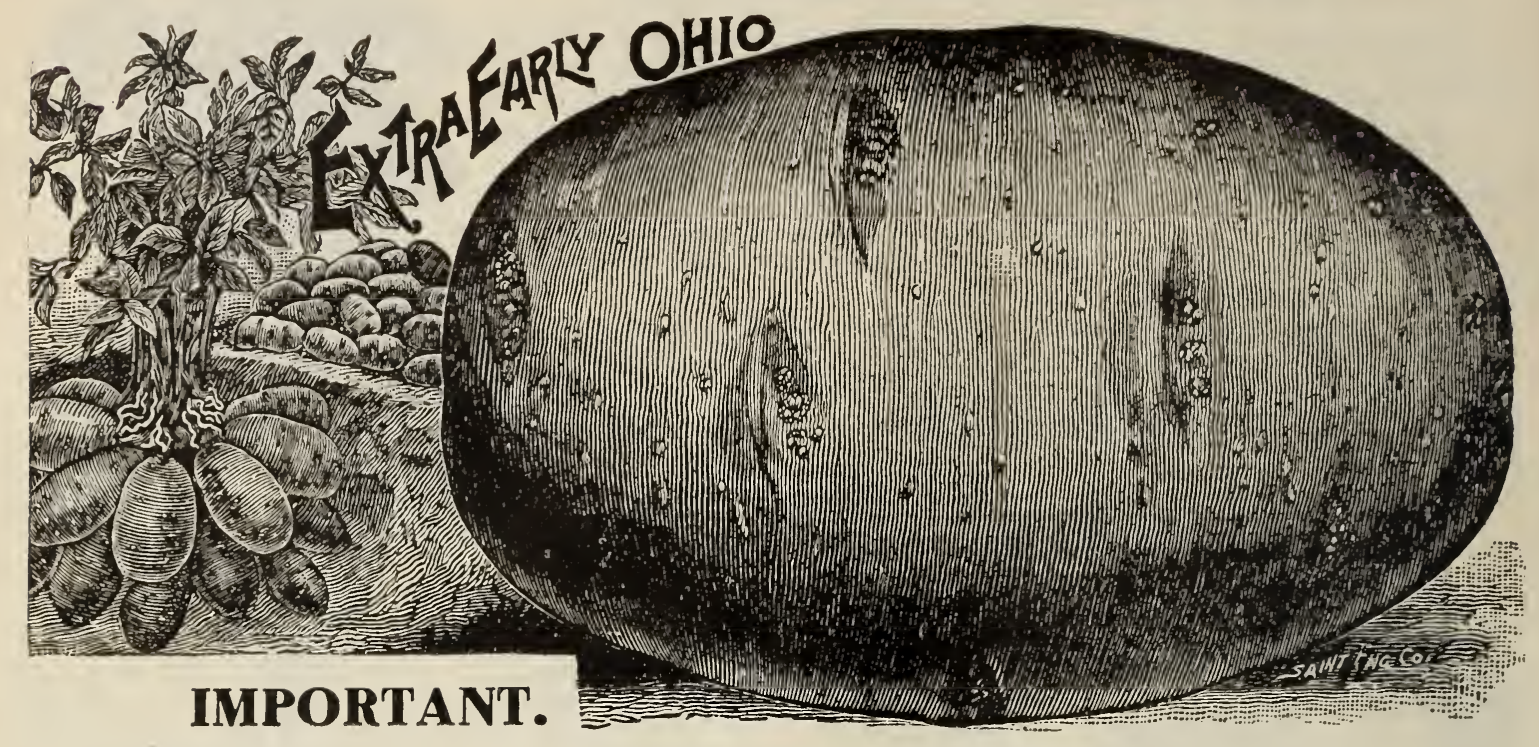

Potatoes are forwarded by express or freight as directed, and are delivered to the transportation com= panies safely packed; after that our responsibility ceases. Purchasers must take all risks from freezing or heating. NO CHARGE FOR BARRELS OR CAR= TAGE TO THE DEPOTS.

\section{EARLY VARIETIES.}

Extra Early Ohio. Absolutely the First Early Potato on the market. No other potato is so profitable for early use and is the favorite of all Chicago market gardeners. A short, thick, round, oblong potato. In color it is a dull red. The flesh is solid, of extra good quality and flavor; very mealy even when only partially grown. Pk., 50c.; Bu., \$1.50; Bbl., \$4.50.

Early Rose. This well-known variety is still very popular. Pure seed is hard to get. Ours is as pure as any to be had. Pk., 50c.; Bu., \$1.50; Bbl., \$4.50.

Early Six Weeks. Claimed by some to be earlier than the old Ohio, and although we see very little difference they are preferred by some of our gardeners. Pk., 50c.; Bu., \$1.50; Bbl., \$4.50.

Early Thoroughbred. This variety resembles the Early Rose very much in size, color and shape. The quality is very superior. An enorinous producer. Pk., 50c.; Bu., \$1.50; Bbl., \$4.50.

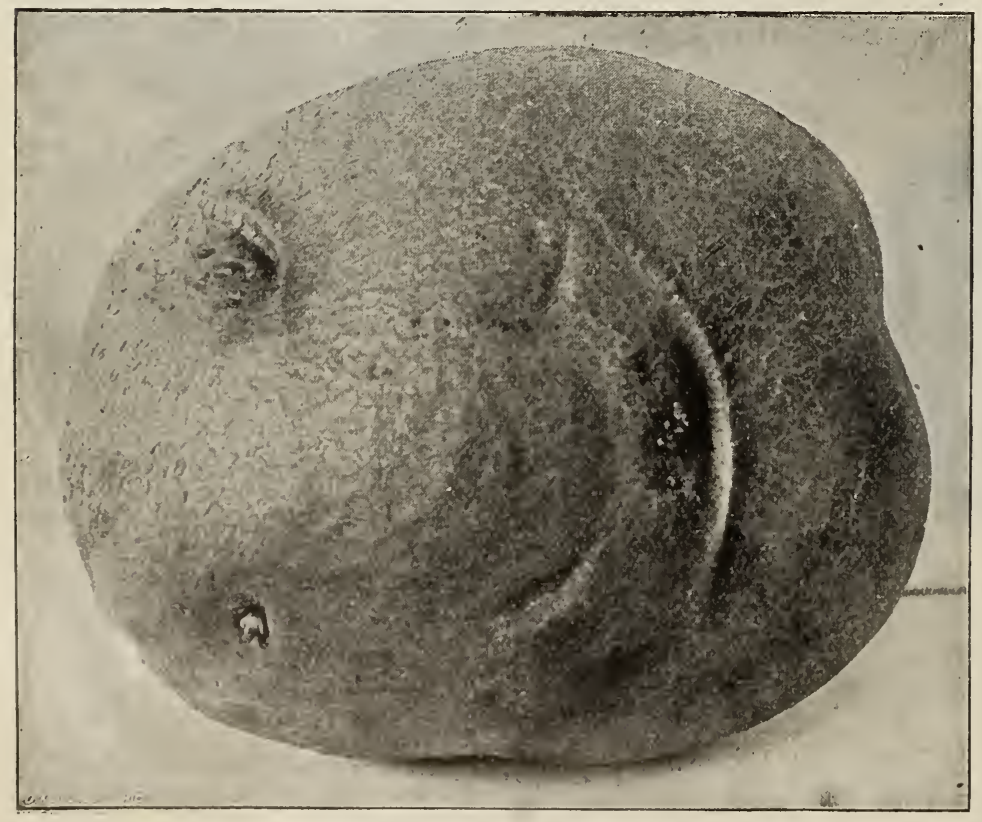

RURAL NEW YORKER No. 2

\section{MAIN CROP VARIETIES.}

Carman No. 1. Intermediate in ripening and resembles the Rural New Yorker No. 2 in shape and also having very few and shallow eyes. The flesh is white and quality perfect. An enormous producer of very large, handsome tubers. Pk., 50c.; Bu., \$1.50; Bbl., $\$ 4.50$.

Carman No. 3. Is one of the best late varieties, also one of the greatest yielders. Large, oblong, slightly flattened. Pk., 50c.; Bu., \$1.50; Bbl., $\$ 4.50$.

Rural New Yorker No. 2. A valuable variety of large size, very smooth and a great cropper. In quality it is unexcelled. It is the best late long keeper and is highly recommended. More potatoes of this sort are shipped annually than any other sort, and their large, handsome appearance make them more profitable than any other sort. Pk., 50c.; Bu., \$1.50; Bbl., \$4.50.

Potato prices are subject to market changes. Customers desiring larger quantities than single barrel lots may find it to their advantage to write for quotations before placing their order. 

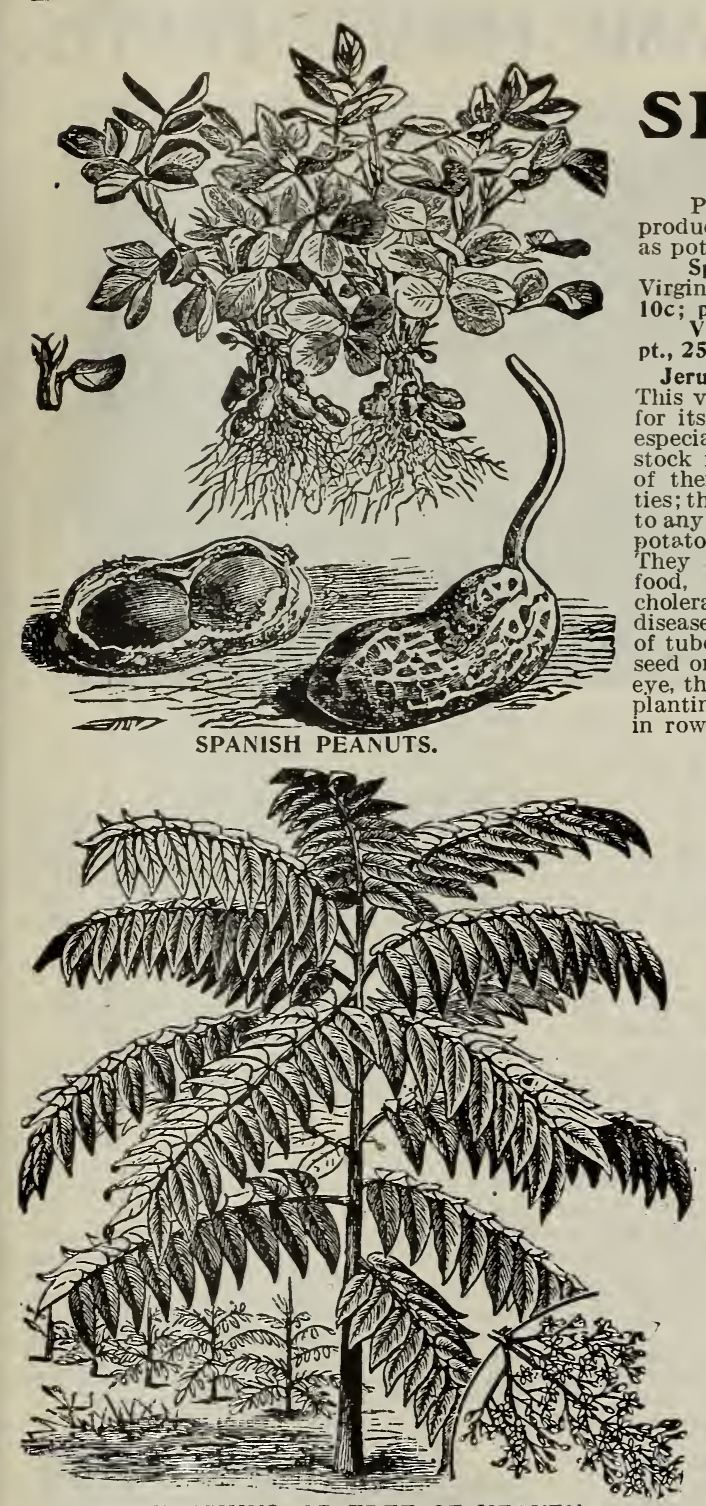

AILANTHUS, OR TREE OF HEAVEN

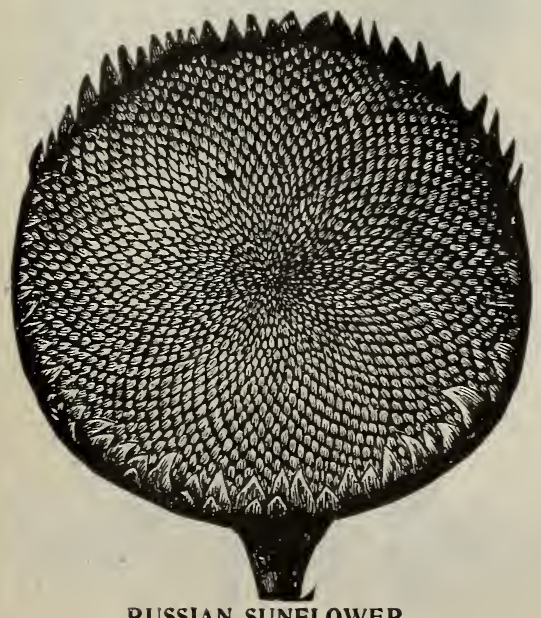

RUSSIAN SUNFLOWER.

\section{MISCELLANEOUS SEEDS AND ROOTS.}

PEANUTS.

Peanuts can be raised with but little expense, and are an exceedingly productive and paying crop. They are planted in much the same manner as potatoes, and require but little care beyond hilling up the young plants.

Spanish. This variety is smaller and sweeter than the common, or Virginia. Plants grow upright and strong, and are easily harvested ${ }_{\text {. Pkt. }}$ $10 \mathrm{c}$; pt., 25c.; qt., 50c.

Virginia. This is the common peanut grown in the South. Pkt., 10c.; pt., 25c.; qt., 50c., postpaid.

Jerusalem Artichoke.

This variety is cultivated

for its tubers, which are

especially valuable for

stock feeding on account of their fattening properties; they are well adapted to any soil where corn and potatoes can be grown They are the best hog food, a preventive of cholera and other hog of tubers are sufficient to seed one acre; cut to one eye, the same as potatoes, planting in A pril or May planting in A.pril or May 2 fee' in the rows. and cover about 2 inches deep. Lb., 25 i.; 3 ibs. for 6.5c., postpaid ; by freight or express. pk., 50c.; bu., , bbi. of 3 one a cre), $\$ 4.00 ; 2$ bbls. for $\$ 7.00$, on bbis. for $\$ 7.00$,

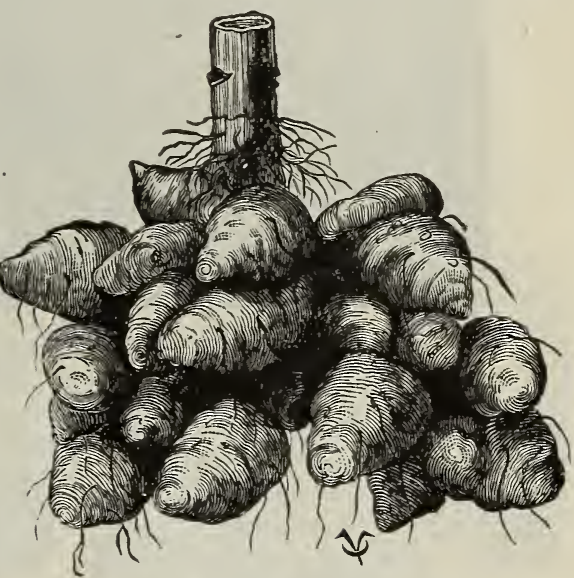

ARTICHOKE, JERUSALEM.
Ailanthus. (Tree of Heaven.) This splendid ornamental tree is a native of China, where it is called the Tree of Heaven, from its great beauty. It is very hardy, and thrives in any soil, no matter how poor, and grows from 6 to 10 feet high from seed the first summer. The leaves, from 5 to 6 feet in length, give it a grand appearance. Nothing outside the tropics can rival it for lawn decoration. Large panicles of bloom, followed in season by great clusters of colored seed pods, make the tree a continual thing of beauty. The cut represents a portion of a tree in bloom, and also a seedling tree four months from sowing. For beautifying lawns and flower beds nothing can be finer, they being even more beautiful than Ricinus or Cannas. Pkt., 5c.

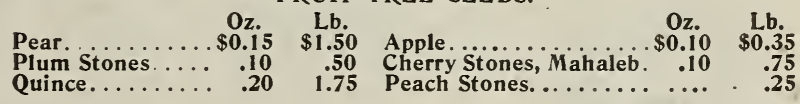

We would call the attention of everyone who has a garden to our Barker Hand Cultivator on page 104. This tool will save its cost many times over by adding to the product of your garden.

FOREST TREE AND HEDGE SEEDS.

EVERGREEN

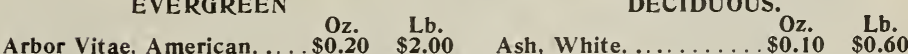
Fir, Silver.

Pine, Scotch.

Pine, Scotch............... $\quad .20 \quad 2.00$

$\begin{array}{llr}\text { Pine, Weymouth or White... } & .20 & \mathbf{2 . 0 0} \\ \text { Spruce, Norway.......... } & .15 & 1.25\end{array}$

For Poultry Supplies See Page 97.

Ash, European.

Birch, White. .

Larch, European.

Linden, European

Locust, Honey...

Locust, Yellow.

Mulberry, White. .

$\$ 0.10 \quad \$ 00$

$.10 \quad .60$

$.15 \quad 1.50$

$.10 \quad .75$

$.10 \quad .50$

$.10 \quad .50$

$\begin{array}{ll}.20 & 2.00 \\ .25 & 2.50\end{array}$

Russian Sunflower. This is highly prized by poultry raisers and farmers as a cheap food for fowls. It is immensely productive and can be raised cheaper than corn, as any waste piece of ground will suffice. It is the best egg producing than corn, as any waste piece of ground 10c.; 1b., 20c. Not prepaid: $101 \mathrm{lbs}$., 75c. 25 lbs., \$1.50; 100 lbs., \$5.00.

Beggar=Weed. (Florida or Giant Beggar-Weed; Desmodium tortuosum.) An erect leguminous annual, growing from 3 to 8 feet high, with abundan foliage, valuable as forage or for soil renovation in sub-tropical regions. It is highly recommended for improving light, sterile sandy soils by plowing under ind it also makes hay of a fine quality. It should be sown at the rate of 10 pound an clean seed to the acre after the of clean seed to the acre, after fhe ground it should be cut just as it begins to bloom. Lb., 45 c.; 5 lbs., $\$ 1.75$; prepaid. By express. 5 lbs., \$1.35; 10 lbs., \$2.50. 


\section{MISCELLANEOUS GRAINS AND FORAGE PLANTS.}

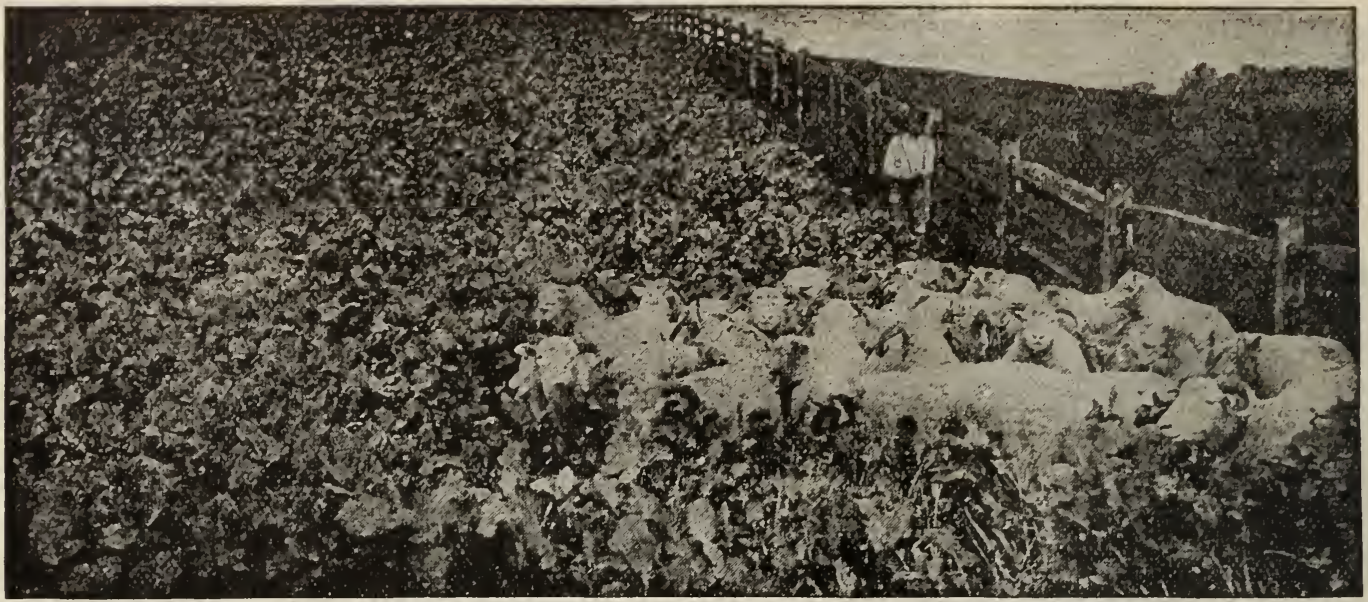

PHOTOGRAPH OF A FIELD OF ESSEX RAPE.

DWARF ESSEX RAPE.

A forgage plant of great merit, easily grown in any part of the United States, on any land that will raise turnips or corn, and will A forgage plant or great mert, easily grown in will furnish abundant supplies of succul nnt, rich, nutritious pasture, at a season when it is most needed. It is of great value for sheep and lambs, and when turned on it, to use a common expression, "they soon weigh like lead. It is also of value for pasturing cattle. One acre of rape is sufficient to pasture ten to fifteen lambs on for two or two and one-half months. It is often sown broadcast, about five pounds to the acre, but will yield much better if drilled about two pounds to the acre, in rows twenty-two inches however, be sown with grain in the spring, and is said not to interfere with the grain crop. Price subject to change. Lt., 20c.; 3 lbs., 50c., postpaid. By express or freight, Write for prices.

\section{SUGAR CANE.}

Early Amber. Its early maturity adapts it almost to every section. It has given entire satisfaction wherever introduced section. Itiale crop for fodder as well as for sugarmaking. It usually grows 11 to 12 feet high and stands well. If planted the first week in May the seed almost invariably ripens, thus giving a double crop each year, yielding 20 to 30 bushels of seed and 140 to 175 gallons of syrup to the acre.

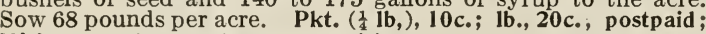
Write for prices on larger quantities

\section{BROOM CORN.}

Tennessee Evergreen. More largely grown in the western states than any other. The brush is noted for its fine quality good length and handsome appearance, cut before the seed is ripe, it is a beautiful pea green color. It ripens early and vields heavy crops. Lb., 25 c.; 3 lbs., 65 c., postpaid. Write for prices on large: lots.

Missouri Evergreen. Has coarser brush than the Tennessee and is therefore desirable for making heavy brooms. Lb., 25c.; $3 \mathrm{lbs}$., $65 \mathrm{c}$., postpaid. Write for prices on larger lots.

Teosinte. A valuable fodder plant from Central America, in growth resem bling Indian Corn. Well adapted to our Southern states. Oz., 20c.; lb., \$1.25. Lathyrus Sylvestris. (Flat Pea.) A new perennial forage plant, possessing many valuable features. It grows well on very poor, unimproved, sandy soil, can withstand pretty severe frosts, roots so deeply that it is not injured by ities as a fertilizer. Oz., 20c.; 1b., \$1.40.

\section{SEED BUCKWHEAT.}

Japanese. The kernels are at least twice the size of those of any other variety, and of a shape peculiar and distinct from all others. The color of the kernels is also most distinct, being a rich, dark shade of brown. The straw is heavier, very branchy, and does not need to be sown as thickly as other kinds. The quality is excellent and the yield is enormous. It is about a week earlier in ripening than the Silver Hull. $100 \mathrm{lbs}$., write for price.

Silver Hull. This improved variety is much better than the old sort. It is in bloom longer, matures sooner, and yields double the quantity is thinner, the corners less prominent and the grain of a beautiful light gray color. The flour is said to be better and more nutritious. $100 \mathrm{lbs}$, write for price.

Common. Buckwheat should be sown about the 20th of June broadcast, at the ate of from 1 to 3 pecks per acre. The average yield is from 25 to 30 bushels per acre. It should be threshed as soon as dry, on the ground or barn floor. If llowed to stand in mass it quickly gathers moisture. 100 lbs., write for price.

The prices vary on all Grass and Clover Seed and on Farm Grains. We sell at the market price on day of ship= ment and send accordingly. Write for latest market price.

\section{LUPINS.}

Blue. Used for the same purpose as the yellow variety.

White. One of the best plants known for soiling. It may Lb., 30c.

Yess thrifty than the white variety, but stil It succeeds well in the poorest soil, and is valuable

Egyptian Lentils. Largely used in oriental countries, and s one of their principal articles of diet. It was from these that the dish of pottage was made for which Esau sold his

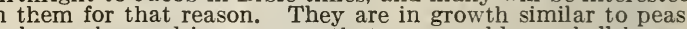
and may be used in any way that you would use shell beans, and they also make an excellent soup. Sow and cultivate same as garden peas, and thresh out in the fall. All should Pkt., 5c.; Oz.. 10c.; 专 lb., 15c.; 1b., 30c.

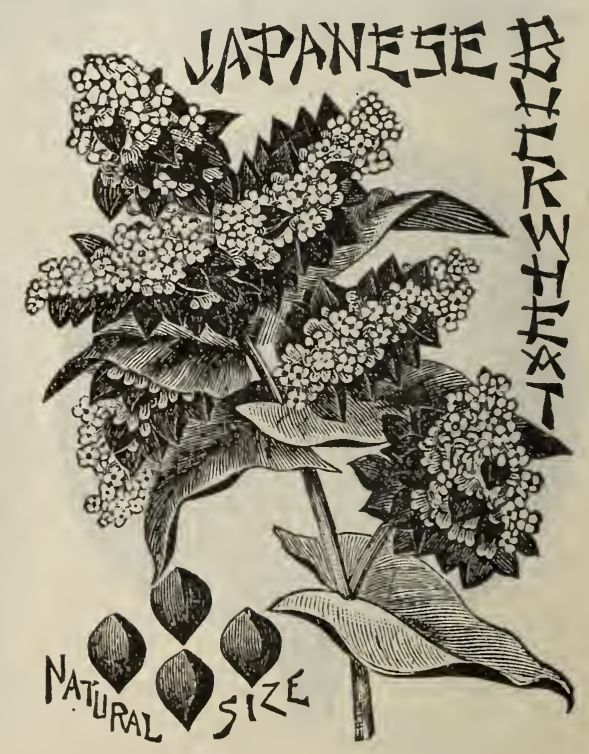




\section{MISCELLANEOUS GRAINS AND FORAGE PLANTS-Continued.}

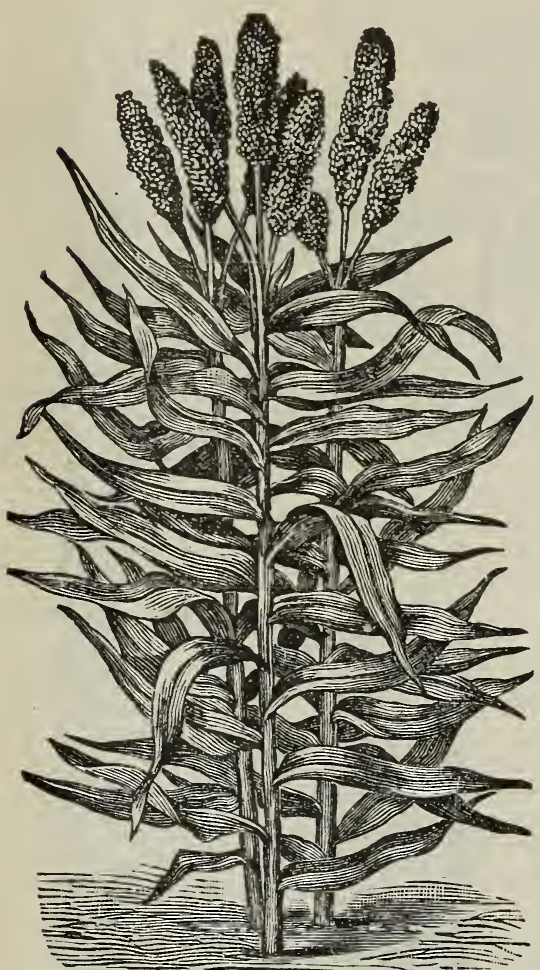

KAFFIR CORN,
DHOURA CORN.

Brown. Lb., 20c.; 100 lbs., market price.

Yellow Branching. (Yellow Millo Maize.) It is non-saccharine. Useful only for the large amount of foliage, green feed or cured fodder that it furnishes, and for its grain. Lb., 20c.; $100 \mathrm{lbs}$., market price.

White Branching. (White Millo Malze.) The merit of this non-saccharine sorghum is that when cut for feeding it starts again from the remaining stumps with renewed strength and vigor. Thrives in the hottest and driest localities. Lb., 20c.: 100 lbs., market price.

Jerusalem Corn. One of the best and surest for dry countries and seasons. Grows about three feet high, with one large head on main stalk and several smalle heads on side shoots. The grains are white and nearly flat. Lb., 20c.: 100 lbs. market price.

KAFFIR

\section{CORN.}

Kaffir Corn. One of the best forage plants. If the crop fodder, it is recommended to cut down the wlole stalk when the first seed heads the first seed heads second growth springing at once from the roots, will still mature (in climates similar to crop of grain and a second full crop of forage before the middle of October. Sow in rows 3 feet apart, 3 to 6 pound

White or Red. Pkt., 5c.; 1 lb., 20c.; 3 write for prices on Jarger lots.

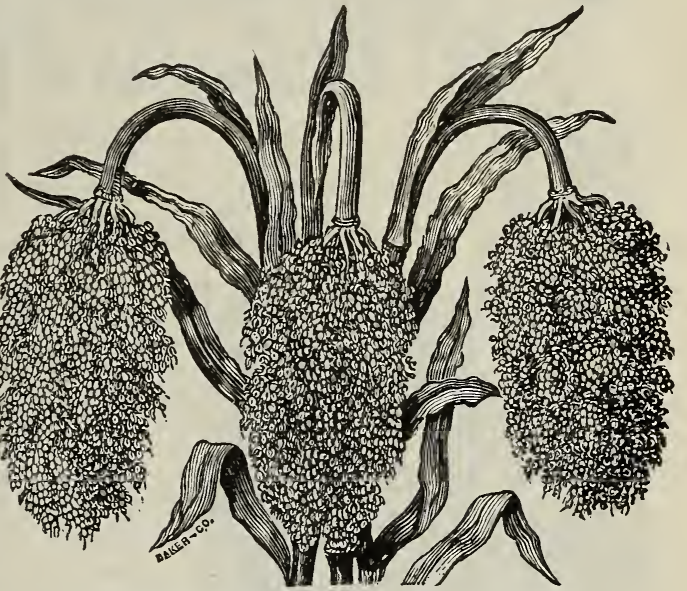

YELLOW BRANCHING DHOURA CORN
Prices vary on all Farm Grains and Forage Plants. Write for latest market price.

\section{VETCHES.}

Spring. (Vicia Sativa.) Sown broadcast at rate of one to one and a half bushels to the acre, like wheat or barley, and sometimes mixed with oats for soiling. Used in France and Can-

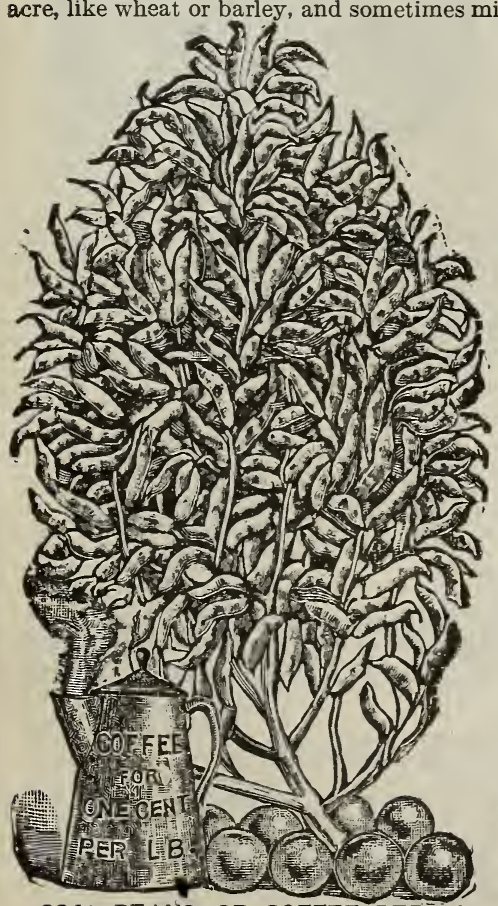

SOJA BEANS, OR COFFEE BERRY ada as a substitute for peas. Also ground up into flour after which it is mixed with wheat flour for making, bread. A valuable plant. Qt., 35c.; bu., market price.

Sand, Winter or Hairy. (Vicia Villosa.) This variety thrives on poor, arid, sandy soils. It is sown either in fall or in spring, and generally mixed with rye, which serves as a support to the plants. It grows to a height of from 3 to 4 feet, and can be cut twice for fodder, first as soon as the bloom appears, and then it can be again cut for the seed. The plant is perfectly hardy, and the produce is recommended as most nutritious. The seed is black and perfectly round, and should be sown at market price.

\section{BEANS.}

Velvet Bean. (Dolichos Multiflorus) This new bean is becoming very popular in the South and middle North. It is very prolific, vines running over 12 feet long; both vines and pods are eaten by for plowing under. At the Experiment Stations it has given wonderful results as a fertilizer. Should be planted in rows about 4 feet apart and 1 foot apart in the row, putting 2 or 3 beans in each place. The culture is the same as for Cow Peas. Pkt., 10c.; lb. 25c., postpaid. Write for prices on larger quantities.

Soja Bean, or Coffee Berry. This valuable forage plant is one of the most nutritious of all vegetable products. It will produce a crop of 20 to 30 bushels per acre, and is as easily grown as other beans. For pasturing or feeding as green fodder it is very valuable, and nearly equal to clover for fertilizing. When roasted and coarsely ground the beans taste so nearly like Brazilian coffee the difference is scarcely perceptible. It is certainly the best of all substitutes for coffee yet found Sow one-half bushel per acre broadcast, or one gallon per acre in drills $3 \frac{1}{2}$ feet apart and $1 \frac{1}{2}$ feet between the plants, dropping two or three in a hill. Price, large pkt., 10c.; $\frac{1}{2} \mathbf{l b}$., 30c. ; lb $35 \mathrm{c}$ postpaid. Write for prices on larger quantities.
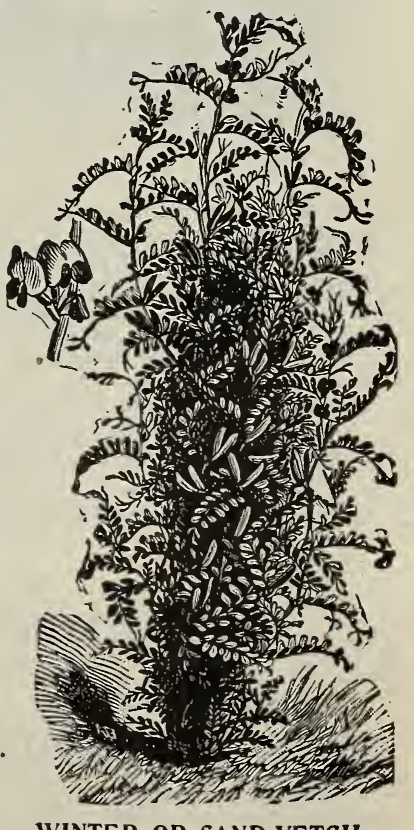
. 


\section{MISCELLANEOUS GRAINS AND FORAGE PLANTS-Continued.}

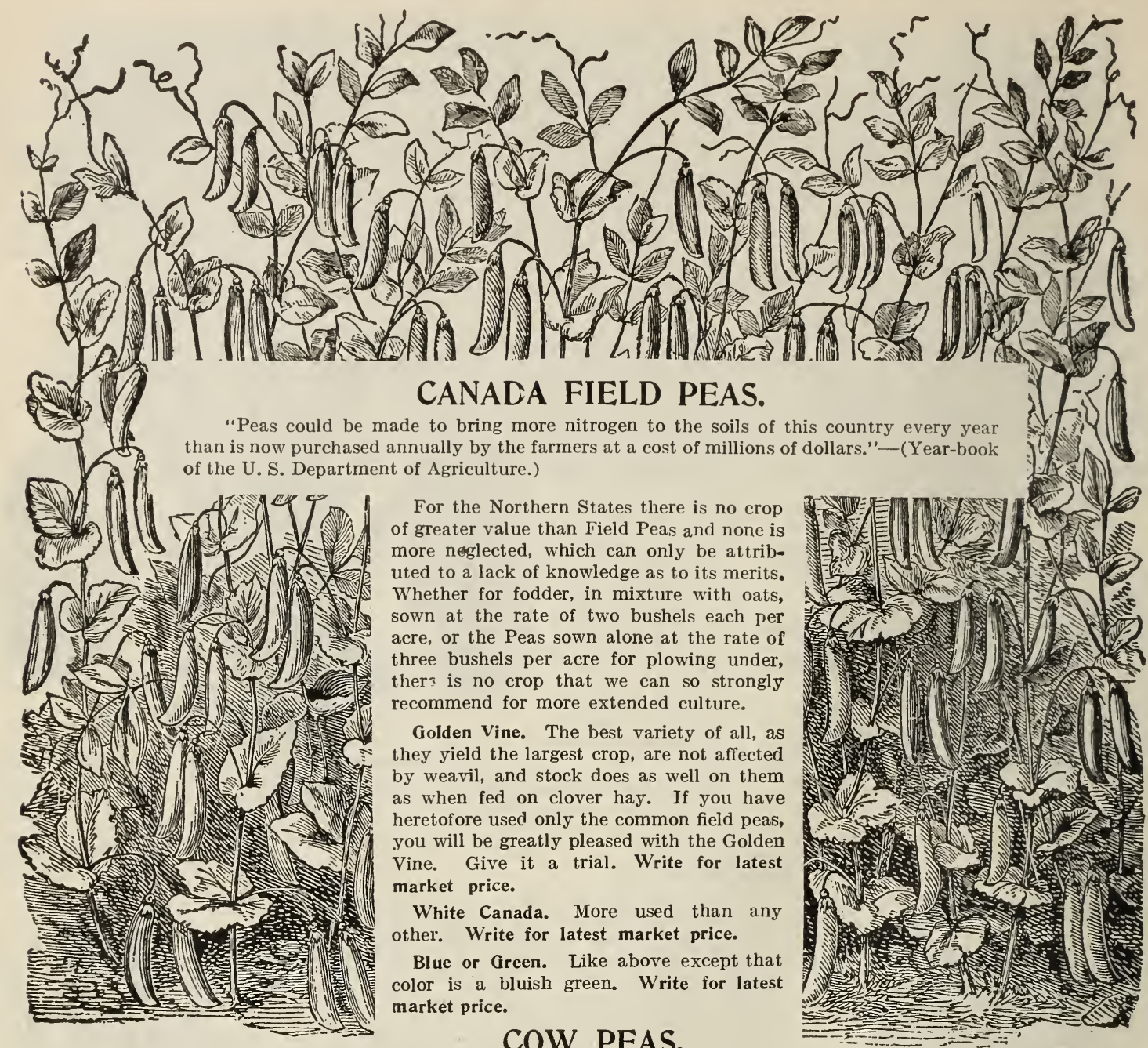

Note - Cow Peas are held in very high esteem for forage purposes, especially on sandy soils. It has been said that the Cow Pea has almost as much agricultural importance in the South as red clover in the North or alfalfa in the far west. Great changes are now in progress, however, in farming methods and there is today a wide spread disposition to plant Cow Peas farther nortl than formerly, on account of their quick growing habit, their drought resisting ability and their great value for silage and soil improvement purposes. They will thrive wherever conditions favor corn. The yield of green fodder per acre often reaches five tons, and is sometimes as much as eight or nine tons. Some growers turn the mature vines under with the plow. Some harvest the hay and plow down the stubble. Others ripen and pick the seed, and then plow the vines under. Some Cow Peas are trailers, with very long vines; others assume the bush form Sow seed at the rate of 1 to $1 \frac{1}{2}$ bushels per acre. The Cow Pea is a nitrogen gatherer, and hence improves the soil.

Black Eye. Seed large, round, oblong, creamy white, with a large black eye.

Whip=Poor=Will. The seeds are large, speckled brown in color.

Black Seed all black. Called also "The Poor Man's Pea," on account of its wonderful prolificacy.

Clay Colored. Large Seed of a blue clay color.

The prices on Cow Peas and Field Peas vary with the market. Write for latest market price.

\section{WILD RICE.-(Zizania Aquatica.)}

The only one of our native plants furnishing food for wild fowl, ducks, geese, etc. which has been made an article of commerce. This seed can be sown on the borders of lakes, ponds and along small streams to great advantage, attracting all of these wild birds from September on. It purifies the water and affords refuge to the small fry from the large fish. It makes a good hay, and at the south two crops can be cut, and all cattle are fond of it. Sow in water having a mud bottom. Lb., 30c. postpaid. W r ${ }^{4}$ e for prices on larger quantities.

\section{BROMUS INERMIS, OR AWNLESS BROME GRASS.}

The greatest of all grasses, succeeds and poduces immense crops of high nutritive value on the sterile and arid plains of our Western States, greatest of all grasses, succeeds and poduces immense crops of high nutritive value on the sterile and arid plains of our Western 10 years. It is one of the on dry sandy soils, where other grasses would perish. It is perennial, and once sown down will stand for the first season, followed aftertyards obtain a catch from, establishing itself very rapidly, so much so that a good hay crop can be had can be had from it, often running over five tons of cured hay per acre. When fully grown the plant stands from 4 to 5 feet in height and stools out freely, it is ready to cut the latter part of June. Lb., 25c;; 3 lbs., 60c., postpaid; Write for prices on larger
quantities 


\section{MISCELLANEOUS GRAINS AND FORAGE PLANTS-Continued.}

Prices Vary on all Grass and Clover Seeds and on Farm Grains.

\section{SEED RYE.}

Fall or Winter. The time for sowing is from the middle of August to the last of September. One plowing is given and the seed sown broadcast at the rate of one and one-half bushel per acre, and dragged in. Harrowing and rolling in the spring are recommended. If cut before fully ripe the grain makes more and better flour; if intended for seed it should be fully ripe. Sow some rye among standing corn, hoeing it in leaving the ground level as possible after the corn has been removed, rolling the ground. It succeeds best on sandy soil in, leaving the ground

Spring. Although this grain is often planted by farmers especially for the paper makers, who prefer it to any other, its principal value is as a "catch" crop, to sow where winter grain has failed. The straw is shorter and stiffer than that of the winter variety, and is always easier secured, while the grain, although smaller, is of equal value. Write for Market Price.

\section{MILLET SEED.}

Please note that Millet Seed is Sold by the $100 \mathrm{lbs}$; bushel price would be one=half the $100 \mathrm{lbs}$. price.

Siberian. A new and wonderfully productive forage plant from Russia, which has given excellent results in the United States. Lb., 25c., 3 lbs., 60c, postpaid. Write for Prices on larger lots.

in drills eighteen inches apart, Sow 8 on larger lots.

Hog. Known also as Broom Corn Millet. Quite unlike the German and common millet in habit of growth as well as the appearance of the seed which is much larger phasize the use to which it is now being put as an economical and valuable food for hogs, while it is also one

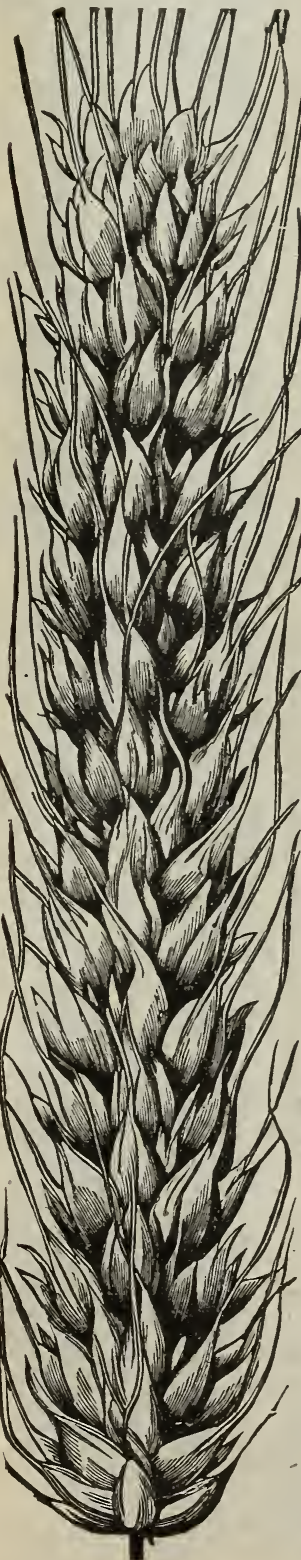
of the best varieties for use for bircls and all like commercial purposes for which millet is sown. It is a valuable help to the profitable raising of swine, even in the best corn belts, and of much greater value in all northern localities where corn is not so important a crop. Lb., 25c., 3 lbs., 60c., postpaid. Write for Prices on larger lots.

Japanese Barnyard. (Panicum Crus Galli.) This wonderful and valuable new forage plant was introduced into this country by Prof. Brooks, of the Massachusetts agricultural experiment station. It has proven an enormous yielder in all sections of the

Common. (Panicum Miliaceum.) Requires a dry, light, rich soil, and grows two and one-half to four feet high, with fine bulk of stock and leaves, and is excel lent for forage. Sow broadcast from May 1 to June 20 , if for seed, or until the last of July, if for hay. Per 100 lbs., Market Price.

German or Golden. This variety is not so early as the Common millet, but yields a much larger crop. Southern grown seed is much preferred as it will produce more hay. Northern grown seed is usually hybridized with other millets, and will not grow as tall. We can furnish southern grown seed. Per $100 \mathrm{lbs}$., Market Price.

Hungarian Grass. (Panicum Germanicum.) A valuable forage plant. Succeeds well on dry, light soil. Withstands the drought remarkably, remaining green when all other vegetation is parched up, and if its development is arrested by dry weather, the least rain will restore it to vigor. Market Price.

\section{PENCILLARIA.}

A wonderful forage plant of great value to all stock farmers. It is unexcelled, if equaled, for its quick growth, immense size and splendid quality. The seed is small, about the one-eighth size of a grain of wheat; it should be planted about the first of May, and will grow and stool or tiller out surprisingly fast. Its growth is truly luxuriant, the broad foliage resembling corn leaves, and if allowed to develop will attain a height of twelve to fourteen feet, and bears cylindrical heads from twelve to twenty inches long, closely set with thousands of tiny seeds, which are greatly relished by poultry. A crop of this when nearing maturity looks like a postpaid. Write for Prices on larger lots.

FLAX.

Russian. We have some very choice seeds of this, much superior in every way to common flax. It will increase the yield and add to the value of the product. Most of the flax of the country is badly run out. It will pay you well to secure some new seed. Write for Prices.

\section{AUSTRALIAN SALT BUSH.}

A forage plant for alkali soils, and for regions subject to periodic drought. This is a most wonderful forage plant, as it will grow freely in arid and alkali lands that will produce no other vegetation, yielding a marvelously liberal foliage which is eagerly eaten by all kinds of stock. It is of creeping habit. From twenty to thirty tons of green fodder have been harvested from one acre. It has further been proved that after three or four crops have been grown on alkali land the soil is then capable of producing any other regetation. In many sections of the States this is in itself of priceless value. The plant has been very extensively tried at the California experimental station, where single plants, grown on the poorest alkal ground, have reached a diameter of sixteen feet in one season. One pound of seed 10c., oz., 20c., 立 lb., 65 c., lb., $\$ 1.75$.

\section{GIANT SPURRY.}

An annual plant extensively cultivated in Europe as a winter pasture for cattle and sheep; grows well on poor, dry, sandy soil; an excellent fertilizer for light soil, and valuable for forage. Sow 12 lbs. per acre. Price, per lb., 25c., 3 lbs., 65c., postpaid. Express, 5 lbs., 70 c., 10 lbs., $\$ 1.30$.

\section{SAINFOIN or ESPARSETTE.}

An excellent pereninial Fodder Plant, growing about 3 feet high, flowering in June and July. It is adapted for light, chalky soils, being an enriching, heat-resisting clover; does well in Southern and Western States. May be sown in drills or broadcast. Sow 25 lbs. per acre broadcast; 12 to 15 lbs, in drills. Write for Prices.

\section{JOHNSON GRASS-(Sorghum Helepense,)}

A popular grass in the Southern States. Valuable for fodder, growing 30 inches or more in height. It is a rapid growing perennial. On rich soil it may be cut three or four times in a season. Sow 20 to 25 lbs. per acre, Write for Prices.

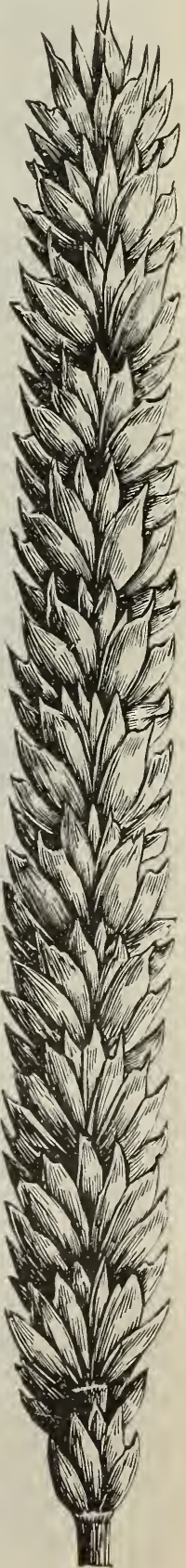




\section{FARM GRAINS.}

The Prices on all Grass Seeds, Millet Seed, Farm Grains and Forage Plants change with the market. Customers should write for latest market prices. The values vary from time to time, and frequently rise or fall sharply within a short period of time. For this reason we do not print any prices for large quantities.
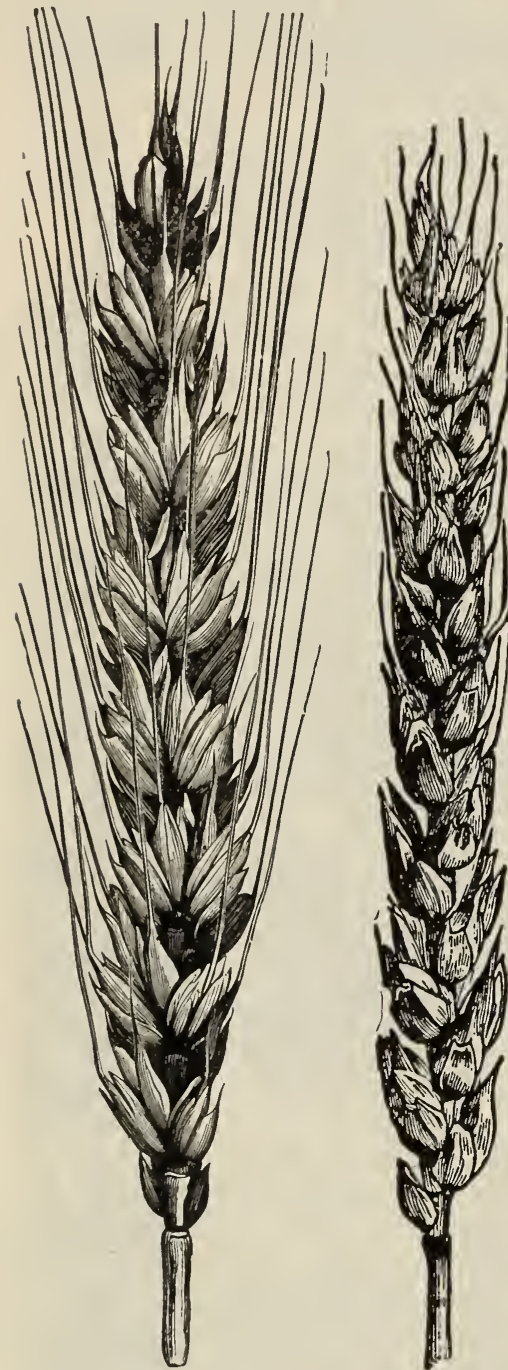

MANSHURY BARLEY. SPELTZ.

Speltz or Emmer. The raluable new grain from Russia. It is readily eaten by all kinds of stock, and has shown itself to be especially adapted when fed to milch cows. It is better to mix it, however, with bran and shorts, as it is a pretty heavy feed when fed alone. As a swine feed we think very well alone. As a swine feed, we think very well of it, indeed, especially for breed sows. is equal to oats in that case. Its most striking value is found in the fact of its drouth-resisting qualities. The United States Department of Agriculture has issued a bulletin on Speltz, commending it highly and the introductory paragraph of that "The extremely variable climatic conditions in some of our western states have made it desirable to give particular atten drouth. Among such especially to cold and drouth. Among such crops Emmer holds prominent crops for stock feeding ", Lb., Market Price on larger lots.

\section{SEED BARLEY.}

Manshury Barley. A six-rowed barley, well-known and popular. Very productive, hardy, vigorous, and profitable. Larger lots. $3 \frac{1}{2}$ Ibs., 50c., postpaid. Write for Prices on Beardless Barley. This barley is much thought of by all who have grown it. It is a very productive variety. Makes excellent feed for swine, and is preferred by brewers Write for Prices on larger lots.

White Hulless Barley. This variety of Hulless Barley is the best. It is highly prized in the Northwest, where it has been grown for a number of years and is becoming very popular everywhere. Lb., 15c., $3 \frac{1}{2} \mathrm{lbs}$., 50c., postpaid. Write for Prices on larger lots

Highland Chief Barley. This popular two-rowed barley is one of the best of the standard sorts. It is very productive, and the berry is large. Lb., 15c., 31 Ibs., 50c., postpaid; pk., 40c. Write for prices on larger lots.

\section{SEED WHEAT.}

Velvet Chaff Blue Stem. This is a very superior milling wheat. It is the most popular in many of the spring wheat growing sections. It makes a good crop wher 50c., kostpaid. and is reliable al ways. Larger quantities.

Saskatchewan Fife. This well-known standard variety has been widely grown for many years, and it is still as popular as ever. Write for Market Price.

Minnesota No. 169. This is a new variety and is an improvement over any known sort of productiveness. It is the result of many experiments in crossing. Lb., $20 \mathrm{c}$ $3 \frac{1}{2}$ lbs., 50c., postpaid. Write for Prices on larger quantities.

Macaroni Wheat. This is a new variety highly spoken of by the United States Department of Agriculture for the semi-arid districts. The best quality of grain for macaroni, according to experiments, is grown in the dry districts.

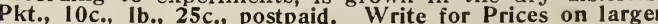
quantities.

\section{TURKESTAN ALFALFA.}

This most valuable new variety was sent out by the Department of Agriculture four years ago in a small way, and it has given such excellent satisfaction that we have now decided to list it. It is more hardy than the ordinary variety, having stood a temperature of 40 degrees below zero when the ground was bare. It will also stand extreme drouth, as it comes from a locality where the summers are dry and hot and the winters extremely cold. We believe that the farmers of this country will find it of special value, making not only a larger top growth but much better root growth Prices: Pkt., 10c., lb., 40c., $3 \mathrm{lbs} ., \$ 1.00$, postpaid. Write for Market Prices on larger lots.

\section{GRASS SEED MIXTURES FOR MEADOW AND PASTURE.}

For every different kind and condition of soil there is a large number of grasses, either indigenous or introduced, which are especially suitable. Some sorts do best on high ground and in dry weather, others prefer plenty of moisture. Some mature so early, and others so late, that from the beginning of spring until winter sets in, there is no time when one species or another is not at its best. From these considerations the impiortance of sowing many varieties for pasture or meadnw purposes will be apparent Successful farmers recommend heavy seeding. The quan tity that should be sown per acre depends upon the location and nature of the soil. There is a wide difference of opinion on this subject and the actual quantity of seed necessary should be determined by some one conversant with the local situation. purpose and we will quote you low prices.

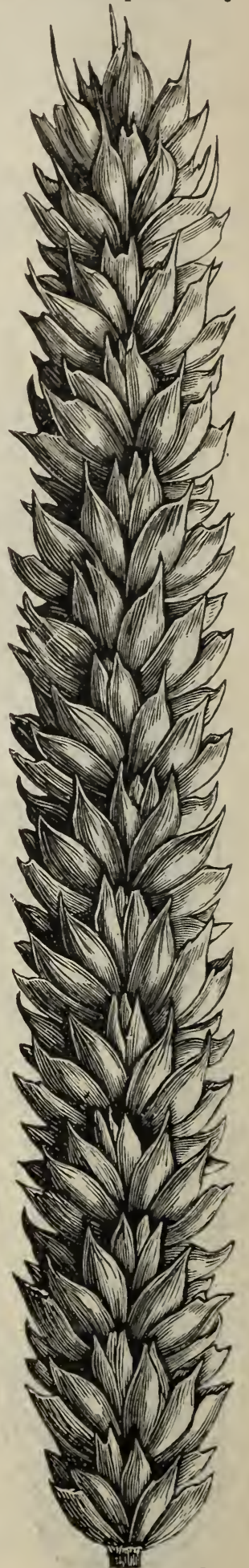

VELVET CHAFF

BLUE STEM. 


\section{FIELD CORN.}

Any Variety of Field Corn, 1 lb., 20c.; 3 lbs., 50c., Postpaid.

Extra Early Huron Dent. After several years' trial on a large scale it is concluded that this is one of the earliest Dent corns grown Good size stalk and ear, small red cob. corn known. Pk., 40c.; bu., $\$ 1.50$

Pride of the North. This famous corn still retains its popularity. An exceedingly early and prolific variety, always maturing in ninety days, often shelling sixty-two pounds of grain from seventy pounds of ears. Kernels closely set, large, of deep orange color; Dent corn for general cultivation in the north. Pk., 40 c.; bu., \$1.50.

North Star Yellow Dent. One of the best early Dents. A safe variety to ripen in any locality. Pk., $40 \mathrm{c}$.; bu., $\$ 1.50$.

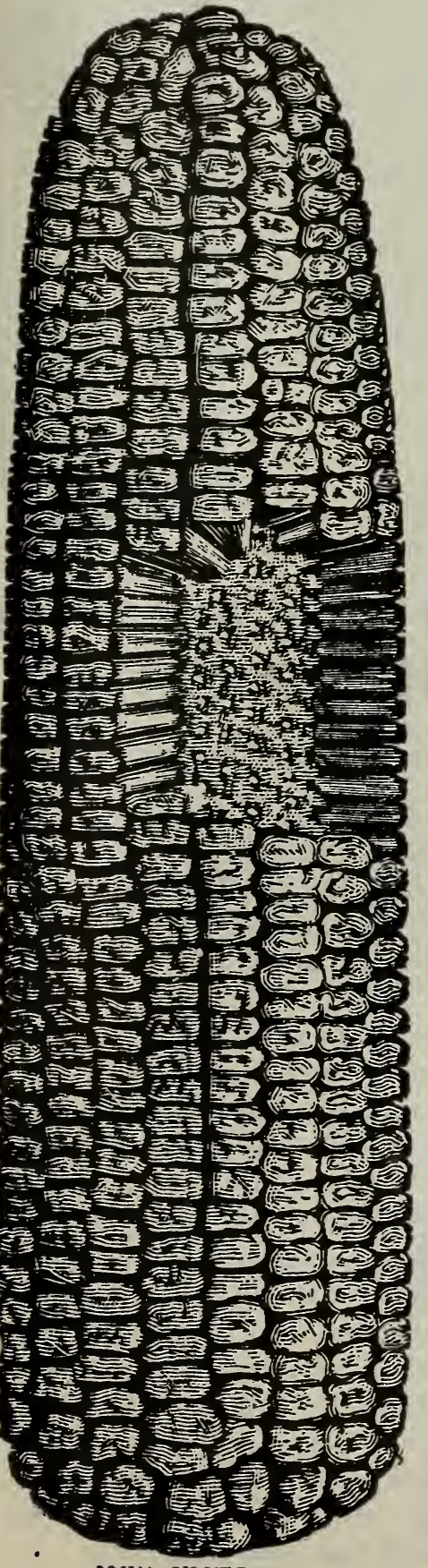

Golden Beauty. A large, broad grained, handsome yellow corn, which is very popular in some sections of the count popular in some sections of the bright golden yellow, cobs small. Pk. 40c.; bu., $\$ 1.50$.

Minnesota King. A very early variety, in great favor with our customers Dakotas, and it is considered there the most profitable and best yielding corn, no matter whether weather is favorable or not. It is a yellow half dent variety. with broad, rich gold

Early Mastodon. A new yellow dent the largest and earliest in cultivation; has yielded 200 bushels to the acre. Pk., 40c.; bu. \$1.50.

Champion White Pearl. Originated in Illinois and is enormously productive; a strong grower; matures in about 100 days. The stalk is stout and thick, with larg.

lowa Gold Mine. A splendid new vellow corn Everyone who has tried it is enthusiastic in the praise of this splendid new variety, which was introduced in 1892 . It has everywhere received the most cordial endorsement as one of the best and most profitable Varieti

Iowa Silver Mine. The Iowa Silver Mowa Silver Mine. The Iowa Silver Melieve that in its yield it will surpass all other varieties of any color. In 1894 , the poor corn year, only three-fourths of an acre was planted, yet it yielded just 73 bushels, or at the rate of ninety-seven and one-third bushels to the acre. It has no barren stalks. The ears are very even in size, being but little smaller at the tip than at the butt, and corn is well filled out over the tip. Pk., 40c.; bu. $\$ 1.50$.

Reid's Yellow Dent. A very good yellow dent corn. In size, shape of ear and color of kernel similar to Leaming. This is one of the yellow dents classed as distinct, and having an established standing as such, by the Illinois Corn Breeders' Association. It is very popular and is considered a most pron growing sections, Pk, $40 c_{\text {. }}$ bu $\$ 1.50$.

Riley's Favorite. This fine yellow dent variety is a favorite in Indiana and in many sections of Illinois. It compares favorably with Leaming, ear not so tapering and kernel not so close lished and its many valuable points recommend it to all corn growers. $\mathbf{P k}_{\text {. }}$ 40c.; bu., $\$ 1.50$.

Golden Eagle. This variety of yellow dent corn is another popular medium maturing variety. Ears are large, slightly tapering, tips and butts well covered, kernels deep, cobs small. The yield of shelled corn from a weighed bushel of ears will usually go over standard. The samples of this corn remind us of the old time Edmonds Premium. Dent. Pk., 40c; ; bu.. \$1.50.

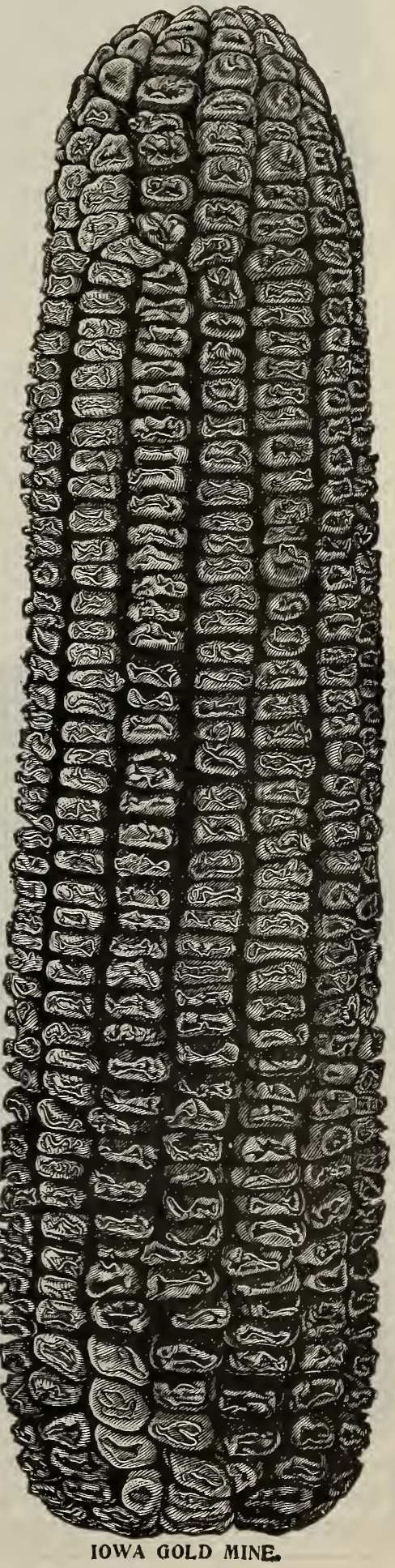




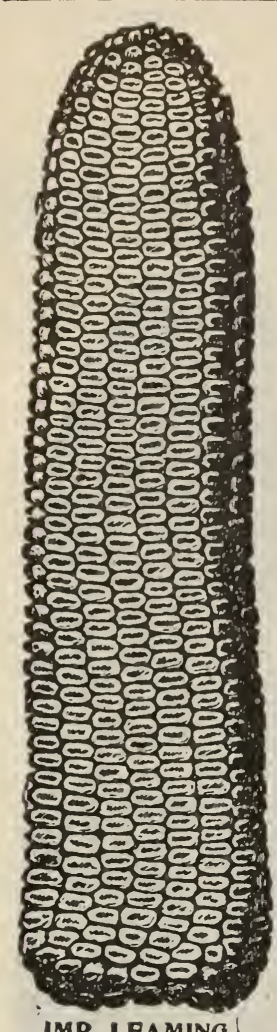

IMP LEAMING:

\section{FIELD CORN.}

Any Variety of Field Corn, Lb., 20 c., 3 lbs., 50c.; postpaid.

The Improved Leaming. The Improved Leaming Corn is a medium early yellow variety; large, slightly tapering ears, deep grain, and medium sized red cob. In favorable years there is much uniformity of both kernels and ears. Its valuable variety for feeding. It has been tested from the 38 th to the $42 d$ parallels of latitude, in the past ten years and has proved satisfactory to growers in this . It is one of the seven varieties recognized by the Illinois Experiment station, where it has been first in yield more times than any other variety in . Numerous tests at the experiment station show it high in Pk., 40c.; bu., \$1.50.

Boone County White. This excellent white variety is probably the best of that class to which Silver Mine and White Superior belong. It is the most popular white variety for Illinois, and would undoubtedly prove superior to all other white dents wherever tried. The Illinois Corn Gro

King Philip Corn. This excellent red colored Flint corn is so well known hat it needs no coecial description. Pk, 60c. bu., $\$ 1.75$

Longfellow Flint. This is an 8-roved Yellow Flint variety, the result of careful selection. The ears are from ten to fifteen inches long, one and one-half 列 of cob. Pk., 50c.; bu., \$1.75.

Canada Eight=Rowed Flint. This standard Flint corn is the earliest of all. It is a safe corn to plant where the season is short. It will mature in eighty-five days of good corn weather, Pk., 50c.; bu., \$1.75.

\section{POP-CORN.}

Golden Pop Corn. This variety, the ears of which are from 6 to 8 inches in most productive of this class of corn. Kernels large, rich color, 12-rowed.

White Rice Pop Corn. Wisconsin grown. A very fine white variety; ears 4 to 5 inches in length and 1 to $1 \frac{1}{4}$ inches in diameter. Kernel clear white, long and pointed at the top, sloping toward tip of ear. Not easy to husk, but quite prolific and especially salable among the retail grocers in Chicago. It is ery desirable for family use, popping out very large and tender.

Red Rice. An excellent popping variety of handsome appearance. Ears 4 to 6 inches long, kernel pointed Color, dark red.

White Pearl. Smooth, small-grained; ears 4 to 5 inches long, $\frac{7}{8}$ to $1 \frac{1}{8}$ inches in diameter. Good for family use or market.

Wisconsin Eight=Rowed. The standard variety for market. Is largel used by pop corn manufacturers. Grain is broad, smooth and pops out large. Yields well and can be husked rapidly.

Prices on all above varieties of Pop Corn are: Pkt., 5 c.; pt., 25c.; qt., 40c., postpaid.

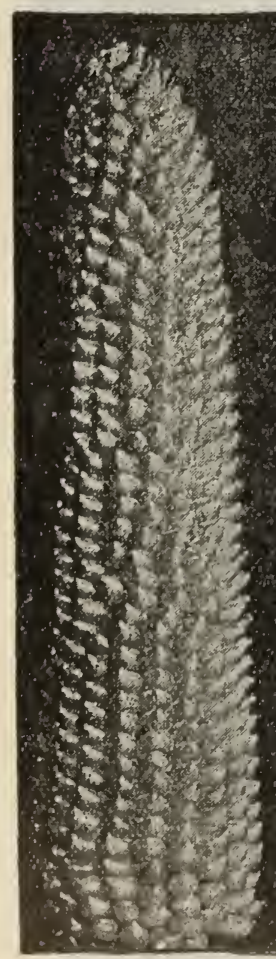

IVHITE RICE

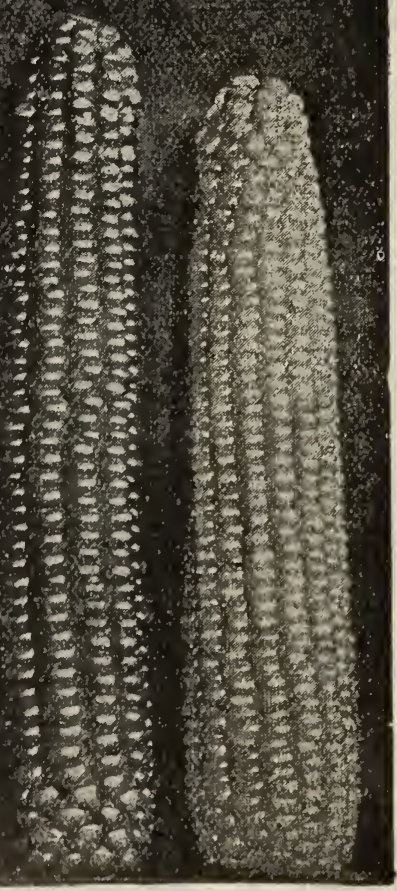
GOLDEN WHITE PEARL
POP CORN.
POP CORN. Let the boys try to raise a small patch of pop corn. There is usually a good market for it. .: :: :: ::

\section{ENSILAGE AND FODDER CORN.}

If planted in drills, which should be about three and a half feet apart, twelve to sixteen quarts per acre are required If sown broadcast, two to two and a half bushels are required to the acre.

These prices include bags and delivery to depot.

Southern Large Ensilage. This varlery gives a very heavy

yield of fodder. PK., 35c.; $\frac{1}{2}$ bu., 60 c.; bu., $\$ 1.10 ; 10$ bus.. $\$ 10.00$. Yellow Dent Ensilage varieties make splendid fodder. Pk., 35c.; bu..\$1.25.

Sweet Corn for Fodder. There is nothing better for green feed, or for curing for winter, than sweet corn. Sow in drills or

broadcast. Pk. 50c.; 1 bu., \$1.25: bu., \$2.50.

Red Cob Ensilage. A most desirable variety, adapted to all sections of the country. Pk., $40 c_{\text {. }}$; bu., $\$ 1.10$

WE GIVE SPECIAL ATTENTION to our farm Seed Department and aim to have our prices as low as possible consistent with first quality. The value of all the seeds offered in this department are sub= ject to change and those that we print are based upon the market price at this date, January 1st, 1908. As the season advances values may either advance or decline. FOR THIS REASON we shall be glad to quote market price at any time. Seeds cannot be manufactured and the value of them al= ways depends upon the quantity that has been produced and which is found to be of a quality that meets the standard suitable for planting purposes. When shortages develop prices go up; when the supply is abundant prices come down. 


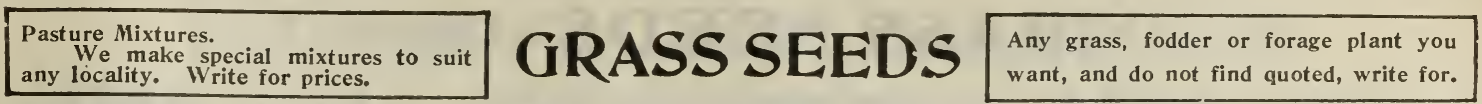
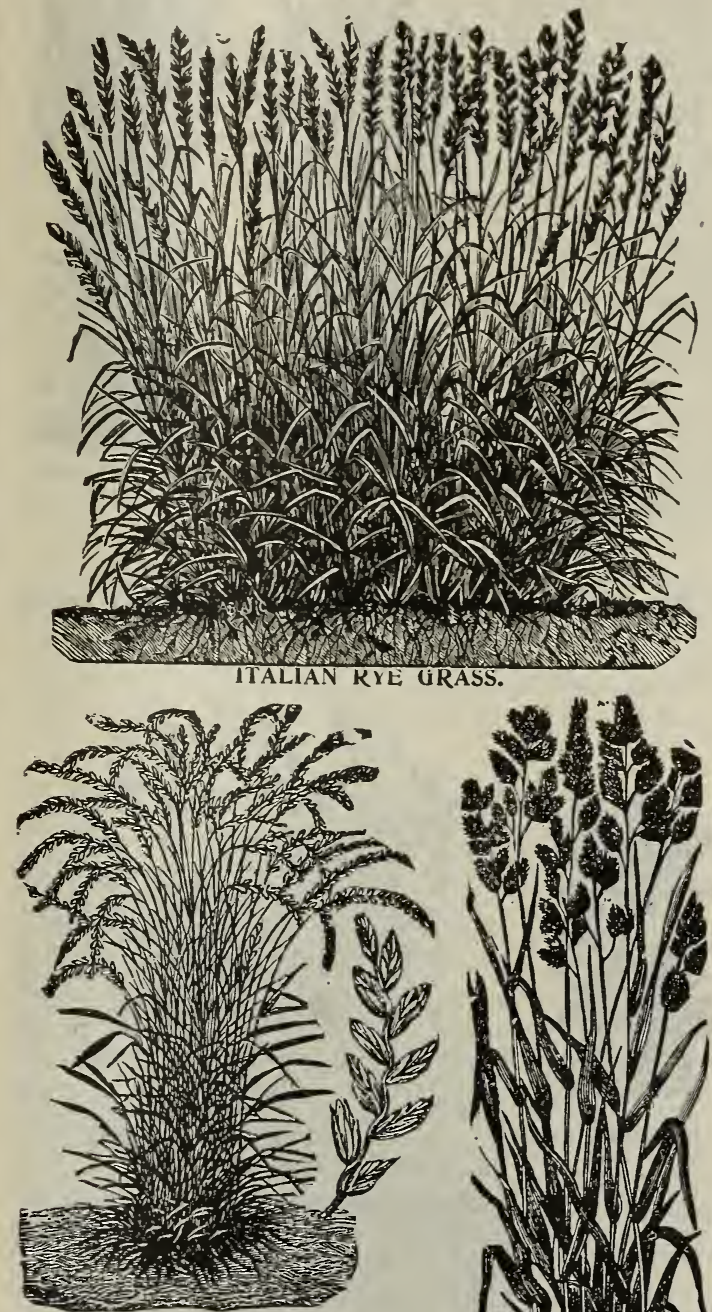

ENGLISH RYE GRASS.

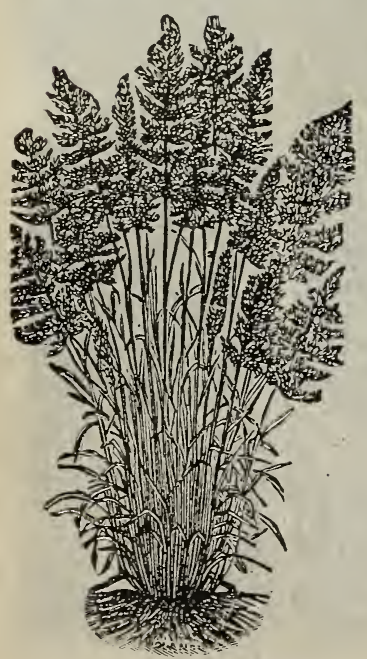

HARD FESCUE GRASS.

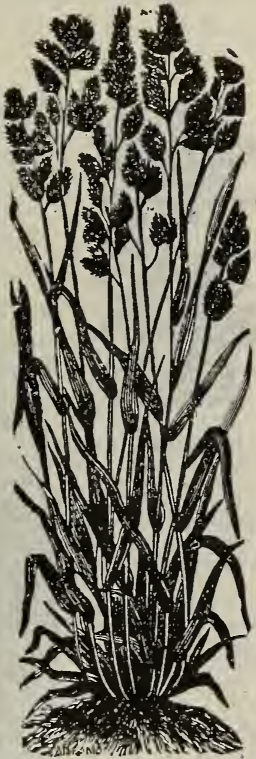

ORCHARD GRASS.

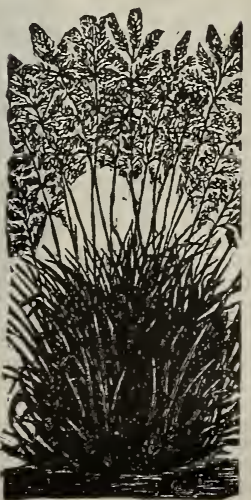

KENTUCKY BLUE GRASS
PLEASE NOTE That all Grass Seeds, Clovers, etc., are now priced by the pound and hundred pounds instead of by the bushel. Freight charges and express charges to be paid by purchaser. The prices change so frequently on Grass Seeds that our customers will be better satisfied if market price is quoted to them when they are $5 c$ aly to buy, for this reason we do not print prices.

STANDARD LIST OF NATURAL GRASSES.

Red Top. (Agrostis Vulgaris.) A valuable grass for moist soils and low lands. It is a good, permanent grass, standing our climate as well as any other, and consequently well suited to our pastures, in which it should be fed close, for if allowed to grow up 1.0 seed the cattle refuse it. On moist, rich soil it will grow 2 bushel.

Solid Seed, Best Grade. Write for Market Price.

Chaff Seed. Write for Market Price.

Timothy. (Phleum Pratense.) This is decidedly the best grass for hay, making a large return on strong, rich clay, of medium state of moisture. Write for Market Price.

It alian Rye Grass. (Lolium Italicum.) A valuable European variety, adapted to any climate and produces large and nutritive variety, adapted to any climate, and produces large

English Rye Grass. (Lolium Perenne.) A very nutritious, rapid growing variety, valuable for meadows and pastures. 24-pound bushel. Write for Market Price.

Creeping Bent. (Agrostis Stolonifera.) An excellent variety for lawns and pastures; succeeds well in damp soils. Write for Market Price.

Tall Meadow Oat Grass. (Avena Elator.) This produces an abundant supply of foliage, and is valuable for pasturing on account of its early and luxuriant growth. It is recommended for hay, and shoots up very quickly after being cut, and produces a thick crop of aftermath, which also makes it valuable as a soiling crop. Write for Market Price.

Sweet Vernal Grass. (Anthoxanthum Odoratum.) This grass yields but a moderate percentage of herbage. It is remarkable for giving out a pleasant, sweet smell during the process of drying, and it is to the presence of this grass that hay from natural meadows owes its peculiar fragrance. Permanent pastures should not be sown without a portion of this grass. Write for Market Price.

Kentucky. Blue Grass. (Poa Pratensis.) This is known in some sections as "Green Meadow Grass" and "June Grass" but some sections as "Green Meadow Grass" and "June Grass," but "June, or Wire Grass." It is the best pasture for our climate and soil, succeeding finely on hill lands and producing the most nourishing food for cattle, retains its qualities to a late period in winter, and, further south, affording abundant food throughout the winter. Sow early in spring or during the months of October and November. Fancy clean seed. Write for Market Price.

Hard Fescue. (Festuca Duriuscula.) Similar to Sheep's Fescue, but not so dense, and growing somewhat taller. This often will cover sandy soil under the shade of large trees where no other grass will grow. Is a desirable addition to lawn grass. Sow 30 pounds per acre. Write for Market Price.

Orchard Grass, or Rough Cocksfoot. (Dactylis Glomorata.) This is one of the most valuable and widely known of all pasture grasses, coming earlier in the spring and remaining later in the autumn than any other. It grows about 21 feet high, producing an immense quantity of leaves and foliage. Blooms with red clover, making with it an admirable hay. It is well adapted for sowing under trees or orchards, and very valuable either for grazing or for hay. 14-pound to bushel; 2 bushel to acre. Write for Market Price.

Meadow Fescue, or English Blue Grass. (Festuca Pratensis.) A perennial grass from 2 to 4 feet high, with flat, broad leaves. ground and succeeds well on prairie soil. This is an excellent pasture grass to take the place of wild grasses, as it yields a large amount of early and late feed. Sow about. 25 pounds per acre. Write for Market Price.

Sheep's Fescue. (Festuca Ovina.) A small, tufted, hardy grass, forming a cluster of narrow, cylindrical leaves, of value in mixture for lawns or dry soils and under shade. Sow about 35 pounds per acre. Write for Market Price.

Tall Fescue. (Festuca Elatior.) A valuable perennial grass, very productive and nutritious. It is native to moist, heavy soil where it probably does best, but it succeeds well on any good soil, wet or dry. If used alone, sov 40 pounds per acre. Write for Market Price.

Prices Vary on all Grass and Clover Seeds and on Farm Grains. For this reason our customers will find it more satisfactory to write for the latest market prices before buying. 


\section{GRASS SEEDS-continued.}

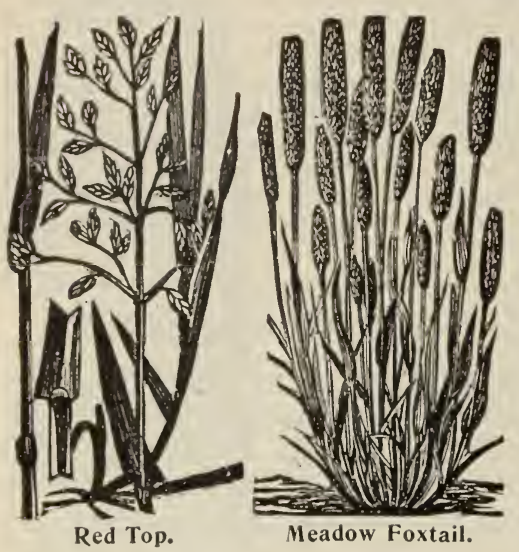

GRASS AND CLOVER SEED prices constantly change, and it is always best to write for latest market prices previous to ordering.
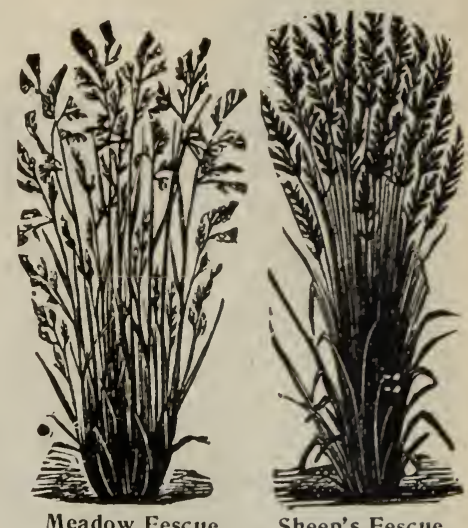

Sheep's Fescue.

Meadow Fescue.
Wood Meadow Grass (Poa Nemoralis.) strong growing, hardy grass, well

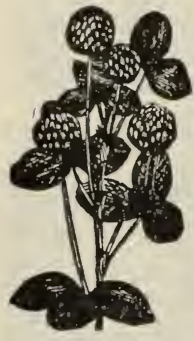

Alsike, or Swedish Clover.

\section{CLOVER SEEDS.}

Medium Red or June (Trifolium Pratense). This is by far the most important of all varieties, for the practical purpose of agriculture. Sow in spring or fall, and when no other grasses are used, at the rate of eight or ten pounds per acre, more being required on old stiff soils than on new and lighter ones. Sixty pounds per bushel. Write for Market Price.

Mammoth or Large Red (Trifolium Pratense). It grows five or six feet high, its stalks are so coarse and large that stock will eat only the leaves. By it judicious use lands which have been exhausted may be reclaimed as it will grow where the acre. 60 lbs. per bushel. Write for Market Price.

White Dutch (Trifolium Ripens). A small, creeping, spreading, perennia variety, valuable for pasture and lawns. It accommodates itself to a variety of soils, but prefers moist ground. In conjunction with Blue Grass it forms the most the food for sheep or cows. Sow in spring at the rate of six pounds per acre, Market Price.

Alsike or Swedish (Trifolium Hybridum). This valuable variety is fast gaining great popularity. It is the most hearty of all the clovers; perennial. On rich moist soils it yields an enormous quantity of hay or pasture, and nay be cut severa times in a season, but its greatest value is for sowing with other clovers and grasses, as it forms a thick bottom and greatly increases the yield of hay and cattle prefer it to other forage. Sow in spring or fall at the rate of six p pur

used alone. 60 pounds per bushel. Write for Market Price.

Alfalfa or Lucerne Medicago Sativa). One of the best varieties, succeeding in almost every situation and hearing heavy crops of forage. Will bear cutting three or four times during the season. For bringing up poor land it is the best of the clovers, as it not only prodnces large masses of foliage, but forces its roots down fully three feet into the earth. Sow early in spring to secure a good stani

Crimson or Scarlet Clover. It can be seeded at any time from June to October, rate of fifteen to twenty pounds per acre and makes the earliest possible spring pasture, blooming the latter part of April or May aud for feeding as liay before coming into full bloom. If sown with Italian Rye Gras (lite same time, it yield luxuriant and nutritious

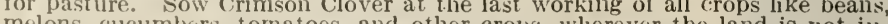

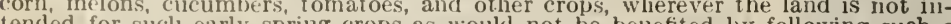
seeding protecting the giound throuy theed for only all and winter months, if only for Market Price, 


\section{LEONARD'S GRASS MIXTURES}

The "Leonard" Lawn Grass. For quickly producing a permanent, thick and velvety sward of grass, this brand of Lawn Grass cannot be excelled. It is the best mixture of grasses we sell for lawn-making, and will give satisfaction wherever sown. Lb., 35c.; 3 lbs., $\$ 1.00$, postpaid. Sold over our counters or sent by express or freight at buyer's expense, lb., 25c.; 5 lbs., $\$ 1.25 ; 10 \mathrm{lbs}$., $\$ 2.50 ; 100 \mathrm{lbs}$., $\$ 25.00$.

Chicago Parks Mixture. This popular Mixture in all cases gives good satisfaction. A pound of seed will sow about twenty feet square. Price, per lb., 30c.; $3 \frac{1}{2}$ lbs., \$1.00, postpaid. Sold over our counters or sent by express or freight at buyer's expense, 1b., 22c.; 6 lbs., $\$ 1,30 ; 10$ lbs., $\$ 2.00 ; 100$ lbs., $\$ 20.00$.

Evergreen Lawn Grass. This Mixture contains many grasses which are not in the Chicago Parks Lawn Grass, and although the latter is well and favorably known this will be found a much better one.

With slight variations, it can be prepared to suit light, medium or heavy soil, and when wanted for Croquet Ground or Tennis Court those grasses which produce a firm turf can be used more liberally. Lb., 35 c.; 3 lbs., $\$ 1.00$, postpaid. Sold over our counters or sent by express or freight at buyer's expense, 1b., 25c.; 5 lbs., $\$ 1.25 ; 10$ lbs., $\$ 2.50 ; 100 \mathrm{lbs}$., $\$ 25.00$,

Tcrrace Lawn Grass, This is a special blend for Terrace and Embankments. Lb., 35c; 3 lbs., \$1.00; postpaid, By Express or freight, 5 lbs., $\$ 1,50 ; 10 \mathrm{lbs}$, $\$ 2.75 ; 100$ libs., $\$ 26.50$,
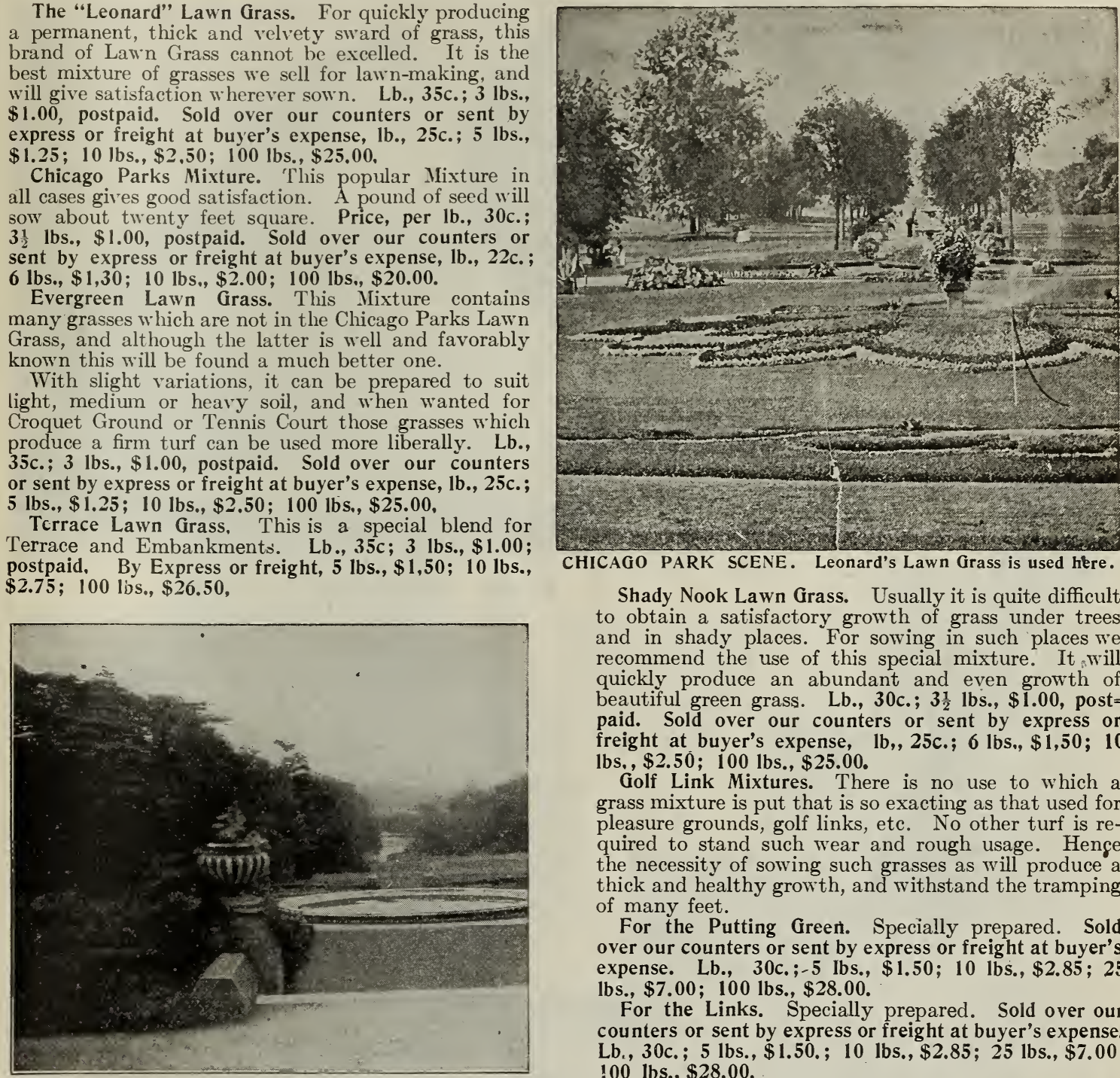

CHICAGO PARK SCENE. Leonard's Lawn Grass is used here.

Shady Nook Lawn Grass. Usually it is quite difficult to obtain a satisfactory growth of grass under trees and in shady places. For sowing in such places we recommend the use of this special mixture. It will quickly produce an abundant and even growth of beautiful green grass. Lb., 30c.; $3 \frac{1}{2} \mathrm{lbs}$., $\$ 1.00$, post $=$ paid. Sold over our counters or sent by express or freight at buyer's expense, lb,, 25c.; 6 lbs., $\$ 1,50 ; 10$ lbs., $\$ 2.50 ; 100$ lbs., $\$ 25.00$.

Golf Link Mixtures. There is no use to which a grass mixture is put that is so exacting as that used for pleasure grounds, golf links, etc. No other turf is required to stand such wear and rough usage. Henge the necessity of sowing such grasses as will produce a thick and healthy growth, and withstand the tramping of many feet.

For the Putting Green. Specially prepared. Sold over our counters or sent by express or freight at buyer's expense. Lb., 30c.;-5 lbs., \$1.50; 10 lbs., \$2.85; 25 lbs., $\$ 7.00 ; 100$ lbs., $\$ 28.00$.

For the Links. Specially prepared. Sold over our counters or sent by express or freight at buyer's expense. Lb., 30c.; 5 lbs., \$1.50.; 10 lbs., $\$ 2.85 ; 25$ lbs., $\$ 7.00$ 100 lbs., $\$ 28.00$.

TERRACE LAWN GRASS.

\section{LAWN FERTILIZERS}

Leonard's Lawn Fertilizer. Quick acting and long lasting. Guaranteed analysis: Ammonia, 4 to 5 per cent; available phosphoric acid, 7 to 9 per cent; total phosphoric acid, 8 to 11 per cent; actual potash, 7 to 9 per cent. This is positively the best article on the market for use as a complete manure for all purposes. It is the best lawn fertilizer ever prepared. Note the large amount of actual potash in this brand. 10 =lb. package, 50c.; 25 lbs., $\$ 1.00$; bag of $100 \mathrm{lbs}$., $\$ 2.00 ; 200 \mathrm{lbs}$., $\$ 3.50$; ton, $\$ 33.00$.

Blatchford's Plant Grower Lawn Fertilizer and Land Renovator. This splendid fertilizer is composed of pure nitrate of soda, sulphate of potash, Peruvian guano, sulphate of ammonia, bone meal and gypsum. It is excellent for lawns, for indoor plants, vegetable crops and for all purposes for which a fertilizer is needed. $10 \mathrm{lb}$. bag, 50c.; $20 \mathrm{lb}$. bag, $\$ 1.00 ; 100 \mathrm{lb}$. bag, $\$ 3.00$. Special quotations on larger lots.

Ground Raw Bone. Guaranteed analysis: Ammonia, 4 to 5 per cent; bone phosphate, 45 to 55 per cent; equal to phosphoric acid, 21 to 25 per cent. This is a pure ground raw bone - no rock is put in to cheapen it. These goods also will analyze nearer the highest limit of our guarantee. $10 \mathrm{lbs}$., $50 \mathrm{c}_{\wedge} ; 25 \mathrm{lbs} ., \$ 1.00$; bag of 100 lbs., $\$ 1.90 ; 200 \mathrm{lbs} ., \$ 3.00$; ton, $\$ 33.00$.

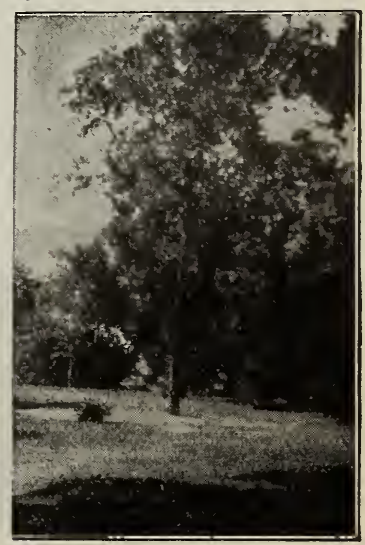

SHADY NOOK. 


\section{GLADIOLUS SPECIALTIES}

\section{THOMPSON'S HYBRIDS}

A few of the finest named Gladiolus that could be procured were put together and crossbred over 11 years. Then special work in handling the bulbs, and the result shows in the engraving, better than can be expressed in words. The bulbs are round and exceptionally strong, with the finest flowers imaginable. Each, 10c.; Dozen, $\$ 1.00$.
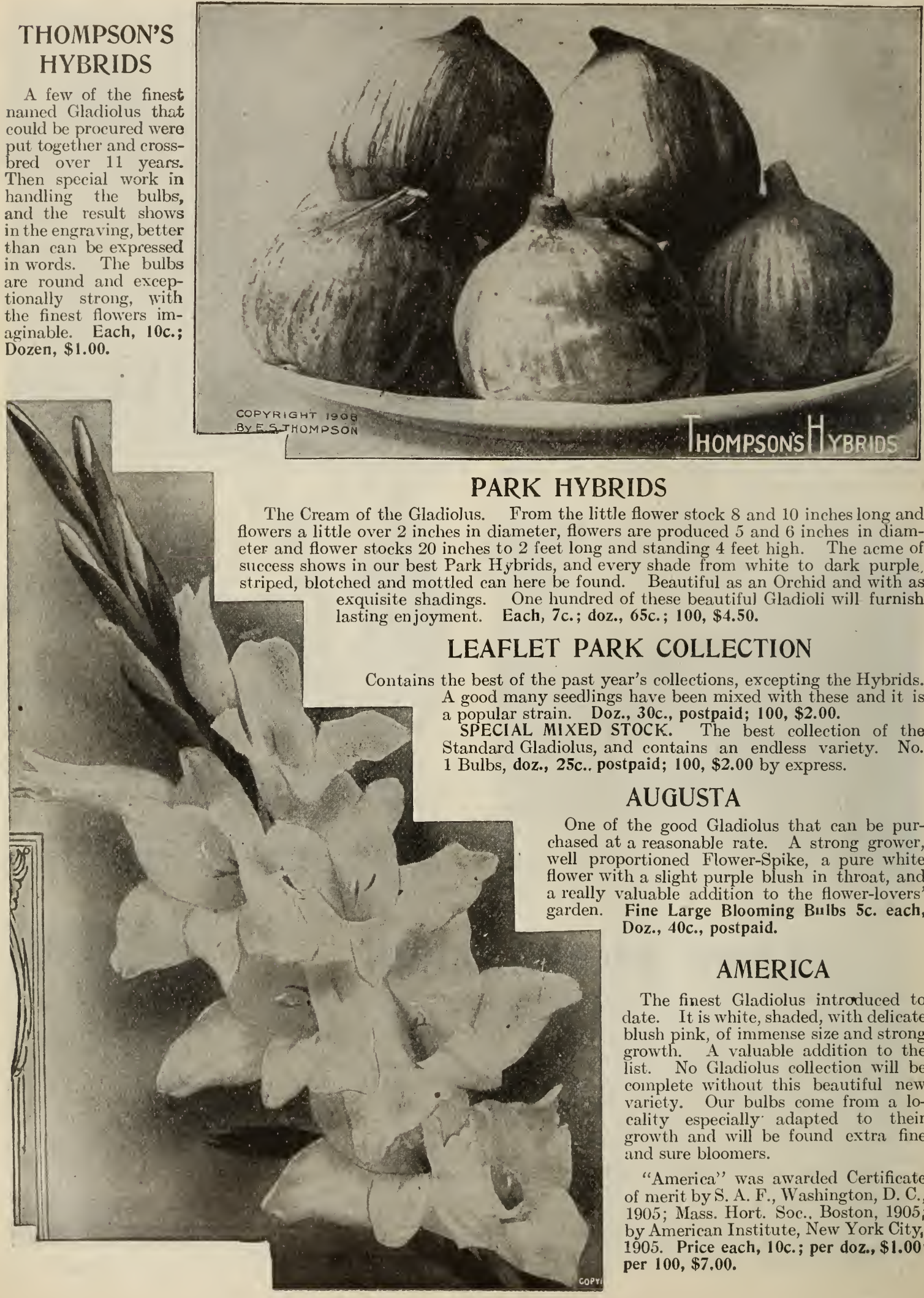

\section{PARK HYBRIDS} are produced 5 and 6 inches in diamer and flower stocks 20 inches to 2 feet long and standing 4 feet high. The acme of success shows in our best Park Hybrids, and every shade from white to dark purple striped, blotched and mottled can here be found. Beautiful as an Orchid and with as exquisite shadings. One hundred of these beautiful Gladioli will furnish

\section{LEAFLET PARK COLLECTION}

pear's collections, excepting the Hybrids. good many seedlings have been mixed with these and it is popular strain. Doz., 30c., postpaid; $100, \$ 2.00$.

MIXED STOCK. The best collection of the thiolus, and contains an endless variety. No. 1 Bulbs, doz., 25c.. postpaid; $100, \$ 2.00$ by express.

\section{AUGUSTA}

One of the good Gladiolus that can be purchased at a reasonable rate. A strong grower, proportioned Flower-Spike, a pure white er with a slight purple blush in throat, and a really valuable addition to the flower-lovers' garden. Fine Large Blooming Bulbs 5c. each, Doz., 40c., postpaid.

\section{AMERICA}

The finest Gladiolus introduced to date. It is white, shaded, with delicate blush pink, of immense size and strong growth. A valuable addition to the list. No Gladiolus collection will be complete without this beautiful new variety. Our bulbs come from a locality especially adapted to their growth and will be found extra fine and sure bloomers.

"America" was awarded Certificate of merit by S. A. F., Washington, D. C., 1905; Mass. Hort. Soc.. Boston, 1905; by American Institute, New York City, 1905 . Price each, $10 \mathrm{c}$.; per doz., $\$ 1.00$; per $100, \$ 7.00$. 


\section{DAHLIA SPECIALTIES}

These beautiful sorts are arranged to provide a variety in both flower and plant, no two are in any way similar and all are desirable for the Home Garden. Chicago is one of the grandest flowers of recent introduction and will surprise everyone with its richness of coloring and magnificent growth although of somewhat dwarfish habit.

The two Peony Flowered varieties are specially good in their class, being also different in both form of growth, and color and form of flower.

\section{DEEP RED PEONY.}

A fine 4 inch flower, on stems 18 inches long, almost double, a strong grower, reaching 5 feet in height. Sometimes verges to magenta in color.

\section{ART YELLOW.}

Is one of the best of the new Peony Flowered varieties that have gained so rapidly in popular favor during the last two years; of a clear, lemon yellow, and with beautiful incased petals at the center. The plant grows bush and makes a neat picture in the garden or on the lawn.

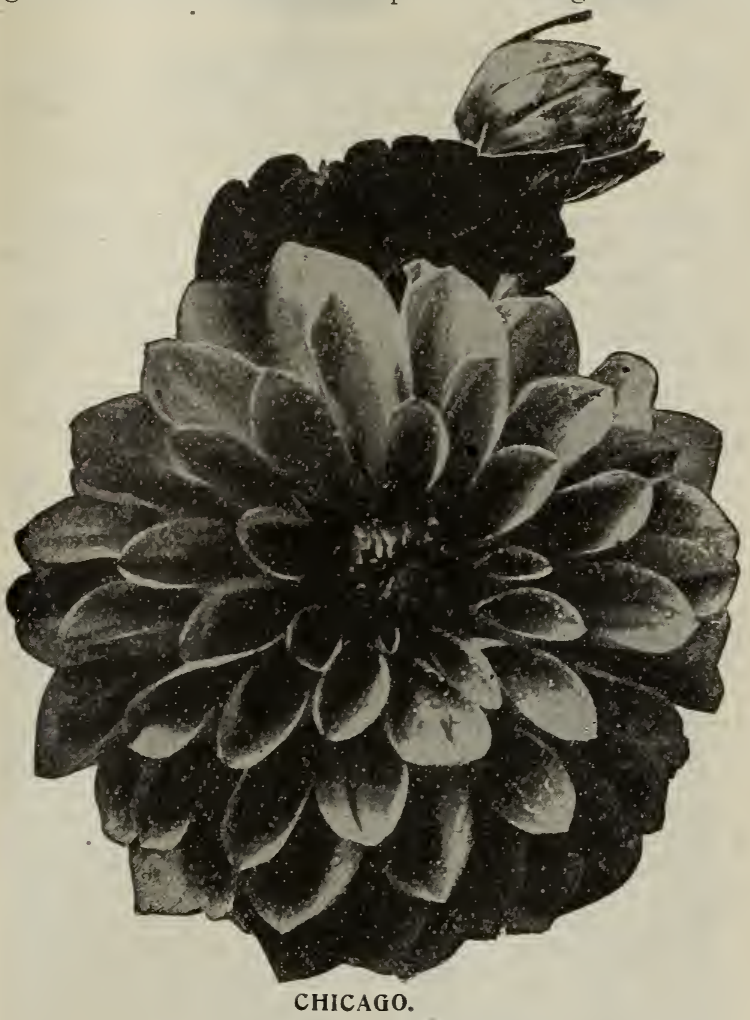

\section{BLUSH PINK}

Flower from 3 to $3 \frac{1}{2}$ inches in diameter. Cream center, outer petals a suffused pink blush. Very much resembles Nymphaea. A trifle smaller, but with longer stems, making it a good flower for cutting.

\section{BLUE BELL}

Bright bluish magenta flower, grows from 2 to 3 feet high. Flowers $1 \frac{1}{2}$ to 2 inches Pompon. The best of its color yet introduced. Fine foliage, abundant flowers, forms a compact bushy plant that will not easily blow down.

Price of the SET of 6 NEW DAHLIAS put up in a Neat Box, each Dahlia in a sack by itself, with full description and directions for culture, $\$ 1.25$

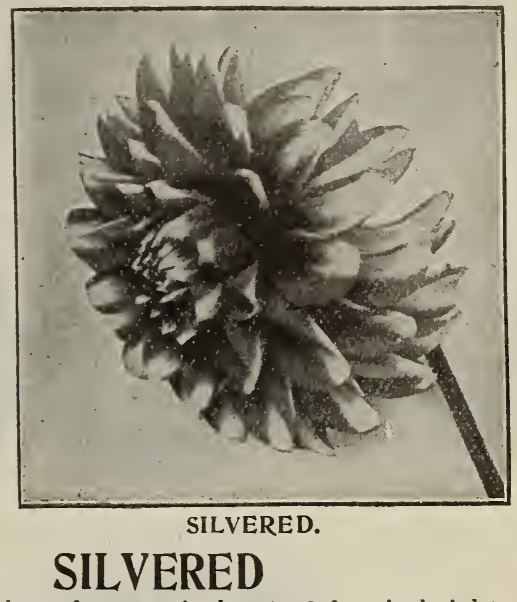

A bushy plant from 20 inches to 2 feet in height; bright glossy foliage, pleasing yellow flower; petals neatly tipped with white, from 2 to 3 inches in diameter, and a perfect double flower. They will please all lovers of flowers.

\section{CHICAG0}

Is the grandest flower for the garden of recent introduction. Like its namesake it is strong, robust, aggressive in growth, cannot be blown down, and in color its richness cannot easily be described. From intense Crimson, shading to light Salmon or Mauve, with the beautiful blendings of Dark Orange, make it at once a flower never to be forgotten.

The flower from which the engraving was taken was beautifully perfect and $7 \frac{1}{4}$ inches in diameter.

As will be noticed at the bottom of page, we make a low price for the whole set of six. Every one should have the full set. If however, any particular one is wanted we quote.

DEEP RED PEONY................. $\$ 0.30$ Each

ART YELLOW ................ " .30 "

SILVERED $\ldots \ldots \ldots \ldots \ldots \ldots \ldots \ldots \ldots \ldots \ldots$ " .50 "

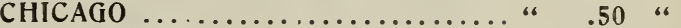

BLUSH PINK ................ "

BLUE BELL ................. $\quad .30$ "

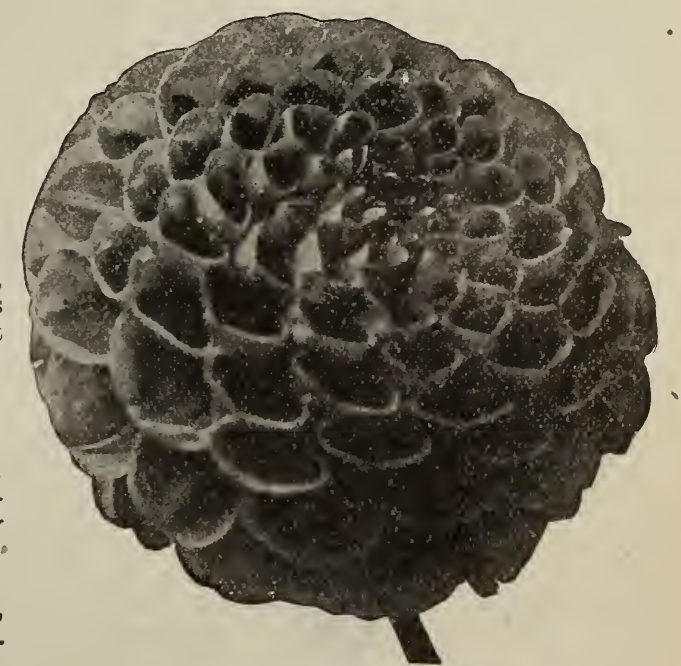

BLUE BELL. 

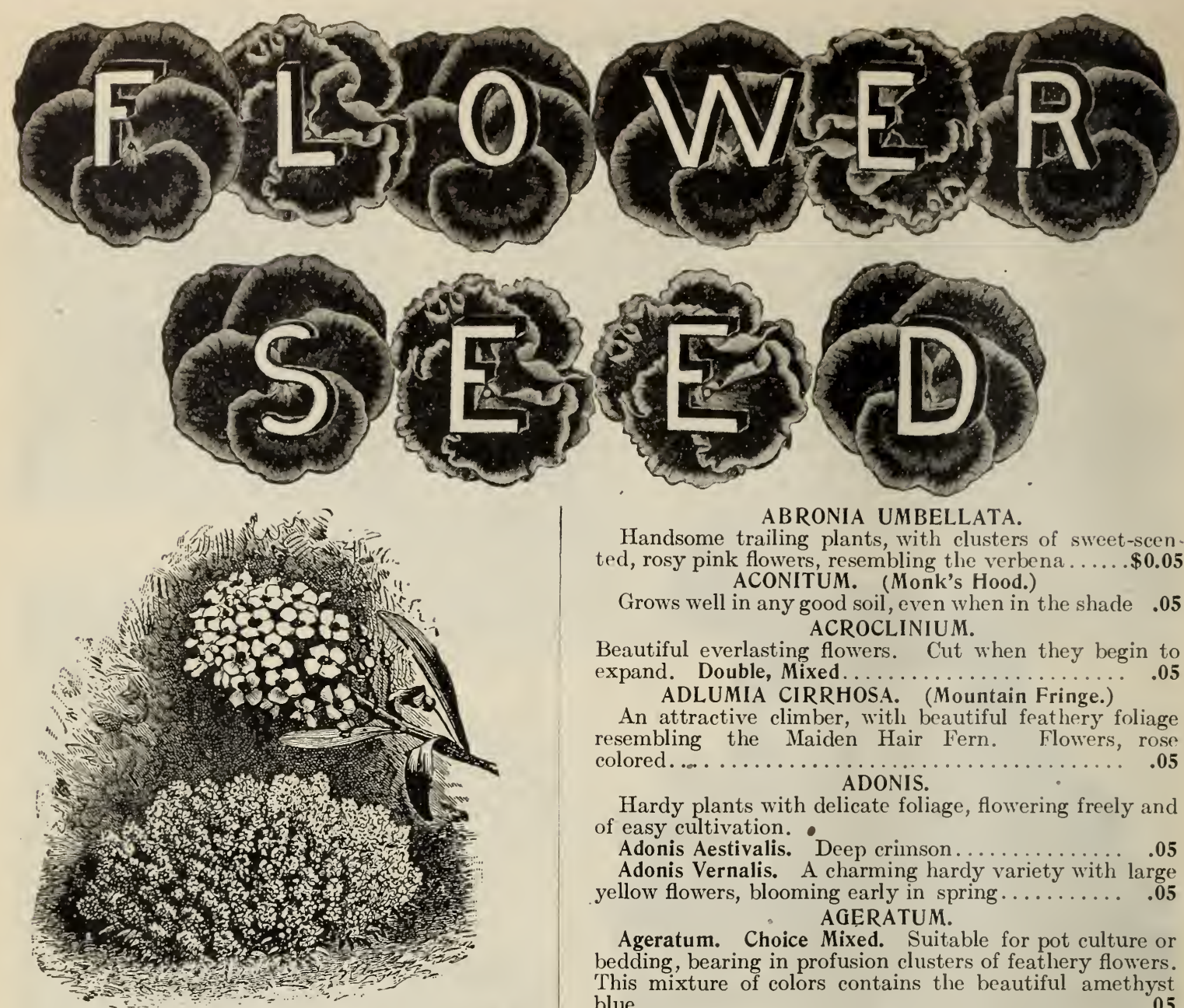

ABRONIA UMBELLATA.

Handsome trailing plants, with clusters of sweet-scented, rosy pink flowers, resembling the verbena .....\$0.05 ACONITUM. (Monk's Hood.)

Grows well in any good soil, even when in the shade .05 ACROCLINIUM.

Beautiful everlasting flowers. Cut when they begin to expand. Double, Mixed..................05 ADLUMIA CIRRHOSA. (Mountain Fringe.)

An attractive climber, with beautiful feathery foliage resembling the Maiden Hair Fern. Flowers, rose colored....................

$$
\text { ADONIS. }
$$

Hardy plants with delicate foliage, flowering freely and of easy cultivation.

Adonis Aestivalis. Deep crimson.......... .05

Adonis Vernalis. A charming hardy variety with large yellow flowers, blooming early in spring........ .05

$$
\text { AGERATUM. }
$$

Ageratum. Choice Mixed. Suitable for pot culture or bedding, bearing in profusion clusters of feathery flowers. This mixture of colors contains the beautiful amethyst blue.............................. AMMOBIUM. (Everlasting Flower.)

ALYSSUM-LITTLE GEM.

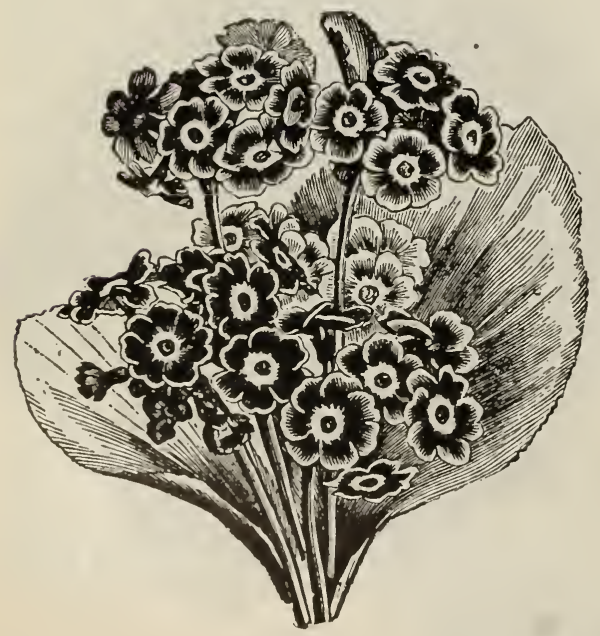

Ammobium Alatum Grandiflorum. Large white-flowering variety.....................

Free flowering plants for beds, edging, etc. Useful for bouquets because of their delicate fragrance.

Alyssum Sweet, Little Gem. Dwarf and compact, with plants a mass of white from spring until frost.... .05

Alyssum, Sweet. White. Per 0z. 25c........ .05

Alyssum Saxatile. (Hardy Alyssum.) Beautiful springblooming variety, with flowers of a deep pure yellow $\mathbf{. 0 5}$ AMARANTHUS.

Ornamental foliage plants. 'They are most brilliant on poor soil.

Amaranthus Tricolor Splendens. Very brilliant... .05

Amaranthus Salicifolius. The leaves change in color from a bronzy green to a brilliant scarlet as the plant attains age.

\section{ARABIS ALPENA.}

Hardy, herbaceous plant, with pure white flowers: blooms very early in the spring; fine for borders, desirable for cemeteries.........................

Handsome bushy annual two ft. high, flowering abundantly from early summer until late autumn. The beautiful daisy-like flowers, $2 \frac{1}{2}$ in. across, are white, shaded with pale lilac and zoned with yellow...... .10 AURICULA.

Tender perennials. Also called French Cowslips. An AURICULA. old garden favorite.

Alpine. Most hardy. Int............... 10 


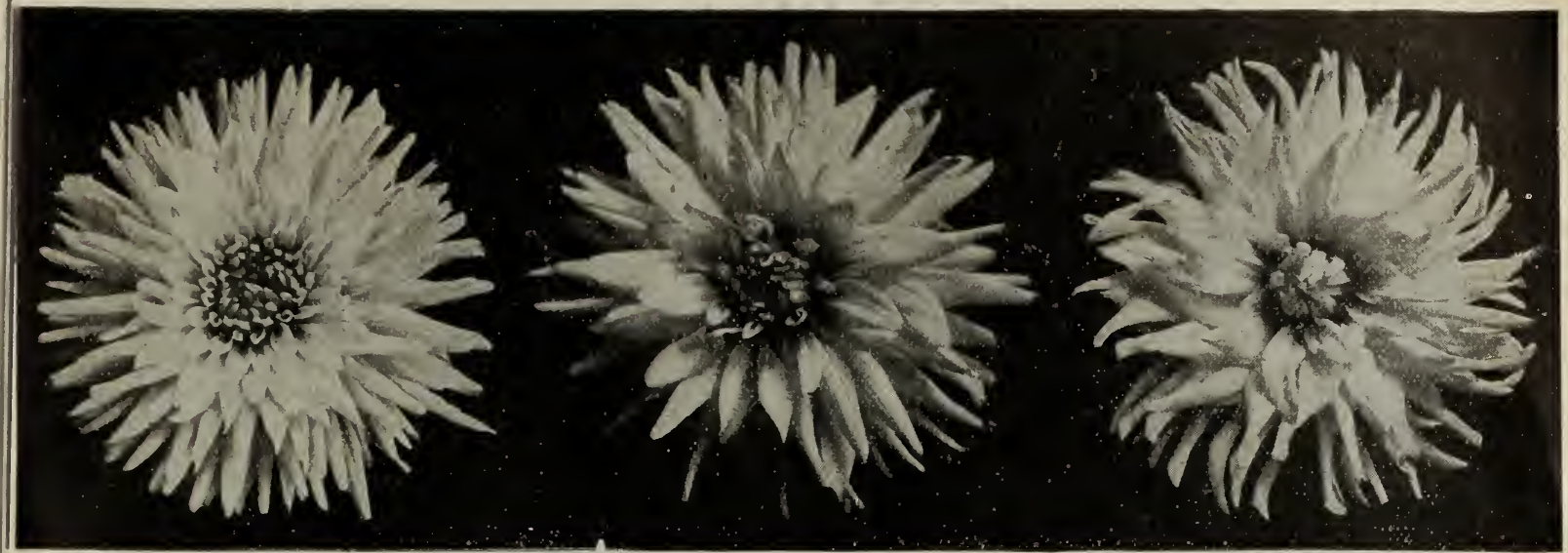

\section{SEMPLE'S GIANT LATE ASTITRS
BRANCHING ALNTIS}

A superior strain of American-grown Asters which have been brought to a high degree of excellence. Of branching habit, producing many perfect flowers four inches or more in diameter on long stems; flowers are very double and of the purest colors. The strong, branching plants grow about $2 \frac{1}{2}$ feet high. The flowers have very graceful and wavy petals, which give to the flowers that elegant Japanese Chrysanthemum effect which is so greatly admired. Immense quantities of these fine Asters are grown for the florists' cut-flower trade Its large beautiful flowers, free-flowering habit, and long stems, make it a prime favorite with large growers of Asters.

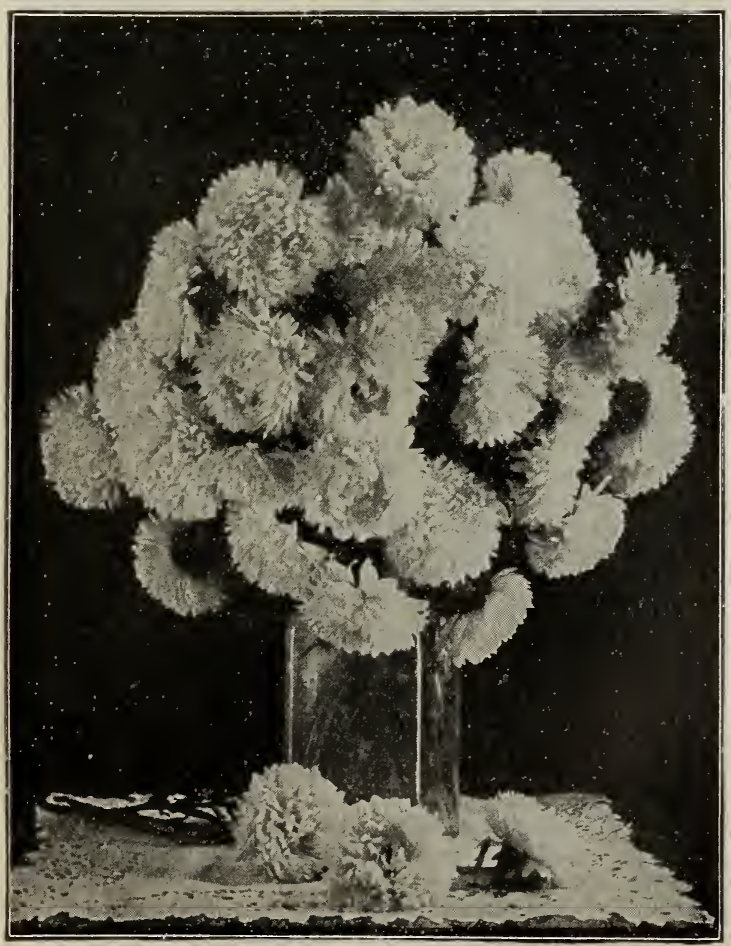

ASTER VICTORIA
Semple's Giant Finest Mixed Colors--All shades and colors. Pkt., 10c.; $\frac{1}{8}=0 z_{.}, 20 c . ; \frac{1}{1}=0 z ., 35 c$.; 0z., $\$ 1.00$. Semple's Giant Lavender ..............Pkt., 10c. Semple's Giant Royal Purple............. Semple's Giant Pure White........... Pkt, 10c. Semple's Giant Crimson'................ Semple's Giant Shell Pink.............. Pkt," 10c.

\section{GIANT COMET ASTERS}

A very large-flowering variety of Asters similar to the Ostrich Plume described elsewhere. The elegant flowers of enormous size are certainly well worthy of the admiration accorded them. It is an ideal variety for cutflowers, being not only a most profuse bloomer, but each individual flower is borne on a stiff stem and resembles an exquisitely curled and twisted Japanese Chrysanthemum. Height 2 to $2 \frac{1}{2}$ feet.

GIANT COMET, Snow White-Grand; pure white, flowers of immense size and wonderful perfection

GIANT COMET, The Bride-Elegant form and delicate coloring. Color, at first, white, changing to a lovely pink, finally to a beautiful rose. For cut-flowers it is one of the best................... 10 c.

GIANT COMET, Mixed Colors-A superb mixture which includes all the best colors and shades in this class........................ 10c.; $\frac{1}{8}$ 0z., 25c. Giant Comet Crimson, pkt, 10c. Giant Comet Rose Pink, pkt, 10c. Giant Comet Light Blue, pkt, 10c. Giant Comet Dark Blue, pkt, $10 \mathrm{c}$.

\section{VICTORIA ASTERS}

Of all the large flowered Asters none surpass this truly magnificent class. The plants themselves are strong growers, and produce profusely the most beautiful imbricated flowers. The stems being long and strong, none are finer for cut flowers. The Victoria Asters resemble Truffauts Peony Flowered Asters very closely except that the petals recurve to the edge of the flower instead of incurving to the center. Superb colors; elegant sort. 2 feet.

VICTORIA ASTERS, Mixed Colors-Very fine. Pkt., 10c.; $\frac{1}{8}=0 \mathrm{z}$., 35c.; $\frac{1}{4}=0 \mathrm{z}$., $60 \mathrm{c}$.

Separate Colors-Crimson, Carmine Rose, Dark Blue, Light Blue, Pure White. Each color, pkt., 10c.

DWARF VICTORIA ASTERS-Perfect -flowers of large size, produced profusely. 10 inches high. Effective in beds and borders. Choice mixed, pkt., $10 \mathrm{c}$. 


\section{ASTERS-Continued}

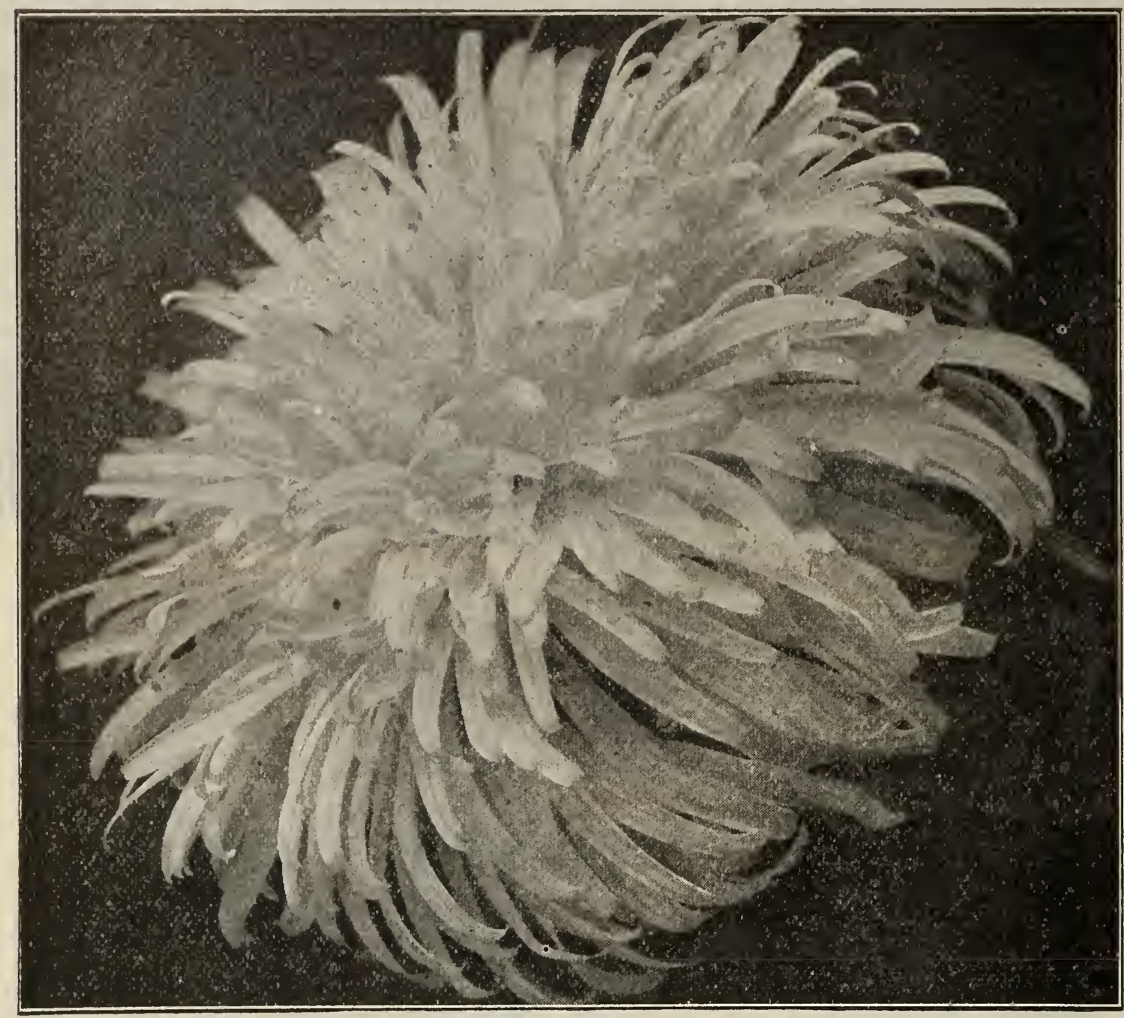

GIANT OSTRICH PLUME ASTER.
GIANT OSTRICH PLUME ASTERS.

A very large-flowering class whose blooms are of the most perfect sliape; splendid for cut-flowers. Resembles the Giant Comet Asters, as it has the same curled and twisted petals; however, the petals are longer, and the whole flower larger. Individual blooms often measure 4 to 6 inches in diameter. Our illustration on this page which is much reduced ( $\frac{1}{2}$ natural size), will give you a fair idea of its elegance. Plants of luxurious branching habit, with flowers on long slender stems. Height 2 feet.

Giant Ostrich Plume, Mixed Colors-Embraces all the desirable colors in splendid mixture. Pkt., 10c.; $\frac{1}{8} \mathrm{oz}, 25 \mathrm{c}$. ; $\frac{1}{4} \mathrm{Oz}$., 45c.

Ostrich Plu me Snow White, pkt........ .10

Ostrich Plume Rose Pink, pkt....... $\quad .10$ Ostrich Plume Light Yellow, pkt........ 10 Ostrich Plume Azure Blue, pkt....... . 10

Ostrich Plume Lavender, pkt............. .10

Ostrich Plume Dark Blue, pkt............ .10

Ostrich Plume Crimson, pkt............. .10

Betteridge's Quilled. The finest form of asters, having quilled petals. Finest Mixed. $2 \frac{1}{2} \mathrm{ft}$. desired this is very popular, being of good size

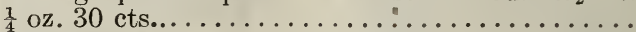

Cocardeau, or Crown. Center of each flower having a white center with a wide margin of some brilliant colors. Finest Mixed. $2 \frac{1}{2} \mathrm{ft} . \frac{1}{4} \mathrm{oz} . \$ 1.25$

Daybreak. Large, very double flowers of a beautiful shell pink color. $2 \frac{1}{2} \mathrm{ft}$. $\frac{1}{4} \mathrm{oz} . \$ 1.25 \ldots$

Purity. Large, very double flowers, Pure white. $2 \frac{1}{2} \mathrm{ft} . \quad \frac{1}{4} \mathrm{oz} . \$ 1.00 \ldots \ldots \ldots \ldots \ldots \ldots$

General Jacqueminot. Color very rich crimson, flowers large, very double. $2 \frac{1}{2} \mathrm{ft} . \quad \frac{1}{4} \mathrm{oz} . \$ 1.00$.

Snowball, or Princess. When a white aster is and a profuse bloomer. $2 \frac{1}{2} \mathrm{ft} . \quad \frac{1}{4} \mathrm{Oz} . \$ 1.00 \ldots \ldots$

Dwarf, Finest Mixed. The dwarf varieties are becoming more popular, as the flowers are nearly as large as the tall growing varieties and equally as good form. $1 \mathrm{ft} . \quad \frac{1}{8} \mathrm{oz} .50 \mathrm{cts} . \ldots \ldots \ldots \ldots . .05$

Perfection Mixture. In this we have endeavored to make as perfect a selection for variety as possible, including all the finest varieties of the large flowering asters. The colors include every shade known to asters. A single packet should contain a choice selection of the most popular asters in cultivation. $2 \frac{1}{2}$ ft............... oz. $\$ 4.00 ; \frac{1}{8}$ oz. 60 cts. .05 Superfine Mixed. $2 \frac{1}{2} \mathrm{ft} \ldots \ldots \ldots \ldots \ldots \frac{1}{4} \mathrm{oz} . \$ 1.00 \quad .05$

Aster, Christmas Tree. On account of its branching habit, this Aster is the most striking among the many varieties. The branches are horizontal; the plants attain a height of 20 inches and measure 24 to 28 inches in diameter at the base. Early and very profuse flowering. This effective aster is beautiful as a single plant in beds, or for pot culture.

Finest Mixed, $21 \mathrm{ft}$ .oz. $\$ 1.00 \quad .10$

Dark Blue $2 \frac{1}{2} \mathrm{ft}$

Light Blue. $2 \frac{1}{2} \mathrm{ft}$

Rose. $2 \frac{1}{2} \mathrm{ft} .$. .

oz. $1.00 \quad .10$

$\mathrm{oz} \quad 1.00 \quad .10$

oz. $1.00 \quad .10$

oz. $\quad 1.00 \quad .10$

Peach Blossom: $21 \mathrm{ft} \ldots \ldots \ldots \ldots \ldots \ldots$. . . $1.00 \quad .10$

White: $2 \frac{1}{2} \mathrm{ft}$.

oz. 1.00 beds, or for pot culture............................... 


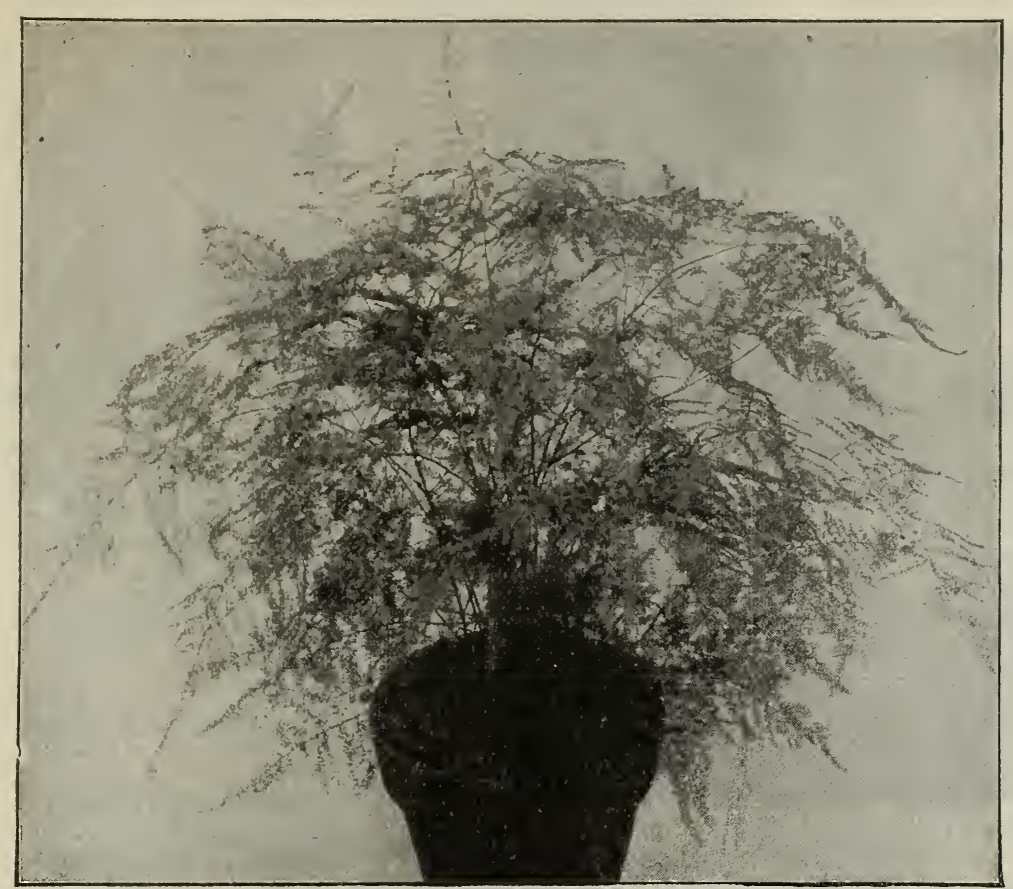

ASPARAGUS PLUMOSUS

ROBUSTUS.

The fronds often attain a length of $9 \mathrm{ft}$., are very dark green and finely feathered. Being of such vigorous growth it yields more sprays for cutting than any other varietyand is easily propagated .20

ANTIRRHINUM

(Snap Dragon).

Are extensively grown under glass for cutting during the winter. The pure white and yellow varieties are nostly used. If sown under glass in February or March they will commence to bloom in July and will continue until late in the autumn. The long spikes produce gorgeously colored flowers. Excellent for cutting. Half-hardy biennial. Tall Finest Mixed, 5c. Dwarf Finest Mixed, 5c.

\section{OUR FLOWER SEEDS} are the product of the best specialists in their respective classes. The $\mathrm{mixt}$ ure $\mathrm{s}$ contain the various colors blended in proper propor= tion.

\section{ASPARAGUS PLUMOSUS}

\section{CHINA ASTERS}

Aster. Chinese Single. These are exceedingly showy and excellent in cutting for vase decorations. The large, brilliant, daisy-like flowers with yellow centers are produced in profusion. Hardy perennial.

Finest Mixed $2 \mathrm{ft} \ldots \ldots \ldots \ldots$ Pkt.

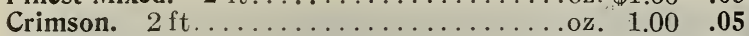

Dark Blue. $2 \mathrm{ft} \ldots \ldots \ldots \ldots \ldots \ldots \ldots \ldots \ldots$. $1.00 \quad \mathbf{. 0 5}$

Light Blue. $2 \mathrm{ft} \ldots \ldots \ldots \ldots \ldots \ldots \ldots \ldots \ldots$ oz. $1.00 \quad .05$

Rose. $2 \mathrm{ft} \ldots \ldots \ldots \ldots \ldots \ldots \ldots \ldots \ldots \ldots$. $1.00 \quad .05$

White. $2 \mathrm{ft} \ldots \ldots \ldots \ldots \ldots \ldots \ldots \ldots \ldots . . \ldots$. $1.00 \quad .05$

\section{AQUILECIIA (Columbine).}

One of the most popular perennials, easiest of cultivation. Blooms profusely from May to August; very desirable for herbaceous borders and groups among shrubs. Moist soil preferable. Hardy perennial. Finest Mixed, 5c.

ARISTOLOCHIA. (Dutchman's Pipe.)

A beautiful hardy climber. Leaves large and luxuriant; flowers brownish yellow, in shape resembling a pipe, 5 c.

\section{BALLOON VINE.}

Ornamental climbing plant, remarkable for an inflated membraneous capsule from which it derives its name, 5c.

BRACHYCOME. (Swan River Daisy.)

Produce an abundance of daisy-like flowers, about 1 foot high. Fine for edgings, beds or rustic baskets. Blue, Pkt., 5c. White, Pkt., 5c. Mixed, Pkt., 5c.

\section{BALSAMS. (Lady Slippers.)}

Beautiful, half-hardy annuals, from $1 \frac{1}{2}$ to 2 feet in height. Sow the seed early in frames, and transplant to a well enriched border.

Balsams. Improved Camelia=flowered. Finest mixed. Flowers very large and extra double. . . . . . . . . 5 c.

Balsams. Improved Camelia=flowered White Perfection. Pure white, with large; very finely formed double flowers. The plant with its stems thickly crowded with snowwhite blossoms, produces a magnificent effect....5c.

Balsams. Dwarf Spotted. Finest Mixed........5c.

Balsams. Double, Very Fine. Mixed. Rich, effective and popular......................

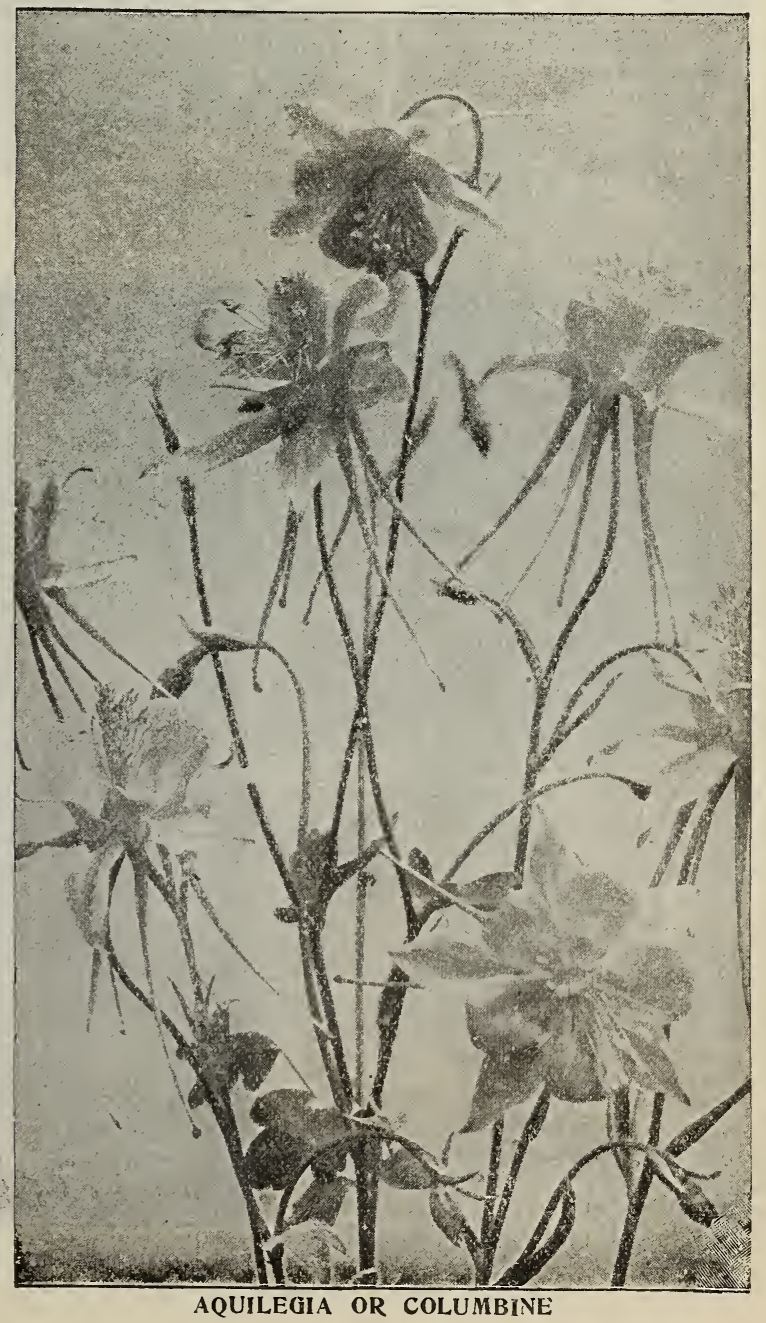




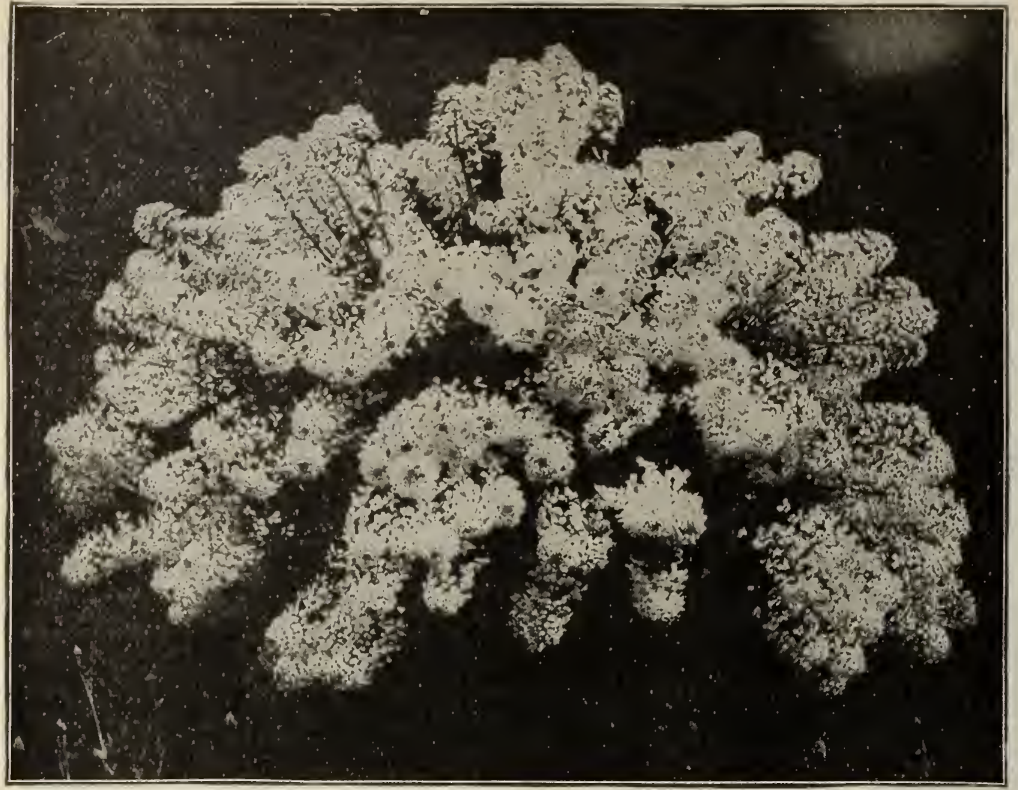

CANDYTUFT,

CENTAUREA.

Bachelor's Button or Centaurea Cyanis. A showy, hardy annual succeeding well in any soil, and bearing a profusion of flowers in shades of pink, blue and purple. Pkt., 5c.

Centaurea Margaret. Large, fragrant flowers; produced on long stiff stems. They are fine for cutting and decoration. Pkt., 5c.

Centaurea, New Giant Imperial. The best yet introduced. Grows 4 feet high, of enormous dimensions, covered with large, very fragrant flowers of an infinite variety of color. Pkt., 10c.

\section{CARNATION.}

Margaret Mixed. These carnations have created a universal sensation, not only on account of their beautiful colors, but, unlike all others, they bloom in about four months from sowing the seed. Bloom until checked by frost. Fully 80 per cent. are double, and embrace a fine range of brilliant colors. Plants are neat, dwarf branching and compact. Pkt. 10c.

Choice Double Mixed. Producing many double flowers of all shades and colors. Pkt. 10c.

\section{COLEUS.}

Gorgeous colored plants, with variegated foliage: indispensable for ornamental bedding, and fine for pot culture. Coleus, Fine varieties. Mixed. Pkt., 10c.

\section{CINERARIA.}

Beautiful free flowering plants for greenhouse and window garden. Flowers large, of rich colors, completely covering the plant with a mass of bloom. Finest mixed varicties. Pkt., 25c.

\section{CLARKIA.}

Single Mixed. Pretty hardy annual, about 18 inches high, blooming from June to September. Pkt., $5 c$.

\section{CANDYTUFT}

Showy, hardy annuals, very useful for edgings and masses, excellent for cutting; continuous bloom from July to October. Hardy an nual

Finest Mixed. 1 foot, $\mathrm{Oz} ., 25 \mathrm{c}$, Pkt., 5c.

Dunnetti Crimson. 1 foot, $\mathrm{Oz}$, 25c, Pkt, 5c.

Giant Empress. Very large white flowers, extensively used for forcing. 2 feet, Oz., 50c, Pkt., 5c.

Purple. 1 foot, Oz., 25c, Pkt., 5c.

Flesh Pink. 1 foot, $\mathrm{Oz}, 25 \mathrm{c}$ Pkt., 5c.

Dwarf White (Little Prince). 6 inch, Oz., 50c, Pkt.. 10c.

Gibraltarica. White shaded pink. Hardy perennial. 6 inch, $\frac{1}{4} \mathbf{O z}$. $\$ 1.00$, Pkt., 10c.

Sempervirens. Wh ite, glossy green foliage. Hardy perennial. 6 inch, Oz., 75c, Pkt., 10c.

\section{CANTERBURY BELLS.}

Very ornamental, growing about 2 feet high, producing beautiful, large, bell-shaped flowers, which make a glorious display when planted in large beds.

Canterbury Bells. Single, blue and white mixed.

Pkt., 5c.

Canterbury Bells. Double. Mixed. Pkt., 5c.

"CUP AND SAUCER" CANTERBURY BELLS.

(Campanula Calycanthema.)

A beautiful variety, vigorous and symmetrical in growth; often has thirty to forty large handsome flowers open at the same time on one stalk. Campanula Calycanthema. Splendid mixed. Pkt., 10c.

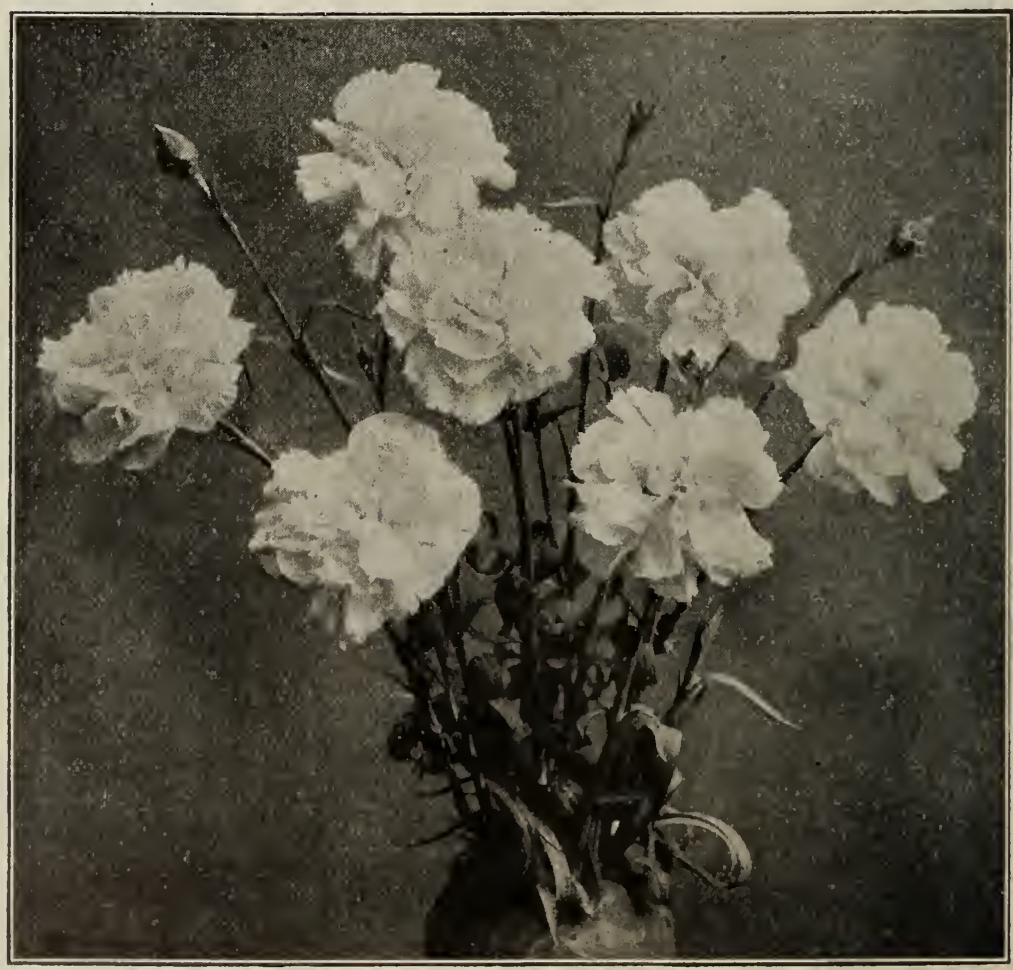




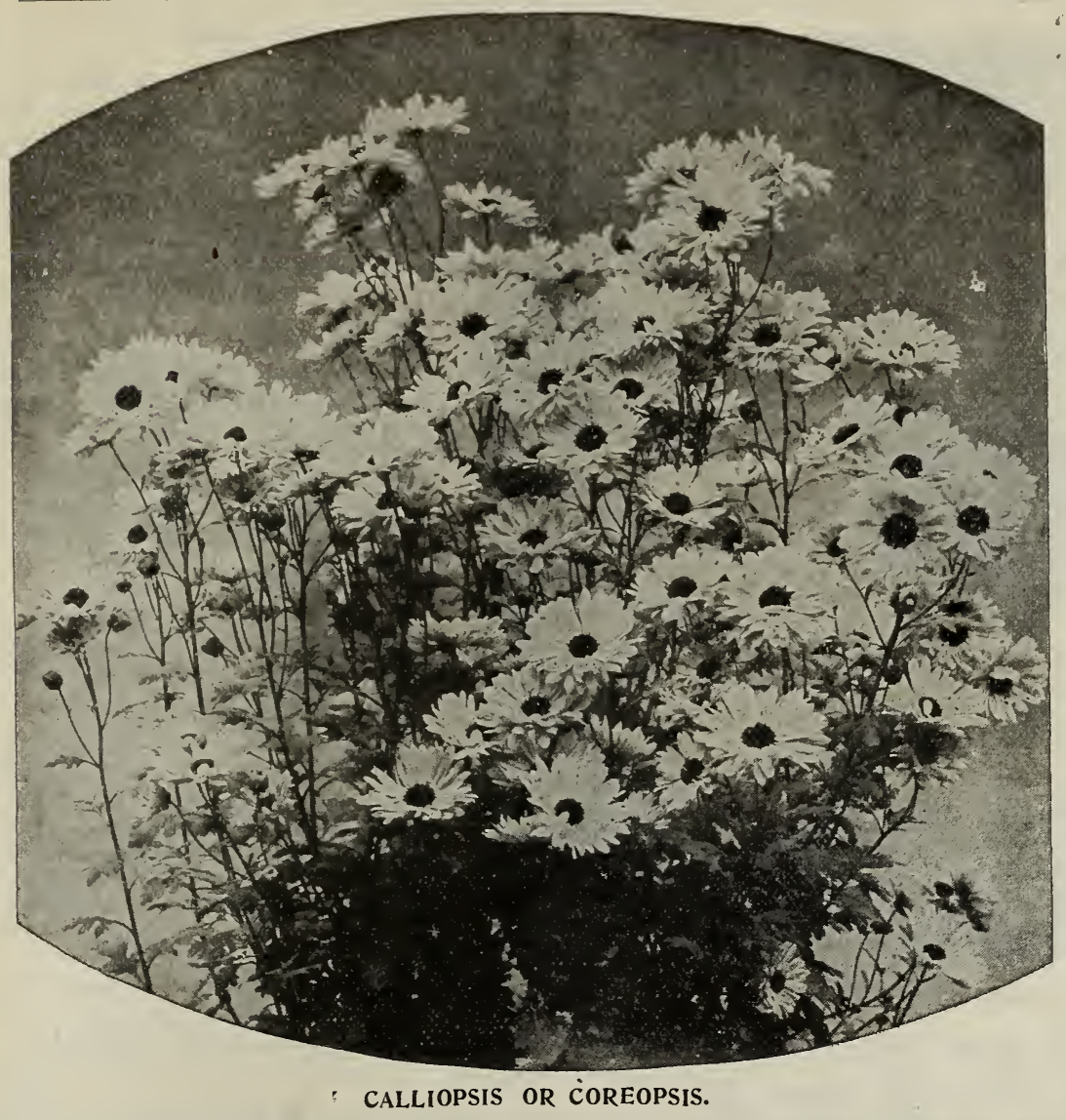

CALLIOPSIS OR CORE= OPSIS.

One of the most showy of all annuals, the colors being so striking as seldom to be passed without a remark.

Coreopsis. Drummond's. Yellow flowers, crimson center.............\$0.05

Coreopsis, Golden Wave. Very bushy and compact. A mass of bright, golden Color from July to Octaber. Flowers 2 inches across, with small dark centers..... . .05

Coreopsis. Mixed Varieties. Yellow and brown and velvety brown.......... .05

Coreopsis, Lanceolata. 'The perpetual Golden Coreopsis. Very free blooming and lasting in its golden glory throughout the summer and fall. Unequaled for cutting ................ .05

CHRYSANTHEMUMS.

Handsome hardy annuals producing quantities of large flowers of striking colors, making a brilliant display.

Single or "Painted Daisy"

Varieties Mixed....... .05 Single or Double Yellow. Flowers very double, globeshaped,extremely double. .05 Single or Double Fringed. Mixed. Flowers very double, with exquisitely fringed petals, in great diversity of colors, from white and yellow to blood-red purple...... . 10

COSMOS.

A very effective autumn flowering plant, with beautiful foliage, growing from 6 to $8 \mathrm{ft}$. high, literally covered with very large, single daisy-like flowers, in shades of rose, purple and white. For cutting, this is one of the finest flowers grown. Sow in April in pots or in the hot bed, and transplant one foot apart.

Cosmos. The Bride. Pure White. The White Cosmos is the most fragrant............... .10

Cosmos, Mammoth. New Fancy Varieties. In this splendid mixture are monster pink and white flowers, beautiful crimson shade, delicate white and mauve with daintily tinted and clouded with pink and mauve. Some large, white blossoms have broad plaited petals and pinked edges............. .10

Early Cosmos. Mixed. Extra early, blooming in July...... .05 CYPRESS VINE.

Most beautiful and popular tender climber, with very delicate, fernlike foliage and numerous flowers.

Cypress Vine. Scarlet. Very Brilliant.............. .05 Cypress Vine, White....... .05

Japan Crimson. Huge combs, much cut and beruffled...................... $\$ 0.10$

Glasgow Prize. Dark leaves and crimson combs; $1 \mathrm{ft} \ldots \ldots \ldots \ldots \ldots \ldots \ldots \ldots \ldots$

Dwarf Yellow .................. ، $\quad .10$

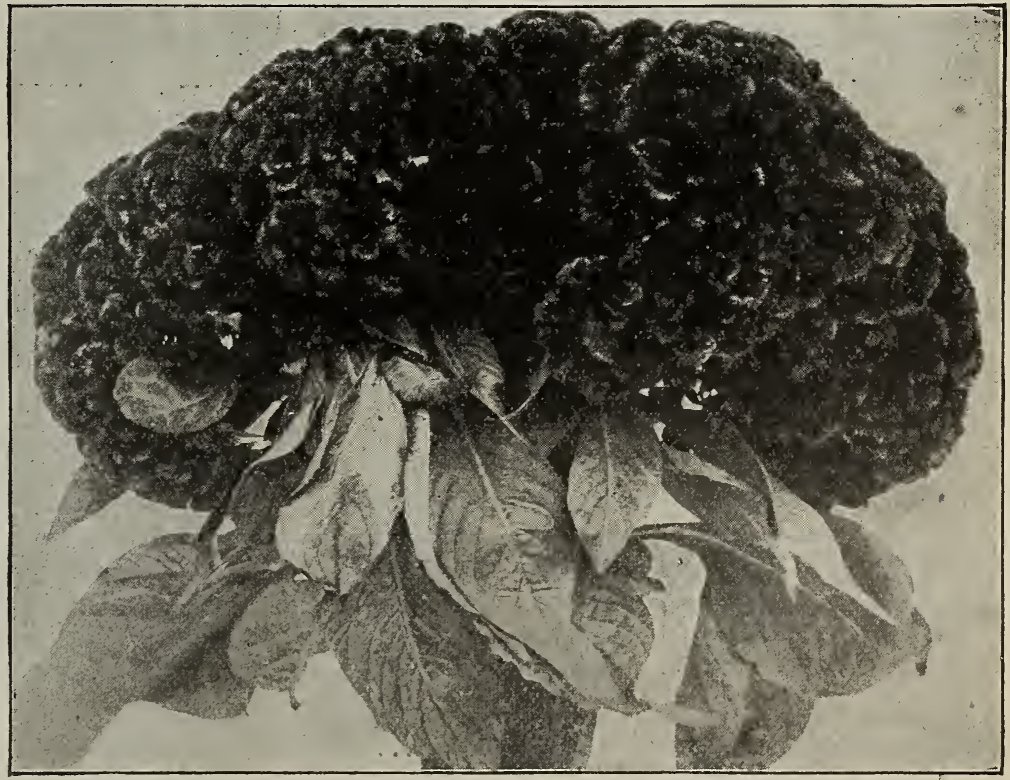

COCKSCOMB.

соскSсомв.

Dwarf Fiery Scarlet. A miniature plant, with enormous combs of intense fiery red.... pkt., $\$ 0.10$

Dwarf White....................... .lú

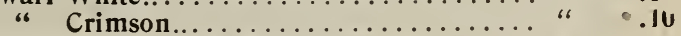
Mixed. Extra large combs ......... a $\quad .10$ 


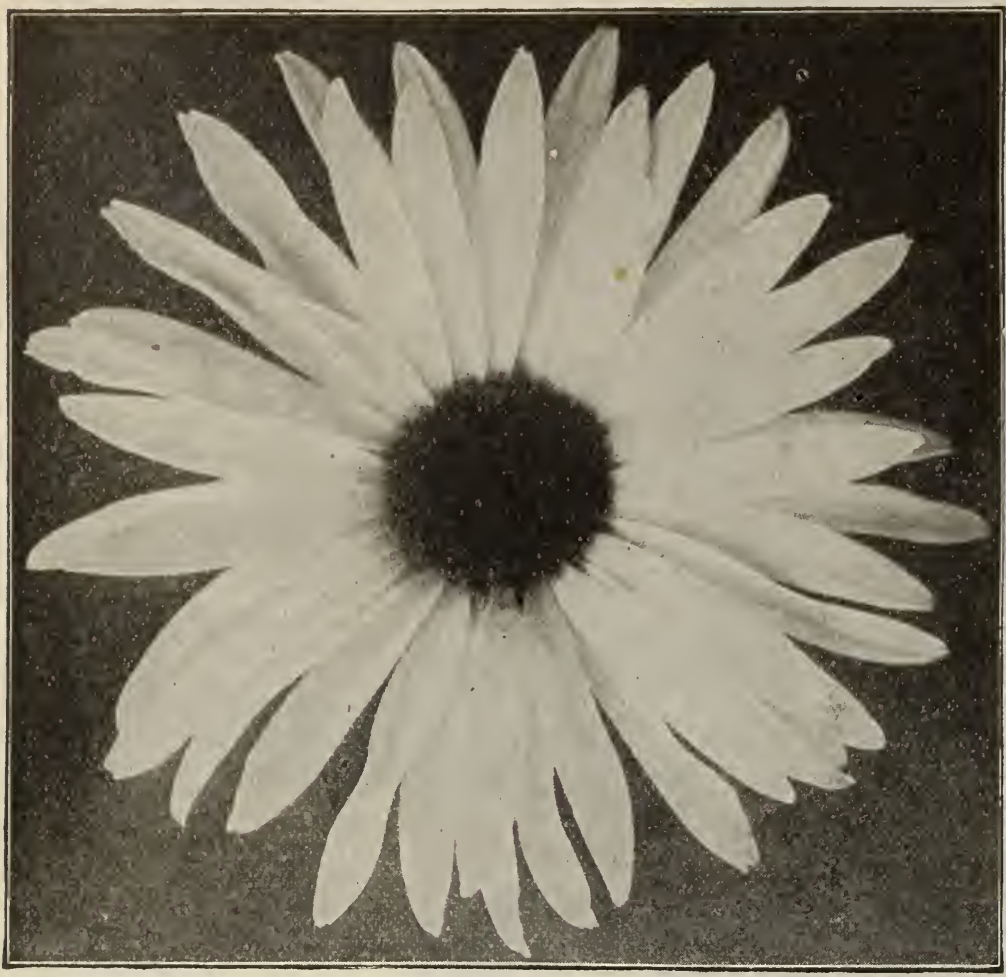

SHASTA DAISY.
SHASTA DAISY.

This is one of the creations of Mr. Luther Burbank. It is perfectly hardy, grows anywhere and blooms more abundantly each season. The flowers are very large, a foot or more in circumference, growing on long stems, with two rows of broad, pure white petals and a yellow center. Pkt., 10c.

DOUble DAISY. (Bellis Perennis.)

Charming plants for edging and dwarf beds, blooming the first year from seed. Thrive well in shady places.

Daisy, Snowball. Large flowered, pure white, and extremely double, with very long stems, making them valuable for cutting.. .10 Daisy, "Longfellow." Flowers of unusual size, a dark rose color................. $\quad 10$

Daisy, Double. Mixed..... . .05

\section{DAHLIA.}

Sow the seeds early in pots or under glass, and transplant to strong, deep, rich soil, and plants will bloom the first season.

Dahlia. Single Varieties. Splendid mixture. Handsome bedding plants, and extensivly used for cutting.......... 10

Dahlia Single. Perfection or Giant. A splendid strain. The seed being gathered from the broadest petalled flowers only, reproduces them in a variety of the most splendid colors, among

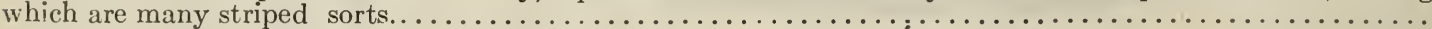

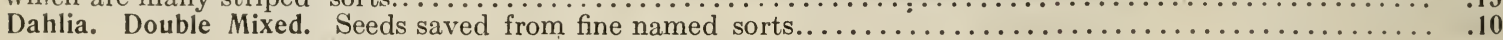

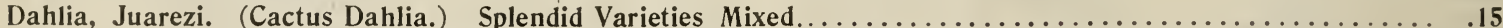
Dahlia, Double Gloria. Perfectly new race in a great diversity of forms. One plant produces its flowers as a double Scabiosa, another as a double Gaillarida, a third as a peony-flowered Aster, the next as a perennial Pyrethrum, another as a double Zinnia, and still another as a rosy red Giant Daisy. Their colors are

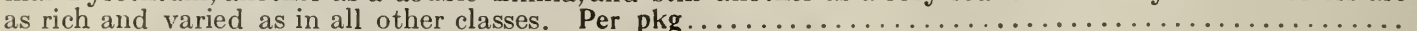

\section{DATURA. (Trumpet Flower.)}

Showy plants, producing very large, sweet scented, trumpet-shaped flowers. Roots should be removed to cellar in autumn.

Datura. Wright's. White, bordered with lilac. Per pkg .............05

Datura, Golden Queen. Beautiful, double, yellow flowers, fragrant. If seed is sown indoors in March, plants will bloom in July. From that time on they will be covered with their large and showy flowers. Per Pkg..............

\section{DELPHINIUM. (Perennial Larkspur.)}

Flowers remarkable for their great beauty, diversity of shades, and striking appearance. Desirable for mixed borders. If sown early will bloom first year from seed.

Delphinium Formosum. Our flowers were two inches in diameter by actual measurement, brilliant azure blue in color. Spikes 8 to 10 inches in length

Delphinium Elatum. (Bee Larkspur.) Blue. $2 \mathrm{ft}$. Delphinium Hybridum. Fine Mixed, Splendid...

OUR WILD FLOWER GARDEN MIXTURE Comprises many varieties of beautiful, hardy, easy growing flowers that will produce a constant and varied bloom all summer. This mixture comprises Mignonette, Candytuft, Larkspurs, Poppies, Pinks, Asters, Foxgloves and many others that are equally as great favorites. Large pkt., 5c.; oz., 10c.

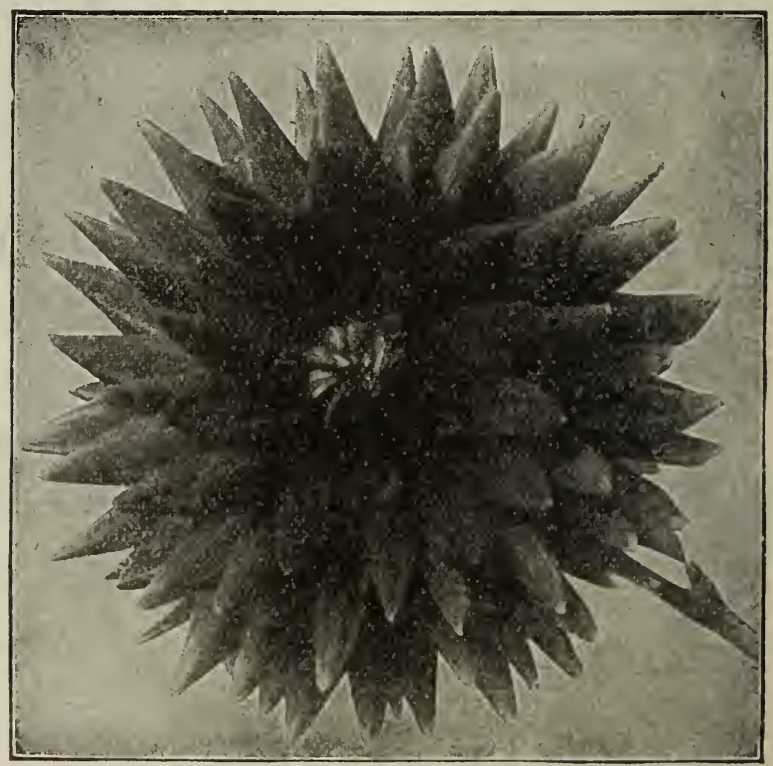

CACTUS DAHLIA. 


\section{EUPHORBIA.}

Euphorbia Heterophylla. "Mexican Fire Plant." Large, bushy plants growing about 3 feet high. Sow early in pots or hot bed, and

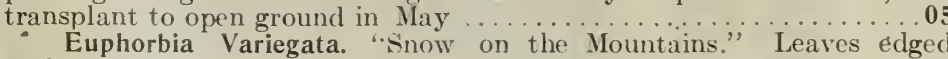

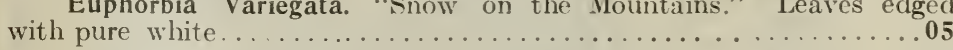

\section{ESCHSCHOLTZ1A-(California Poppy.)}

A very showy plant, about 1 foot high, blooming from June until September. Produces a brilliant effect at a distance when grown in a mass. Hardy.

Eschscholtzia, New Giant, "The Golden West." Flowers very large with overlapping petals, often delicatoly waved at the edges In some the orange blotch almost suffuses the whole flower, in others it runs into the yellow in fine penciled lines; others again have an orange center with a margin of clear yellow, while the Maltese cross in some of the flowers is very distinct.

Eschscholtzia. Finest Mixed . . . . . . . . . . . . . . .

Eschscholtzia. Double Mandarian. Large double flowers........ 05

\section{FORGET $=$ ME $=$ NOT $-($ Myosoiis. $)$}

A very pretty, little, hardy perennial, about 6 inches high. Will thrive best in a cool, moist situation, and is well adapted for bedding or

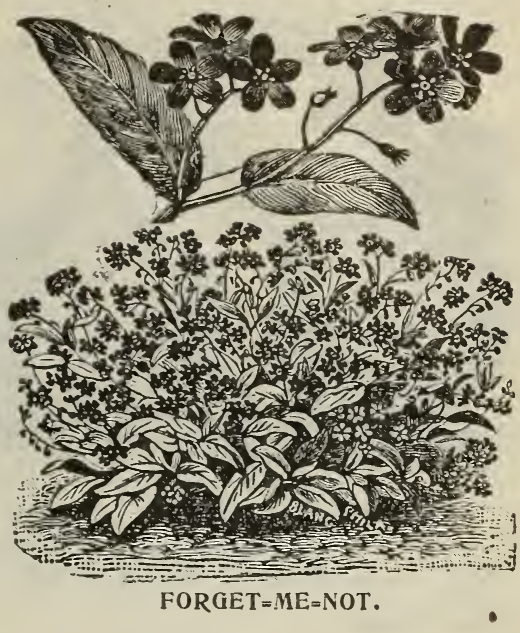
rockwork

Forget=Me=Not. Distinction. Very dwarf and free-flowering, blooming two months after seed is sown ....10

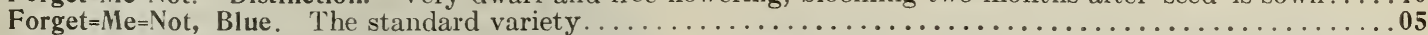

Forget=Me=Not, "Jewel." This variety produced on a long flower stem a perfectly formed, brilliant skyblue head

\section{FEVERFEW-(Matricaria.)}

A beautiful half hardy perennial, well adapted for beds. Feverfew, Double Dwarf. Flowers large, creamy-

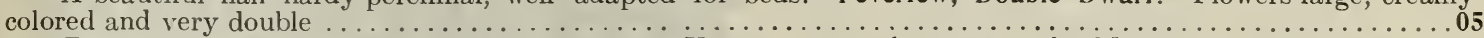

Foxglove, Large Flowering. Spotted and Mixed. Very ornamental amongst shrubbery, producing tall spikes of showy flowers of purple, rose, white and yellow ..............

Elegant flowering plants, of easy culture in pots for parlor decoration or in the garden. In the garden they require a slightly shaded situation. Soil should be rich. Fuchsia. Finest Varieties. Mixed .............

GAILLARDIA

One of the most showy and brilliant of garden flowers, fine for bedding and cutting, producing large flowers of

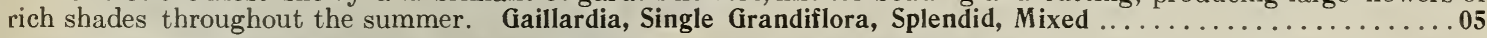

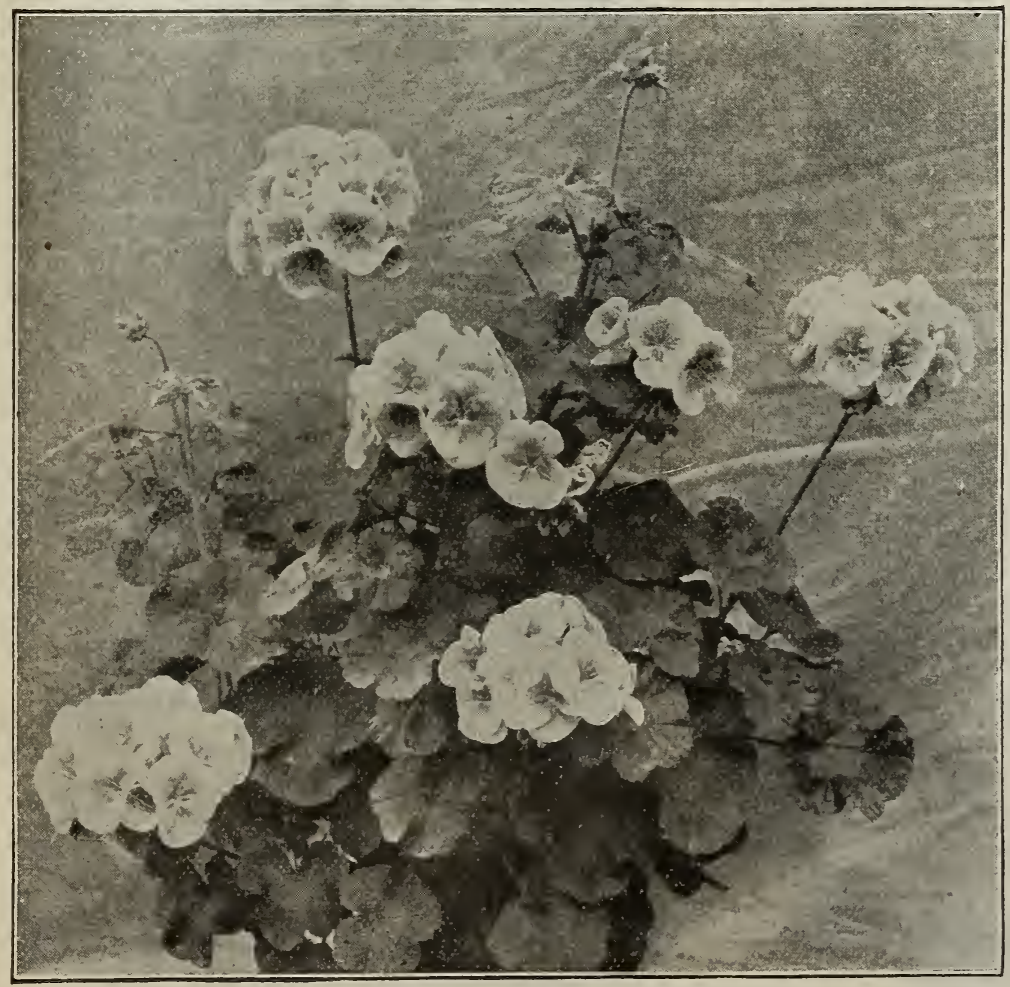

GERANIUM ZONALE.
Gillardia. P i c t a Lorenziana, Double. Flowers very double, of various shades, orange, claret, anaranth, sulphur, etc.........05

\section{GERANIUM}

Giant Flowering Hybrids. A strain of seed saved from fine new improved Hybrids. The colors are all shades of scarlet, crimson, rose, pink, salmon, cream, veined pink, blush, pure snowy white.......15

Geranium. Z o n a le Varieties. Saved from some of the finest collections; many choice and entirely new varieties may be expected................Pkt., 10

\section{IPOMEA}

Very beautiful and popular climbers; deservedly so from the fine foliage and the brilliant and varied hues of its many flowers. Fine for covering old walls, stumps of trees, etc.

Ipomea B o n a Nox. (Evening Glory.) Allied to the Morning Glory, but differs from it, choosing the evening for its time of blooming ................ 10

Ipomea, Mexicana Grandiflora Alba. Large white flowers with a delicious fragrance......... 10 Ipomea, Large=flowering. Mixed.05 Quamoclit. (Cypress Vine).....05 


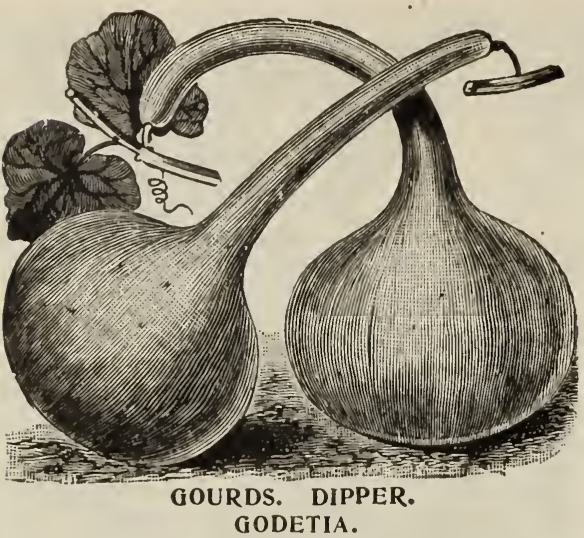

Very attractive, hardy annuals, about one foot high. Flowers of a beautiful satiny texture.

FInest Mixed.

.05

GLOBE AMARANTH.

Tender Annuals about $2 \mathrm{ft}$. high, very ornamental in the garden. The flowers will retain their beauty for a long time if gathered and dried as soon as they are open.

Globe Amaranth. Variegated and Mixed.

\section{HELIPTERUM.}

Helipterum Sanfordi. A variety of everlasting flowers, of great beauty; of dwarf tufted habit; producing large, globular clusters of bright golden-yellow flowers.

\section{HIBISCUS.}

New perennial Hibiscus. Crimson Eye. A robust grower with dark red stems and foliage. Flowers immense, often measuring 20 in. in circumference, pure white, with a large spot of deep velvety crimson in the center of each flower..

\section{GYPSOPHILA PANICULATA.}

Remarkably hardy plants $1 \frac{1}{2} \mathrm{ft}$. high, growing well in any soil and flowering profusely in graceful sprays of fine white. Much esteemed for bouquets

\section{GOURDS.}

Hen's Egg. For nest eggs; handy when darning stockings . $\quad .05$ Hercules' Club. Grows 4 to $6 \mathrm{ft}$. in length...............05 Sugar Trough. For holding liquids. They will last years.. . .05 Double Bottle .............................. .05

Dipper. Used as its name indicates.............. .05

Useful, Fancy and Ornamental. Mixed varieties ...........05

Towel Gourd, or Luffa. Many ladies prefer a dish cloth made of this Gourd to anything else, as it is always sweet and clean as long as any part of it is left.

\section{HELICHRYSUM.}

Ornamental in the garden and desirable for winter bouquets, as they retain their form and color for years, if gathered and dried when first open.

Helichrysum. "Fireballs." Rich crimson-maroon................ .05

Helichrysum, Yellow............ .05

Helichrysum, Mixed................ .05

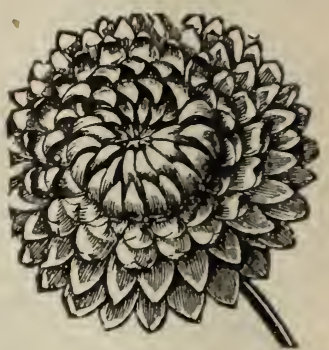

HELICHRYSUM.

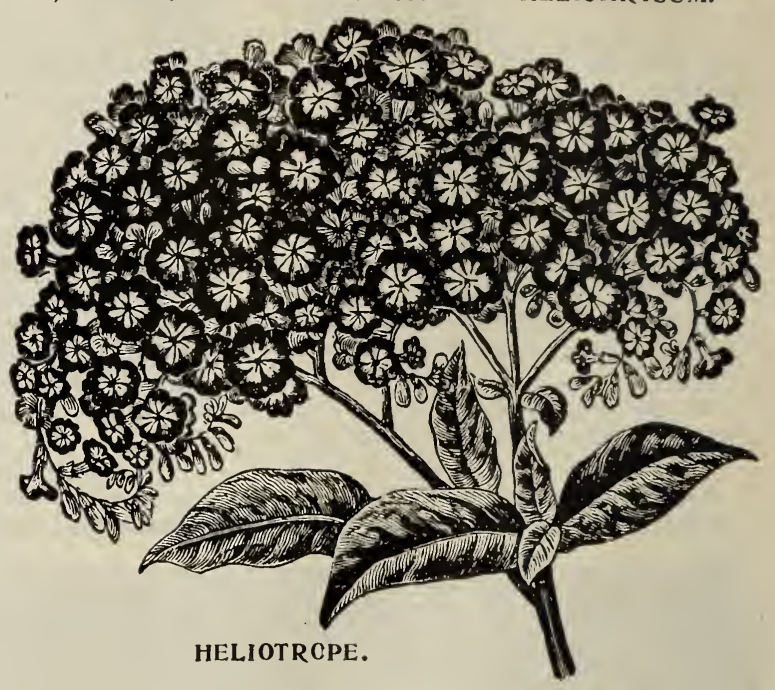

HELIOTROPE.

Well-known, deliciously fragrant plants, excellent for bedding purposes or pot culture Heliotrope Mixed

Heliotrope, New Mammoth. Very sturdy and branching, producing immense umbels of light and deep violet flowers. The delicious perfume of this novelty far exceeds the well-known Giant sort.....

\section{HOLLYHOCKS.}

Seeds should be sown in June or July to have flowering plants the next summer; or, if sown in the house early in the spring they will bloom the first year.

Hollyhocks, Chater's improved D'ble. Mixed .10 Hollyhocks Snow White.. .15 Rose... .15 Hollyhocks, Sulphur Yellow .15 .Purple.. .15 Seed saved from one of the finest collections, and will produce very large double flowers of striking beauty.

Hollyhocks, Tall, Double. Mixed.

ICE PLANT.

A singular looking, tender annual, with thick fleshy leaves that have the appearance of being covered with crystals of ice...

IMPATIENS SULTANI. (Sultan's Balsams.) A perennial balsam of compact growth, producing almost continuous charming bright, rose-colored flowers . .........

5

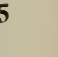

5

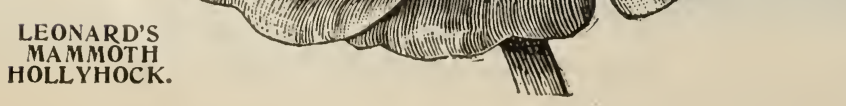




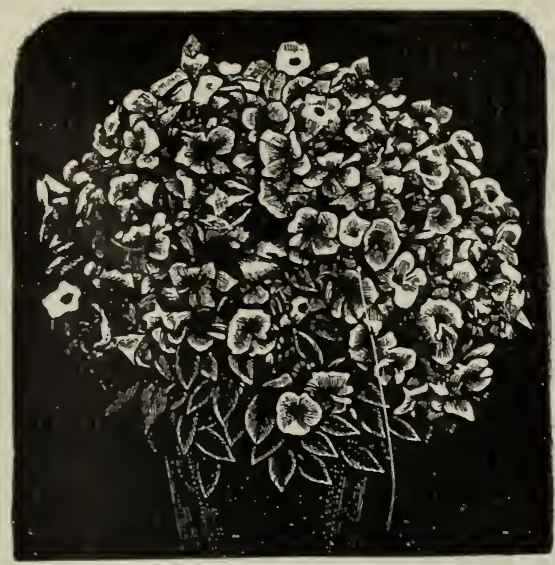

LINUM.

Kochia Scoparia, or Summer Cypress. Burning Bush. The plants are always of globe-like form, branching freely, the stems being covered with delicate light green foliage. Early
in the fall the ends of the shoots are thickly set with small bright scarlet flowers, the bushy plants resembling balls of fire. Very showy when planted singly to show the round ball-like form. Pkt., $5 \mathrm{c}$.

\section{LANTANA.}

This showy greenhouse plant forms a small bush, covering itself with pink, yellow and orange flowers, and also flowers of changeable color. Start in the house. Fine varieties mixed. Pkt., 10c.

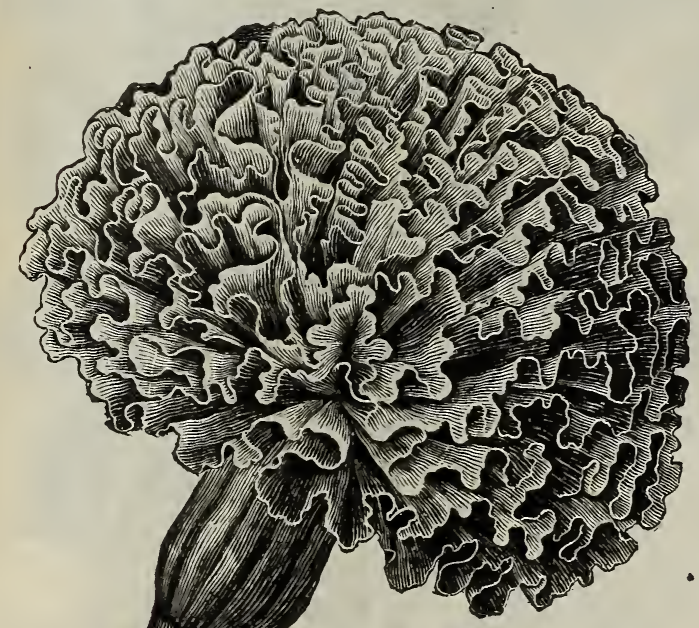

LOVE $=\mathrm{IN}=\mathrm{A}=$ MIST. (Nigella.)

A curious plant about 1 foot high, with finely cut leaves and single flowers.

\section{LUPINS.}

Lupins. Mixed. Showy hardy plants from 2 to 3 feet high, producing spikes of attractive flow
MARVEL OF PERU. (Mirabilis.)

ELDORADO.

The old and well-known Four O'Clock. Fine plants, flowers various colors, making a fine summer hedge, set 1 foot apart. ...

\section{MARIGOLD. (Targetes.)}

Extremely showy, 1 to 2 feet high, well adapted to garden culture, blooming profusely through the season.

Marigold, French. ("Charter's Butterfly.") A beautiful variety with alternate petals of velvety purple-brown and old gold

Marigold olvet purploming from july until frost. Flowers -single, of a beautiful, rich, golden-yellow with large until frost. Flowers sing

Marigold, African. (E1 Dorado.) (See Cut.) Flowers 3 inches in diameter, in all shades of yellow lemon, primrose, gold and deep orange.................... Marigold, Calendula, Prince of Orange. Flowers striped with an intense, glowing shade of orange.

Marigold, Meteor, Large =flowered. Flowers dark orange red, double, very large

Marigold, African. The old-fashioned sort, greatly improved in size $\ldots \ldots \ldots \ldots \ldots$
Marigold, French..$\ldots \ldots \ldots \ldots \ldots \ldots \ldots \ldots \ldots \ldots \ldots \ldots \ldots \ldots \ldots \ldots$
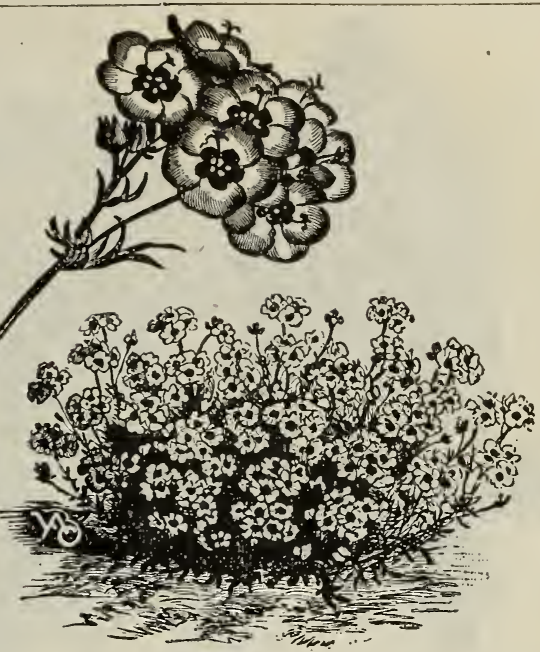

LOBELIA.

LOBELIA.

Strikingly pretty, profuse blossoming plants; the delicate, rooping habit of the Erinus varieties renders them fine for of blooms, are splendid for beds, ed gings, etc

Erinus. Mixed. Blue, white, and blue and

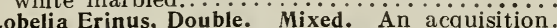
.05 10

obelia Compacta. Crystal Palace. Dark Blue........ nial a Cardinalis. (Cardinal Flower.) Hardy perenbelia Cardinalis Grandiflora. Flowers of brilliant scar.10 .25

\section{LARKSPUR.}

Veautiful; hardy annuals, producing dense spikes of flowers, are very decorative, either in the garden or when cut for arkspur Stock=flowered. Tall-branching, finest mixed.

Emperor, Double. Finest Mixed. Very beautiful

Hyacinth-flowered. An improved type........ 05

(1) Rocket, Double, Mixed. Plants large and showy .05

inaria, Royal Purple. The nearest approach in general effect

LINUM. (Flowering Flax.)

Linum Grandiflorum Coccineum. . One of the handsomest annuLYCHNIS.
There are few plants that produce more brilliant-colored blos-
Th than Lychnis. The flowers are produced in clusters, and are constantly coming out all summer. Hardy perennials; one to three feet high.

Chalcedonica. (London Pride.) Bright scarlet; two feet high.

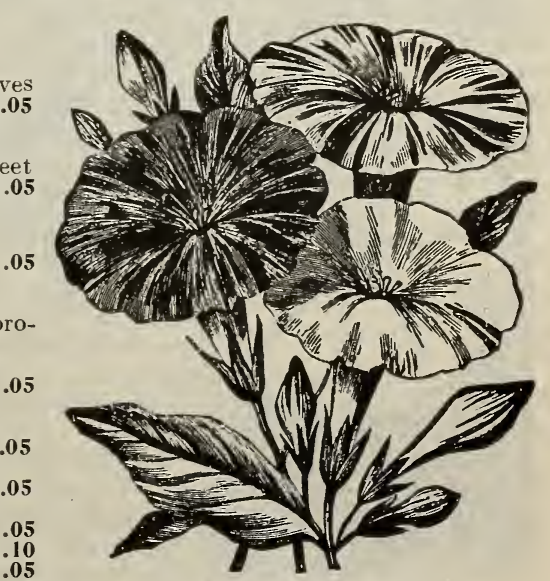

MARVEL OF PERU. 


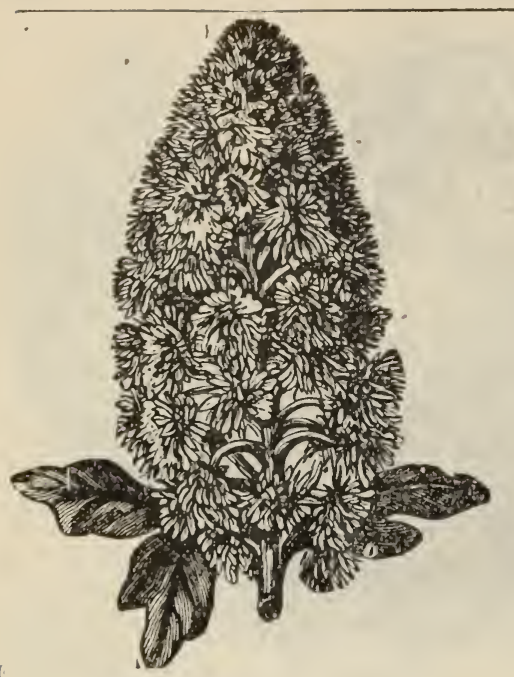

MIGNONETTE MACHET.

\section{MIGNONETTE.}

A general favorite on account of its delightful fragrance. Blooms throughout the season. Sow from middle of April to middle of June. Most fragrant on poor soil.

Mignonette, Myles' Hybrid Spiral. Plant dwarf and branching; flowers white, very fragrant, spikes 8 to 14 inches long. Fine for outdoor or pot

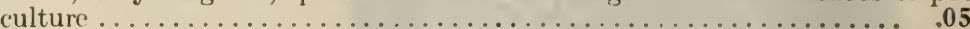

Mignonette, Orange Queen. An ideal Mignonette. The growth is dwarf and compact, leaves thick and of a fine green. The enormous spikes are closely filled with large flowers of a beautiful orange color; very frag-

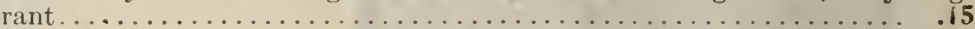

Mignonette, Machet. Plants divarf and vigorous, of pyramidal growth with broad spikes of very fragrant red flowers. Fine for pot culture and equally valuable for borders. Per $0 z ., 75 \mathrm{c} \ldots \ldots \ldots \ldots \ldots \ldots \ldots . .10$

Mignonette, Allen's Defiance. Spikes of remarkable size, and deliciously fragrant, much more so than any other variety, and they retain their grace and fragrance until every bud opens

Sweet...

Per oz.

i5 $\quad .05$

\section{MAURANDIA.}

A delicate free-flowering climber, for the conservatory or trellis work in the garden; also desirable for hanging baskets. Start early in pots, transplant when the weather becomes warm.

Maurandia Barclayana. Rich violet................05

Maurandia, Mixed. Violet, white, rose and pink...................

MIMULUS. (Monkey Flower.)

A half-hardy plant, of the easiest culture, about 9 in. high, producing a profusion of very pretty flowers. It is perennial in the greenhouse, and may be easily propagated by cuttings. Select a moist, rather shaded location.

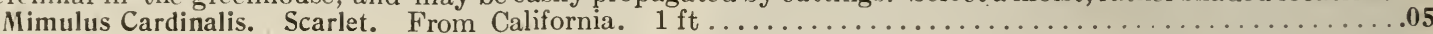

Mimulus Moschatus. (Musk Plant.) Much esteemed for its strong musk odor .05

MOURNING BRIDE. (Scabiosa.)

A class of beautiful hardy annuals, from 1 to $2 \mathrm{ft}$. high; valuable for cutting, as they remain a long time in bloom and do not droop easily.

Mourning Bride. Snow Ball. Pure White.

Very large and extremely double ...... $\quad .10$

Mourning Bride. Mixed.

Mourning Bride. Fiery Scarlet. A new, beautiful, very large flowering variety of brilliant color.

MORNING GLORY. (Convolvulus.)

Climbing plants; unequaled for rapidity of growth and profusion of bloom, annuals attaining a height of 30 to $50 \mathrm{ft}$.

White. Oz., 10c.; pkt., 5c.

Red. Oz., 10c.; pkt., 5c.

Blue. Oz., 10c.; pkt., 5c.

Mixed. Oz., 5c.

Dwarf Morning Glory. All colors mixed. Oz., 10c.; pkt., 5c.

GIANT IMPERIAL JAPANESE MORNING GLORIES.

The flowers of these morning glories are double the size of the ordinary morning glory, running from 4 to 6 in. across. The vines are strong and robust, growing from 30 to $50 \mathrm{ft}$. high during the season. The leaves are heartshaped. Some vines have dark green foliage, others have silvery leaves, or yellow. Some

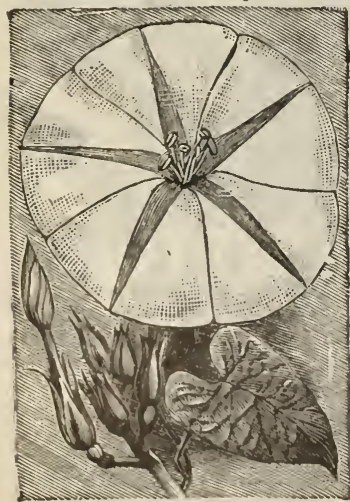

lark green, white
dark and gray. The chief beauty, however, is not their leaves or gigantic size, but the beautiful coloring of the large flowers. 'The colors, shading, and markings are numberless. All colors mixed. Oz., 10c., pkt., 5c.

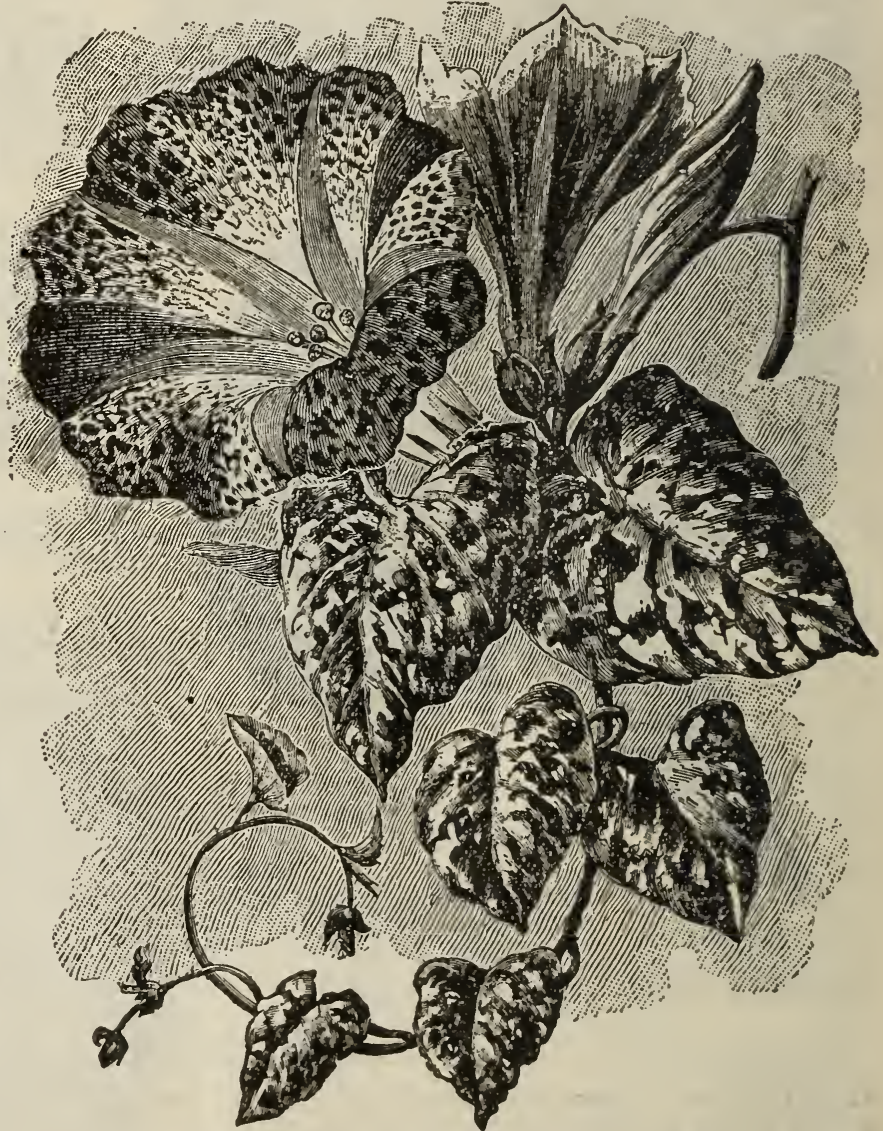

GIANT IMPERIAL JAPANESE MORNING GLORIES. MOON FLOWER. (Ipomœa Grandiflora Alba.)
This is one of the most vigorous of all the summer climbers Will grow 30 to $40 \mathrm{ft}$. in a single season, and will be covered with its large, white flowers every evening and cloudy day. The hard, outer coat of the seed should be cut through with a sharp knife, care being taken not to cut any deeper than the hard shell, and the seed planted about

MOON FLOWER. 


\section{NASTURTIUM}

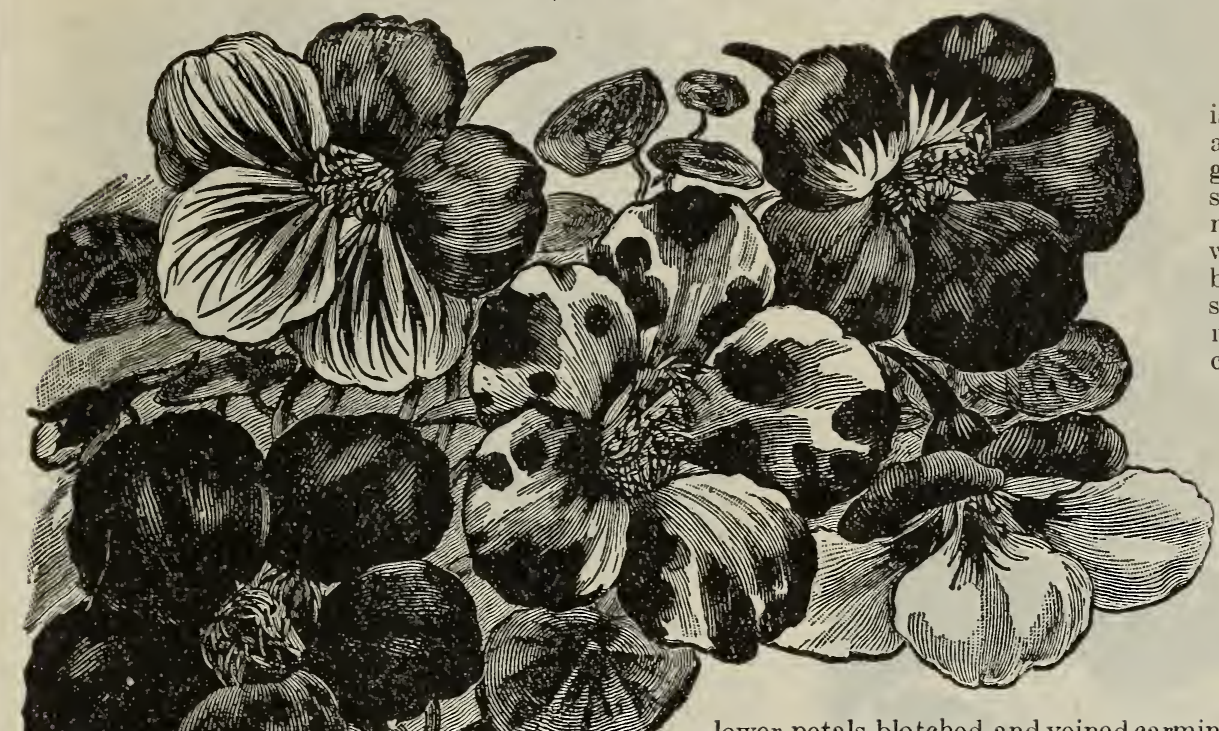

LEONARD'S OAK PARK BEDDING.

The illustration is a photograph of a spray of flowers groyn from this exquisite blend of bedding nasturtiums. It is well adapted for ribbon beds or borders, and is strikingly effective in masses. This blend contains seed saved from the largest flowering, most beautiful and varied collection ever sent out. Pkt., 5c.; oz., 10c.; 11 lb., 25c.; $\frac{1}{2}$ lb., 40c.; lb., 75c.; postpaid.

DWARF OR TOM THUMB.

Aurora. Crome yellow, the two Pkt. 5c.; 0z., 10c. Beauty. Golden orange, flamed scarlet. Pkt., 5c.; oz., 10c. Bronze Color. Of a burnished coppery bronze. Pkt., 5c.; oz., 10c. Chameleon. Not only are the flowers of various colors produced on the same plant, but these flowers are variously blotched, striped and bordered in rich contrasting shades. Pkt., 5c.; oz., 10c.

Cloth of Gold. Golden yellow foliage, flowers scarlet. Pkt., 5c.; oz., 10c.

Crystal Palace Gem. Sulphur yellow, spotted maroon. Pkt., 5c.; oz., 10c.

Golden King. Grand flowers three inches across; deep golden yellow, maroon blotches. Pkt., 5c.; oz., 10c.

Empress of India. Brilliant crimson, dark foliage. Pkt., 5c.; oz., 10c.

Princess Victoria Louise. Cream white, spotted with deep scarlet; fi n e 1 y veined

Golden Yellow flowers on Golden Foliage. Pkt., 5c. King of Tom Thumbs. Crimson. Pkt., 5c.; oz. 10c. King Theodore. Deep chocolate crimson, dark foliage. Pkt., 5c.; oz. 10c. Lady Bird. Ground color is a rich golden yellow, each petal barred with ruby crimson Pkt.,

NASTURTIUM=0AK PARK COLLECTION. 5c.; oz., 10c.
Lillie Schmidt. Orange yellow, blotched with brown. Pkt., 5c.; oz., 10c.

Pearl. White. Pkt., 5c.; oz., 10c.

Prince Henry. Cream color, spotted scarlet and tipped with wine red. Pkt., 5c.; oz., 10c.

Regalianium. Violet ruby. Pkt., 5c.; oz., 10c.

Rose. Pkt., 5c.; oz., 10c.

Ruby King. Light ruby red. Pkt., 5c.; oz., 10c.

Spotted. Deep orange crimson blotches. Pkt., 5c.; oz., 10c.

\section{TALL OR CLIMBING NASTURTIUMS.}

Dark Crimson. Rich and velvety. Pkt., 5c.; oz., 10c.

Edward Otto. Flowers brownish lilac with a yellow spur. Pkt., 5c.; oz., 10c.

Heinemanni. Silky bronze chocolate Pkt., 5c.; oz., 10c.

Hemisphæricum. Very showy, lemon yellow with crimson blotches. Pkt., 5c.; oz. 10c.

King Theodore. Velvety dark brown. Pkt., 5c.; oz., 10c.

Nankeen. Yellow. Pkt., 5c.; oz. 10c.

Leonard's Special Mixture of Tall Nasturtiums, per pkt., 5c.; oz., oz., $15 \mathrm{c}$.

$10 \mathrm{c}$., $\mathrm{l}=4 \mathrm{lb}$., $25 \mathrm{c}$.; 1b., $75 \mathrm{c}$.

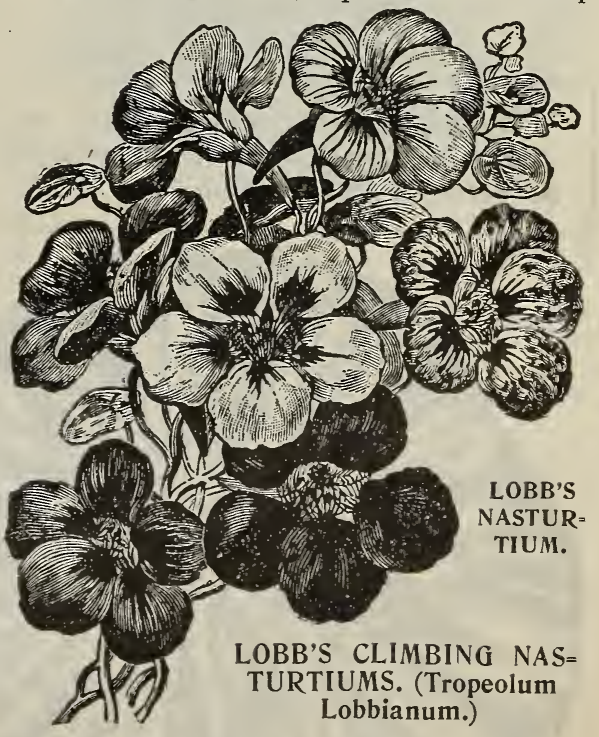

They are as easily grown as the common Tall Nasturtium, which they far surpass.

Brilliant. Deep scarlet. Pkt., 5c.; oz., 15c. Crystal Palace. Very bright, orange, salmon

flowers. Pkt., 5c.; 0z., 15c.

Spitfire. Bright, fiery scarlet. Pkt., 5c.;

Choice, mixed. Pkt., 5c.; oz., 15c. 


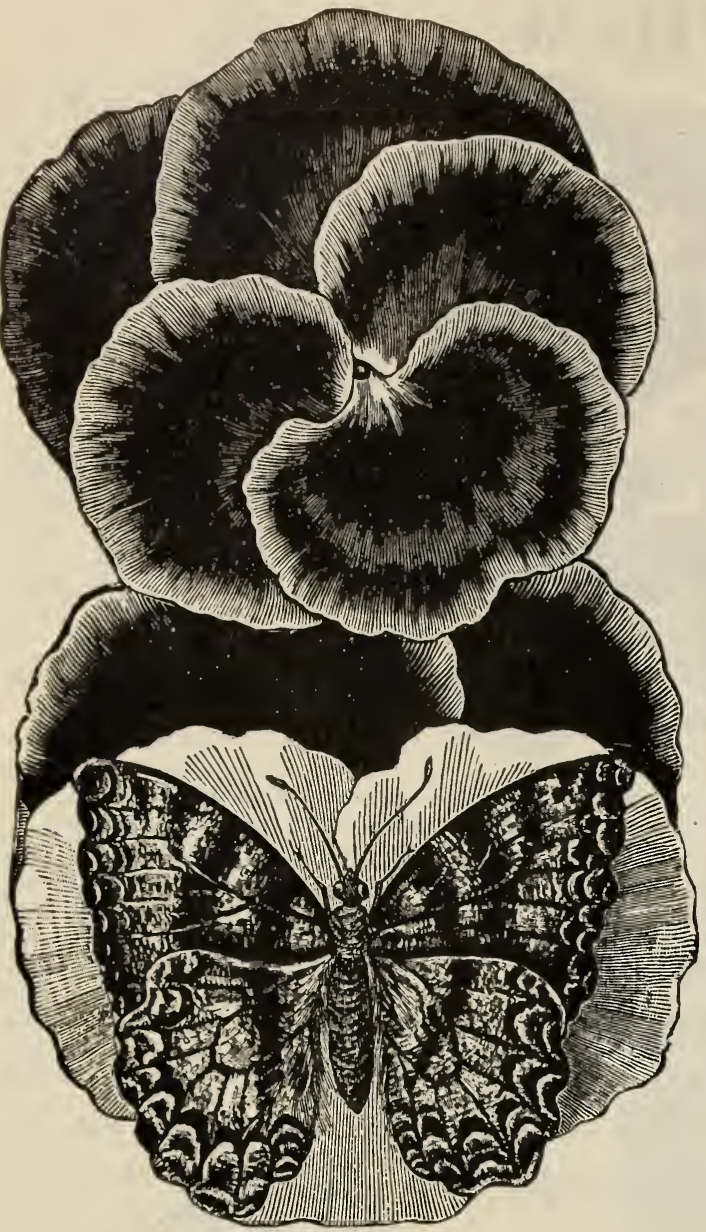

LEONARD'S GIANT BUTTERFLY.

We use every effort to secure the best strains of Pansy, and feel confident that no better seed is obtainable.

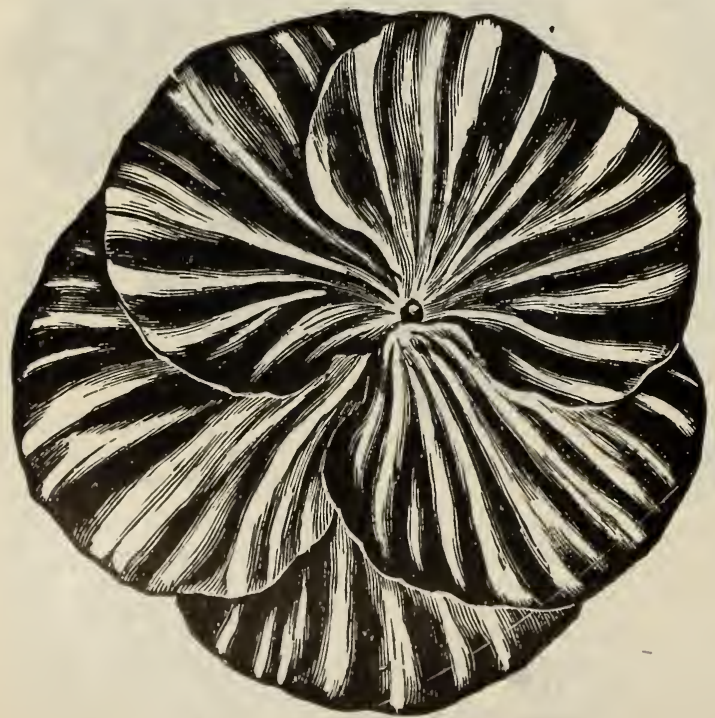

OIANT FANCY STRIPED PANSY

\section{NICOTIANA}

A handsome genus of garden plants of the tobaceo family, which are noted for the freedom and fragrance of their bloom. Half hardy ainnuals, $3 \mathrm{ft}$. high. Flowers white, salver shaped, having long, tubular corollas, and are of exquisite fragrance. Deserves a place in every garden.

Affinis .

Sanderac

NOLANA

Very pretty, trailing, hardy annuals, fine for rockwork. hanging baskets, or for bedling. Mixed Colors. . 05

\section{OXALIS}

A splendid class of plants suitable for hanging pots or rustic baskets. Particularly adapted for the parlor, where they bloom in midwinter. Half-hardy.

Oxalis Rosea. Rose colored flowers, bloom abundantly ............................ .05 Oxalis Tropaloides. Deep Yellow flowers; brown leaves........................... .05

\section{PANSIES}

Leonard's Special Strain of Giant Five=Spotted Pansy. Enormous size Pansies of rich, velvety texture. Every one is different and all are distinctly marked with rich and varied shades and colorings. These pansies are the most perfectly formed of any we have ever seen. Flowers are carried on good strong stems and are of good substance. Their robust growth makes them a general favorite. Every lover of pansies should try this strain. Pkt., 15c.

Leonard's Giant Prize Mixed Pansies. Largest prize varieties. Grand, rich, velvety colors. Pkt., 10c.

Leonard's Giant Butterfly. This strain is beautifully marked and blotched. Large, fine form and of endless colors. Pkt., 10c.

Giant Red. Bright coppery shades. Pkt., 10c.

Giant Mahogany. A velvety, reddish brown. Pkt., 10c.

Giant Uncle Tom. Finest black, deep jet; very velvety and large. Pkt., 10c.

Giant Lord Beaconsfield. Flowers deep purple violet, shading to white at the upper petals. Pkt., 10c.

Trimardeau Giant. The largest of all the pansies. The blossoms are simply enormous, perfect in form and run through all the varieties of colors, from the lightest shade to the darkest purple. Marked with three large blotches. Pkt., 10c.

Giant Odier. Handsome blossoms; being very large and perfect in form with dark, deep velvety blotches, margined with an endless variety of colors; extra large and fine. Pkt., 10c.

Victoria. The best red pansy. It is a beautiful, rich deep red color throughout. Large, velvety and of fine form. Pkt., 10c.

Giant Brown. All shades of this color. Pkt., 10c.

Giant Blue. All shades of light and dark blue.

Pkt., 10c.

Giant Yellow. From the lightest yellow to the deepest old gold. Pkt., 10c.

Giant Purple. Rich velvety Pkt., 10c.

Giant Snow Queen. (Candidissima.) Very large, satiny, pure white. Fine for bouquets or cemetery use. Pkt., $10 \mathrm{c}$.

Giant Emperor William. Large, handsome flowers, borne in great profusion well above foliage. Brilliant ultramarine blue, with a purple violet eye. Pkt., 10c.

Fine Mixed. A very good strain in a great variety of colors. Pkt., 5c.

Bugnot's Large Stained Parisian. Mixed Colors. This splendid new class produces flowers of immense size and of the most varied and attractive markings and colors, each petal bearing a blotch that almost entirely covers it, so as to resemble the Lady Washington Geranium. The plants are of sturdy habit, and the floweis are borne well above the leaves, showing them to the best advantage. This is the most striking and showing pansy introduced for years. Pkt., 15c. 


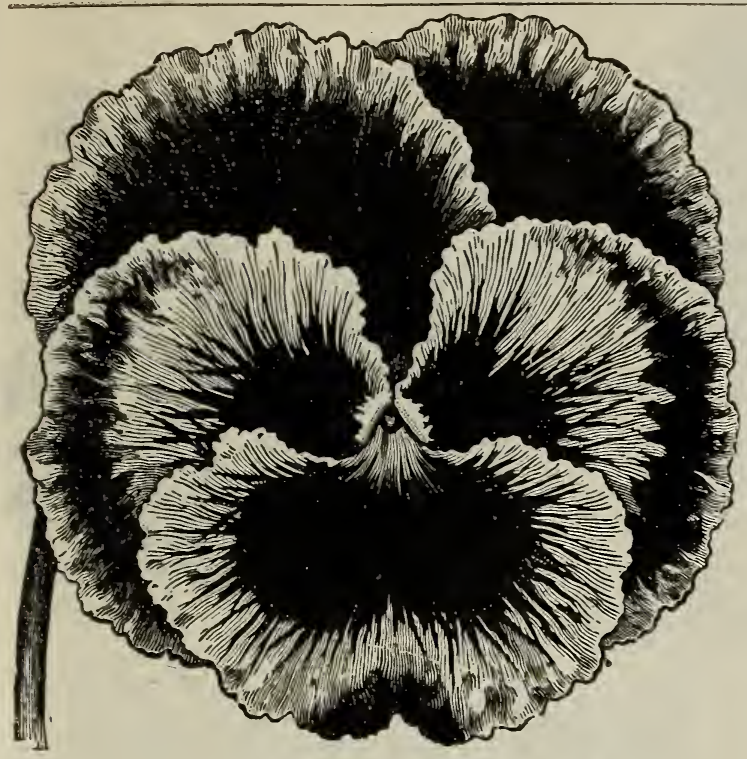

LEONARD'S GIANT FIVE=SPOTTED PANSY.

PANSIES.-Continued.

Giant Fancy Striped. An infinite variety of beautiful colors, curiously striped and flamed. Our stock is very select. 'The plants are vigorous and compact in growth. Immense flowers of fine form and texture, rich and velvety. Pkt., 10c.

Aurora. Flowers large. Color pure white without blotches. Pkt., 10c.

Mad. Perrett. Edge of petal is frilled. The colors are of dark wine, pink and red, beautifully veined, and all with a white margin. Pkt., 10c.

Cassier. This is a very fine mixture of pansies marked with three or five blotches on rich backgrounds The flowers are very large, round and borne on stiff stalks emerging from bushy compact plants. This mixture contains a great many red shades. Pkt., 10c.

Peacock. Very striking. Form and substance perfect. Upper petals beautiful ultramarine blue, resembling in shade the peacock feather. Lateral and lower petals are of a deep claret, margined white. Pkt., 10c.

Masterpiece. This strain comes nearer to the Double Pansies than anything ever introduced under that name. In reality the number of petals is the same as that in other pansy flowers, but they are crimped and curled in such a fashion that the flowers appear double. The flowers are of enormous size, often three inches across, and the color variations and combinations are odd and striking. Pkt., 10c.

\section{PETUNIA.}

For outdoor decoration or house culture, few plants are equal to this class. They commence to bloom early, and continue to flower through the summer. Give them a rich soil and a sunny place.

Double Mixed, Large Flowering. Flowers twice the size of the ordinary strain, and the most beautiful colors. Produce a larger per cent of double than most strains. Pkt., 25c.

Single Large Flowering. Mixed, all colors. Pkt., 10c.

Large=flowering, Fringed Superbissima Crimson. The distinguishing characteristics of the Superbissima class of Petunias is the large, delicately veined throat. This fine feature has now appeared among fringed varieties, adding quite a unique beauty which will delight all lovers of Petunias. Pkt., 25c.

Petunia, Hybrid Snowball. A very dwarf variety, with beautiful, large, satiny-white flowers, covering the plant with bloom. Pkt., $15 \mathrm{c}$.
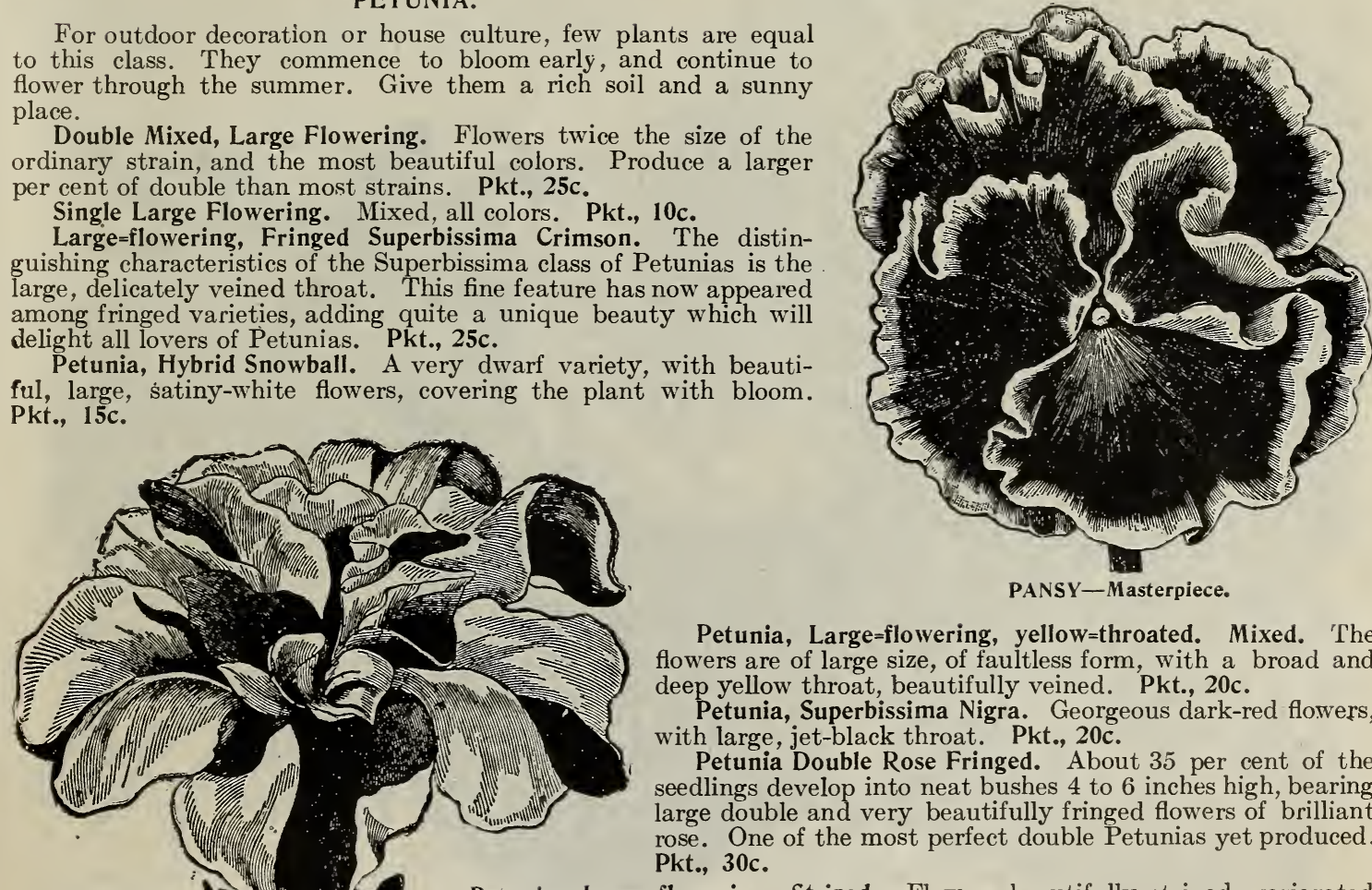

Petunia, Large=flowering, yellow=throated. Mixed. 'The flowers are of large size, of faultless form, with a broad and deep yellow throat, beautifully veined. Pkt., 20c.

Petunia, Superbissima Nigra. Georgeous dark-red flowers, with large, jet-black throat. Pkt., 20c.

Petunia Double Rose Fringed. About 35 per cent of the seedlings develop into neat bushes 4 to 6 inches high, bearing large double and very beautifully fringed flowers of brilliant rose. One of the most perfect double Petunias yet produced. Pkt., 30c.

Petunia, Large=flowering, Striped. Flowers beautifully striped, variegated and spotted. Remarkable for rich colors and large size. Pkt., 10c.

Petunia, Fringed. Satiny-white blotched with purple crimson. Pkt., 15c.

Petunia, Fringed and Veined. Rose veined with black. Pkt, 15c.

Petunia, Fringed. Largest flowered, mixed in great variety of colors. Pkt., 15c.

Petunia, Fine Mixed. Pkt., 3c.

Petunia, Giants of California. Remarkably fine. Flowers very large, in every conceivable shade of crimson, white, violet, lavender, etc. Pkt., 15c.

Petunia, Howard's New Star. Dark crimson maroon with rich velvety texLARGE FLOWERING DOUBLE PETUNIA

ture and clearly defined five-rayed star of blush white. Over 80 per cent of the plants from seed will produce the star markings. Others with veined and feathery markings on dark or light ground are not less beautiful. Remarkably free flowering, 2 packages for 25 c. Pkt., 15c. 


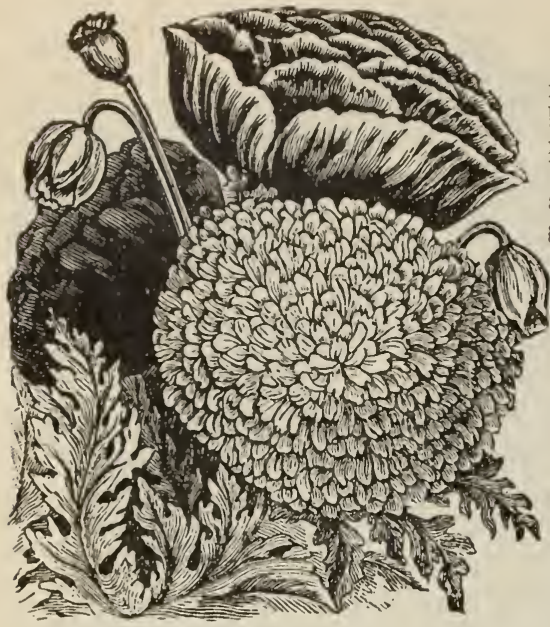

POPPY.
PASSIFLORA.

(Passion Flowers.)

Passiflora Coerulea. The most beautiful and remarkable variety grown, producing rich, green foliage and sky blue flowers, followed in the golden fruit. Pkt., $5 \mathrm{c}$. POPPIES.

Showy, large, brilliant colored flowers, growing freely in any garden soil. Produce a fine effect in clumps Golden Gate. Recall to mind every color you have seen in poppies then imagine every conceivable combination of colors and you will wonderously varied beauty of the new Golden Gate Poppies. Pkt., 5c.

Finest Mixed. All colors and varieties. Pkt., 5c. Snow Drift. A grand variety. The large pure white flowers are perfectly round and double. Pkt., 5c.

Shirley. The absence of black gives them their wonderful light, bright tissue paper-like appearance. The colors range from purest white, through pinks of all shades, to glowing scarlet, but a scarlet without black. Pkt., 5c.

The Mikado. Of pure white and brilliant crimson

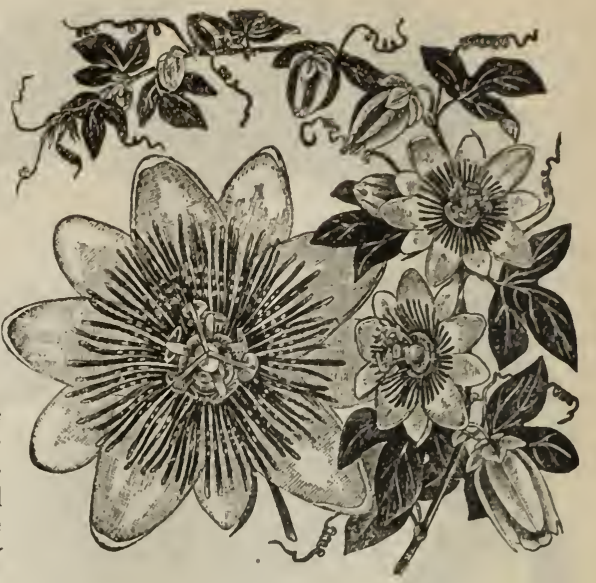

PASSIFLORA.

scarlet. Large double flowers of quaint, artistic beauty, with petals deeply cut and fringed. Pkt., 5c.

Fairy Blush. The immense globular flowers are perfectly double, and measure from ten to thirteen inches in circumference. The petals are elegantly fringed and pure white, except at the tips, where they are distinctly colored with rosy cream. Pkt., 5 c.

Poppy Carnation Flowered. Very fine, double fringed flowers, all colors. Pkt., $5 c$.

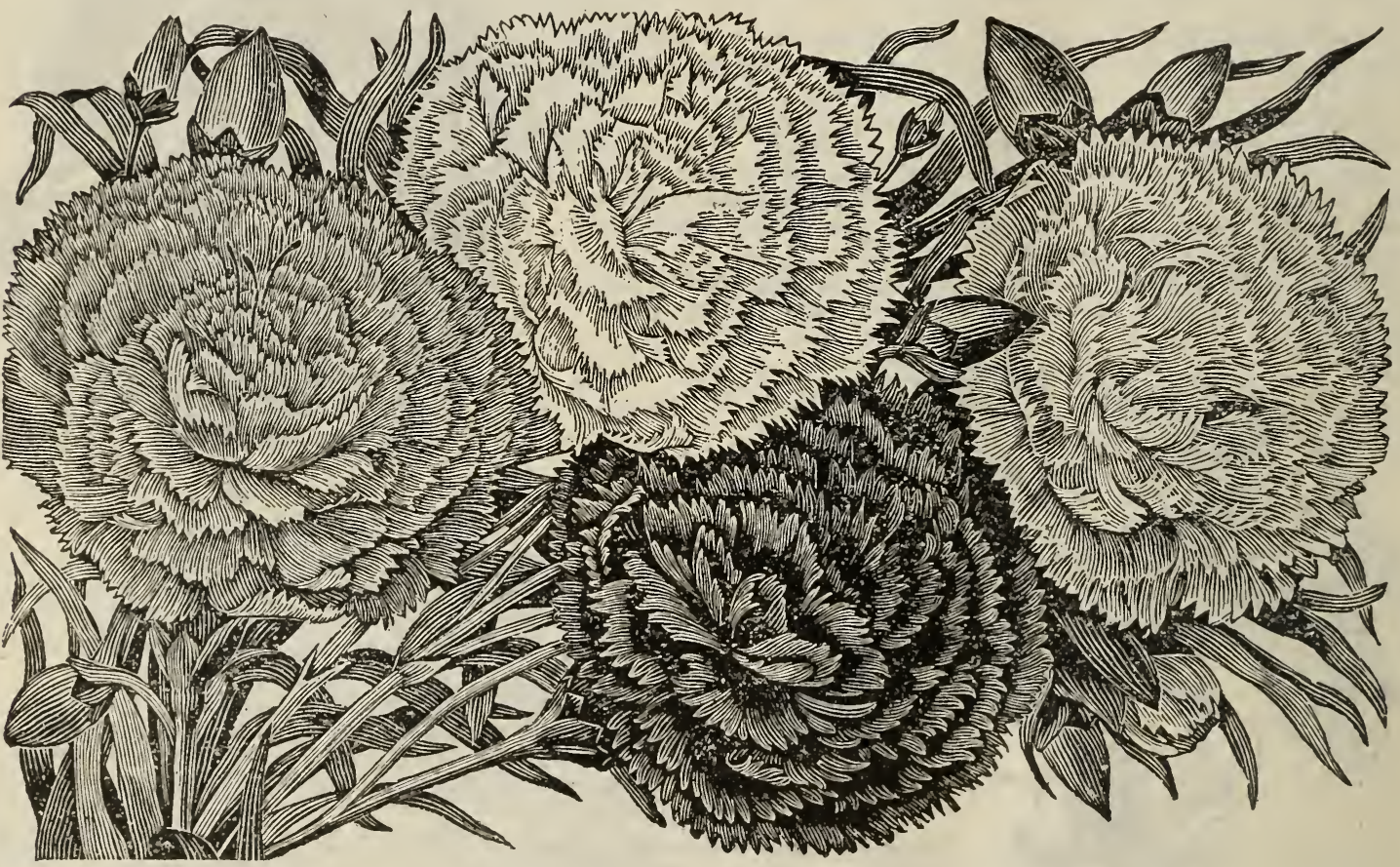

DOUBLE ANNUAL PINKS.

These flowers are without a superior among annual garden plants. Bloom continually all'summer long, and are most beautiful and lasting cut flowers. Of easy culture and bloom the first year from seed. Very fragrant.

Double Chinese Pinks. Flowers large and double. This beautiful variety does well anywhere. Pkt., 5c. Double Heddewegii. Large flowers, beautiful rich colors, finely marked. Pkt., 5 c.

Double Diadem Pink. Of dwarf, compact habit, of various tints of rose, maroon and purple. Pkt., $5 \mathrm{c}$. Double Japan Pinks: This is a strain superior to any we have previously had.

Double Imperial Pink. Mixed. Pkt., 5c.
Eastern Queen. Beautifully marbled; the broad bands of rich mauve upon the paler surface of the petals are very striking and pretty. Pkt., 5c.

Crimson Belle. Rich, vivid crimson-like color; flowers of extraordinary size and substance, evenly and finely laciniated. Pkt., 5c.

Snow Queen Pink. This is an extra fine selection of the large flowering double White Japan Pink, the very best strain we have ever seen. Pkt., $5 \mathbf{c}$. 


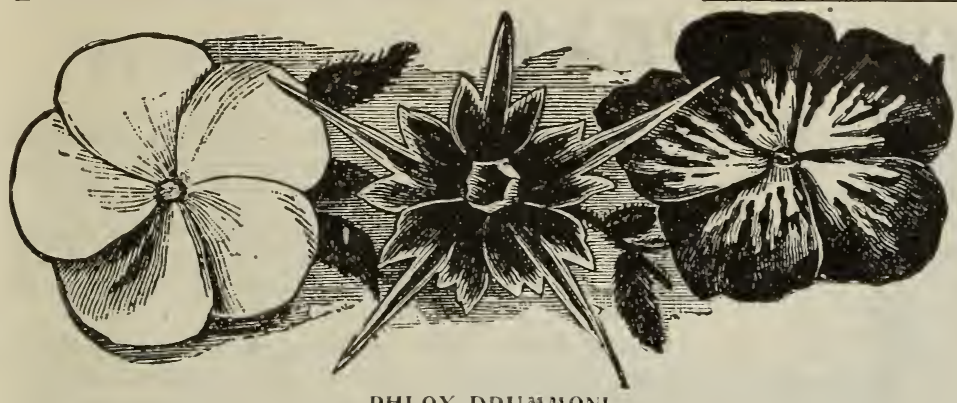

PHLOX DRUMMONI.

NEW STAR PHLOX. (Cuspidata.) (See Cut.)

The flowers with their long pointed petals and broad white margins, having a beautiful, star-like appearance. Many and wonderfully brilliant colors .05

HARDY PHLOX. (Phlox Decussata.)

These rank among the finest herbaceous plants for beds and borders. Magnificent, large waxy flowers of lovely shades of color. Strong bushes, two to three feet high. Pkt.

\section{PRIMULA.}

Beautiful low-growing spring-flowering plants, for borders or pot culture. The flowers are borne in clusters on stalks 4 to 8 inches high. The English Primrose is perfectly hardy; other varieties should be protected over winter.

Primula Sinensis. (Chinese Primrose.) Splendid mixed....................15 Primula Vulgaris. (English Primrose.) The old

favorite yellow Primrose........... .05

Primula Elatior. Mixed. (Polyanthus.) Early

blooming, for spring beds or pot culture. $\quad .10$

PERILLA. (Nankinensis Atropurpurea Laciniata.)

Ornamental foliage plants similar to Colaus. Fine for bedding with silver-leaved plants. Foliage metallic bronze; same culture as for Coleus. Half hardy annual. Pkt........... .05

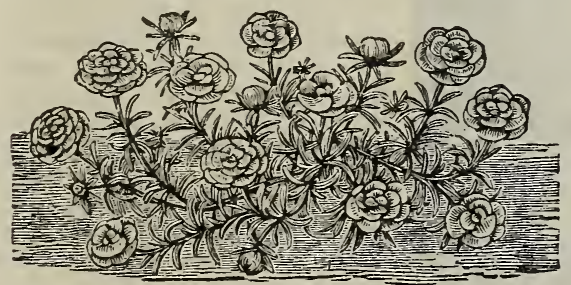

DOUBLE PORTULACA.

PORTULACA.

Sow early, in warm, light soil, and thin plants to 4 inches.

Portulaca Single. Mixed. Per Pkt.......... . 05 Portulaca, Large flowered. Double. Pkt.......

\section{RODANTHE.}

A beautiful and charming everlasting flower. The flowers when gathered as soon as opened, are very desirable for winter bouquets, retaining their brilliancy for months.

Rodanthe Maculata. Single mixed.......... .05

RICINUS. (Castor Oil Plant.)

A highly ornamental, half-hardy annual, growing from 4 to 6 feet high, presenting quite a tropical appearance, select warm dry soil and plant 6 feet apart.

Ricinus. Zanzibariensis (Zanzibar Castor Beans.)

Very showy, with gigantic leaves which range from. Jrilliant coppery-bronze to light and dark green; the ribs also are of bright colors, making a beautiful contrast with the leaves. 15 seeds..........., ,05
PHLOX DRUMMONDII.

In this great variety of rich colors, probably the most brilliant of all annuals. Fine for bedding, making a dazzling show throughout the entire season.

Phlox Drummondii. Mixed Colors, per

1 oz., 15c.; oz., 50c.; pkt., 5c.

LARGE FLOWERING VARIETIES.

Magnificent class. Flowers as large as those of the perennial Phloxes.

White..... .10 Yellow .... . .10

Deep Purple. .10 Large Flower=

Bright Scar $=$ ing Mixed.

$$
\text { iet....... } \quad .10
$$

One package each of the four named varieties for $25 \mathrm{c}$. DWARF VARIETIES.

Fireball. Very brilliant $\ldots \ldots \ldots \ldots \ldots \ldots \ldots . .08$ Snowball. Fine white. $\ldots \ldots \ldots \ldots \ldots \ldots \ldots \ldots \ldots \ldots \ldots .08$

Heynholdi. Mixed. Fine for pot culture..... .05 FIMBRIATA

Petals toothed, beautifully fringed and margined with white. Mixed ....................10

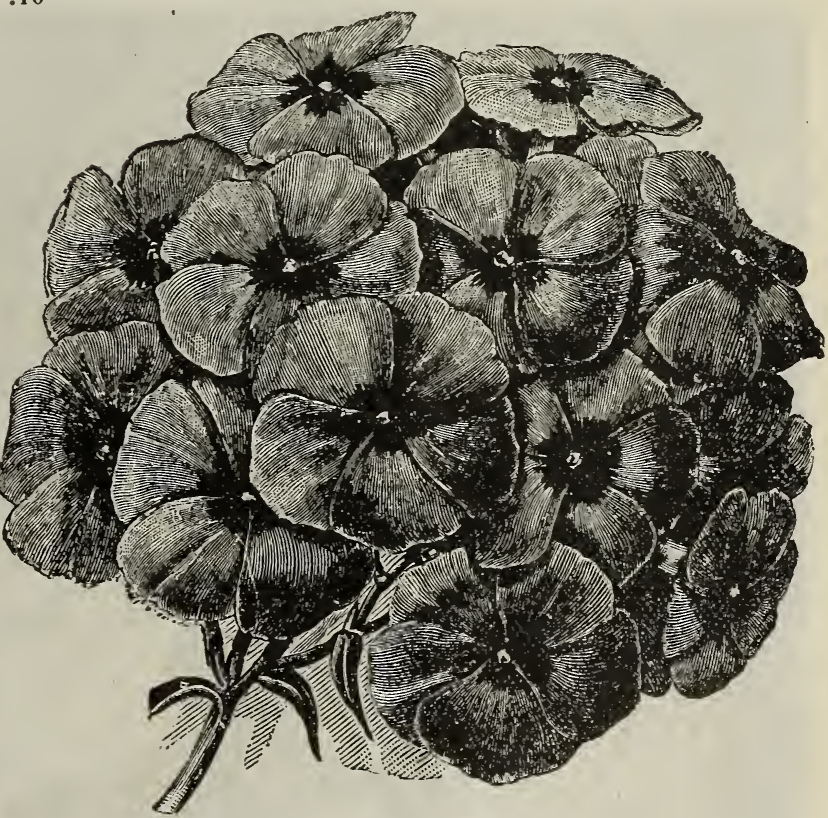

LARGE FLOWERING PHLOX.

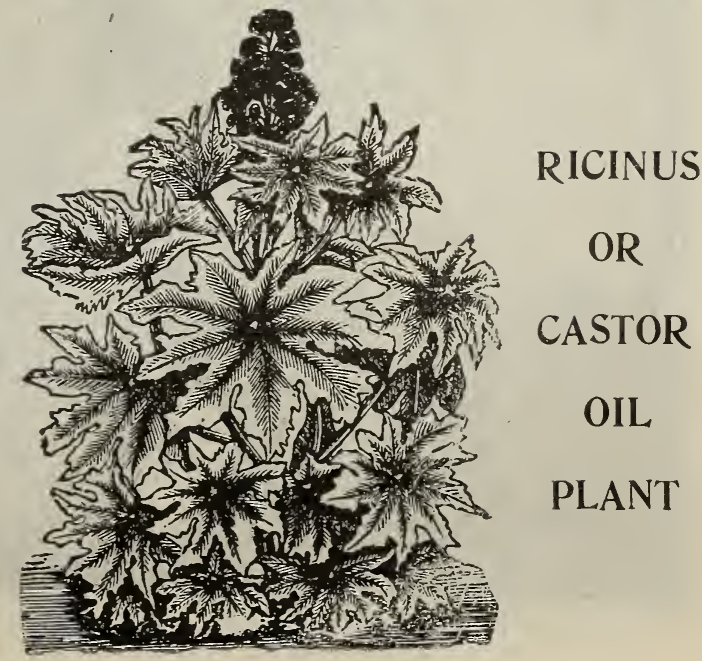




\section{SWEET PEAS}

Through the skill of specialists the Swect Pea has become a much larger and lovelier flower than before it became so popular. The plants are more robust, dwarf, branching, and bloom earlier and more freely, some varieties showing 3 to 4 blooms on a stem. Many new colors, deep, dark, brilliant, and delicately lovely, have appeared in the blossoms, often in indescribable combinations. There are flowers, too, of quite distinct shapes, some of which are a great inprovement upon the Sweet Pea of the old type. Our present list contains all the best kinds introduced to date.

King Edward VII. A true giant-flowered variety with long, strong stems and growth, with no inclination to burn in the sun. A fine variety, much brighter than either Mars or Salopian; in fact, the best dark red in existence. It is one of Eckford's finest sweet peas. Fkt., 5c.

Gladys Unwin. Has a very large and bold flower, not hooded, but with a very striking upright crinkled

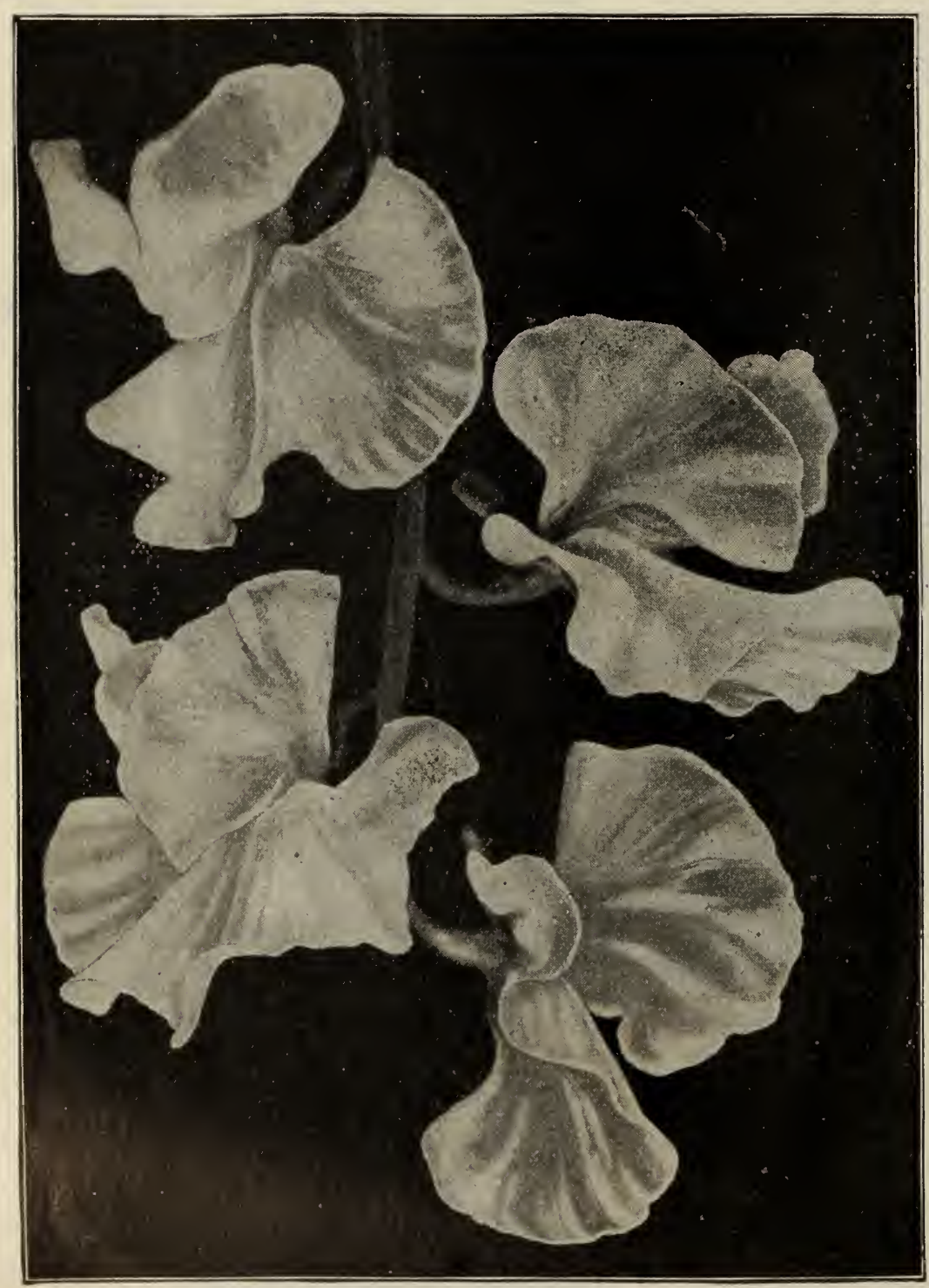

COUNTESS SPENCER. or wavy standard and broad wings. Color, a pale rosy pink. A striking feature is that about 75 per cent of the long flower stems are with four blooms, which is a most unusual thing in sweet peas. Pkt., 5c.

Helen Lewis. 'This is a selection from Countess Spencer, with the same large flowers and wavy standards; in colors a brilliant orange-rose, eclipsing all other of this shade.' Pkt., 10c.

Evelyn Byatt. The richest sweet pea yet introduced. It may be termed a self gorgeous, having a rich orange-salmon standard, with falls or wings of a trifle deeper color, giving a rich, fiery orange or deep sunset color to the whole flower, very striking and unique. Pkt., 10c.

Janet Scott. Received award of merit at the great London Show of The National Sweet Pea Society in 1904. The unusual size of the wings, in connection with the large substantial hooded standard, give the flowers an appearance of enormous size. The flowers are rich pink, deeper and richer than Katherine Tracy, and are generally borne three on a stem. Pkt., 5c.; oz., 10c.; 2 ozs.s 15c.; $\frac{1}{4}=1 \mathrm{~b} ., 25 \mathrm{c}$; 1 1b., $75 \mathrm{c}$.

Countess Spencer. Here we have a new and distinct type and form in Sweet Peas. The flower stems are unusually long and the flowers are so set on the stem that there is a graceful fluffiness to a bunch of them in distinct contrast to the ordinary kinds of Sweet Peas. So far but a few colors have developed in this type and some of thase sport or change more or less in flowering. The wings and standards of the flowers are very large, and its graceful form with the immense size make it certain to supersede all older kinds of Sweet Peas, as fast as standard colors appear and become fixed. In our mixture of this new class will be found deep pink, light pink, orange pink, white with pink edging. Every lover of Sweet Peas should plant our Countess of Spencer mixture. Pkt., 10c.; oz., 20c.; 2 oz:., 30c.; $\frac{1}{4}$ lb., 50c.

White Spencer. Produces in the greatest profusion flowers of enormous size that are absolutely pure white. The standard is decidedly waved, crinkled and fluted. The standard measures 13 -inch across by $1 \frac{3}{8}$-inch in depth. The wings are fully 1-inch wide. The flowers are borne three and four to the stem, the stems measure from 12 to 15 inches in length. The vines are most vigorous in growth and are nearly covered with bloom, while the flowers retain their enormous size thoughout the season. Of fine substance, the magnificent flowers are unsurpassed for cutting and for keeping after being cut. Pkt. 10c.; oz., 20c.; 


\section{SWEET PEAS-Continued.}

STRIPED AND VARIEGATED.

America. The most brilliant of the red striped sorts. White ground, striped crimson scarlet. Large fine flower. Pkt., 5c.; oz., 10c.

Aurora. Standard and wings flaked and striped on a white ground with bright orange salmon. Pkt., 5c.; oz., 10c.

Gray Friar. White ground, marbled and dotted with heliotrope and purple. Pkt., 5c.; oz., 10c.

Juanita. White, with stripes and dashes of delicate lavender. Large and splendidly formed. Pkt., 5c.; oz., 10c.

Mrs. Joseph Chamberlain. Flowers are of fine form and large size, heavily flaked and striped with deep, clear rose Pkt., 5c.; oz., 10c.

Senator. The finest dark striped flower. White ground, almost entirely covered with heavy stripes of brown and chocolate. Pkt., 5c.; oz., 10c.

Columbia. White ground, suffused purple and penciled pink. Pkt., 5c.; oz., 10c.

LIGHT PINK AND ROSE.

Eliza Eckford. Large flower rosy pink over white. Delicate and very beautiful. Pkt., 5c.; oz., 10c.

Katherine Tracy. Considered the best pink. The color is soft but brilliant in both wings and standards. Stands the hot sun better than any other pink. The

long stiff stems make it especially fine for cutting. Pkt., 5c.;oz., 10c.

Lady Beaconsfield. Standards are salmon pink. Wings primrose yellow; large and handsomely formed. Pkt., 5c., oz., 10c.

Lovely. Soft shell pink; large flowers, often four on a stem.

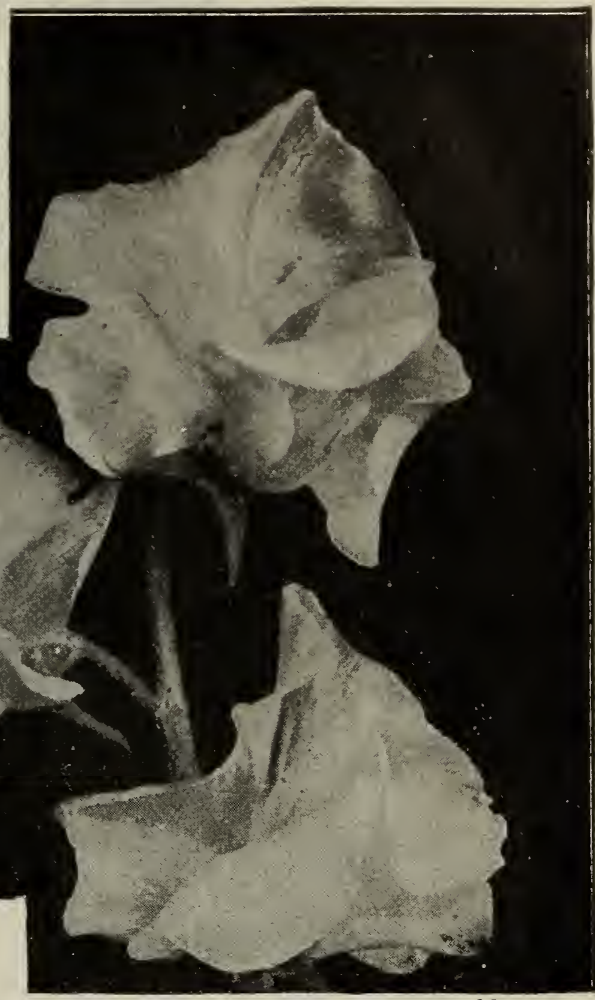

WHITE SPENCER: See page 90. Pkt., 5c.; oz., 10c.

Duchess of York. White, suffused with a delicate pink. Pkt., 5c.; oz., 10c.

Mrs. Sankey. A very light pink which fades to white as the flower grows older. Pkt., 5c.; oz., 10c.

Prima Donna. A brilliant soft pink. Large and perfect flower. Pkt., 5c.; oz., 10c.

Ramona. Creamy white ground, delicately striped and splashed pale pink. Pkt., 5c.; oz., 10c.

Venus. Lovely salmon; buff shaded, rosy pink. Pkt., 5c.; oz., 10c.

Apple Blossom. Bright rosy pink, beautifully blended; white. Pkt., 5c.; oz., 10c.

Her Majesty. Large Hooded flowers of a beautiful rose pink. Pkt., 5c.; oz., 10c.

Lady Mary Currie. A deep orange pink. Brilliant color. Pkt., 5c.; oz., 10c.

Lady. Penzance. Standards orange pink; wings, deep pure pink. Pkt., 5c.; oz., 10c.

Ovid. A rich rose color, overlaid with a darker shade. Pkt., 5c.; 0z., 10c

Peach Blossoms. A very large flower, having a warm yellowish pink standard, and wings of a lighter, softer shade. Pkt., 5c.; oz., 10c.

Royal Robe. Bright rose pink. Pkt., 5c.; oz., 10c.

Royal Rose. One of the largest and finest formed flowers yet introduced. Standard rose pink, wings a shade lighter. Pkt., 5c.; oz., 10c.

Extra Early Blanche Ferry. Two weeks earlier than any other sort. Wings are nearly white, while the standards are a deep rose pink Hardy, vigorous and a dwarf grower; Pkt., 5c.; oz., 10c.

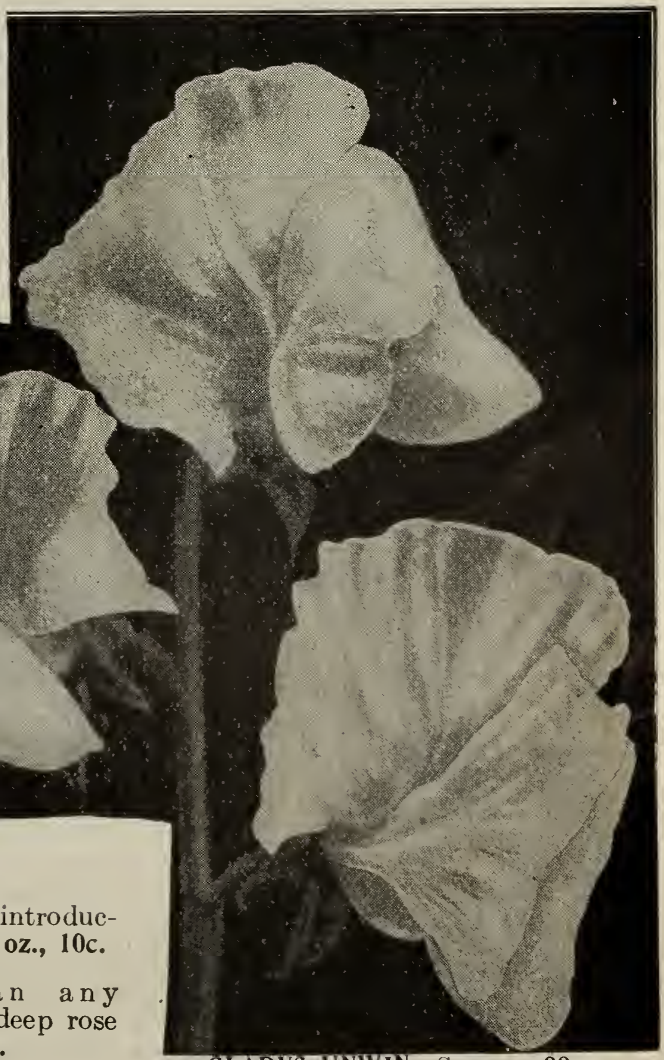

GLADYS UNWIN. See page 90. 


\section{SWEET PEAS - Continued}

DARK BLUE AND PURPLE.

Countess of Cadogan. A very long stemmed variety bearing three and four flowers on each stem. A beautiful blue shade a little darker than navy blue. Pkt., 5c.; oz., 10c.

Captain of the Blues. Flowers large and expanded. Standard bright purple blue. Wings expanded and a lighter blue. Pkt., 5c.; oz., 10c.

Indigo King. Standard, a very rich purple. Wings bluer than the standard. Pkt., 5c.; oz., 10c.

Navy Blue. A true blue, quite distinct in color. Pkt., 5c.; oz., 10c.

\section{CRIMSON.}

Mars. Bright crimson. Large and gorgeous flowers. Pkt., 5c.; oz., 10c.

Ignea. Intense crimson, but does not stand the hot weather well. Pkt., 5c.; 0z., 10c.

Salopian. One of the most brilliant sorts yet introduced. The flowers are of faultless form, large and a rich, brilliant cardinal red. Pkt., 5c.; oz., 10c.

\section{YELLOW.}

Coquette. Standard, shaded light blue on primrose ground. Wings clear primrose. Fine large flowers. Pkt., 5c.; oz., 10c.

Mrs. Eckford. A delicate primrose yellow. Flowers large, of good substance and perfect form. Pkt., 5c.; oz., 10c.

Primrose. A light primrose. Pkt., 5c.; oz., 10c.

Stella Morse. Large flowers of the finest form and a peculiar warm salmon pink. Pkt., 5c.; oz., 10c.

Golden Gleam. 'The best of the yellows. Large and perfect. Pkt., 5c.; oz., 10c.

\section{CLARET}

Duke of Clarence. Deep rosy claret; large and of fine form. Pkt., 5c.; oz., 10c.

\section{WHITE.}

Blanche Burpee. The finest White yet introduced. Flowers pure white; immense size. Profuse bloomer. Pkt., 5c.; oz., 10c.
Emily Henderson. Flowers large, pure satin white on long stiff stems. Free and persistent bloomer. Pkt., 5c.; oz., 10c.

\section{MAROON.}

Black Knight. The darkest sharle of maroon. Pkt., 5c.; oz., 10c.

Boreatton. "One of the darkest and richest colored satin-like maroon. Self-colored. Pkt., 5c.; 0z., 10c.

Monarch. Standard, large, fine form of violet maroon. Wings expanded, very large, similar color, but having a bluish tint. Pkt., 5c.; oz., 10c.

Stanley. The darkest of all sweet peas. A fine, bold flower. Color a deep maroon. Pkt., 5c.; oz., 10c.

Shahzada. Rich, very dark maroon standard and deep violet wings. Pkt., 5c.; oz., 10c.

Waverly. The wings and standard are a beautiful blending, rose pink and lavender blue shades. Pkt., 5c.; oz., 10c

\section{SCARLET.}

Brilliant. Rich crimson scarlet. Stands the summer heat better than any other sort. Pkt., 5c.; oz., 10c.

Firefly. Intense scarlet. Of good size and form. Pkt., 5c.; oz., 10c.

Invincible Scarlet. Bright scarlet. Pkt., 5c.; oz. $10 \mathrm{c}$

Princess Victoria. Standard bright scarlet. Wings rosy mauve. Pkt., 5c.; oz., 10c.

\section{LAVENDER AND LIGHT BLUE.}

Butterfly. Standard a combination of shades of violet and lavender. Wings white shaded and edged blue. Pkt., 5c.; oz., 10c.

Countess of Radnor. A beautiful shade of lavender.

Pkt., 5c.; oz., 10c.

Dorothy Tennant. Flowers warm violet or mauve. Very large and finely formed. Pkt., 5c.; oz., 10c.

Lottie Eckford. White, lightly suffused with blue. Wings deeper blue. Pkt., 5c.; oz., 10c.

Maid of Honor. White, edged with blue. Has a very handsome appearance. Pkt., 5c.; oz., 10c.

\section{CUPID SWEET PEAS.}

Alice Eckford Cupid. Creamy pink standard; wings white flushed pink.

America Cupid. Striped blood red and white.

Apple Blossom Cupid. A charming combination of pink and white.

Beauty Cupid. Delicate rose color shading to white, suffused rosy carmine.

Blanche Ferry Cupid. Standard bright rose pink, wings blush-white

Blue Cupid. Violet purple approaching blue.

Boreatton Cupid. Rich maroon color, with darker veinings

Chamberlain Cupid. Giant flowers, striped pink on white.

Mixed "Spencer Hybrid" or Giant “Orchid=Flowered" Sweet Peas. This sensational new type originated in England. The plants are of healthy, vigorous growth producing in greatest prof usion long, strong-stemmed flowers

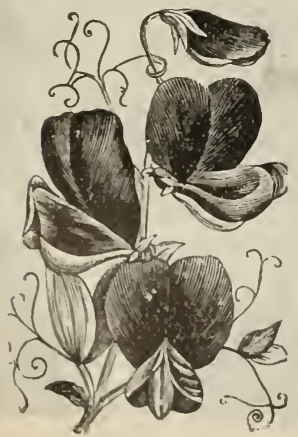
of splendid substance, perfect form and truly gigantic size, often measuring 2 inches and over across. Wings large and gracefully poised; the standards boldly upright, facing all one way, round and delicately waved. This mixture is composed of Spencer types only and contains new varieties not yet fixed and in commerce. Large pkt., 10c.; oz. 20c.; $\frac{1}{4}$ lb., 50c.; lb., $\$ 1.60$.

\section{SPECIAL MIXTURES SWEET PEAS.}

Leonard's Choicest Mixed.

Leonard's Florist's Mixed.

L.eonard's Named Sorts Mixed.

Fither of the above splendid mixtures, Per oz., 5c.; 1 1b., 15c.; lb., 50c. Postpaid. 5 lb. or more, by Express, $40 \mathrm{c}$ to $\mathrm{lb}$.

Choice Mixed. This is grown in mixture of many old and new varieties. Per pkt, 5c.; 0z., 10c.; ${ }^{1}$ lb., 15c.; per lb., 40c., postpaid. By express, 30c per lb.

Cupid Sorts, Mixed, pkt.. 5c.; oz., 10c.; 1 lb., 15c.; lb., 50c, 


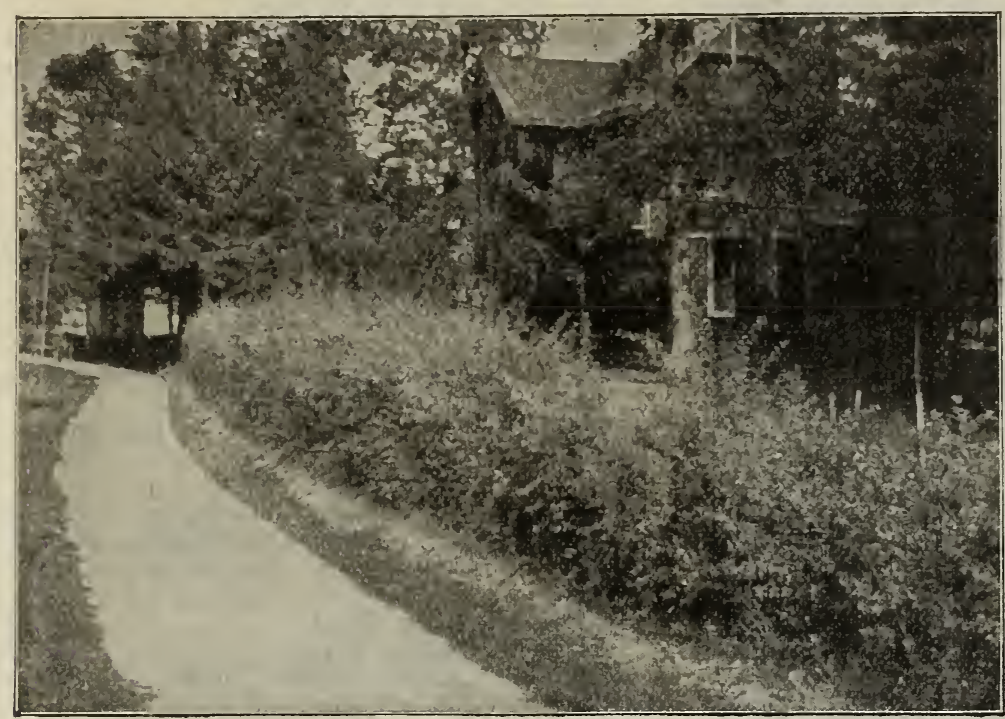

A BORDER OF SALVIA,
SALVIA.

Very ornamental plants, 2 feet high, producing tall spikes of gay flowers. Sow early in hotbed, or in pots in the house, and transplant 2 feet apart. Half hardy.

Salvia Coccinea. Splendid Scarlet. 05

Salvia Bonfire. Fine for bedding; grows about $2 \frac{1}{2}$ feet high, forming handsome globular bushes, producing long spikes of brilliant, dazzling scarlet flowers. Blooms the first year ................. 10

Mixed. All colors. Pkt., 5c. SALPIGLOSSIS, NEW EMPEROR.

This new variety forms only one leading stem which bears on its summit a bouquet of the most beautiful flowers, every one of them richly veined with gold, and much larger even than those of the grandiflora type. ............. .10 SALPIGLOSSIS GRANDIFLORA

Flowers 2 to 3 inches in diameter, vividly marked, spotted and striped on ground colors of deep blue, rose, violet, yellow, reddish bronze,purple etc. In rich coloring they vie with Orchids in mixed colors..... .05
SANVITALIA.

Beautiful dwarf-growing plants densely covered with erfectly double golden flowers, of great value for beds and borders. .05

\section{SCHIZANTHUS. (Poor Man's Orchid.)}

Schizanthus. Dwarf, large-flowering plants, grow about 12 inches in height, literally covered with large, beautiful orchid-like flowers, which are exquisitely marked and range in all shades from white to pink and blue, spotted with red, yellow and brown, mixed. . . .15

\section{SILENE. (Catchfly.)}

Hardy plants flowering in great profusion throughout the summer. The Annual Silenes can be specially recommended for autumn sowing, as they will then produce a most effective show in the spring garden.

Silene Mixed.

Silene Bijou. Flowers extra double, of a brilliant salmon rose ......................15

Silene, Asterias Grandiflora. Hardy perennial variety, bearing in great profusion upright flower stalks, each carrying a large globular head of crimsion scarlet flowers. ......................... .15

\section{SMILAX.}

No climbing plant surpasses this in beauty and grace of foliage. Exfensively used for bouquet and floral decorations: 4 t

STOKESIA CYANEA. (Cornflower Aster.)

A rare and beautiful hardy perennial. The plant grows about 2 feet high, bearing from 20 to 30 handsome lavender-blue cornflower-like blossoms. In bloom from July till frost. 2 pkgs., 25 c............ 15

\section{STOCKS.}

Half-hardy annuals, producing splendid spikes of very rich and beautiful flowers of delightful fragrance. For early flowering sow early in spring in pots or in hotbed, and transplant one foot apart. Bloom from June until November.
Stocks, Princess Alice. Snow white. This variety, also known as "Cut and Come Again," and "White Perfection," grows about 2 feet high, is of very branching habit, and produces in great abundance very large, beautiful, pure white flowers, which are replaced as they are cut..................... .10

Stocks, Victoria, Ten Weeks. (Deep blood=red.) Every plant forms a perfect pyramidal-shaped bouquet, covered with beautiful, bright, fine double flowers . $\quad .10$

Stocks, Dwarf, German. Finest Mixed....... .05

Stocks, Ten Weeks. Double. Mixed........ .05 Stocks, Dwarf. Large=flowering. Finest Mixed. Very Double. One of the finest stocks in cultivation.......................... 10

\section{SWEET WILLIAM.}

Well-known, beautiful, hardy perennials, about 1 foot high, making a most splendid appearance in May and June.

Sweet William. Single. Mixed........... .05

Sweet William. Double. Mixed........... . 10

Sweet William, Auricular Eyed. . . . . . . . . . . .05

Sweet William Holburn Glory. A new magnificent strain with extra large flowers, the single blooms being larger than a 25 cent piece. This variety took the first prize at the Mass. Hort. Soc. the past season.

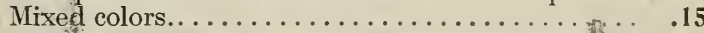
tit

\section{SUNFLOWERS.}

Valuable as a screen to hide unsightly places, and as a background for lawns. Hardy annual.

Double Chrysanthemum Flowered. A tall plant, growing seven feet high and blooming profusely all summer. Flowers are double, large, round, golden yellow, and resemble chrysanthemums. Pkt., 5c.

Globosus Fistulosus. Produces very large, exceedingly double flowers of bright yellow color: Plants about five feet high. Pkt., 5c.

Large Russian. A strong growing, single variety, about six feet high. The stalks are sometimes used for fuet. Pkt., 5c.; 1b., 20c. 


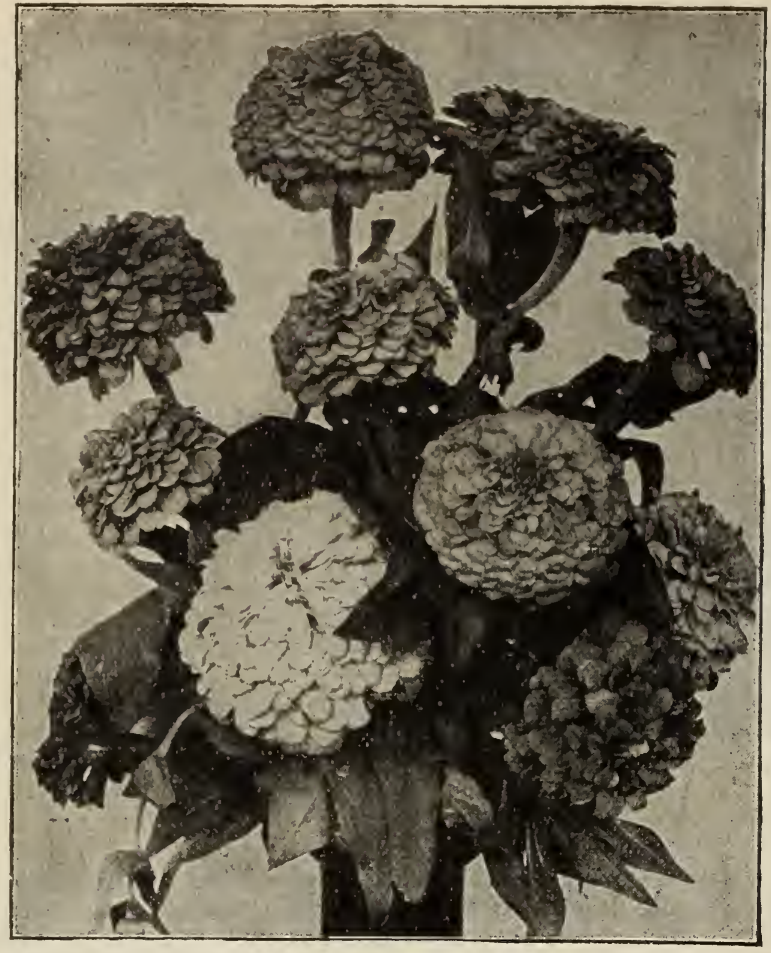

ZINNIA GRANDIFLORA.

ZINNIA. (Youth and Old Age.)

Splendid hardy annuals; succeeding well in any soil, and making a brilliant show. The same flowers will retain their beauty for weeks and a profusion will be produced until frost.

Zinnia. Elegans Grandiflora Plenissima. (New Giant Zinnia.) Extremely double, globe-shaped flowers, 5 inches in diameter, of striking and brilliant

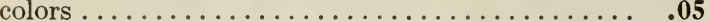

Zinnia. Grandiflora Plenissima Striped. Very showy and beautiful...................... .05

Zinnia. Double Giant. "Queen Victoria." Pure white, very double flower of beautiful shape..... $\quad .10$

Zinnia. Tall. Finest varieties double mixed.. $\quad .05$

Zinnia. Dwarf. Double White. Very desirable for its regularity of growth and beautifully shaped flowers. ..........................

Zinnia. Dwarf Double. Jacqueminot. Rich deep crimson scarlet .................... .I0

Zinnia. Double Lilliput. Mixed. Very compact, forming thickly branching little plants about a foot and a half high, which fairly bristle with very double flowers of every shade and color, and hardly exceeding a large daisy in size

Zinnia. Lorenz's Miniature. The smallest Zinnia in existence, growing only about 4 inches high. The mixture we offer contains the following colors: white, scarlet, crimson, purple, dark rose and yellow .... $\quad .10$

\section{ALL FLOWER SEEDS SENT POSTPAID ON RECEIPT OF PRICE}

Send us $\$ 1.00$ and select PACKETS to the value of $\$ 1.15$

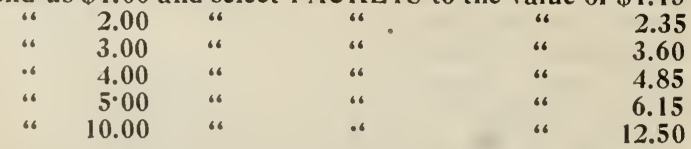

These Rates apply only to seeds in Packets, but not to seeds by Weight or Measure. No Discount can be allowed on Flower Seeds by Weight

\section{VERBENA.}

Mammoth Verbena. Obtained by selection of the largest and most striking flowers. Our strain is very fine. All colors mixed. Pkt., 10c.

Mammoth White. Large, very fine. Pkt., 10c

Scarlet. Very brilliant. Pkt., 10c.

Striped Varieties. Pkt., I0c.

Blue Varieties. Pkt.; 10c.

Red Varieties. Pkt., 10c.

Defiance. Very brilliant scarlet. Very. fine bedding variety. Pkt., 10c.

Fine Mixed. All colors. Pkt., 5c.

\section{VIOLET. (Viola Odorata.)}

Well known early spring blooming, fragrant flowers.

Single Blue. Very sweet scented blue flowers, Pkt., 5c.

\section{WALLFLOWER.}

Well-known half hardy perennials, blooming early in the spring and much prized for the delicious fragrance of their flowers. Should be protected in winter.

Wallflower, Single, Mixed............ .05

Wallflower, Double, Mixed ........... .10

Wallflower, Early, Single Annual. Sown in March in pots or liot-beds, will bloom from June until late autumn. Flowers of a beautiful orangered and very fragrant.

MIXED FLOWER SEEDS FOR WILD GARDENS.

A splendid mixture of beautiful, free-blooming, hardy flowers, which can be offered at a much less price than when sold in separate packages. Those who cannot give the constant care necessary for finely arranged flower beds, will find the "Wild Garden" a delightful substitute, with its constant and ever-varying bloom. Such a flower bed is a continual surprise and pleasure, as new varieties and the old garden favorites flower successively throughout the season. Thin out where plants are crowded and keep clear of weeds. Price, per $\frac{1}{2}$ oz., 20c.; Pkt., 5c.

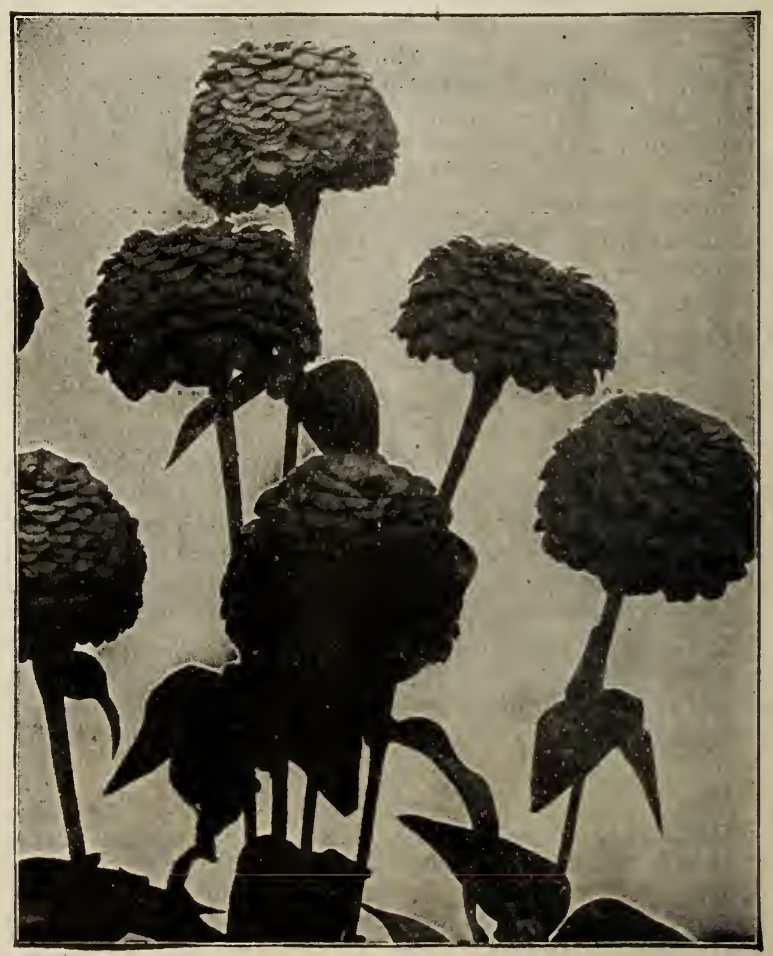

ZINNIA LILLIPUT. 


\section{SUMMER FLOWERING BULBS}

\section{GLADIOLUS}

These desirable bulbs should be planted in every garden. Claimed by many to be "the flower of all flowers. They contain every shade of color from the most brilliant and gorgeous to the softest and most delicate. The immense spikes of bloom, develop in the greatest perfection, if cut when the first four flowers open, and placed in water-they will last ten days.

Mixed, Large Flowering Bulbs. This mixture is composed of every color-white, pink, yellow, rose, scarlet, crimson, dark maroon, etc., beautifully marked and variegated. Prepaid, each 4c., per dozen, 30c.

Red Mixed. All shades. Prepaid, each, 5c.; per dozen, 40c.

White and Light Colors. Prepaid, each, 5c.; per dozen, $40 \mathrm{c}$.

Pink Shades. Prepaid, each, 5c.; per dozen, 40c.

Yellow Mixed. Prepaid, each, 5c.; per dozen, 40c.

\section{Giant=Flowered Gladiolus, Princeps.}

This magnificent new hybrid is an unusually healthy, robust variety, producing spikes often 3 feet long, carrying from 18 to 22 broad, round petaled, immense flowers, about 6 inches across, of perfect and open form and waxy substances. The coloring is glowing scarlet= crimson, enlivened below the throat by a large feathered white blotch sprinkled with scarlet. The spikes continue to lengthen and produce bloom for several weeks; often four of these glorious flowers are expanded at one time. and on account of the vigor of the plant, the tip buds develop almost as large and perfect flowers as those at the base, and frequently side growth and spikes are produced, thus lengthening the flowering period. Price each, 15 c., dozen, $\$ 1.50$.

\section{TUBEROSES}

Tall. Double. Three to five feet high, strong and free blooming. Prepaid, 6 for 20c.; per dozen, 35c.

Pearl. Larger, better and more flowers produced by this sort than the old variety. Stems short; from two to three feet high. Prepaid, 6 for $20 \mathrm{c}$; per dozen, 35c.

Excelsior Pearl. An improvement on the ordinary pearl; produces very heavy spikes of large double flowers. Prepaid, 5c. each; per dozen, 50c.

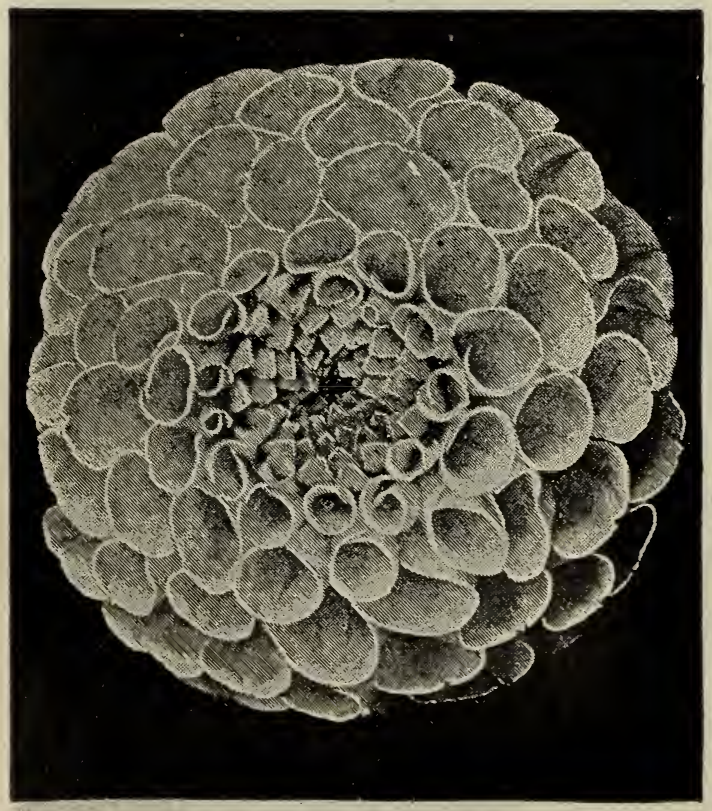

DAHLIAS

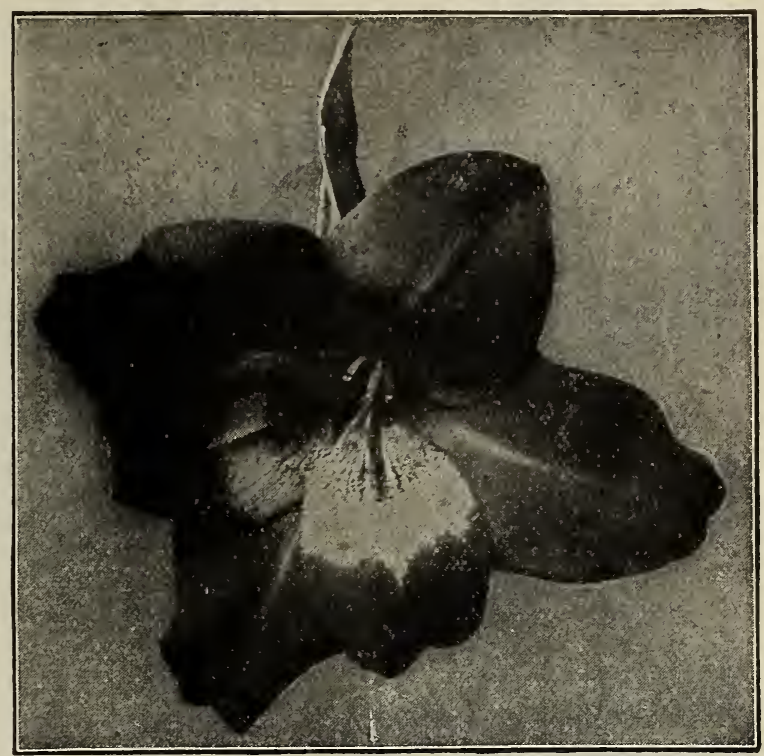

GLADIOLUS

DAHLIA:

The dahlia has always been a favorite for autumn flowering. The flowers are so symmetrical and perfect, and the range of colors so large and varied that they will always be popular where display is wanted. The roots are tender and easily injured by frost; they should be set out 3 feet apart, after all danger of frost is over, and during winter placed in a cool cellar, and not allowed to freeze. The plants should be supported by tying to stakes. Our collection of mixed dahlias is of the best, comprising all the positive colors, with their striking shades.

\begin{tabular}{|c|c|c|c|c|}
\hline \multicolumn{3}{|c|}{ Dahlias, double, pink. . } & EACH & DOZ \\
\hline 66 & "6 & scarlet. & $.15 c$ & 1.50 \\
\hline “ & “6 & white & $.15 c$ & 1.50 \\
\hline "6 & "6 & yellow. & $15 \mathrm{c}$ & 1.50 \\
\hline 66 & “ & mixed & $.15 c$ & 1.50 \\
\hline
\end{tabular}

\section{LARGE FLOWERING CANNAS.}

(Best Standard Sorts.)

Alphonse Bouvier. Large, brilliant scarlet. Rich and velvety.

Alsace. Very light, sulphur yellow changing to clear white.

Austria. The golden lily=flowered canna flowers, immense.

Burbank. Rich canary yellow, with carmine spots in the throat.

Chicago. Very showy. Brilliant orange scarlet. Free bloomer.

Egandale. Foliage dark greenish maroon. Flowers bright cherry.

Florence Vaughn. Flowers large, brilliant yellow, spotted scarlet.

Italia. The orchid=flowered canna.

Mme. Crozy. Scarlet, with a golden edge. A very popular sort.

Philadelphia. A bright glowing crimson. Rich and velvety. Early bloomer.

President Cleveland. Immense trusses. Flowers orange scarlet, and very large.

Queen Charlotte. Orange scarlet, with a very broad golden yellow edge.

Any Variety, Each, 10c.; per dozen, $\$ \mathbf{1 . 0 0}$. 


\section{SUMMER FLOWERING BULBS}

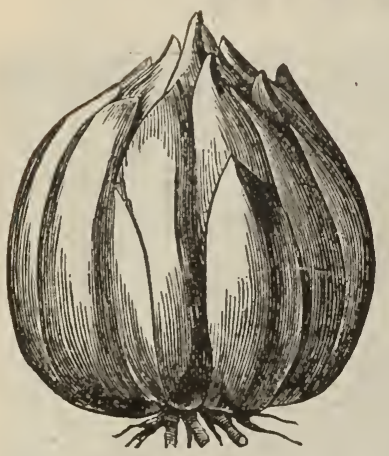

HARDY LILIES.

Lilium Auratum. The glorious gold banded Lily of Japan and one of the grandest plants in cultivation Each, 20c.; doz., $\$ 2.00$.

Lilium Longiflorium. The pure white flowers resemble the well known Bermuda Easter Lily and are very fragrant. Each, 15c.; doz., \$1.50.

Lilium Speciosum Album. Pure white flowers, with a greenish band through the center of each petal. Each, 20c.; doz., \$2.00.

Lilium Speciosum Rubrum. No words can overstate the brilliant beauty of these famous Japan Lilies. Each, 15c.; doz., \$1.50.

Lilium Tigrinum, Flore Pleno. (Double Tiger Lily.) This magnificent lily is of stately habit, bearing clusters of very large double flowers on tall, strong stems; color, bright orange red, spotted with black. Each, 15c.; doz., \$1.50.

Lilium Tigrinum, Splendens. (Improved Single Tiger Lily.) Has very large flowers of excellent form; color, orange salmon with dark spots. Each, 15c.; doz., $\$ 1.50$.

MADERIA VINE.

Tuberous rooted climber with glossy green leaves and delightfully fragrant, white blossoms. Sometimes called Mignonette Vine. It is of rapid growth, and from a few tubers vines will be produced sufficient to cover one side of a cottage in a single season. The tubers are tender and must be protected from frost during winter. Each, 5c.; doz., 50c.

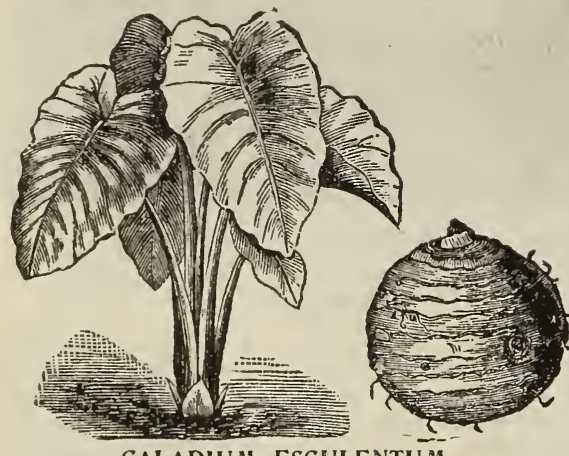

CALADIUM ESCULENTUM
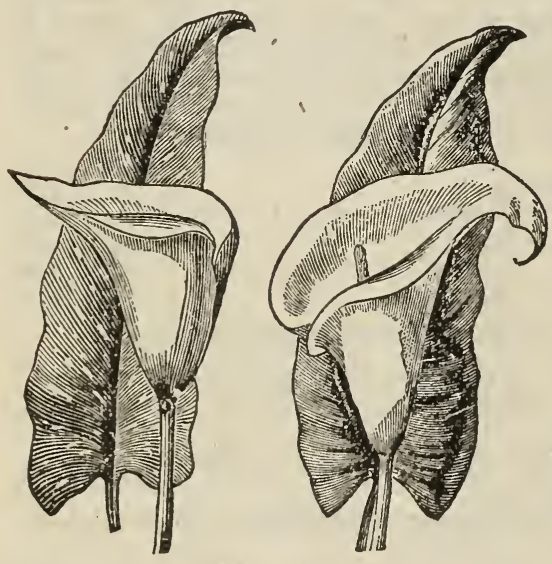

SPOTTED CALLA,

WHITE CALLA,

tain a height of twenty feet in one season. AMPELOPSIS.

Veitchii (Boston or Japan Ivy.) The leaves of this beautiful climber, resembling in shape the English ivy, overlap one another closely. changing in the fall to the most vivid autumnal tints. Extra strong field grown plants. Each, 20c.: by mail, 25c.

Quinquefolia. (Virginia Creeper.) Well known; leaves changing in fall to brilliant tints. Strong field grown plants. Each, 20c.; by mail, 25c.

\section{HYBRID LARGE FLOWERED CLEMATIS.}

Jackmanni. The best known of the fine perpetual clematis. Flowers intense violet purple.

Jackmanni Alba. White, strong grower.

Hybrida Sieboldi. Silvery lavender, a most beautiful shade.

iny Variety, Strong Plants. Each, 50c., postpaid.

Caladium Esculentum. Known as Elephant's Ears. One of the finest tropical plants which can be grown in the open air in the north. 列 or sheep manure in equal parts, with a sprinkling of sand commences, when, as the plants develop, they require an development but they must be shaded from bright sunlight. The bulbs we offer can be relied upon for satisfactory results.

First Size Bulbs, nine inches and over in circumference EACH DOZ. Second Size Bulbs, seven to nine inches in circumference $\ldots 20$ ć $\quad 2.00$ CALLA LILIES.

Ethiopica is the well known Egyptian Lily, or Lily of the Nile, with large white flowers, broad foliage, and it will prosper under adverse circumstances if given plenty of water. It is an excellent ntil the autumn.

Richardia Ethiopica or Egyptian Lily. Our Calla roots are large and fectly at home. Each, 25c.

Alba Maculata or Spotted Calla. This is a fine plant for summer. CINNAMON VINE.

A very pretty vine to or on a trellis. brilliant, ance of fragránt ceedingly quick grower having been known to atEach; 5c.; by mail, 10c.

.

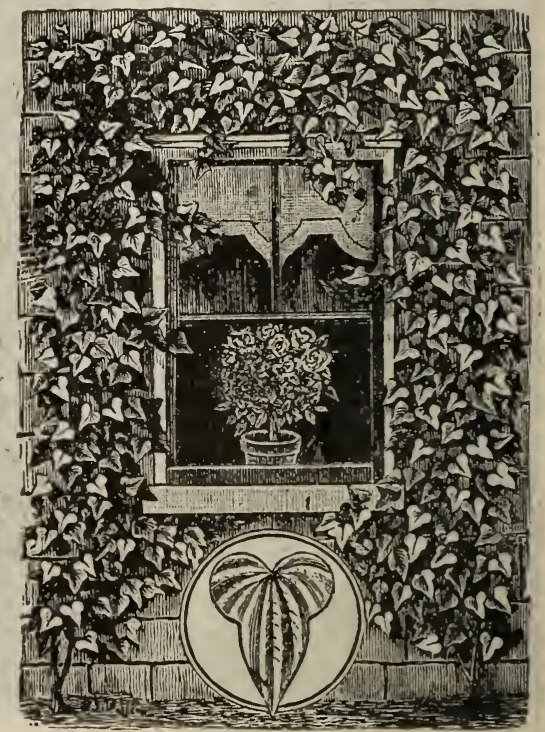

CINNAMON VINE. 
All Prices are Subject to Market Changes.

\section{POULTRY SUPPLIES.}

PEA SCREENINGS-IVHOLE AND SPLIT PEAS, ETC.

Chicken and Pigeon fanciers in the vicinity of Chicago are unanimous in their praise of Peas as a food for their fowls. They feed the Pea Screenings which contain both whole and split peas alone or by combining with regular mixed food. It can also be ground and fed as a mash with other grain and for this purpose is unsurpassed. Our large milling operations in Seed

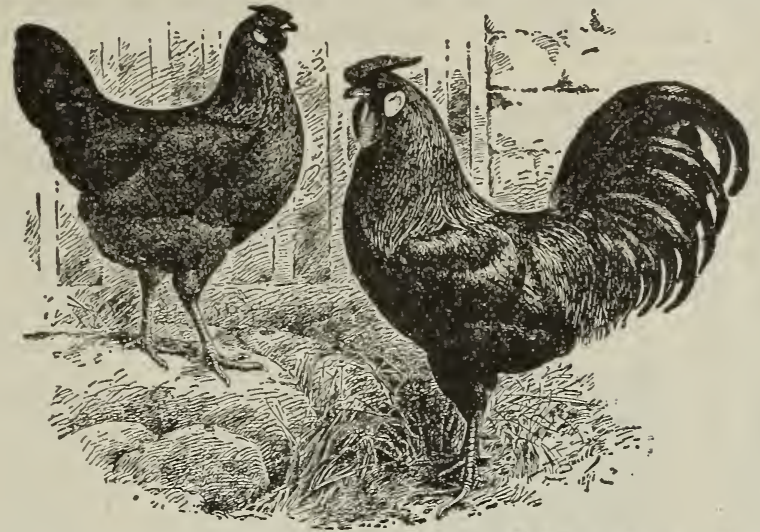

Peas place us in a position to furnish at all times, not only the best stock but also gives the purchaser an opportunity of choosing from many diffeient samples and grades. Samples and prices on quantity submitted on application.

100 Ibs.

Less than 100 lbs.

per 100 lbs.......\$2.00

\section{CRUSHED OYSTER SHELLS}

Crushed oyster shells, to a large extent, will supply the necessary material for grinding their food and at the same time furnish lime for the egg shells. Chemical analysis and experiments, together with the reports from many practical poultry men, show conclusively that the ordinary grain and the green food supplied to laying hens do not contain enough lime for the formation of the egg shells. It will require several times as much lime as is ordinarily fed, if good strong egg times as much lime as is ordinarily fed, if good strong egg shells are to be produced. Crushed oyster shells will supply ing to them to eat the amount needed rather than mixing the ing to them to eat the amount needed rather than mixing the
shells with food. The judgment of the fowls can be relied upon in this respect.

PRICES.

100 Lbs.......... 200 Lbs $65 \quad 5$ Lbs

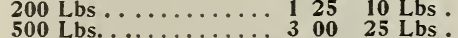

1000 Lbs ........... 5 50 50 Lbs $\ldots$ $\begin{array}{ll}\$ 0 & 10 \\ & 15\end{array}$

PEARL SHELL GRIT.

Pearl grit is a crushed shell obtained in connection with the manufacture of pearl buttons. It contains the same amount of lime, but less salt than Oyster Shell and acts as a grit in grinding the food of fowls, birds, pigeons, etc., making by far the most serviceable and economical grit upon the market. We can furnisi this grit in any quantity desired. Many leading poultry men now use Pearl grit exclusively PRICES.

100 Lbs $\ldots \ldots \ldots \ldots \ldots \$ 0 \quad 60 \quad 5$ Lbs $\ldots \ldots \ldots \ldots \ldots \ldots+10$

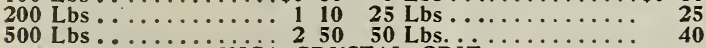
Mi $\dot{C} \dot{A}$ CRYSTAL GRIT.

Examinations of 100 gizzards taken from chickens supposed to have died from Cholera, had no grit of any kind to digest their food, and in each case Diarrhea existed 3 or 4 days before death and food had passed through gizzard just as eaten, before death and food had passed through gizzard just as eaten, proving that indigestion alone was responsible. Analysis, furthermore, proves that Mica Crystal grit is the only rock known showing the combination of Mica, Quart

We carry in stock three sizes. Large for old poultry. geese, ducks and turkeys. Medium for pigeons, and small size for young chickens. PRICES,

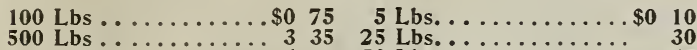

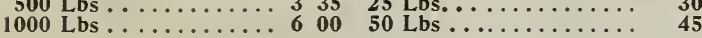

\section{INSECTICIDES}

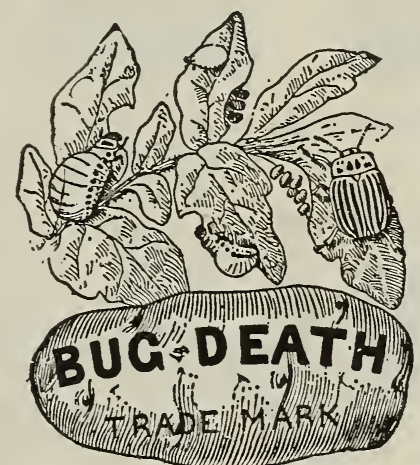

Insecticides cannot bo sent by mail. The prices quoted are net. Purchaser: must pay all express or freight charges. On many of the items prices change with the market, and special quotations will be made upon application. For prices on larger quantit es than quoted write Any information desired in relation to insecticides or fungicides will be given as far as data at hand will permit. Death. This preparation we highly recommend. It is sure death to the potato bug and all other regetable pests, and besides it acts as a fert lizer. We have many testimonials at hand from large vegetable growers, and we feel much confidence in offering it with our endorsement to any of our customers who want a quick-acting non-poi-onous bug killer. It can be used on all vegetable and fruit crops with excellent results. $1=1 \mathrm{lb}$. pkg., $15 \mathrm{c} ; \mathbf{3}=\mathbf{l b}$. pkg., $\mathbf{5 c} ; \mathbf{5}=\mathbf{l b}$. pkg., c $12 \frac{2}{2}=$ b. pkg., $\$ 1.00 ; 100=\mathrm{lb}$. keg, 7.50.

Slug Shot. This well known preparation has been in use for a quarter of a century or more and its popularity does not diminish. It is a standard insecticide everywhere. It can be used on all sorts of vegetation, in the flower garden, on frici: bushes, trees or anvwhere where the insict pest appears. $\mathbf{5}=15$. pkg., 30c; 10 lbs., 50c; 100 lbs., $\$ 4.50$.

Tobacco Dust. If dusted on while the foliage is moist it destroys rose lice, cabbage and turnip fleas, etc. Spread upon the ground it keeps off all earth insects, and also acts as an excellent fertilizer. $1=1 \mathrm{~b}$, box, $10 \mathrm{c} ; 5=1 \mathrm{~b}$. pkg., $30 \mathrm{c} ; 10=1 \mathrm{~b}$. pkg., 50 c; 100 Ibs., $\$ 2.50$.

Tobacco Stems. For fumigating plants infested with greenfly. Bale of about 100 lbs., $\$ 1.50$; bale of about $200 \mathrm{lbs}$. $\$ 2.75$; bale of about 400 Ibs., $\$ 5.00$.

Except where otherwise noted the Prices are all Net, delivered at the Express Office or Freight Depot at Chicago; Purchasers in all cases pay freight or express charges. $:: \quad::$ $::$

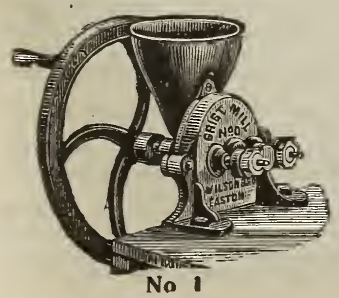

No 1
WILSON'S MILLS.

For poultry raisers the Wilson Mills are almost indispensable. They can be used for grinding oyster shells, bones, stones, old crockery, etc. The Grist Mill No. 0 for grinding into meal all sorts of corn, wheat and other grain. The Bone Mill No. 1 for grinding oyster shells or any other hard substance.

Prices-Grist Mill, $\$ 5.00$; Bone Mill, $\$ 5.50$

Stand, $\$ 2.00$ extra.

WRITE FOR OTHER INFORMATION,

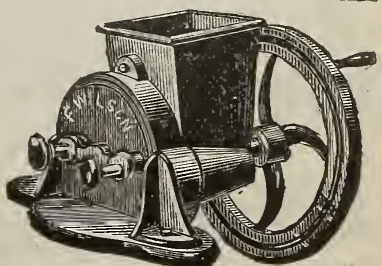

No. 0. 


\section{FERTILIZERS.}

It is unnecessary to tell our customers that Chicago is recognized as headquarters for commercial fertilizer. Here is to be had material for the manufacturing of fertilizer in large quantities and of highest grade. We have made special arrangements with the factory by which we are able to offer this article at the lowest wholesale price, and solicit correspondence from parties wishing large quantities. We can save you money if you buy by the sack, ton or carload. Fertilizer Prices vary.

PURCHASER PAYS THE FREIGHT.

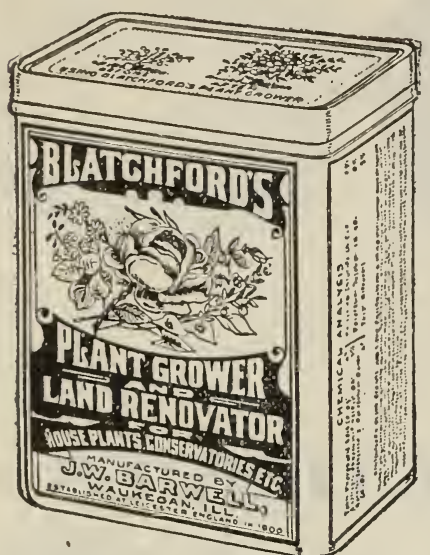

\section{BLATCHFORD'S}

\section{Plant Grower} AND

\section{Land Renovator.}

This splendid Fertilizer is composed of pure nitrate of soda, sulphate of potash, peruvian guano, sulphate of ammonia, bone meal and gypsum. It is excellent for lawns, indoor plants, vegetable crops and for all purposes for which a fertilizer is needed.

100 lb. bag. . ..............\$3.00 20 lb. bag.

10 lb. bag.

Special quotations on large lots.

HIGH GRADE ACID PHOSPHATE.

\section{Guaranteed Analysis.}

Available Phos. Acid ..14 to 16 per cent

This brand was put on the market to supply the demand for a cheap Fertilizer. running high in Available Phosphoric Acid only.

We know from past experience, that crops need Nitrogen and Potash, as well as Phosphoric Acid and farmers who taining nothing but Phosphoric Acid, invariably find that high grade goods are more economical, because better results are obtained. 100 lbs., \$1.50; 200 lbs., $\$ 2.25$; ton, $\$ 20.00$.

\section{BIG POTASH BRAND.}

Guaranteed Analysis.

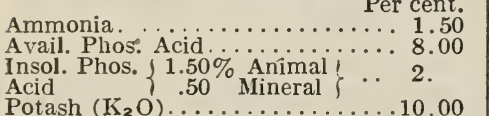

Potash $\left(\mathrm{K}_{2} \mathrm{O}\right) \ldots \ldots \ldots \ldots \ldots \ldots \ldots . \ldots \ldots$

This brand as you will note, runs high in Potash and Phosphoric Acid, also which make it an excellent all-around fertilizer, especially adaptable for crops that are heavy feeders of Potash.

Results secured from the use of this

brand make it very popular. 100 lbs.,

GENERAL CROP BRAND. Guaranteed Analysis.

Ammonia

Avail. Phos. Aci

Insol. Phos. Acid $\left\{\begin{array}{l}1.50 \% \text { Animal } \\ .50\end{array}\right.$

Potash $\left(\mathrm{K}_{\mathbf{2}} \mathrm{O}\right)$

for all crops where ammonia is not need-
Vegetable and Lawn. Guaranteed analJsis: Ammonia, 4 to 5 per cent; available phosphoric acid, 7 to 9 per cent total phosphoric acid, 8 to 11 per cent; actual potash, 7 to 9 per cent. This is positively the best article on the market for use as a complete manure for all purposes. It is the best lawn fertilizer ever prepared. Note the large amount of actual potash in this brand. $10 \mathrm{lb}$. pkg. $\$ 2.00$; 200 lbs., $\$ 3.50$; ton, $\$ 33.00$.

Farmers' Favorite Brand. Guaranteed analysis: Ammonia, $3 \frac{1}{2}$ to $4 \frac{1}{2}$ per cent; available phosphoric acid, 8 to 9 per cent; total phosphoric acid, 13 to 14 per cent; actual potash, 4 to 5 per cent. 200 pounds of this will go as far as 600 pounds of almost any other brand on the market. It is available for spring the market. It is available for spring crops brand on the market for fruit trees, vines and small fruits. $10 \mathrm{lb}$. pkg., 50c.; 25 lbs., $\$ 1.00$; bag of 100 ibs., $\$ 1.90 ; 200$ lbs., $\$ 3.00$; ton, $\$ 29.00$.

Sure Winner Brand. Guaranteed analJsis: Ammonia, $1 \frac{1}{2}$ to $2 \frac{1}{2}$ per cent available phosphoric acid, 7 to 9 per cent total phosphoric acid, 12 to 14 per cent actual potash, 3 to 4 per cent. For land and crops requiring minerals (phosphoric acid and potash) and very little ammonia this brand fills the bill. $10 \mathrm{lb}$. pkg., 50c. 25 lbs.; $\$ 1.00$; bag of 100 lbs., $\$ 1.50$ 200 lbs., $\$ 2.75$; ton, $\$ 26.00$.

Chicago Brand Guaranteed analysis: Ammonia, $2 \frac{1}{2}$ to 3 per cent: available Ammonia, $2 \frac{1}{2}$ to 3 per cent; available phosphoric acid, 7 to 9 per cent; tota phosphoric acid, 11 to 14 per cent; actual gotash, 1 to 2 per cent. This brand gives you a combination of nitrogen and
phosphoric acid, with very little potash, and where potash is not needed, gives very good results $10 \mathrm{lb}$. pkg., $40 \mathrm{c}$.; 25 $\$ 2.50$; ton, $\$ 23.00$.

Nitrate of Soda. Should be sown sow it evenly. 2 or 3 pounds on a square

ed in large quantities. You will note it contains a large amount of Available Phos. Acid and is very rich in Potash consequently is a good all-around fertilizer. 100 lbs., $\$ 1.50 ; 200$ lbs., $\$ 2.75$; ton, $\$ 25.00$.

TWO AND TWENTY BONE. Guaranteed Analysis. Per cent Ammonia. Total Phos. Acid. .. 18 This also is soft steamed bone, running a little lower in both ammonia and phosphoric acid than our Pure Ground Bone, yet is better than most brands of bone now on the market. 100 lbs., $\$ 1.50$ 200 lbs., $\$ 2.75$; ton, $\$ 26.00$.

PURE BONE AND POTASH. Ammonia.uranteed Analysis. Per cent Total Phos. Acid.............. 20.15 Potash $\left(\mathrm{K}_{2} \mathrm{O}\right) \ldots \ldots \ldots \ldots \ldots \ldots 6.00$ The above brand is made of a Soft Steamed Bone with Potash in form of Sulphate added, and is especiall

For the fruit trees and small fruit. been used in the fruit belt of Michigan and has given the very best of satisfac-
tion. 100 lbs., $\$ 2.00 ; 200$ lbs., $\$ 3.75$; ton, $\$ 33.00$.

PHOSPHATE AND POTASH BRAND Guaranteed Analysis.

Per cent

Avail. Phos. Acid.

Potash $\left(\mathrm{K}_{2} \mathrm{O}\right) \ldots 0$ lbs., $\$ 1.00 ; 200$ lbs., $\$ 1.85 ;$ ton, $\$ 18.00$.

\section{TEN-FIVE BRAND.}

Avail. Phos. Acid ................10 Potash $\left(\mathrm{K}_{2} \mathrm{O}\right)$

The above brands are "specials" and rod will be beneficial. 25 lbs., $\$ 1.50$; 50 lbs., \$2.00; 100 lbs., \$3.25; 200 lbs., $\$ 6.50 ; 500$ lbs., $\$ 15.00$.

Pure Ground Bone, Steamed. Guaranteed analysis: Ammonia, 3 to 4 per cent; bone phosphate, 50 to 60 per cent; equal to phosphoric acid, 24 to 26 per cent. In steamed bone, pure and in the best possible condition. Users of bone alone can find no better article. It will analyze nearer the highest per cent given in our nearer the highest per cent given in our guarantee than it will the lowest. It gives great big results on fall crops. 10 $\$ 1.60$; 200 Ibs., $\$ 2.85$; ton, $\$ 27.00$.

Ground Raw Bone. Guaranteed analysis: Ammonia, 4 to 5 per cent; bone phosphate, 45 to 55 per cent; equal to phosphoric acid, 21 to 25 per cent. This is a pure ground raw bone-no rock is put in to cheapen it. These goods also will analyze nearer the highest limit of our guarantee. 10 lbs., 50c.; 25 lbs., $\$ 1.00$; bag of 100 lbs., $\$ 1.90 ; 200$ lbs., $\$ 3.00$; ton, $\$ 33.00$.

Florict's Plant Food. This article has been made at the suggestion of florists, who desired to obtain in an inexpensive,
effective and odorless preparation, that would act quickly on plants and furnish food for flower and leaf. An application of this plant food will be observed in the vigorous growth of the flowers and lbs., $\$ 100 ; 25$ lbs., $\$ 1.75 ; 50$ lbs., $\$ 2.00$; 100 lbs., \$4.00.

Blood and Bone. Manufactured of pure blood and bone. When this fertilizer is used in rows or in hills for such crops as celery, cabbage or early corn, from 100 to 200 pounds per acre will b enough. 200 lbs., $\$ 3.00$; ton, $\$ 27.00$.

Bowker's Plant Food. An excellent fertilizer for house plants. Clean to handle, without odor, produces rich green growth and profusion of flowers. Directions for use accompany each pack age. Small pkg., 15c.; by mail, 20c. large pkg,. $25 c_{\text {.; }}$ by mail, $40 \mathrm{c}$.

give good results where Ammonia is not required. 100 lbs., $\$ 1.50 ; 200$ lbs., $\$ 2.50$; ton, $\$ 22.00$.

GENERAL DIRECTIONS FOR USING.

The best way to apply fertilizers to field crops is to use a fertilizer drill. Otherwise, sow broadcast after plowing or spading, then rake or harrow into the soil before planting. The main point is to work the fertilizer into the soil as thoroughly as possible. For all field crops according to the soil.

For market gardening, potatoes, or any crops that are hearty feeders and need rich manuring, use from 400 to 600 pounds per acre. Fertilizer can be used in the hill on hill crops instead of broadcasting, using from a teaspoonful to a small handful, according to the the plant, but being careful to work the ertilizer into the soil.

Fertilizers can always be used to good advantage by working them into the soil along the rows after the plant is up, care being taken not to let it come in plant. For plants that are transplanted, work the fertilizer into the soil thoroughly before transplanting, using from a teaspoonful to a small handful, according to the size and the nature of the plant.

For fruit trees make two applications a year, one in the spring and one in July, using from two to five pounds per tree, according to the size of same, broadcasting, then raking into the soil.

Always remember that it is the root of a plant that takes up the plant food, and that fertilizers should be applied in such a manner that the roots can best take it up. 


\section{Miscellaneous Tools and Requisites.}

\section{Purchaser Pays the Postage, Expressage or Freight, Except Where Noted Otherwise.}

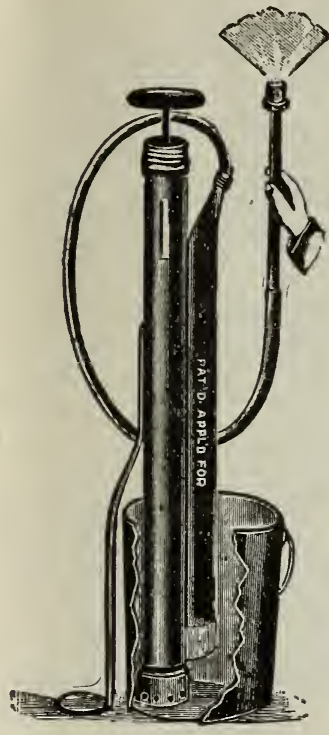

No. 28.

THE “LIGHTNING" WHITE WASH SPRAYER AND FORCE PUMP NO. 28.

Will Fit Any Pail or Bucket.

This is the only spray pump that will spray white wash without clogging. It is constructed of heavy galvanized iron without clogging. It is constructed of heavy galvanized iron with brass top and bottom. It is made with large air chamber and has ball valves. Pressure being held in air chamber and hose, so that nozzle throws continuous spray, and is not affected by upward strokes. Pump is provided with 3-foot hose, 1-foot extension pipe with brass end nozzles. Is used for bucket spray and white washing. Price, \$1.50.

THE "LIGHTNING SPRAYER" No. 21 .

Operated by Compressed Air.

Accompanying cut represents our No. 21 compressed air sprayer. No labor required to operate it. Simply fill tank twothirds full of liquid, pump in a few strokes of air with pump attached to tank and all labor is done. Machine is furnished with 3 feet of hose and automatic brass nozzle, which is held in one hand and operated by pressing the thumb a trifle, letting out an instantaneous spray; and by re-

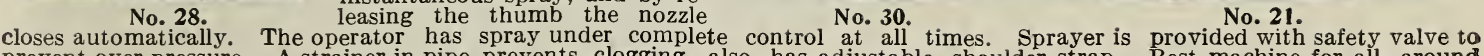
prevent over pressure. A strainer in pipe prevents clogging, also has adjustable shoulder strap. Best machine for all around spraying, throwing a continuous stream or a mist like spray. Fine for use on potatoes. Prices, No. 30, 2 Gal., $\$ 2.00 ;$ No. 21,4 Gal., $\$ 3.50$.

OUR WOOD BEAM WING SHOVEL PLOW.

Who will do without this valuable tool when it is to be had at such a low price. This favorite shovel plow is one of the most useful tools any farmer or gardener can have. There is no excuse for slaving with a hoe, when ten times the amount of work can be done so easily with a shovel plow. There never yet was such a chance to get a good tool so cheap. Send an order for one of these shovel plows with your seed order, and save freight. The workmanship on this shovel plow is right up to the standard; nothing is cheap about it

right up to the standard; nothing is cheap about itbut the price. It will save ten times its cost in labor before the first of June.
The hinge wings are adjustable; can be worked at any angle. It will hill-up anything-cabbages, corn, potatoes and everything that needs hilling. One horse and a boy are all you need to work it.

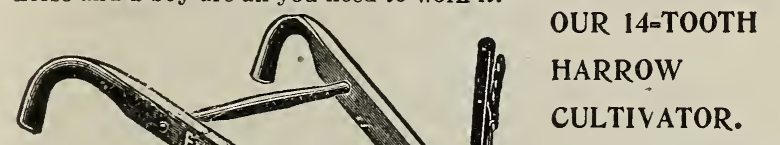

Price,

Complete,

with

Expand-

ing

Lever

and

Wheel, $\$ 4.25$

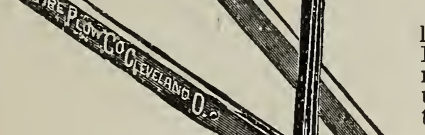

Notice this complete steel frame cultivator harrow It has an expanding lever and a gauging wheel. The fourteen teeth are reversible and adjustable. Every part is put together in first-class shape. No harrow cultivator on the market to-day is put up better. Hundreds of these harrow cultivators are in use amorig the Chicago market gardeners, and not a one of them would be willing to do without this tool, if the cost was double what it is. It is the best tool on
earth to do away with the weeds when they are small: it roots up earth to do away with the weeds when they are small; it roots up It fills a want that no other machine can. We put our price right down to within a shade of actual cost. You cannot beat our price, and you ought to have the tool.

No farmer or gardener can afford to do without a wheelbarrow. The prices we name on the standard make, shown here, are so moderate that it is within reach of all. They are made in two sizes; are of the best material and will give satisfaction to al.

Size 1. As shown in cut. Price, $\$ 3.00$.
Size 2. Larger than No. 1. Price, $\$ 3.50$.

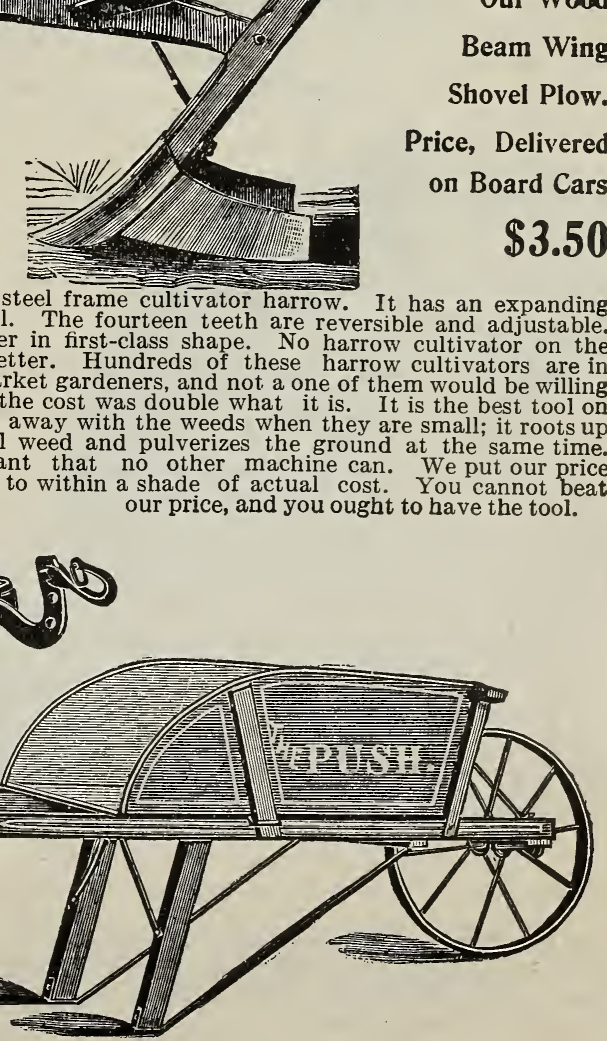




\section{Planet Jr. Farm and Garden Tools}

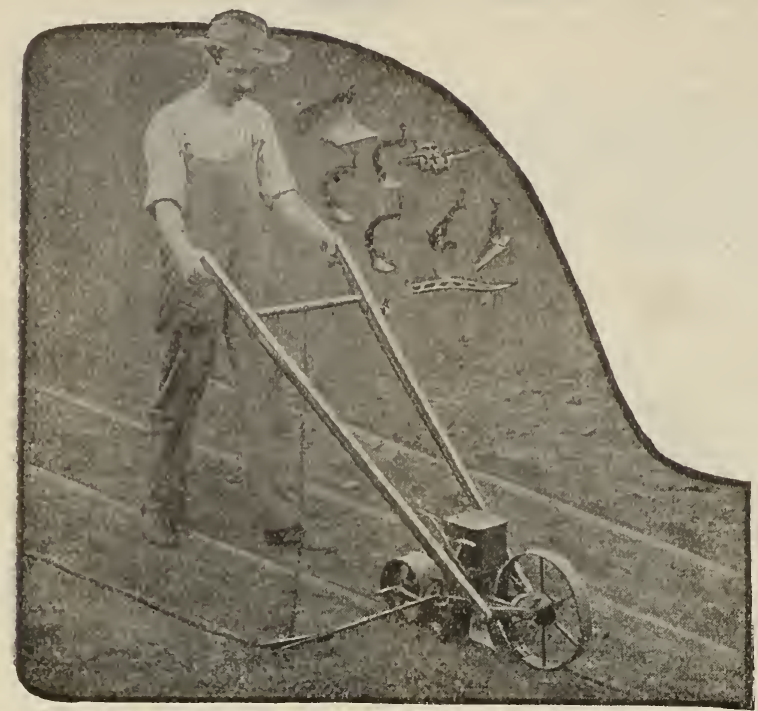

\section{Planet Jr. No. 4 Combined Seed Drill, Single Wheel Hoe, Cultivator and Plow.}

The No. 4 Planet Jr. Combined Drill and Hoe is capable of a large varicty of uses, as it will make the furrow, drop the seed, mark rows, roll down, and is extremely valuable as a land cultivator for all times of the year on any crop. Every reader should secure the Planet Jr.illustrated catalog for 1910 , showing the No.4 and many other valuable hand and horse labor-saving farm implements This book will be of much interest to every man or woman who tills the soil for pleasure or for profit. It may be had by sending a postal card.

\section{Price, complete, $\$ 11.00$}

Price as a seeder only $\$ 9.00$

Planet Jr. No. 25 Combined Hill and Drill Seeder, Double Wheel Hoe, Cultivator and Plow.

This new combined machine is intended for gardeners who have a large enough acreage in crops for a Double Wheel Hoe to be used to good advantage and prefer not to buy separate machines.

As a drill it is almost identical with the Planet Jr. No.4 Drill, and is thoroughly substantial and accurate in sowing all kinds of garden seeds in hills or drills.

As a Wheel Hoe it is identical with the Planet Jr. No. 12 Double Wheel Hoe, the very best machine on the market. The change from Drill to Wheel Hoe takes but a moment, and the whole combination is one we can heartily recommend and guarantee satisfactorily.

Price, $\$ 13.50$

The Planet Jr. Seed Drills are gaining in popularity. Market gardeners are beginning to realize that the extra cost of these Drills is more than made up for by the time gained by using them.

\author{
Planet Jr. No. 3 Hill and Drill Seeder.
}

This seeder is the latest and most perfect development of the hand seed drill. It sows evenly in drills, and also drops in hills at 4, 6, 8, 12 or 24 inche's apart. It is thrown out of gear instantly by moving a convenient lever, or the flow of seed is stopped by pushing down the feed rod. No time is lost, no seed is wasted. It is quickly set to sow the different kinds of seeds in the exact thickness required.

The accurate hill-dropping drill, which gives a regular stand of plants with the least seed, saves its cost over and over again in seed alone. We guarantee this chill to be accurate and give satisfaction in every respect.

Price, $\$ 10.50$

Planet Jr. No. 6 Combined Seed Drill, Single Wheel Hoe, Cultivator and Plow.

This is the most popular combined tool made. It combines in a single implement a first-class hilldropping seeder, a Single Wheel Hoe or Weeder, a cultivator and a plow. The hopper holds two quarts of seed, which can be sown in continuous rows, or dropped in hills at $4,6,8,12$ or 24 inches apart.

The drill is detached and the tool frame substituted by removing but one bolt. It then becomes a single wheel hoe. It is useful almost every day of the season, at every stage of the garden work. With this one implement the small farmer can do practically all the work in his small crops.

Price, complete, $\$ 13.50$

Price as a seeder only $\$ 11.00$

\section{No. 5 Planet Jr. Hill and Drill Seeder.}

$16 \frac{1}{2}$ inch steel wheel. Sheet steel hopper holding 5 quarts. Weight, packed, $51 \mathrm{lbs}$.

Special size for market gardeners and farmers, for sugar beet and onton set growers, etc. It is the great hand-power planter for both hills and drills, where the amount of sowing to be done is large. It runs light, and plants equally woll with a full hopper or with an ounce of seed, and up hill or down.

Price, $\$ 13.00$

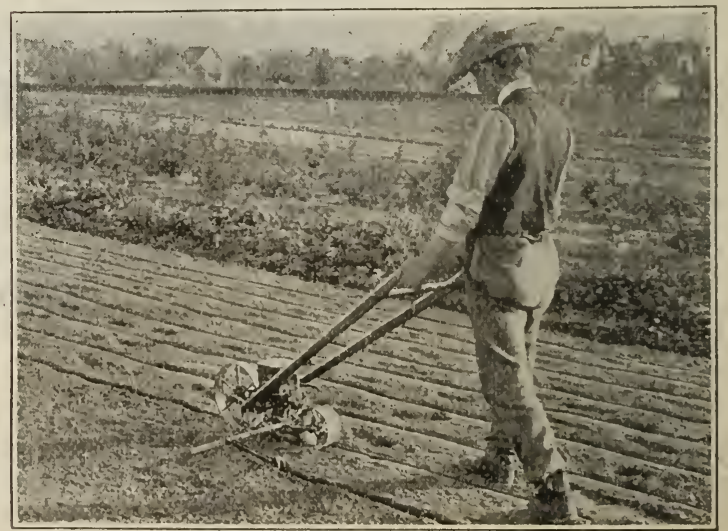




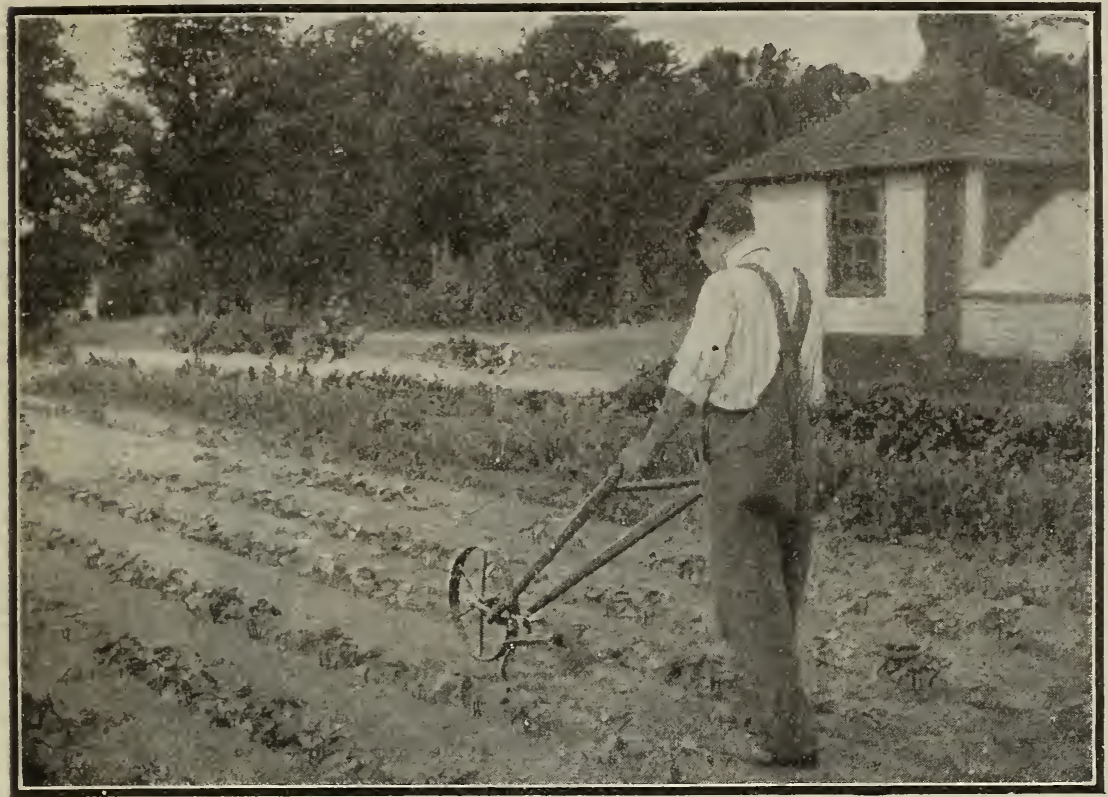

Planet Jr. No. 17 Single Wheel Hoe, Cultivator and Plow.

For easy gardening, and at the same time clean and perfect gardening, the kind that will make your garden the talk of the neighborliood and cause your face to glow with honest pride, nothing is quite the equal of this No. 17 Single Whieel Hoe. It is suited to all kinds of garden cultivation and all garden crops. You call do more and better hoeing with it in one day than you can do in three days with a hand hoe. The No. 17 has a pair of 6-inch hoes, a plow and a set of cultivator teeth, an outfit sufficient for most garden work.

Other attachments can be added at any time.

Price $\$ \mathbf{5 . 2 5}$

PLANET JR. No. 18 SINGLE WHEEL HOE.

\section{Planet Jr. No. 13 Double Wheel Hoe.}

This tool is the No. 12, but with the hoes only-the most useful of the attachments.

\section{Price $\$ 5.00$}

The other attachments can be added at any time and will be found to fit.

\section{Planet Jr. No. 12 Double Wheel Hoe, Cultivator and Plow.}

Two acres a day can easily be worked with this implement and when it is done it will be a better job than three men could have done in the same time with hand hoes. The No. 12 runs either astride or between the rows; kills all the weeds and leaves the earth in fine shape. Then, too, it's so easy to work. Twelveyear-old girls work gardens with them with ease and success.

The No. $\$ 2$ has a pair of 6-inch hoes, a pair of plows for opening or covering, and a set of 4 all steel cultivator teeth. The tools shown are what gardeners use most and others can be added as wanted.

Price $\$ 7.35$

Planet Jr. No. 8 Horse Hoe and Cultivator.

Price $\$ 9.00$

Planet Jr. Twelve=Tooth Harrow, Cultivator and Pulverizer.

Complete Price $\$ 9.00$

Less Pulverizer, $\$ 7.40$

Less Wheel and Pulverizer, $\$ 6.20$
No. $17 \frac{1}{2}$ Single Wheel Hoe.

Is the same as the No. 17 , but has a leaf lifter in place of the plow.

Price $\$ 4.75$

No. 18 Single Wheel Hoe.

Is the No. 17 with Hoes only.

Price $\$ 3.75$

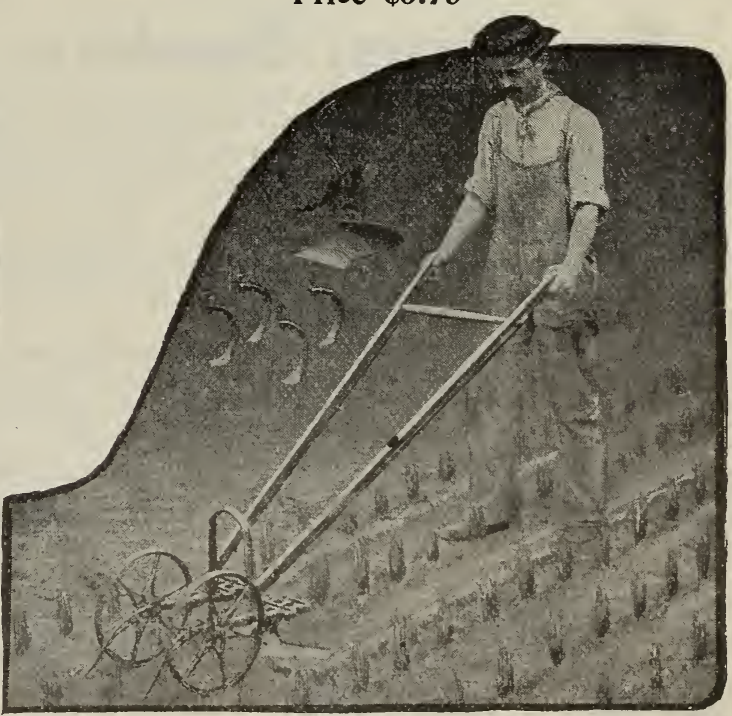

PLANET JR. NO, 12 DOUBLE WHEEL HOE.

The "Planet Jr." Goods are standard articles. In workmanship they stand at the top.

"Planet Jr." Complete Catalogue sent free to all who apply for it. 


\section{TWO POPULAR SEED DRILLS}

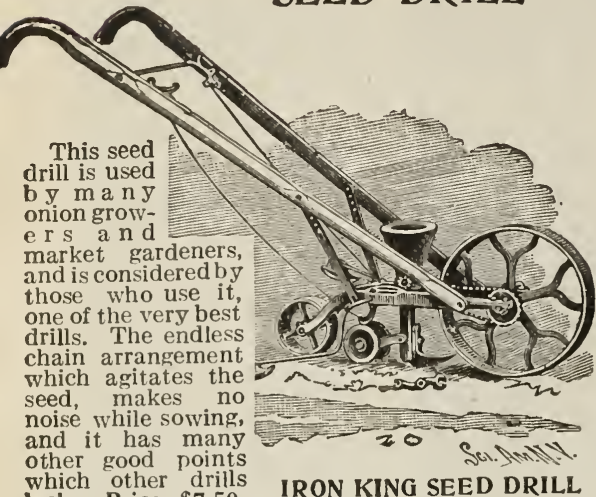

\section{IRON KING SEED DRILL

\begin{abstract}
NEW MODEL
\end{abstract} SEED DRILL}

The diamond shaped adjustable hole regulates the discharge, and can be made

casion requires, The seed cut-of claps up underneath the hole; it does not slide under the same, as in other similar drills; on this account it does not clog nor cut the seed. Price, $\$ 7.50$.

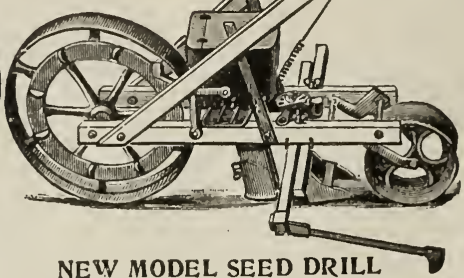

THE McGEE CULTIVATOR,

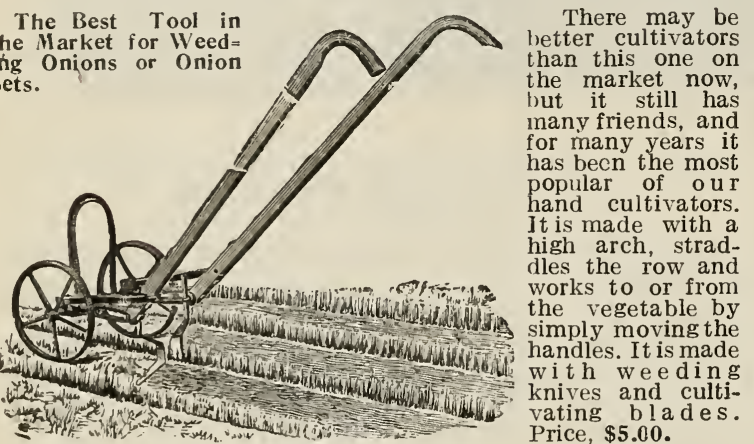

HAND

CORN PLANTERS

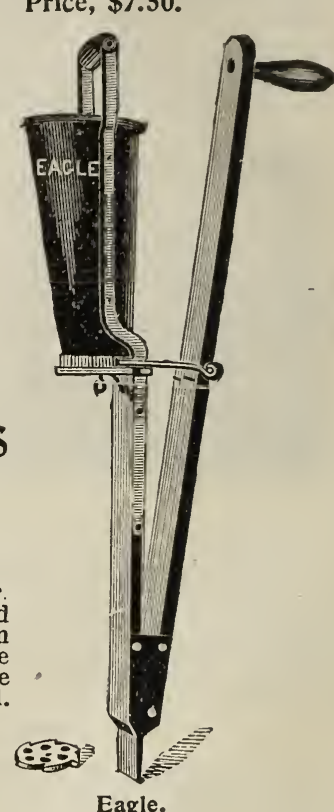

McGee Cultivat or

\section{THE EAGLE.}

This is a rotary planter having three different sized plates, which can be put in or taken out as needed in the prates, which can most popular planter of all. Each, \$1.25,

\section{Broadcast Seeders}

THE CAHOON. This well known broadcast seed sower is contidered anong the best. It is easily worked and sows timothy, clover, lax, wheat, oats, rye, barley, all kinds of grass, and may be used by bie gardener for spinach seed or any other kind which he may wish lo sow broadcast. Each, $\$ 3.25$.

THE GRANGER. This sower is similar to the Cahoon in size ind general appearance. It works easily, is of strong make and will sow evenly and satisfactorily grain, grass, clover, and all farm seeds which are sown broadcast. Each, $\$ 2.00$.

THE CYCLONE. A seeder which is becoming very popular. It differs from the above mentioned kinds in construction, but does about the same work. It is a cheaper machine and a good one. Each \$1.50.

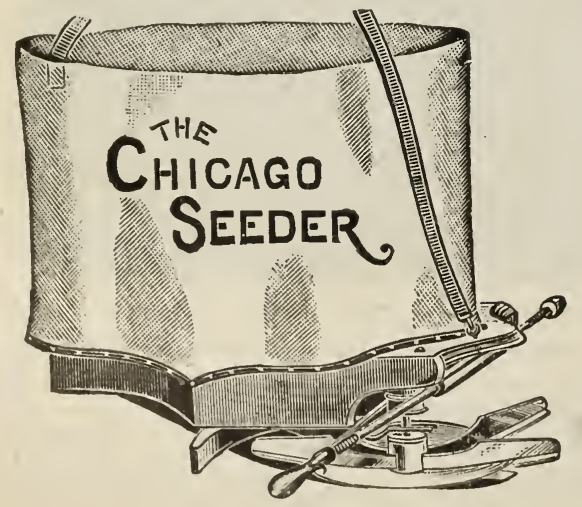

THE CHICAGO
This is the best of
the fiddle=bow seeders.
Thousands of the $\mathrm{m}$
are in use, and they
give the very best of
satisfaction.
Each, $\$ 1.00$.

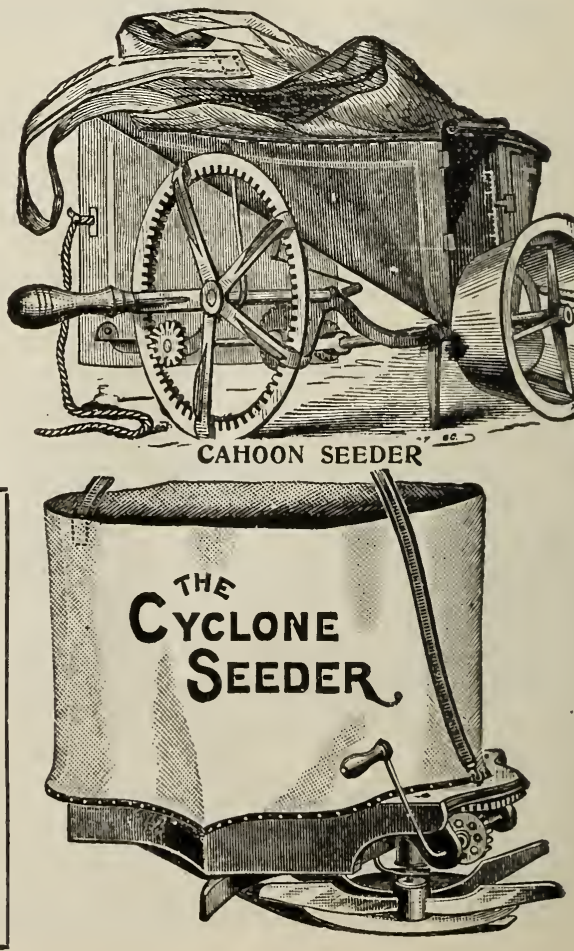




\section{MATHEWS' \\ UNIVERSAL GARDEN TOOLS.}

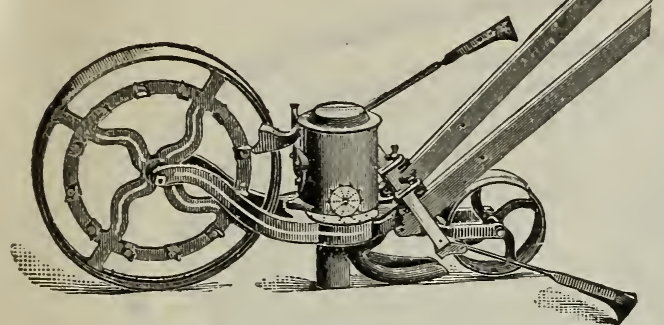

MATHEIVS' UNIVERSAL SEED DRILL.

MATHEWS' NEW UNIVERSAL DRILL.

It works on the agitator principle, which is certain in its action, and much preferable to any other method in dropping the seed, and besides there is nothing liable to get out of order or bind in the operation. It opens the furrow, drops and covers the seed, rolls down the earth over it and marks the next row, all by simply pushing the drill forward. It sows with evenness and rapidity peas, beans, broom corn onion, beet, carrot, parsnip, sage, etc. It is provided with an indicator, having the names of different seeds thereon. Before planting turn the indicator around until the name of the seed to be sown

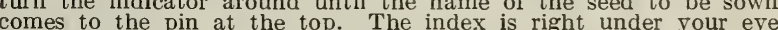
comes to the pin at the top. The

while the hopper is easily watched. attachment shown on the handle. Beware of cheap imitations of this drill. None genuine but those having the patent indicator. Price, boxed, $\$ 6.50$.

MATHEWS' NEW UNIVERSAL CONSTELLATION DRILL.

The Latest Improved and Most Complete Combination upon the Market. Six Implements in One. Price,

Complete, $\$ 8.50$.

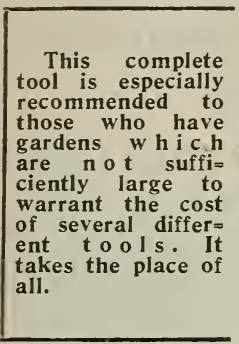

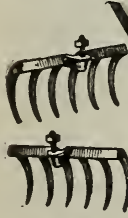

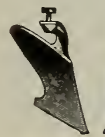

$i^{\pi}{ }^{\pi}$
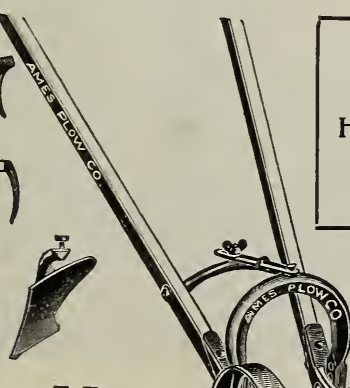

MATHEWS' NE WV

Complete Catalogue of

MATHEWS'

HAND GARDEN TOOLS

FREE

ON APPLICATION.
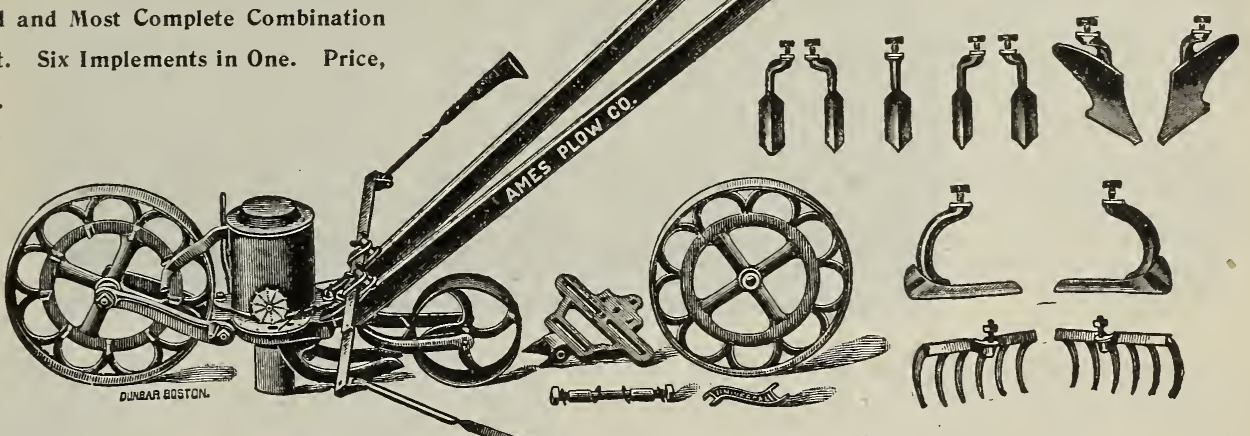

UNIVERSAL CONSTELLATION DRILL.

MATHEWS' HAND CULTIVATOR.

This is one of the best implements in use for weeding between row crops, and for flat cultivation generally, and is an indispensable companion implement to the seed drill. It is thoroughly constructed very durable, and easy to operate It spreads from 6 to 14 inches, and will cut all the ground covered even when spread to its greatest ground corered rately gauged by raising or lowering the wheel rately gauged by raising or lowering the wheel which is quickly done. Prices complete, as in cut.
Cultivator with five teeth, \$5.00. With two weeding blades only, $\$ 4.50$.

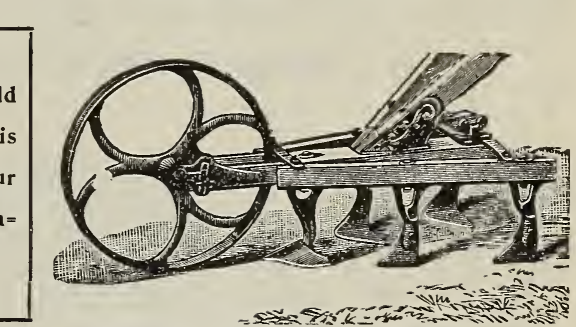

NEIV UNIVERSAL DOUBLE WHEEL HOE.

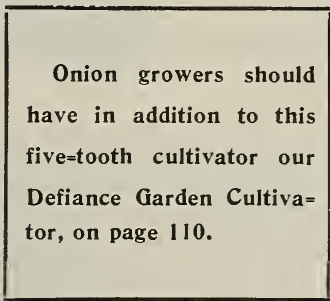

NEW UNIVERSAL DOUBL E WHEEL HOE.

Specially designed for working both sides of the row at one passing. This new hand implement embraces all the good points of older efforts in the same line, and in addition, offers new features which cannot fail of appreciation. The special pocommendation is the adjustable arch, by which not only the depth of work can be gauged, but which, by an ingenious device, enables the teeth to be pitched at any angle desired. The attachments are-one pair hoes, four cultivator teeth, one pair plows, one pair rakes and one pair vine guards. Price, $\$ \mathbf{5 . 5 0} ;$ with one pair hoes only. The same machine as the foregoing, rakes, plows, cultivator teeth and leaf guards omitted. Price, $\$ 3.50$.

\section{NEW UNIVERSAL SINGLE WHEEL HOE.}

This is an improvement over other tools of this type. It can be used either between or astride the rows, although it is really intended for between row cultivation. For straddle cultivation, the wheel can be set to one side, so as to bring the row of young plants under center of frame. The adjustment for graduating the depth of cultivation is unique and readily accomplished. The attachments $a^{r}$ one pair hoes, five cultivator teeth, one pair plows, one pair rakes, and one vine or leaf guard.

Price, boxed, with all attachments. . . . . . . . . \$4.25

If one pair hoe blades, only..............\$2.75

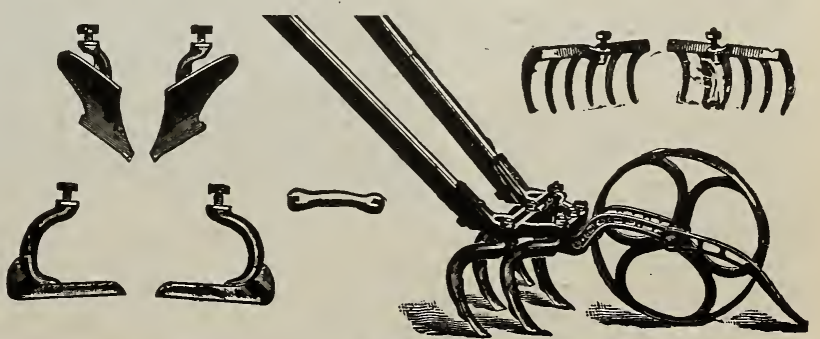

NEW UNIVERSAL SINGLE WHEEL HOE. 


\section{THE}

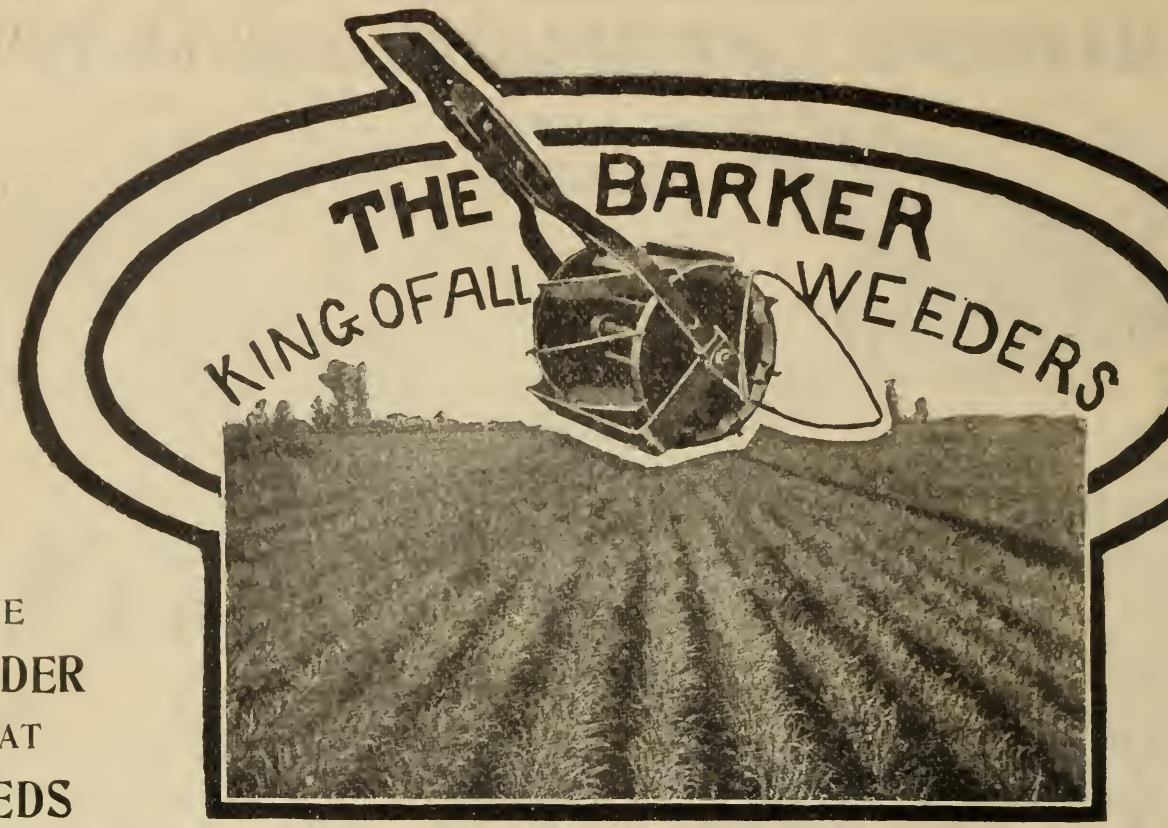

THE

\section{MULCHER}

\section{THAT}

\section{MULCHES}

THE BARKER WEEDER operates on the plan of a lawn mower. It is easy to operate. It forms a dust mulch, cuts the weedis under, the ground as well as the weeds out of the ground. It pulverizes the ground fine which holds the moisture to feed the plant. To appreciate the value of this tool you must take it to the field. You cannot judge it properly by looking at it, take it out into the patch, pick out a piece of vegetation that needs weeding. Notice the work it does. Let your man work it. If you are not satisfied with it after giving it a fair trial, you can return it. Hundreds of the best market gardeners and onjon growers have taken this tool to try and have kept it and bought more. It is a money saver. It costs thousands of dollars annually to weed onions and other market garden crops. The machine that can do the work best in the shortest time saves the most money for the grower. EVERY CENT SAVED IS GAIN. The revolving blades of the Barker do far better work than the stationary bolted knives used on other machines. With the revolving bladesof the Barker the surface of the ground is chopped, the weeds are cut, separated from the soil and thereby destroyed. With the bolted knives used on other weeders, the knife slips under the weeds oftentimes leaving them standing without disturbing the earth that hangs to the roots, and the weeds thus left start right in to grow again. You do not have to draw the Barker Weeder back after each forward motion like you do other hand wheel hoes. It is a steady forward push like running a lawn mower. You can walk fast or slow, as best suits you. With the Barker you do the work better, quicker and save yourself the extra labor of the see-saw motion that is necessary to do effective work with any of the other hand weeders.

\section{NO MARKET GARDENER CAN AFFORD TO DO WITHOUT THIS TOOL.}

\section{The Barker \\ 3 Sizes}

The Barker is make in 3 sizes. Viz: 6 =inch cut, $8 \frac{1}{2}=i n c h$ cut and $11=i n c h$ cut. Each machine is fitted up with leaf guards and tooth attachment. The 81 -inch cut is the standard size for onion sets and ordinary market garden crops. The 6 -inch is for lettuce and crops that are planted in close rows. The 11-inch for crops that are planted from 14 to 18 inches apart in rows.

Either Size Complete

Price \$5.00

\section{As a Double Machine}

THE BAKER can be adjusted to work on both sides of the row. What we call a "Double six" has heen found the best for this purpose. The double six consists of two six inch machines bolted together. Bars for this purpose are furnished without extra charge. The bolting together of the two machines is a very simple process and when clesired they can be unholted easily and used as single machines. Two eight inch machines can be used in inch machines can be used in the same way where the row's
are wide enough apart. For onion sets the double machine will pay for itself in one day's working.
A "DOUBLE SIX" BARKER IN OPERATION. 


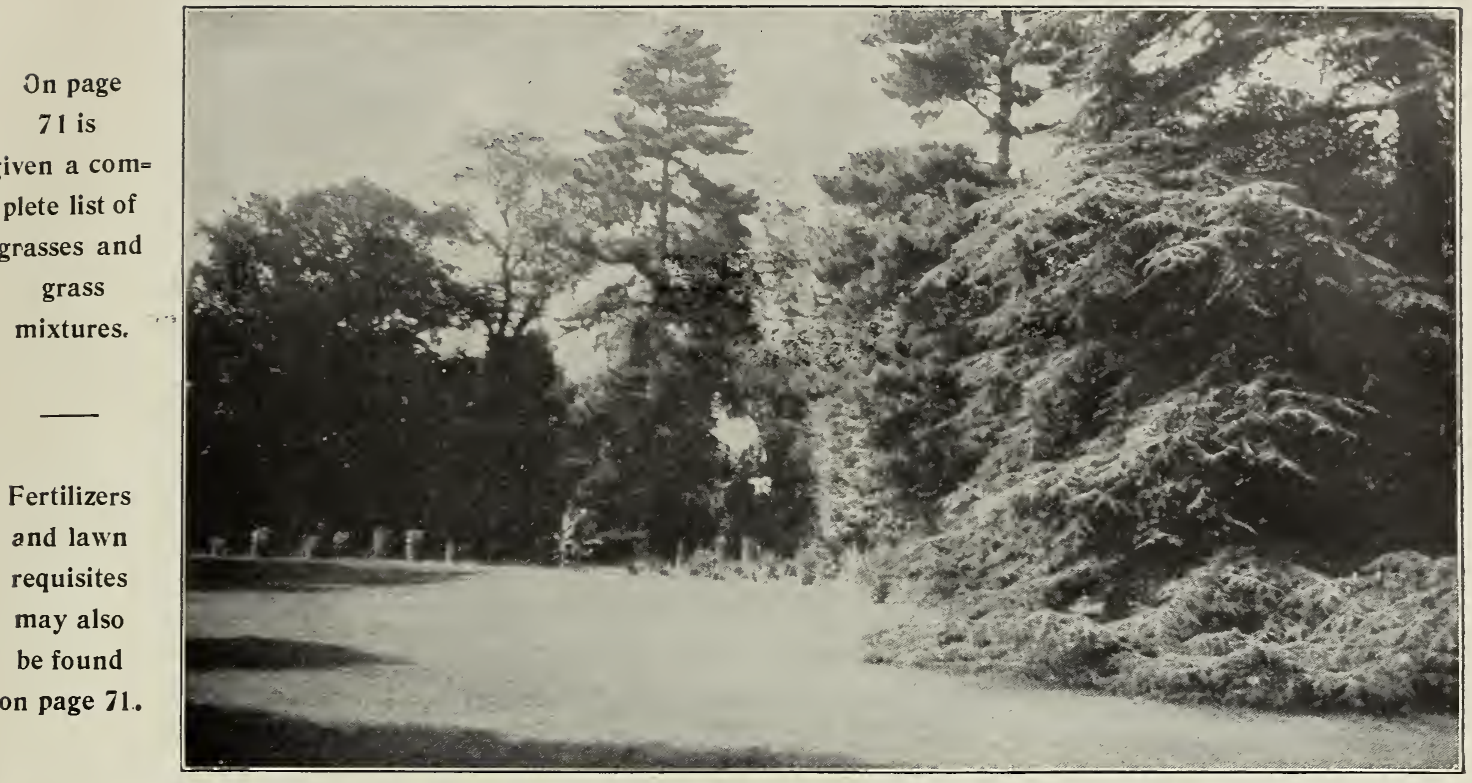

CHICAGO PARKS LAWN GRASS

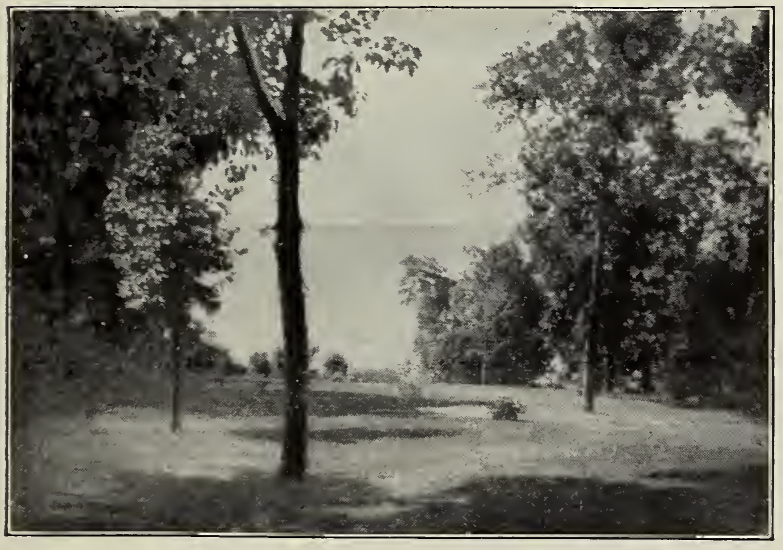

SHADY NOOK LAWN GRASS

Nothing is more charming than a beautiful, smooth, velvety well kept lawn, surrounding a well designed house.

The essentials for a perfect lawn are Good Seed and unceasing care with continued rolling of the turf. We can furnish the seed but not the work.

The first consideration is, of course, the seed which should be a carefully blended mixture of the different grasses which make a close interweaving growth such as Leonard Seed Company use in making their various mixtures.

See page 71 for special mixtures for Golf Links and Tennis Courts, also other special mixtures. Our special blends of grasses for all purposes are pre= pared with care from the best formulas of experienced landscape gardeners and practical lawn makers.

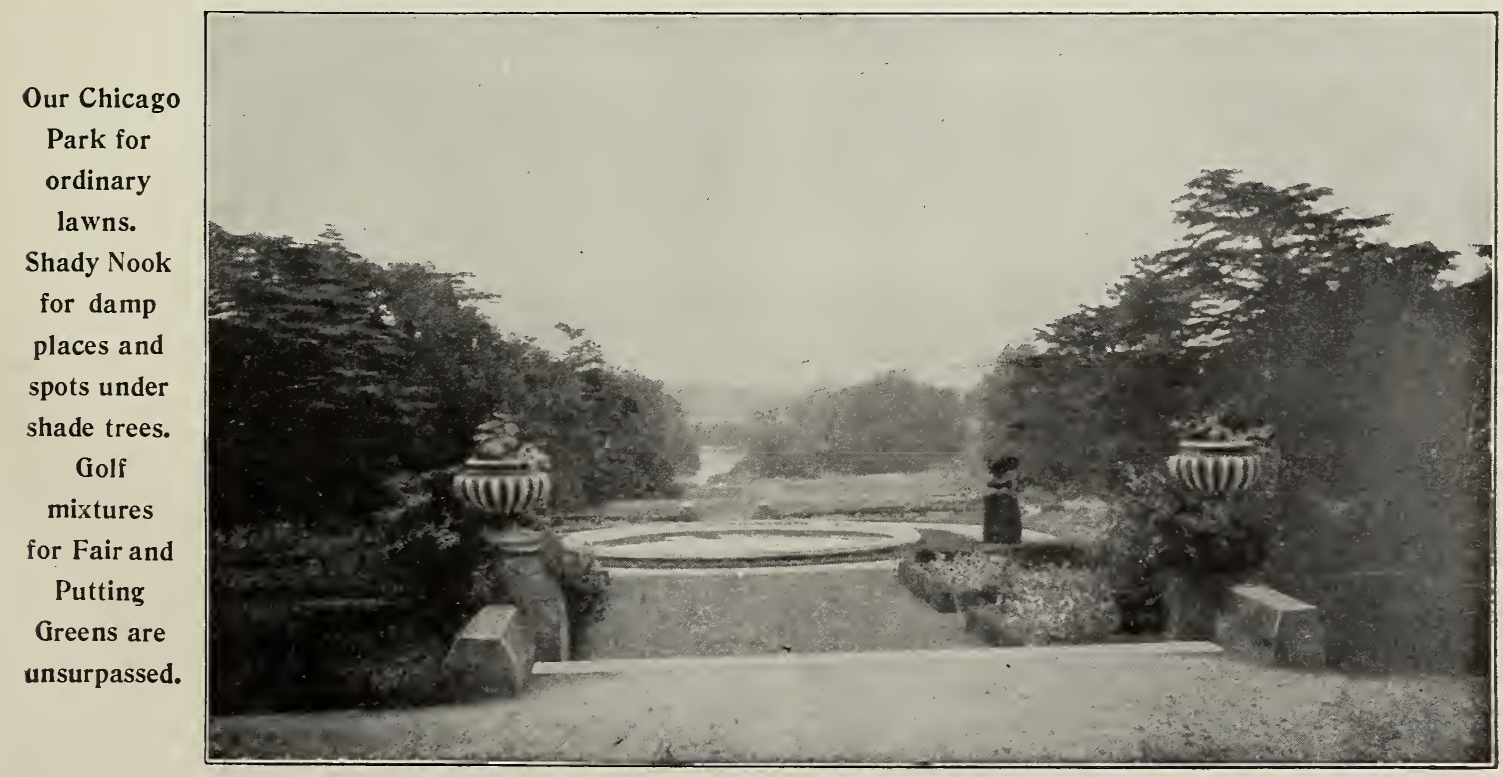




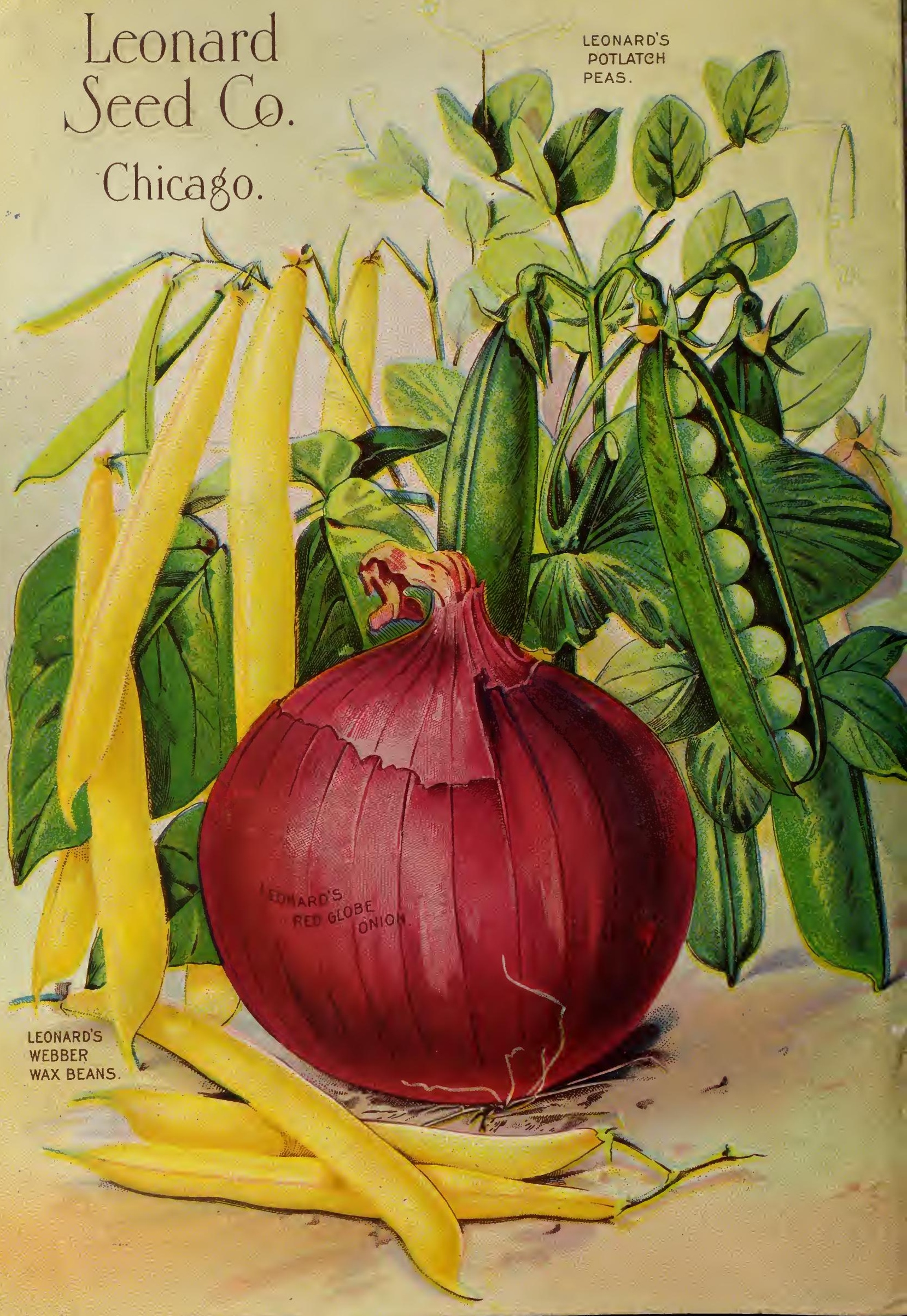

